\title{
Prenatal cadmium exposure dysregulates sonic hedgehog and Wnt/beta-catenin signaling in the thymus resulting in immunomodulatory effects
}

\author{
Miranda Leah Hanson \\ West Virginia University
}

Follow this and additional works at: https://researchrepository.wvu.edu/etd

\section{Recommended Citation}

Hanson, Miranda Leah, "Prenatal cadmium exposure dysregulates sonic hedgehog and Wnt/beta-catenin signaling in the thymus resulting in immunomodulatory effects" (2009). Graduate Theses, Dissertations, and Problem Reports. 4474.

https://researchrepository.wvu.edu/etd/4474

This Dissertation is protected by copyright and/or related rights. It has been brought to you by the The Research Repository @ WVU with permission from the rights-holder(s). You are free to use this Dissertation in any way that is permitted by the copyright and related rights legislation that applies to your use. For other uses you must obtain permission from the rights-holder(s) directly, unless additional rights are indicated by a Creative Commons license in the record and/ or on the work itself. This Dissertation has been accepted for inclusion in WVU Graduate Theses, Dissertations, and Problem Reports collection by an authorized administrator of The Research Repository @ WVU.

For more information, please contact researchrepository@mail.wvu.edu. 
Prenatal cadmium exposure dysregulates sonic hedgehog and Wnt/beta-catenin signaling in the thymus resulting in immunomodulatory effects

\author{
Miranda Leah Hanson \\ Dissertation submitted to the School of Medicine \\ at West Virginia University \\ in partial fulfillment of the requirements \\ for the degree of \\ Doctor of Philosophy \\ in \\ Immunology and Microbial Pathogenesis \\ John B. Barnett, Ph.D., Chair \\ Kathleen M. Brundage, Ph.D. \\ Peter H. Mathers, Ph.D. \\ Rosana Schafer, Ph.D. \\ Petia P. Simeonova, Ph.D.
}

Department of Microbiology, Immunology and Cell Biology

Morgantown, West Virginia

2009

Keywords: cadmium, prenatal, thymocyte development, sonic hedgehog, beta catenin 


\title{
ABSTRACT \\ Prenatal cadmium exposure dysregulates sonic hedgehog and Wnt/ $\beta$-catenin signaling in the thymus resulting in immunomodulatory effects
}

\author{
Miranda Leah Hanson
}

Cadmium (Cd) is both an environmental pollutant as well as a component of cigarette smoke. Recent data suggests increased cancer risks and increased mortality in environmentally exposed populations. Although evidence demonstrates that adult exposure to $\mathrm{Cd}$ causes changes in the immune system, there are limited reports in the literature of immunomodulatory effects of prenatal exposure to $\mathrm{Cd}$. The sonic hedgehog (Shh) and $\mathrm{Wnt} / \beta$-catenin pathways are required for thymocyte maturation. Several studies have demonstrated that Cd exposure affects these pathways in different organ systems. Our experiments were designed to investigate the effect of prenatal $\mathrm{Cd}$ exposure on thymocyte development, and to determine if these effects were linked to dysregulation of Shh and $\mathrm{Wnt} / \beta$-catenin pathways. In addition, longer term effects of prenatal $\mathrm{Cd}$ on the immune system were investigated. Pregnant $\mathrm{C} 57 \mathrm{BI} / 6$ mice were exposed to an environmentally relevant dose $(10 \mathrm{ppm})$ of $\mathrm{Cd}$ during pregnancy and effects on the thymus of the offspring were assessed on post-natal day 0 (PND0), while effects on the thymus and spleen were assessed on PND14 and 49. On PND0, thymocyte phenotype was determined by flow cytometry. A Gli:luciferase reporter cell line was used to measure Shh signaling. Transcription of target genes and translation of key components of both signaling pathways was assessed using real-time RT-PCR and western blot, respectively. On PND14 and 49, thymocyte and splenocyte phenotypes were analyzed, and cytokine production of splenic $T$ cells was determined by ELISA. On PND0, prenatal Cd exposure increased the number of $\mathrm{CD} 4^{+}$cells and a subpopulation of double-negative cells (DN; CD4 ${ }^{-} D 8^{-}$). Shh and $W n t / \beta$-catenin signaling were both decreased in the thymus; however, this was not due to altered Shh and Wnt protein levels. Target genes of Shh and Wnt/ $\beta$-catenin were affected differentially among thymocyte subpopulations. On PND14 and 49, prenatal Cd exposure increased the number of DN thymocytes. In the spleen, prenatal $\mathrm{Cd}$ exposure had a cell type-, sex-specific effect on splenocyte phenotype and cytokine production. Collectively, these findings suggest that even very low exposure to Cd during gestation dysregulates two signaling pathways in the thymus resulting in altered thymocyte development, and this dysregulation can result in long term detrimental effects on the immune system of the offspring. 


\section{LIST OF ABBREVIATIONS}

$\begin{array}{ll}\text { APC } & \text { Adenomatous polyposis coli } \\ \text { AXIN } & \text { Axis inhibitor } \\ \text { BMP } & \text { bone morphogenic protein } \\ \text { BOC } & \text { bioregional CDON binding protein } \\ \text { BRG } & \text { Brahma-related gene } \\ \beta \text {-TRCP } & \text { beta-transducin repeat containing protein } \\ \text { C } & \text { carboxyl-terminal } \\ \text { Ca } & \text { calcium } \\ \text { CBP } & \text { CREB-binding protein } \\ \text { CD } & \text { cluster of differentiation } \\ \text { CK } & \text { Casein kinase } \\ \text { Cl } & \text { chloride } \\ \text { CMJ } & \text { cortico-medullary junction } \\ \text { CREB } & \text { cyclic-AMP-responsive-element binding protein } \\ \text { cTEC } & \text { cortical thymic epithelial cell } \\ \text { Cu } & \text { Copper } \\ \text { DC } & \text { dendritic cell } \\ \text { Dhh } & \text { Desert hedgehog } \\ \text { Disp } & \text { Dispatched } \\ \text { DKK1 } & \text { Dikkopf-1 } \\ \text { DMT1 } & \text { divalent metal transport 1 } \\ \text { DN } & \text { double-negative } \\ \text { DP } & \text { double-positive } \\ \text { DVL } & \text { Dishevelled } \\ \text { E } & \text { embryonic day } \\ \text { E } & \text { Estradiol } \\ \text { ER } & \text { estrogen receptor, or endoplasmic reticulum } \\ \text { ERK } & \text { extracellular signal regulated kinase } \\ \text { Evi } & \text { Evenness interrupted } \\ \text { Fe } & \text { Iron } \\ \text { Fgf } & \text { fibroblast growth factor } \\ \text { Frizzled } & \text { Fz or FZD } \\ \text { FTOC } & \text { fetal thymic organ culture } \\ \text { GAS1 } & \text { growth arrest specific1 } \\ \text { GSH } & \text { Glutathione } \\ \text { GSK3 } & \text { glycogen synthase kinase 3 beta } \\ \text { h } & \text { Hour } \\ \text { HSC } & \text { hematopoietic stem cells } \\ \text { ICAT } & \text { Inhibitor of } \beta \text {-catenin } \\ \text { IFN- } \gamma & \text { inteferon-gamma } \\ & \end{array}$




$\begin{array}{ll}\text { IL } & \text { interleukin } \\ \text { ISP } & \text { immature single positive } \\ \text { kDa } & \text { kilodalton } \\ \text { LD } & \text { lethal dose } \\ \text { LEF } & \text { lymphoid enhancer factor } \\ \text { LGS } & \text { Legless } \\ \text { LRP } & \text { low density lipoprotein receptor-related protein } \\ \text { MHC } & \text { major histocompatibility complex } \\ \text { min } & \text { minute } \\ \text { MT } & \text { metallothionein } \\ \text { mTEC } & \text { medullary thymic epithelial cell } \\ \text { N } & \text { amino-terminal } \\ \text { NC } & \text { neural crest } \\ \text { NK } & \text { natural killer } \\ \text { NO } & \text { nitric oxide } \\ \text { PGE } 2 & \text { prostaglandin E2 } \\ \text { ppb } & \text { parts per billion } \\ \text { ppm } & \text { parts per million } \\ \text { Ptc/PTCH } & \text { Patched } \\ \text { Pygo } & \text { Pygopus } \\ \text { RAG } & \text { Recombination-activating gene } \\ \text { ROS } & \text { reactive oxygen species } \\ \text { SC } & \text { subcutaneous } \\ \text { SCID } & \text { severe combined immunodeficient } \\ \text { SCZ } & \text { subcapsular zone } \\ \text { Shh } & \text { Sonic hedgehog } \\ \text { Ski } & \text { Skinny hedgehog } \\ \text { Smo } & \text { Smoothened } \\ \text { SO } 4 & \text { sulfate } \\ \text { SP } & \text { single-positive } \\ \text { SUFU } & \text { Suppressor of fused } \\ \text { TCF } & \text { T-cell factor } \\ \text { TCR } & \text { T cell receptor } \\ \text { TEC } & \text { thymic epithelial cell } \\ \text { TGF } \beta & \text { Transforming growth factor beta } \\ \text { TLE } & \text { Transducin-like Enhancer of Split } \\ \text { TNF- } \alpha & \text { tumor necrosis factor-alpha } \\ \text { Wg } & \text { Wingless } \\ \text { Wls } & \text { Wntless } \\ \text { Zn } & \text { Wilms tumor suppressor } \\ & \end{array}$




\section{TABLE OF CONTENTS}

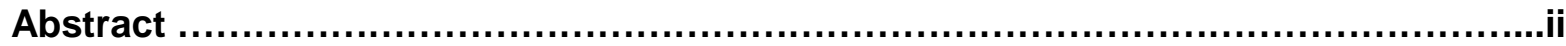

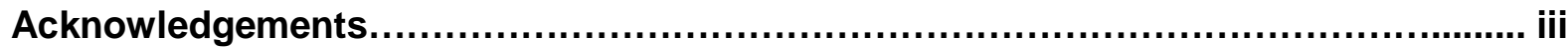

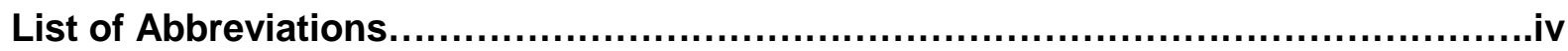

Chapter 1. Literature Review I..........................................................

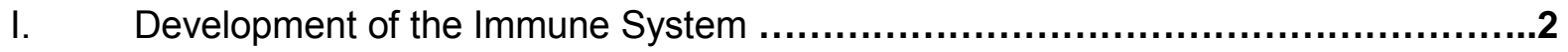

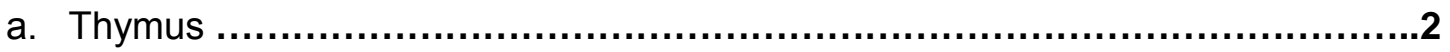

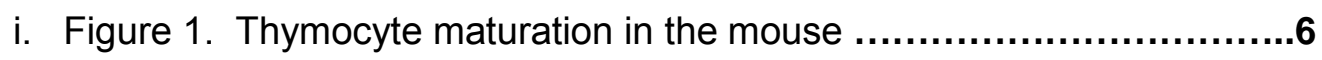

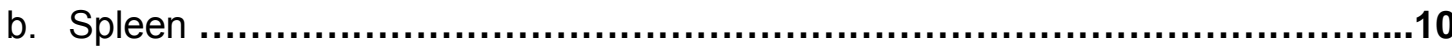

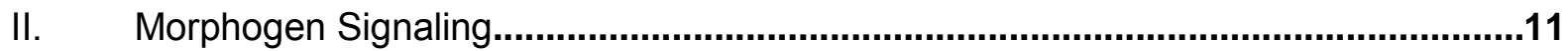

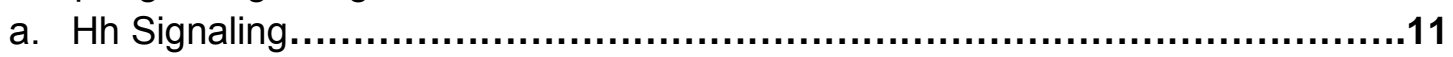

i. Table 1. Human genetic diseases caused by mutations in the Shh pathway................................................................................................12

ii. Figure 2. Shh processing and secretion...............................................13

iii. Figure 3. Hh signaling pathway...........................................15

iv. Figure 4. Role of morphogens in thymocyte development.....................17

b. Wnt Signaling..................................................................... 19

i. Figure 5. Wnt processing and secretion.....................................19

ii. Table 2. Human genetic diseases caused by mutations in the Wnt

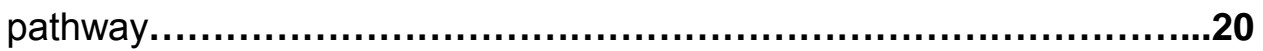

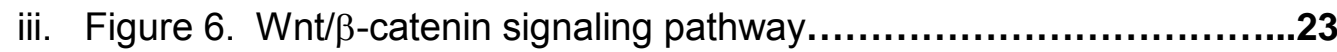

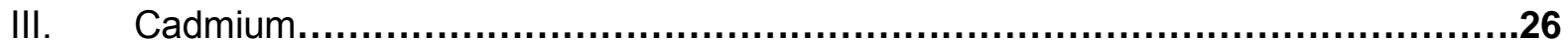

a. Human exposure.......................................................................26

i. Figure 7. Cadmium interacts with essential nutrients....................27

b. Absorption and excretion...........................................................28

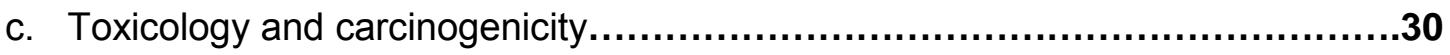

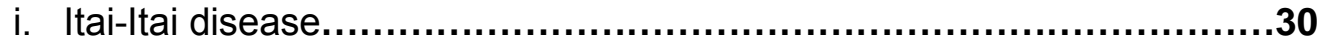

ii. Reproductive effects........................................................31

iii. Teratogenicity...................................................................

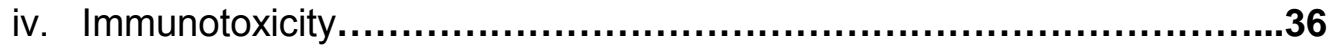

v. Carcinogenic effects....................................................42

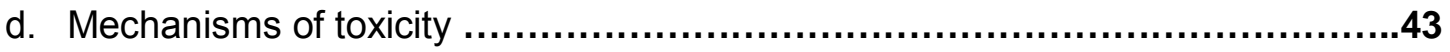

i. Oxidative stress.................................................................

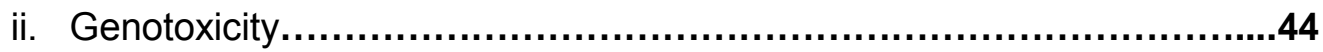

iii. Estrogenic effects..........................................................47

iv. Androgenic effects............................................................48

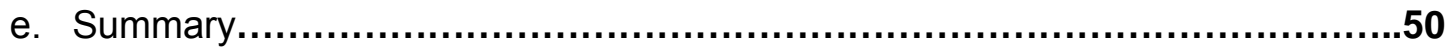

IV. References....................................................................... 51 
Chapter 2. Prenatal cadmium exposure dysregulates sonic hedgehog and Wnt/ $\beta$-catenin signaling in the thymus resulting in altered thymocyte development.....................101

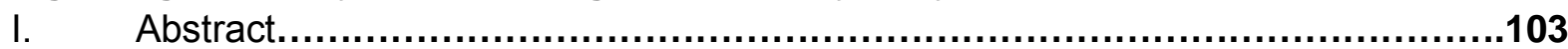

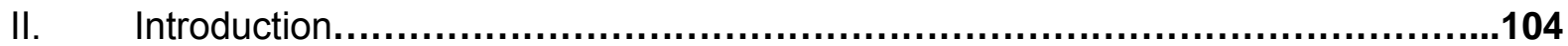

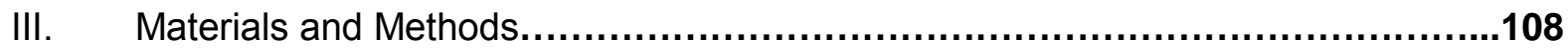

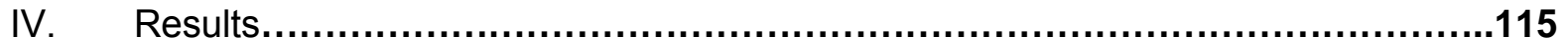

a. Figure 1. Thymocyte phenotype of PND0 offspring................................120

b. Figure 2. Shh signaling activity in thymic lysates of PNDO offspring...............122

c. Figure 3. Shh and Gli1 expression in thymic lysates of PND0 offspring...........124

d. Figure 4. Hh target gene expression in thymocyte subpopulations of PND0

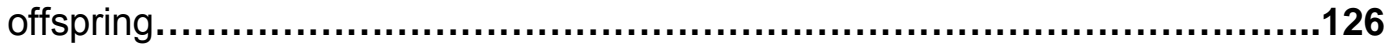

e. Figure 5. Active $\beta$-catenin and phospho- $\beta$-catenin expression in thymocytes of

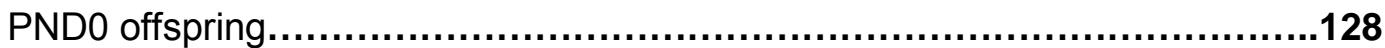

f. Figure 6. Wnt10b expression in thymus of PND0 offspring........................130

g. Figure 7. Wnt/ $\beta$-catenin target gene expression in thymocyte subpopulations of

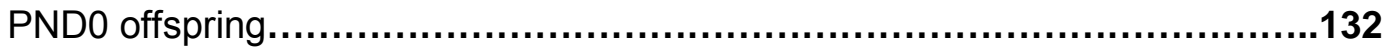

h. Figure 8. Proposed model for the effect of prenatal Cd exposure on Shh and Wnt/Bcatenin signaling in the thymus.....................................................134

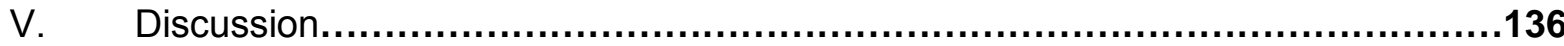

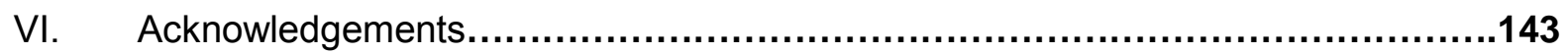

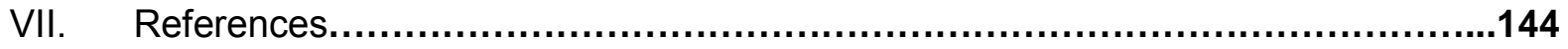

Chapter 3. Prenatal cadmium exposure alters postnatal immune cell development and

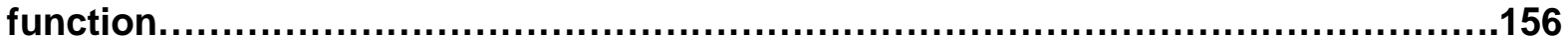

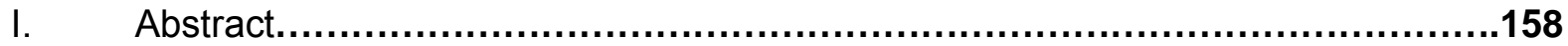

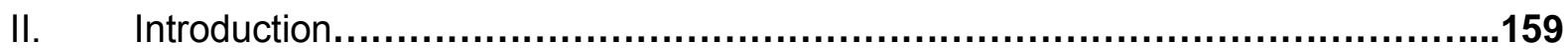

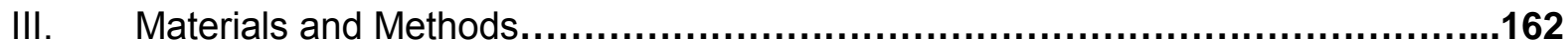

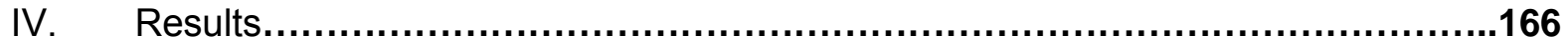

a. Figure 1. Thymocyte phenotype of PND14 and 49 offspring.......................170

b. Figure 2. Splenocyte phenotype of PND14 and 49 offspring........................172

c. Figure 3. Cytokine expression of splenic T cells on PND14 .........................174

d. Figure 4. Cytokine expression of splenic T cells on PND49........................176

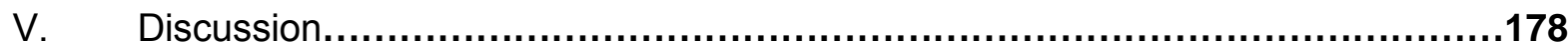

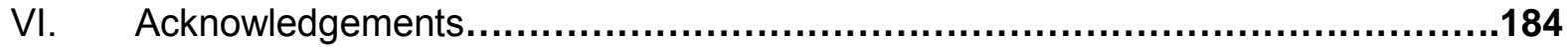

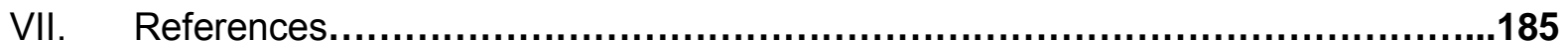

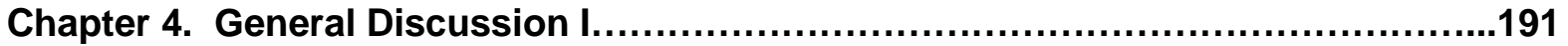

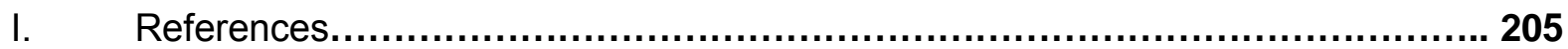

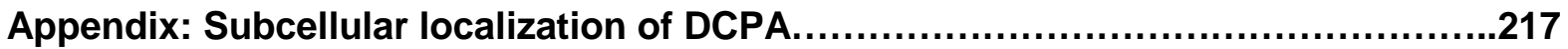

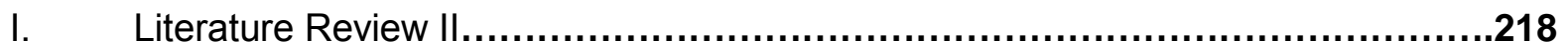

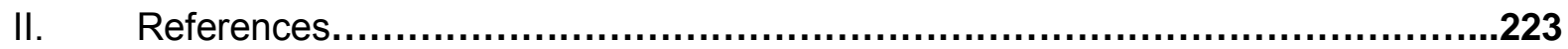

III. Subcellular localization of the amide class herbicide 3,4-dichloropropionanilide (DCPA)

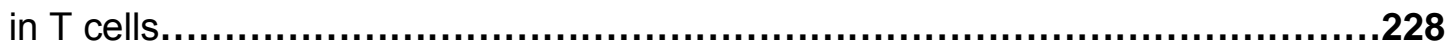




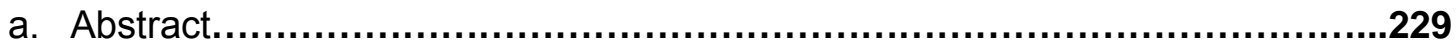

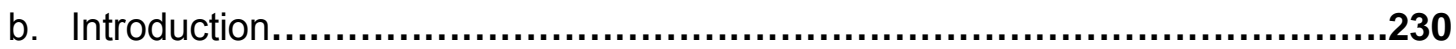

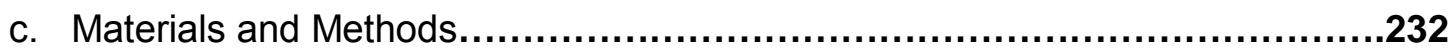

d. Results and Discussion.........................................................237

i. Figure 1. Chromatograms of DCPA localization on T cells................239

ii. Figure 2. Chromatograms of DCPA localization in hepatocytes..........241

iii. Table 1. DCPA concentration in T cell and hepatocyte fractions.........243

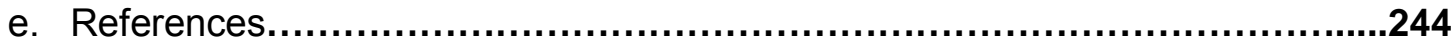

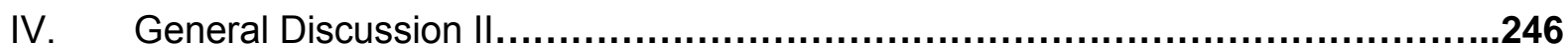

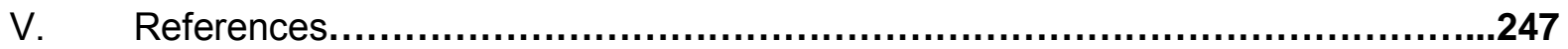

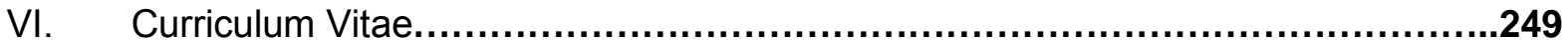


CHAPTER 1: Literature Review I 


\section{Development of the Immune System}

\section{Thymus}

The immune system originates from bone-marrow-resident hematopoietic stem cells (HSCs) that give rise to progenitor populations with increasingly restricted lineage potential, ultimately leading to production of all lineages of mature blood cells. The majority of hematopoietic lineages mature in the marrow, while the thymus is the primary lymphoid organ for T cell generation (Miller and Osoba, 1967). The thymus is the site of marrow-derived progenitors and is responsible for maintaining multistage lineage commitment and differentiation steps to produce mature, self-tolerant, functional T cells. Even though the thymus is a vital part of the hematopoietic system, the thymus does not contain self-renewing stem cells. In adults, the thymus is constantly being seeded from the bone marrow by small numbers of progenitor cells, which reach the thymus via the blood stream (Wallis et al., 1975) and enter the cortex-medulla boundary (Ceredig and Schreyer, 1984; Lind et al., 2001). The thymus is divided into an outer cortex, where most differentiation takes place, and an inner medulla, where newly formed cells undergo final maturation before exiting and seeding peripheral lymphoid organs (Scollay and Godfrey, 1995). The pattern of movement of developing thymocytes differs between the adult and fetal thymus, with progenitor cells entering the fetal thymus through the outside of the thymus rudiment (Suniara et al., 1999; Manley, 2000), and in the adult thymus through blood vessels in the medulla or perimedullary cortex (Lind et al., 2001; Petrie, 2003; Benz et al., 2004).

During murine embryogenesis, the thymus primordium is formed between embryonic day (E) 10.5 and E11.5 from the third pharyngeal pouch endoderm, which is 
a process that depends on interactions with the surrounding neural crest (NC)-derived mesenchyme. NC cells migrate from the dorsal portion of the neural tube during embryogenesis and contribute to a variety of neuronal and non-neuronal cell types. NC-derived mesenchyme is necessary for thymus organogenesis and thymus function (Manley, 2000; Owen et al., 2000; Anderson and Jenkinson, 2001; Petrie, 2002). The thymic epithelium is derived from the embryonic endodermal layer (Blackburn and Manley, 2004). Differentiation is dependent on and controlled by cellular interactions (Bockman, 1997). The roof of the endodermal yolk sac is folded into the expanding embryo as the foregut. The thymus rudiment begins to express Foxn1 at about E11.5. Foxn1 encodes a transcription factor whose function is essential for subsequent epithelial differentiation; without it, colonization of the rudiment by thymocyte progenitors fails (Bleul and Boehm, 2000), and thymopoiesis is aborted, resulting in severe immunodeficiency (Nehls et al., 1996). It is still unknown which signal(s) determine(s) the site and size of the thymic rudiment and whether these or other signals stimulate Foxn1 expression. Genetic abnormalities involving the formation of pharyngeal pouches, such as deficiencies in the transcriptional regulators, Tbx1, Pbx1, Eya1, and Six1, also have an impact on thymus formation (Manley et al., 2004; Arnold et al., 2006; Zou et al., 2006). Wnt and bone morphogenic protein (BMP) signals have also been implicated in initiating (Balciunaite et al., 2002) and/or maintaining (Bleul and Boehm, 2005; Patel et al., 2006) Foxn1 expression in the thymic epithelium.. During embryonic development, Sonic hedgehog (Shh) signaling is involved in restricting the size of the thymic field as measured by Foxn1 expression (Moore-Scott and Manley, 2005). 
At E12, the thymic rudiment is first colonized by lymphocyte progenitors (Jotereau et al., 1987), which enter through the capsule via a chemoattractive mechanism (Liu et al., 2006). At this point, the rudiment does not have histologically defined cortex and medulla regions that are present in the adult thymus. Rather, it contains mostly thymic epithelial cell (TEC) progenitors that subsequently undergo an ill-defined lineage commitment and differentiation program, resulting in distinct cortical and medullary TEC subsets, which are the major cells of the stroma (Rossi et al., 2006). The epithelial cells attract lymphoid precursor cells that are transported to this region through the bloodstream. By E13.5 in mice, the parathyroid and thymus are separated into physically distinct organs. Shortly following this, the thymus reaches its approximate adult position within the embryo. Other nonhematopoietic stromal elements, such as fibroblast and endothelial cells, and distinct hematopoietic-derived myeloid dendritic cells (DCs) and macrophages also contribute to the final thymic structure. Macrophages are distributed throughout the cortex and medulla where they are involved in phagocytosis of apoptotic cells (Surh and Sprent, 1994). DCs are predominately located in medullary regions, but they reach into cortico-medullary areas and have access to immature thymocytes (Kyewski et al., 1987; Shortman and Vremec, 1991; Surh and Sprent, 1994).

Thymus growth in the mouse takes place in two well defined periods: from E14 to E17-18, and from day 3 to day 6 after birth, as well as another less characteristic period from day 8 to day 14, when the thymus reaches its maximum, steady state size (Penit and Vasseur, 1989). The overall size of the thymus is probably determined by the action of p63 and fibroblast growth factor (Fgf) signaling through the Fgfr2IIlb receptor, 
with p63 acting upstream of Fgfr2 (Candi et al., 2007; Senoo et al., 2007). The thymic epithelium is necessary for T cell development which is demonstrated by the phenotype of nude mice, in which disruption of the transcription factor FoxN1 arrests TEC development at an immature progenitor stage and leads to loss of intrathymic $T$ cell development and severe immunodeficiency (Nehls et al., 1996; Su et al., 2003; Bleul et al., 2006). The specialized TEC subsets of the cortex and medulla facilitate distinct phases of $\mathrm{T}$ cell development. Thymocytes at different maturation stages occupy distinct regions in the adult thymus, implying that differentiation is coupled with the coordinated migration between microenvironments. Progenitors enter at the corticomedullary junction (CMJ), migrate through the cortex to the outer subcapsular zone (SCZ) during the early progenitor stages, and then move back toward the CMJ and into the medulla (Lind et al., 2001; Petrie and Zuniga-Pflucker, 2007). Cortical TECs (cTECs) support early $\mathrm{T}$ cell progenitor commitment and differentiation and play a primary role in $\beta$-selection and positive selection processes (Anderson et al., 1993; Anderson et al., 1994). Medullary TECs (mTECs), along with DCs, are needed for effective negative selection during the late stages of development (Derbinski et al., 2001; Gallegos and Bevan, 2004). There are multiple checkpoints during thymocyte maturation to limit the generation of cells having nonfunctional or autoreactive $\mathrm{T}$ cell receptor (TCR) complexes. $\alpha \beta$ T cell differentiation is characterized by CD4 and CD8 coreceptor expression (Figure 1). Lymphoid progenitor cells that seed the thymus are the immature $\mathrm{CD}^{-} \mathrm{CD} 8^{-}$double-negative (DN) precursor subset (Schmitt and ZunigaPflucker, 2005). The first checkpoint during thymocyte development is TCR $\beta$-selection which makes sure that only DN thymocytes that have generated a productively 
rearranged TCR $\beta$ chain are selected for further differentiation to the $C D 4^{+} \mathrm{CD} 8^{+}$doublepositive (DP) stage (Dudley et al., 1994; von Boehmer et al., 1999).

Figure 1. Thymocyte maturation in the mouse

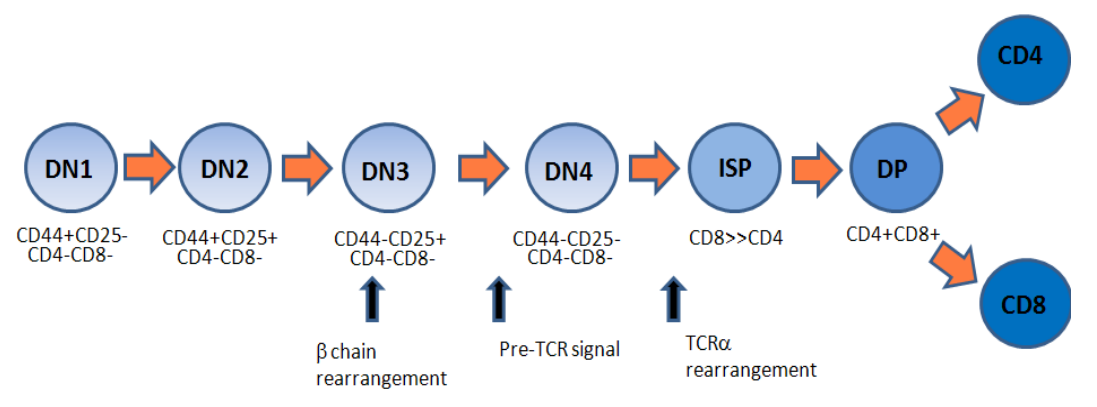

The second checkpoint takes place when DP cells go through positive and negative selection, allowing differentiation of MHC-restricted self-

tolerant mature CD4 and CD8 single positive (SP) T cells (Starr et al., 2003). In a mature thymus, $\sim 5 \%$ are DN cells, $\sim 80 \%$ are DP cells, $\sim 10 \%$ are $\mathrm{CD}^{+}$cells, and $\sim 5 \%$ are $\mathrm{CD} 8^{+}$cells (Ceredig et al., 1983). In the mouse, the DN population can be further subdivided into four sequential developmental subsets as follows: DN1

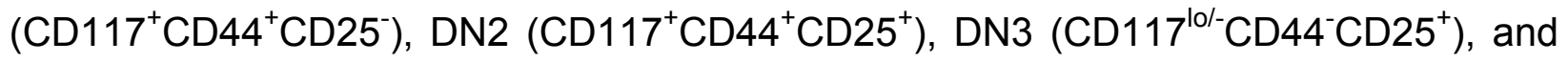
DN4 (CD117 CD44 $\left.{ }^{-} \mathrm{CD}^{-} 5^{-}\right)$(Godfrey et al., 1993). In the human thymus, CD34 ${ }^{+} \mathrm{CD}^{-} \mathrm{a}^{-}$ cells correspond to murine DN1 and DN2 thymocytes and $C D 34^{+} \mathrm{CD} 1 \mathrm{a}^{+}$cells are homologous to DN3 thymocytes (Dik et al., 2005). The DN1 cell population has multilineage potential, including B-cell, T-cell, myeloid cell, natural killer (NK)-cell and DC potential (Ardavin et al., 1993; Matsuzaki et al., 1993; Moore and Zlotnik, 1995; Shortman and Wu, 1996). The DN2 population lacks B-cell potential but still has NKcell and DC potential in addition to T cell potential (Wu et al., 1996; Schmitt et al., 2004). Final T-cell lineage commitment occurs at the DN3 stage when extensive rearrangement of TCR $\beta, \operatorname{TCR} \gamma$, and TCR $\delta$ loci occurs (Ismaili et al., 1996; Capone et al., 1998). DN3 cells with productive TCR $\beta$ rearrangements give rise to $\alpha \beta$-lineage DP 
cells that are short lived and the dominant T-lineage cell type in the adult mouse thymus (Huesmann et al., 1991). DN precursors give rise to two distinct T cell lineages, $\alpha \beta$ and $\gamma \delta$, however, the exact timing of when this occurs has not been determined. The TCR signal strength determines $\alpha \beta$ or $\gamma \delta$ lineage outcome (Haks et al., 2005; Hayes et al., 2005). Relatively weaker signals are associated with the pre-TCR, which is thought to signal autonomously, while stronger signals are associated with the $\gamma \delta$-TCR, possibly via ligand engagement (Irving et al., 1998; Yamasaki et al., 2006).

Recombination-activating gene (RAG) 1- and RAG2-mediated rearrangements of the TCR $\beta$, TCR $\gamma$, and TCR $\delta$ loci, which are needed for TCR assembly, are first detected in DN2 cells and continue predominantly during the mostly noncycling DN3 stage (Godfrey et al., 1994; Capone et al., 1998; Livak et al., 1999). Immature thymocytes expressing a functional TCR $\beta$ chain, which associates with the invariant pre-TCR $\alpha$ chain and CD3 signaling molecules to form the pre-TCR complex, are selected for $\alpha \beta$ lineage differentiation (Wu et al., 1996). The pre-TCR mediates the TCR $\beta$-selection event by signaling rescue from apoptosis, intensive cellular expansion, termination of TCR $\beta$ locus recombination, and differentiation to the DP stage (Dudley et al., 1994). In addition to the pre-TCR, signals from chemokines, interleukins, adhesion molecules, and Notch-receptor-ligand-interactions are necessary for differentiation from the DN3 stage to the DP stage (Misslitz et al., 2004; Radtke et al., 2004; Misslitz et al., 2006). In mice with gene deficiencies in Rag1, Rag2, or any component of the pre-TCR complex, severe arrest in $\alpha \beta$ T cell development at the DN3 stage occurs, thus demonstrating the critical role of pre-TCR formation (von Boehmer et al., 1999; Michie and ZunigaPflucker, 2002). During the pre-TCR-induced transition to the DP stage, selected cells 
downregulate CD25 and progress through a brief, intermediate immature CD8 single positive (ISP) stage.

Previous studies have established that proliferation is mostly associated with the DN and early DP populations (Scollay and Godfrey, 1995), therefore most cortical DP thymocytes are small nondividing cells. These cells have a finite lifespan of 3-4 days, but are able to undergo positive selection and differentiation into $\mathrm{CD} 4^{+}$or $\mathrm{CD}^{+}$cells (Lundberg and Shortman, 1994; Swat et al., 1994). Continued TCR $\alpha$ chain gene rearrangement has been demonstrated in the DP population, increasing chances of positive selection (Petrie et al., 1993). In regards to proliferation of the DN population, studies have shown that cells that are mostly nondividing following entry into the thymus undergo two phases of proliferation separated by a stable period at the DN3 stage (Penit et al., 1995).

Interactions between thymocytes and stromal cells are essential for the development of both $\mathrm{T}$ cell precursors and the thymic stroma. A study in which severe combined immunodeficient (SCID) mice displayed an absence of mTECs until the introduction of normal bone marrow, at which point regeneration of mTECs occurred, demonstrated that development of the thymic medulla is dependent upon the presence of thymocytes (Shores et al., 1991). In addition, absence of medullary areas has been noted in TCR $\alpha$-deficient mice (Palmer et al., 1993). The importance of the thymocytestromal interaction is also evident in positive and negative selection. Two-photon imaging studies of thymocyte behavior showed longer dwell times of thymocytes in a positively selecting environment, indicating that, similar to mature $T$ cells, thymocytes require sustained interactions with their environment for the delivery of selection signals 
(Bousso and Robey, 2004). In general, most negative selection occurs in the medulla once the thymocyte has been positively selected and chosen to commit to the CD4 or CD8 lineage. Negative selection depends on tissue-specific antigen expression by the transcription factor Aire as well as mTEC integrity (Anderson et al., 2002; Kajiura et al., 2004; Akiyama et al., 2005; Kinoshita et al., 2006). The chemokine CCR7 has been shown to be necessary for the migration of the developing thymocyte from the cortex to the medulla (Ueno et al., 2004), and this migration is needed for the establishment of self-tolerance (Kurobe et al., 2006).

Many studies have implicated transcription factors, cytokines, growth factor receptors, signaling molecules, and extracellular matrix molecules as playing important roles in thymocyte maturation, including Wnt molecules, Hh molecules, and FGFs (Staal and Clevers, 2003; Rowbotham et al., 2007b). Also, roles for BMPs and the TGF- $\beta$ superfamily have been implicated in thymocyte development, mostly for their ability to influence FGF and Wnt-stimulated signals (Tsai et al., 2003; Licona-Limon and Soldevila, 2007).

During the neonatal and early postnatal stages of development, the immune response varies greatly from that of a fully developed adult. One of the major differences is that neonatal $\mathrm{T}$ cells have poor cytokine production in comparison to the adult (Bryson et al., 1981) particularly in relation to Th1 cytokines. The underlying mechanisms that account for this deficiency are not fully understood, but appear to derive partly from the secretory functions of the placenta (Wegmann et al., 1993). The relatively poor capacity of neonatal $\mathrm{T}$ cells to produce cytokines is considered to contribute to the impaired responses of other neonatal cell populations that depend on 
these factors for their functions, e.g. poor IFN- $\gamma$ production could help to reduce cellular cytotoxicity by NK cells (Yabuhara et al., 1990), and reduced IL-4 has a role in reduced IgE production by neonatal B cells (Pastorelli et al., 1990).

\section{Spleen}

Splenic development in the mouse begins at E11.5, and at E12.5, it is detectable by the condensation and proliferation of $\mathrm{Hox} 11^{+}$mesenchymal cells as a ridge attached to the dorsal area of the stomach (Roberts et al., 1994). The first hematopoietic cells to populate the mouse spleen appear at around E15.5. Spleen development depends on Hox $11^{+}$and in mice lacking this homeobox gene, development of the splenic rudiment begins normally but development arrests between E12.5-13.5, prior to colonization by hematopoietic cells (Roberts et al., 1994). Critical roles in spleen development have also been identified for the transcription factors Wilms tumor suppressor (wt1), Bapx1, and capsulin. Mice lacking the wt1 gene die during late gestation (Herzer et al., 1999). Analysis of wt1-deficient embryos demonstrated that the spleen rudiment formed at E11-12 but involuted by E15 (Herzer et al., 1999). Bapx1 deficiency also results in a variety of developmental defects and is associated with perinatal lethality. Analysis at E11.5 showed that the spleen rudiment failed to form and Hox11 expression could not be detected, suggesting a very early role for Bapx1 (Tribioli and Lufkin, 1999; Lettice et al., 2001). Capsulin-deficient mice also die perinatally (Lu et al., 2000). Capsulin expression was detected within the undifferentiated mesoderm corresponding to the embryonic origin of the spleen in the dorso-lateral wall of the stomach (Lu et al., 2000). 


\section{Morphogen Signaling}

Thymocyte development and T-cell lineage commitment are influenced by the mammalian homologues of many protein families that were first identified as developmental regulators of Drosophila, including Notch (Radtke et al., 1999; Radtke et al., 2004; Guidos, 2006), Wnt (Verbeek et al., 1995; Schilham et al., 1998; Mulroy et al., 2002), BMP (Graf et al., 2002; Hager-Theodorides et al., 2002; Tsai et al., 2003; Cejalvo et al., 2007), and Hh family of proteins (Outram et al., 2000; Sacedon et al., 2003; Shah et al., 2004). The $\mathrm{Hh}$ and Wnt family proteins, and the BMPs, act as morphogens during vertebrate embryogenesis and organogenesis by regulating patterning and cell fate. Morphogens are secreted signaling molecules produced at a localized source that specify cell fate in a concentration-dependent manner.

\section{Hh signaling}

The Hh family of secreted proteins is comprised of intercellular signaling molecules that specify cell fate and patterning during the development of many tissues. In mammals, there are three $\mathrm{Hh}$ family members, Sonic hedgehog (Shh), Indian hedgehog (Ihh), and Desert hedgehog (Dhh) (Ingham and McMahon, 2001), of which Shh is the best studied. Shh ${ }^{-/-}$animals have a multitude of defects including cyclopia, poor neural patterning, lack of limb growth, and abnormal organ and foregut development (Ingham and McMahon, 2001). In addition, a variety of diseases and malformations can occur when other genes of the Shh signaling pathway are mutated (Wynshaw-Boris, 2006) (Table 1). In general, the processing and signaling of Hh family 
Table 1. Human genetic diseases caused by mutations in the Shh pathway

\begin{tabular}{|l|l|l|}
\hline Gene mutated & Disease & Manifestations \\
\hline SHH & Holoprosencephaly & $\begin{array}{l}\text { Variable midline defects } \\
\text { (single maxillary incisor, } \\
\text { hypotelorism, } \\
\text { holoprosencephaly, cyclopia) }\end{array}$ \\
\hline PTCH-1 & Gorlin syndrome & $\begin{array}{l}\text { Dysmorphic syndrome (short } \\
\text { metacarpals, rib defects, } \\
\text { broad face, dental } \\
\text { abnormalities), cancer } \\
\text { predisposition } \\
\text { (rhabdomyosarcoma, } \\
\text { medulloblastoma) }\end{array}$ \\
\hline PTCH-1 or -2 & Cancer & $\begin{array}{l}\text { Basal cell carcinomas, } \\
\text { medulloblastomas }\end{array}$ \\
\hline SMO & Cancer & $\begin{array}{l}\text { Basal cell carcinomas, } \\
\text { medulloblastomas }\end{array}$ \\
\hline GLI1 & Cancer & $\begin{array}{l}\text { Glioblastoma, osteosarcoma, } \\
\text { rhabdomyosarcoma, B cell } \\
\text { lymphomas }\end{array}$ \\
\hline GLI3 & Pallister-Hall syndrome & $\begin{array}{l}\text { Hypertelorism, syndactyly, } \\
\text { preaxial polydactyly }\end{array}$ \\
& Greig syndrome & $\begin{array}{l}\text { Postaxial polydactyly, } \\
\text { syndactyly, hypothalamic } \\
\text { hamartomas }\end{array}$ \\
\hline
\end{tabular}

Adapted from Wynshaw-Boris (2006)

members is similar across the various mammalian paralogs and is also evolutionary conserved. Hh is initially synthesized as a preprotein, which subsequently enters the secretory pathway where the signal sequence is removed to yield an approximately 45 kDa precursor protein (Ingham and McMahon, 2001; Torroja et al., 2005) (Figure 2). The precursor protein undergoes an intramolecular cleavage reaction to generate a 19 kDa amino-terminal polypeptide (Hh-N) and a carboxyl-terminal polypeptide (Hh-C) (Lee et al., 1994; Bumcrot et al., 1995). During this cleavage, cholesterol is covalently attached to the C-terminus of the Hh-Np ( $\mathrm{p}$ for processed) (Porter et al., 1995). This cleavage takes place in an undefined intracellular compartment. Hh is the only known secreted ligand that is covalently modified by cholesterol. It is likely that this unique 
modification results in many of the unusual biological mechanisms that have been described in the Hh pathway. A palmitoyl acid is also added to the N-terminus of Shh-N (Pepinsky et al., 1998). This palmitoylation is catalyzed by the membrane bound $O-$ acyltransferase commonly known as Skinny Hh (Ski) (Mann and Beachy, 2004; Torroja et al., 2005). Animals lacking Ski function exhibit phenotypes resembling $\mathrm{Hh}^{-/}$animals, demonstrating the importance of palmitoylation for transduction of the $\mathrm{Hh}$ signal (Pepinsky et al., 1998; Chamoun et al., 2001; Chen et al., 2004). The majority of Hh found in vivo appears to be modified by both cholesterol and palmitate (Pepinsky et al., 1998; Chamoun et al., 2001). The lipid modifications serve an important role in

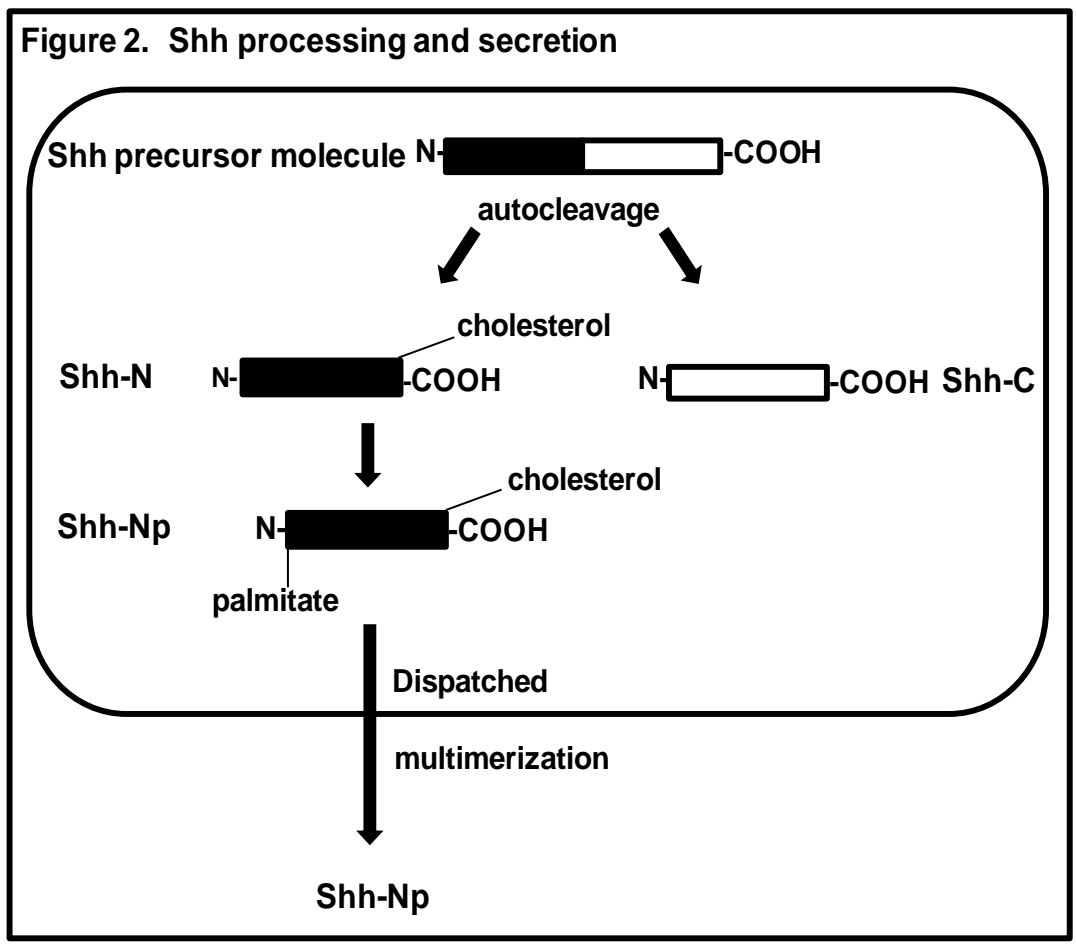

regulating $\mathrm{Hh}$ localization and activity. The dually lipidated protein is then secreted from the Shhproducing cell by the 12pass membrane protein Dispatched (Disp) (Burke et al., 1999). $\mathrm{Hh}$ processing occurs normally in Disp ${ }^{-/-}$cells, but it is unable to efficiently leave the cell (Ingham and McMahon, 2001; Torroja et al., 2005). Complete loss of Disp function leads to strong Hh loss of function phenotypes, indicating a positive role for Disp in Hh signaling (Torroja et al., 2005; Guerrero and Chiang, 2007). The dually modified $\mathrm{Hh}$ is secreted as a multimeric form (Zeng et al., 
2001; Chen et al., 2004; Gallet et al., 2006). Formation of multimeric Hh allows the normally hydrophobic $\mathrm{Hh}-\mathrm{Np}$ to transmit a signal far from its site of synthesis, as disruption of these multimeric $\mathrm{Hh}$ structures results in loss of long-range $\mathrm{Hh}$ signaling (Chen et al., 2004; Gallet et al., 2006).

Shh and Ihh are both expressed in the thymus. Shh is produced by the thymic epithelium, and Ihh expression is mainly associated with blood vessels in the medulla (Outram et al., 2000), and more recently has been shown to be produced by DP cells (Outram et al., 2008). Each of the Hh proteins has different expression patterns and essential nonredundant roles during embryogenesis, but do share a common signaling pathway (Figure 3). They bind to their surface receptor Patched (Ptc), in order to signal to neighboring cells (Marigo et al., 1996; Stone, 1996). There are two Patched isoforms, Ptc1 and Ptc2. The mouse and zebrafish homologues of Ptc2 have been reported to be expressed in a partly overlapping pattern with Ptc1 during embryonic development and to be induced by Shh (Concordet et al., 1996; Motoyama et al., 1998). Tissue distribution analysis indicates that Ptc2 is preferentially expressed in the skin and in the testis, where it is likely to mediate the action of Dhh, which is required for germ cell development (Carpenter, 1998). Ptc2 is expressed in the thymus, but its expression is restricted to $\mathrm{CD} 34^{+}$thymic progenitor cells and cortical and medullary cytokeratin-positive epithelial cells (Sacedon et al., 2003). Ptc2 is generally weaker than Ptc1 in its tumor-suppressor ability (Carpenter, 1998). When Hh is present, Ptc (both isoforms) releases its suppression of the cell surface molecule Smoothened (Smo), enabling the Hh signal to be transmitted into the target cell (van den Heuvel and Ingham, 1996) (Figure 3). This transduction is regulated by complex interactions and 
modifications of many cytoplasmic proteins ultimately resulting in the activation of members of the Gli family of zinc finger transcription factors (Gli 1-3) (Ingham and McMahon, 2001). When Hh protein is absent, Ptc inhibits the ability of Smo to signal (Chen and Struhl, 1998; Taipale et al., 2002). Gli1 is an activator of transcription whereas Gli2 and Gli3 probably function both as positive and negative regulators of transcription (Koebernick and Pieler, 2002). Gli1 and Gli2 transcription is positively regulated by $\mathrm{Hh}$ signaling, while Gli3 transcription is downregulated by $\mathrm{Hh}$ (Ruiz $\mathrm{i}$ Altaba, 1999). Gli1 is not required to initiate the $\mathrm{Hh}$ signal and is itself a target gene of the Hh pathway, so measurement of its transcription can be used as a read-out of $\mathrm{Hh}$ signaling in a population of cells. When Hh signaling is absent, Gli2 and Gli3 undergo modification by phosphorylation and cleavage of their

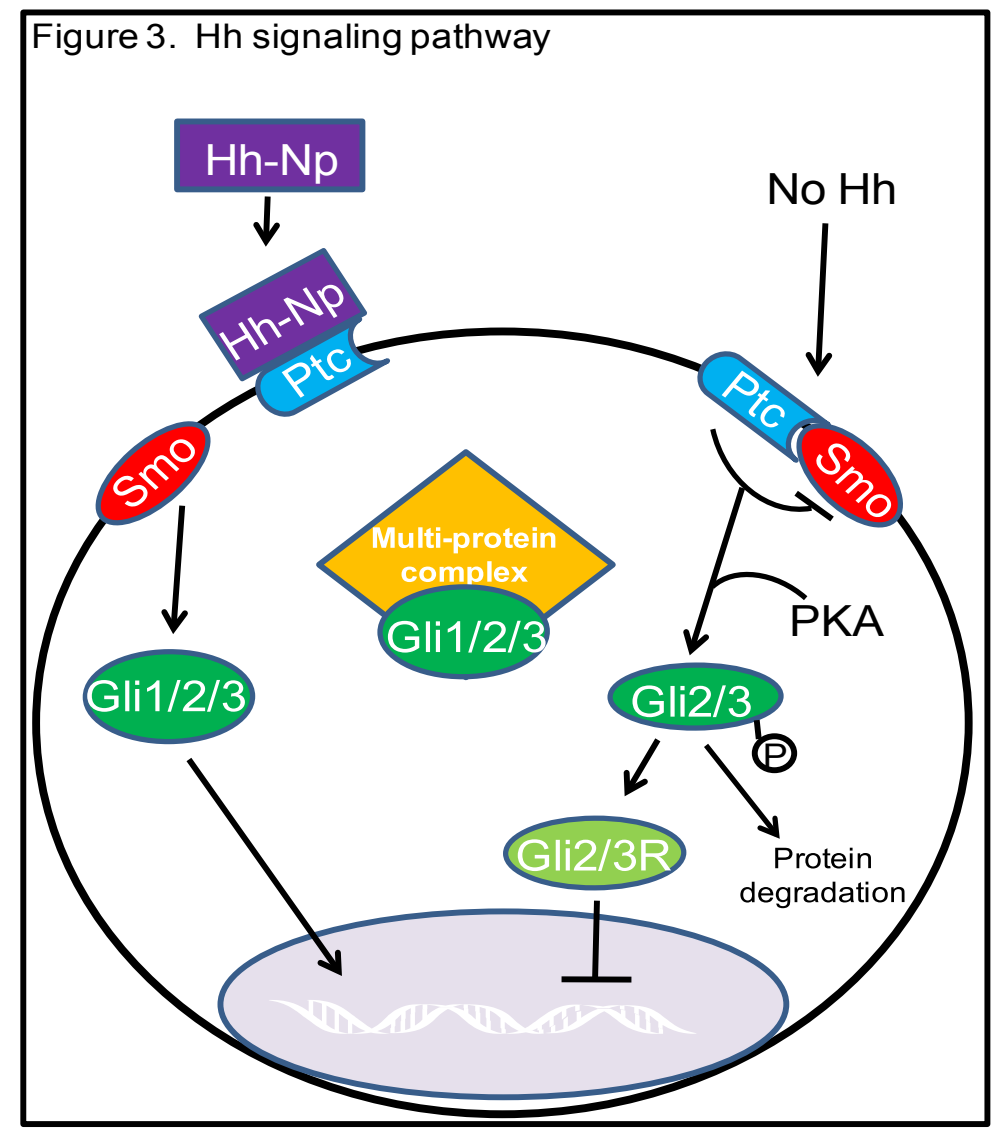

transactivation domain so that they function as repressors of target gene transcription (Matise and Joyner, 1999; Koebernick and Pieler, 2002). Further regulation of Gli protein activity is mediated by sequestration of Gli proteins in the cytoplasm by a multiprotein complex that contains suppressor of fused (SUFU), which acts as a negative regulator of the Hh pathway, by 
preventing nuclear accumulation of Gli1 and Gli2 (Barnfield et al., 2005). Gli2 and Gli3 are each essential for mouse development and have unique, as well as partially overlapping functions (Mo et al., 1997). Although Gli2 and Gli3 are bifunctional, Gli2 has been reported to act in vivo as a transcriptional activator, while Gli3 mainly functions as a transcriptional repressor (Wang et al., 2000; Bai et al., 2002).

Several factors that influence the response of a cell to the signal received include Hh concentration and length of exposure to the signal (Stamataki et al., 2005). The presence of cell-surface molecules such as CDO (cell-adhesion-moleculerelated/downregulated by oncogenes; also called CDON), BOC (bioregional CDON binding protein) and GAS1 (growth-arrest-specific 1) enhances Shh signaling (Tenzen et al., 2006; Allen et al., 2007). In addition, cells can migrate in and out of range of the Hh signal. Cells near the source of $\mathrm{Hh}$ secretion can modulate the range of the signal by upregulating their expression of Ptc1, which can sequester Hh and thereby prevent it from spreading further (Chen and Struhl, 1996).

Components of the Hh signaling pathway, including Shh, Ihh, Ptc, Smo, Gli1, Gli2, and Gli3 are expressed in the murine thymus in both the adult and the fetus (Outram et al., 2000; Li et al., 2002a; Li et al., 2002b). Immunohistochemical studies have located Shh production to epithelial cells scattered in the subcapsular region and in the medulla and cortico-medullary junction of both mice and human thymi (Outram et al., 2000; Sacedon et al., 2003; Shah et al., 2004; Andaloussi et al., 2006; Virts et al., 2006). Cell-surface expression of the signal transduction molecule Smo is mostly restricted to DN thymocytes and is downregulated on the subsequent DP and CD4 ${ }^{+}$and $\mathrm{CD}^{+}$populations. Analysis of DN populations showed that the DN1 cells that are not 
committed to the T-cell lineage (Haks et al., 1999) do not express significant levels of Smo (Outram et al., 2000). In DN2 cells, Smo expression is upregulated, but then decreases in the DN3 and DN4 populations, and is then almost undetectable in DP populations (Outram et al., 2000; Andaloussi et al., 2006). Smo expression is then upregulated on SP, with expression on $9 \%$ of $\mathrm{CD}^{+}$cells and $20 \%$ of $\mathrm{CD}^{+}$cells (Outram et al., 2000). This expression pattern suggests that the thymocytes that are responding to the $\mathrm{Hh}$ signal are the DN cells and a proportion of SP cells.

Analysis of fetal thymocyte development in Shh-and Gli3-deficient embryos has demonstrated that Shh provides a positive signal for thymocyte differentiation and proliferation at the DN1 to DN2 transition (Shah et al., 2004; Hager-Theodorides et al., 2005) (Figure 4). Thymi from $\mathrm{Shh}^{-/}$mice contained approximately 10 times fewer thymocytes than thymi from control littermates, and had reduced thymocyte proliferation and a partial arrest in development at the DN1 stage (Shah et al., 2004). There was a partial thymocyte block at the DN1 stage in $\mathrm{Gli}^{-/-}$thymi, but thymocyte number and proliferation was unaffected, suggesting that Gli3 is downstream of Shh in signaling for

Figure 4. Role of morphogens in thymocyte development

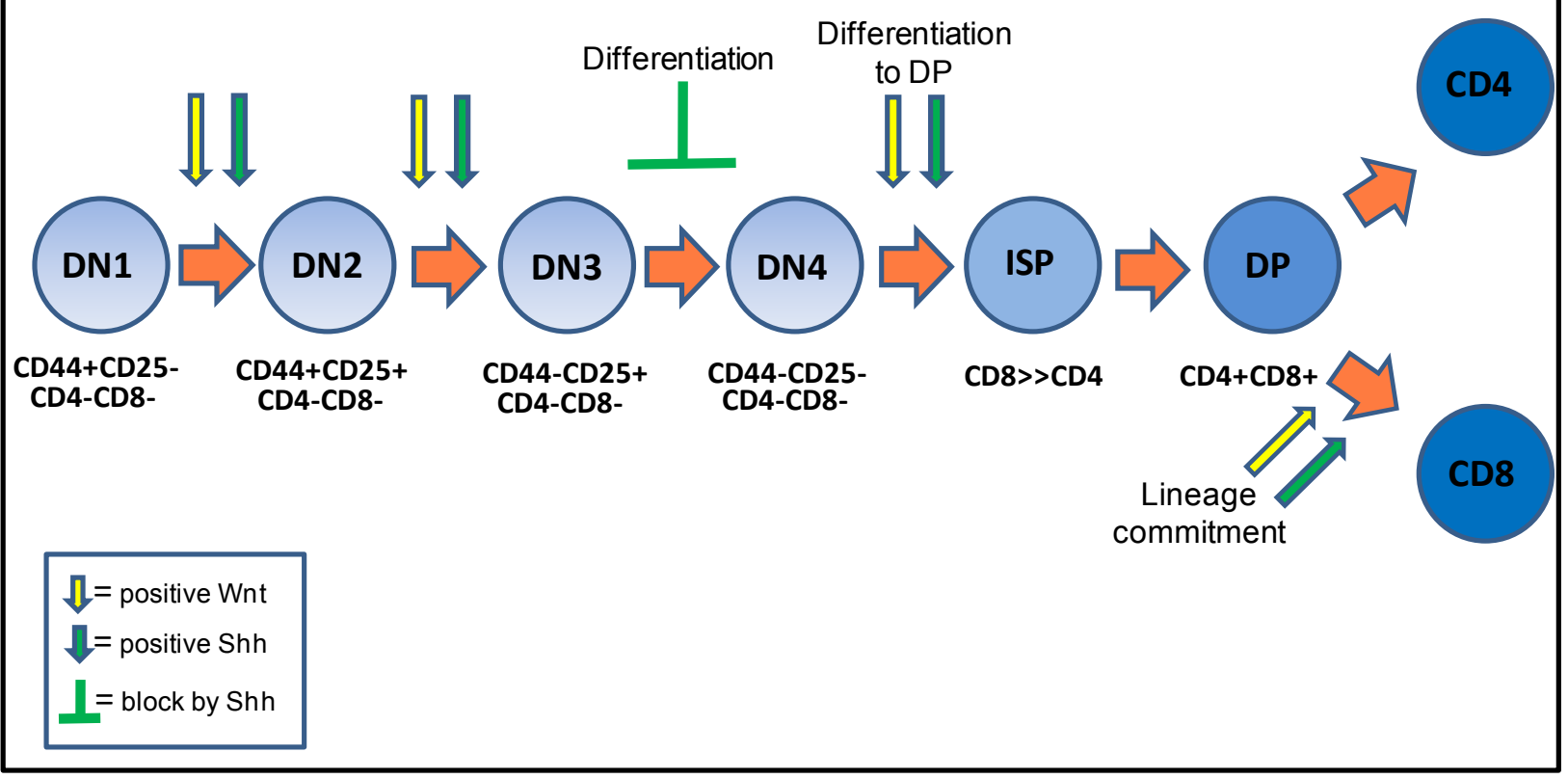


differentiation only (Hager-Theodorides et al., 2005). Using Smo knockouts, a role of Shh signaling in differentiation of early DN cells in adult thymi has been established (Andaloussi et al., 2006). Specifically, Shh signaling is critical for DN1 to differentiate to the DN2 stage. Analysis of Shh ${ }^{-/}$mouse embryos has suggested that Shh influences very early thymocyte development prior to the DN1 to DN2 transition (Shah et al., 2004). The Shh" thymi of mice on embryonic day 13.5 were smaller and contained a reduced proportion of cells of hematopoietic origin, suggesting that Shh is necessary for their development either before or during entry of thymocyte progenitors to the thymus (Shah et al., 2004). The function of Hh signaling at the transition from DN to DP cells is controversial due to conflicting data which suggests that Hh can have a positive role (Shah et al., 2004), a negative role (Outram et al., 2000), or no role at all during this transition (Andaloussi et al., 2006). The most likely model is one that takes all data into account, in which Shh signals positively for thymocyte development prior to pre-TCR transduction, but acts as an inhibitor from the DN3 to DP transition after the pre-TCR signal (Crompton et al., 2007). Since Shh is a morphogen, it produces certain outcomes depending on the concentration and duration of the signal received, as well as the competence of the signal-receiving cell, so it is possible that Shh can act as either a positive or negative regulator based upon its concentration. For example, in $\mathrm{Shh}^{-1-}$ fetal thymic organ cultures (FTOC), treatment with low-dose recombinant Shh increased DP cell production, while treatment with higher concentrations of recombinant Shh arrested differentiation (Shah et al., 2004).

Activation of the Shh signaling pathway in developing thymocytes influences TCR repertoire selection and the differentiation from DP to SP cells by influencing the 
strength of the TCR signal through a mechanism upstream of extracellular-signalregulated kinase (ERK) activation (Rowbotham et al., 2007a). In Shh ${ }^{-/}$FTOCs, the ratio of mature $\mathrm{CD} 4^{+}$to $\mathrm{CD}^{+}$cells was increased, which is consistent with an increase in TCR-signal strength during positive selection (Rowbotham et al., 2007a). When wildtype E17.5 FTOCs were treated with recombinant Shh, the ratio of mature CD4 ${ }^{+}$to $\mathrm{CD}^{+}$cells was decreased (Rowbotham et al., 2007a). In summation, studies on Shh's role in the thymus demonstrate the necessity of Shh in thymocyte development and T cell activation.

\section{Wnt signaling}

The Wnt pathway derives its name from the Drosophila Wingless gene and the mouse INT-1 gene. Wnt genes encode a large family of secreted glycoproteins

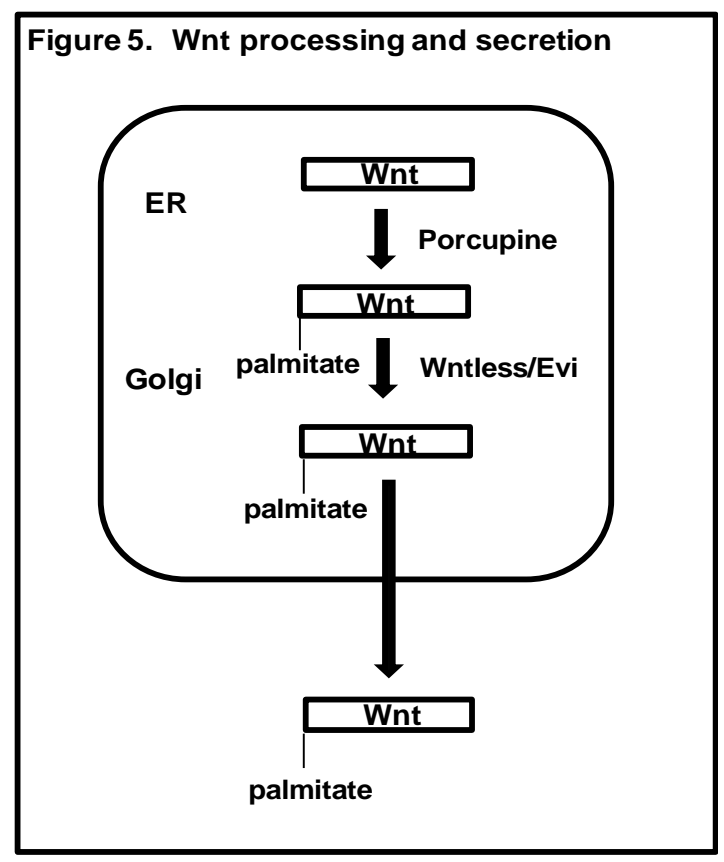

that are involved in a variety of cell activities in development (Miller, 2002). The importance of this pathway is quite evident, as mutations in the Wnt pathway or its components can result in a variety of diseases (Logan and Nusse, 2004) (Table 2). In humans, 19 WNT genes have been identified and the chromosomal locations of each are known (Coudreuse and Korswagen, 2007). With a few exceptions

(Wg, Wnt3/5, and Wnt4), Wnt proteins are usually around 350 amino acids long and have an approximate molecular weight of $40 \mathrm{kDa}$ (Miller, 2002). Wnts begin as precursors containing an $\mathrm{N}$-terminal hydrophobic signal peptide that directs the 
immature protein to the endoplasmic reticulum (ER) (Figure 5). In the ER, the signal peptide is cleaved by a protease and the Wnt protein is modified by addition of sugars and lipids by the acyl-transferase porcupine in order for proper secretion to occur. The attachment of a palmitate moiety to a conserved cysteine residue on the Wnts, which convert them into hydrophobic proteins, is essential for their biological activity (Willert et al., 2003; Zhai et al., 2004). Transport and secretion of the Wnt protein in secretory vesicles is controlled by the multi-pass transmembrane protein Wntless (Wls)/Evenness interrupted (Evi) (Ching and Nusse, 2006).

Table 2. Human genetic diseases caused by mutations in the Wnt pathway

\begin{tabular}{|l|l|l|}
\hline Gene mutated & Disease & Manifestations \\
\hline Wnt3 & Tetra-amelia & Absence of limbs \\
\hline LRP5 & $\begin{array}{l}\text { Osteoporosis-pseudoglioma } \\
\text { syndrome, familial exudative } \\
\text { vitroretinopathy }\end{array}$ & $\begin{array}{l}\text { Bone density defects, Retinal } \\
\text { angiogenesis defects }\end{array}$ \\
\hline FZD4 & $\begin{array}{l}\text { Familial exudative } \\
\text { vitroretinopathy }\end{array}$ & Retinal angiogenesis defects \\
\hline Axin2 & $\begin{array}{l}\text { Tooth agenesis, } \\
\text { predisposition to colorectal } \\
\text { cancer }\end{array}$ & $\begin{array}{l}\text { Absence of multiple } \\
\text { permanent teeth }\end{array}$ \\
\hline APC & Polyposis coli, colon cancer & Polyps in colon and rectum \\
\hline
\end{tabular}

Wnt signals are transduced through at least three different signaling pathways; however, the canonical $\beta$-catenin/T-cell factor-lymphoid enhancer factor (TCF-LEF) primarily functions during thymocyte development (Figure 6). The canonical pathway is stimulated by Wnt proteins that bind to cell surface Frizzled (Fz) receptors and the coreceptor low density lipoprotein receptor-related protein 5 (LRP5) or LRP6 (Bhanot et al., 1996). Signaling through Fz receptors following Wnt binding results in the stabilization of $\beta$-catenin (Behrens et al., 1996). $\beta$-catenin is a multifunctional protein 
that enters the nucleus, engages with LEF-1 and the TCFs, TCF1, TCF3, TCF4, and functions as a transcription factor (Novak and Dedhar, 1999). TCF and LEF are transcription factors that are bound to DNA and, in the absence of $\beta$-catenin, interact with transcriptional corepressors, such as Groucho, which inhibits transcription (Roose et al., 1998). Other proteins in the nucleus that control Wnt signaling events include Chibby, which is a nuclear antagonist that binds to the C-terminus of $\beta$-catenin (Takemaru et al., 2003), and Inhibitor of $\beta$-catenin and TCF (ICAT) (Tago et al., 2000), which blocks the binding of $\beta$-catenin to TCF (Tago et al., 2000), but also leads to dissociation of $\beta$-catenin and LEF complexes (Daniels and Weis, 2005). Activation of the Wnt target gene program is achieved when $\beta$-catenin displaces the Groucho/Transducin-like Enhancer of Split (TLE) corepressor proteins from Tcf (Daniels and Weis, 2005) and efficiently recruits a variety of proteins capable of effecting changes in local chromatin structure to the Wnt target genes (Stadeli et al., 2006). Many of these co-activator proteins, such as the histone acetylase cyclic-AMP-responsiveelement binding protein (CREB)-binding protein (CBP), Brahma-related gene (BRG)-1, and Hyrax interact directly with the C-terminus of $\beta$-catenin. Another protein, Pygopus, indirectly binds the $\mathrm{N}$-terminus of $\beta$-catenin via a common binding partner, Bcl9 (legless in Drosophila). The exact role of the $\beta$-catenin/Bcl9/Pygopus complex is controversial, in that one line of evidence suggests that it facilitates the nuclear import/retention of $\beta$ catenin (Townsley et al., 2004), while another study supports a direct role for the complex in enhancing the ability of $\beta$-catenin to activate Wnt target genes (Hoffmans et al., 2005). When Wnt signaling is absent, free $\beta$-catenin is bound by a destruction complex consisting of the tumor-suppressor gene products axis inhibitor (AXIN) and 
adenomatous polyposis coli (APC), and the serine/threonine kinases casein kinase 1 (CK1) and glycogen synthase kinase $3 \beta$ (GSK3 $\beta$ ) (Behrens et al., 1996). After binding AXIN and APC, $\beta$-catenin is phosphorylated by CK1 and GSK3 $\beta$ in a sequential manner on at least four conserved $\mathrm{N}$-terminal serine and threonine residues. $\mathrm{CK} 1$ phosphorylates $\beta$-catenin at Ser45, creating a priming site for GSK3 $\beta$ to subsequently phosphorylate the remaining residues, Thr41, Ser37, and Ser33. This creates a recognition motif for an E3-ubiqutin-ligase complex that contains $\beta$-transducin repeat containing protein ( $\beta$-TRCP), which tags $\beta$-catenin with ubiquitin molecules, targeting it for proteosomal degradation (Ikeda et al., 1998; Amit et al., 2002; Gao et al., 2002). In contrast, when Wnt proteins bind to their receptors, formation of the FrizzledLRP5/LRP6 complex through DVL (mammalian homologue of Drosphila Dishevelled) promotes the phosphorylation of LRP5 or LRP6 by CK1 and GSK3 $\beta$ (Zeng et al., 2008). Phosphorylation of LRP5 or LRP6 allows docking of AXIN1 thru the phosphorylated LRP residues, which removes AXIN1 from the destruction complex in the cytoplasm (Zeng et al., 2005). The recruitment of AXIN1 to the plasma membrane leads to inihibition of the phosphorylating ability of GSK3 $\beta$ and the destruction complex. This results in the escape of $\beta$-catenin and its movement to the nucleus. Relocation of $\beta$ catenin from the cytoplasm to the nucleus following its Wnt-induced stabilization is necessary for achieving efficient activation of Wnt target genes and ensuring appropriate physiological response. The way in which this is achieved has not been determined. These genes have not been well-defined in the hematopoietic system, with the exception of immature thymocytes, in which proliferation, cell adhesion, and antiapoptotic genes have been identified as Wnt targets (Staal et al., 2004). 
TECs are the main source of Wnt proteins in the thymus, while the Wnt receptor Fz is mostly found on thymocytes, which indicates a crosstalk between TECs

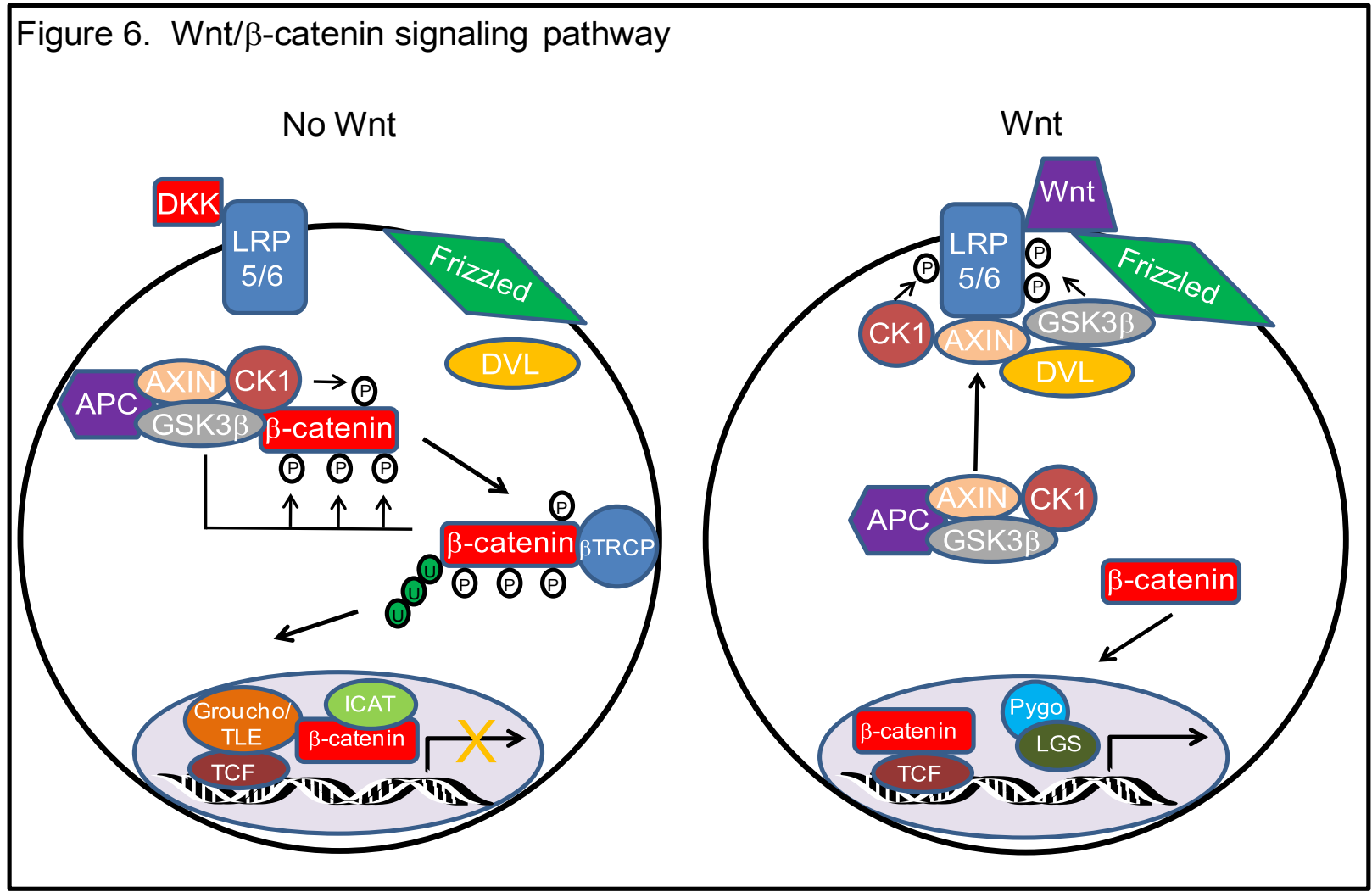

and thymocytes (Pongracz et al., 2003). Wnt signaling occurs in the thymus and is most active in the immature DN stages (Weerkamp et al., 2006) (Figure 4). The first report to identify a functional role for Wnt signaling in thymocyte differentiation used retroviruses encoding the extracellular Wnt-binding domains of $\mathrm{Fz}$ receptors as extracellular inhibitors of Wnt signaling. Fetal liver stem cells were transduced with these soluble Fz receptors and subsequently assessed for their ability to develop into $T$ cells using FTOC (Staal et al., 2001). These experiments showed a complete block of early thymocyte development, similar to that seen in $T c f 1^{\Delta 5 / \Delta 5} L e f 1^{-1-}$ double-knockout mice. This finding indicated that secreted Wnt factors are essential for intrathymic $T$ lineage development. In addition, the direct effects of Wnt factors on fetal thymocytes 
were observed in an in vitro culture system (Staal et al., 2001). Specifically, expression of Wnt1 and Wnt4 through retroviral transduction resulted in increased numbers of cultured thymocytes in the absence of thymic stroma, likely attributed to a combined effect on survival and proliferation (Staal et al., 2001). Therefore, Wnt proteins act as growth factors for early thymocytes. The aforementioned findings were supported by in vivo studies that demonstrated reduced cellularity in the thymus due to reduced proliferation of cells mainly at the DN and ISP stages of development in $W n t 1^{-1-W n t 4^{-/-}}$ mice (Mulroy et al., 2002). Studies have also shown that defects in T cell development occur in mice deficient for TCF1. Young TCF1-deficient mice have an incomplete block at the DN1, DN2, and ISP stages of thymocyte development, whereas older mice have a complete block most likely at the DN1 stage (Verbeek et al., 1995).

Several studies have shown that Wnt signaling is important at the DN to DP transition of thymocyte development. Expression of ICAT (Pongracz et al., 2006), which inhibits Wnt signaling by preventing binding of $\beta$-catenin to TCF and LEF factors, blocks this transition, but does not affect later stages of development. The secreted Wnt inhibitor Dikkopf-1 (DKK1), which blocks binding of Wnt to the required LRP coreceptor, inhibits thymocyte differentiation at the DN stage in a dose-dependent manner, such that high levels of DKK1 lead to complete inhibition of T-cell development at the DN1 stage (Weerkamp et al., 2006). Activation of the Wnt pathway by overexpressing activated forms of $\beta$-catenin resulted in the generation of more thymocytes (Mulroy et al., 2003), lack of requirement for pre-TCR signals in mice lacking pre-TCR (Gounari et al., 2001; Goux et al., 2005), and activated proliferationassociated genes in immature thymocytes (Staal et al., 2004). Conditional T-cell- 
specific deletion of $\beta$-catenin, using the proximal lymphocyte protein tyrosine kinase (LCK) promoter to control Cre expression, impaired T-cell development at the TCR $\beta$ selection checkpoint, contributing to a marked decrease in the number of peripheral $\mathrm{T}$ cells (Xu et al., 2003). In addition, conditional deletion of the APC tumor-suppressor gene, which is part of the $\beta$-catenin destruction complex, also disrupts $\mathrm{T}$ cell development in the thymus, partly due to its effect on $\beta$-catenin signaling (Gounari et al., 2001).

Some studies have demonstrated a role for Wnt signaling in DP to SP thymocyte transition, although $\mathrm{Wnt} / \beta$-catenin signaling is less active in signaling at this stage. Expression of CD4 by DP thymocytes is regulated partially by $\beta$-catenin-TCF signaling (Huang et al., 2006), and TCF1-deficient mice express lower levels of CD4 on DP and $\mathrm{CD}^{+} \mathrm{SP}$ cells. A series of studies showed that overexpressing stabilized $\beta$-catenin regulates the positive selection of thymocytes (Yu and Sen, 2007; Yu et al., 2007); the generation of fully selected $\mathrm{CD}^{+}$and $\mathrm{CD}^{+} \mathrm{SP}$ thymocytes occurred simultaneously when stabilized $\beta$-catenin was overexpressed, in contrast to the normal situation when generation of $\mathrm{CD}^{+}$cells occurs less frequently than generation of $\mathrm{CD}^{+}$cells. Collectively, previous studies have demonstrated a role for $\mathrm{Wnt} / \beta$-catenin signaling in DN proliferation and differentiation, DP survival, and $\mathrm{CD}^{+}$generation. 


\section{Cadmium}

\section{Human exposure}

Cadmium (Cd), a heavy metal, is an environmental pollutant due to its widespread and continual use. It currently ranks seventh on the Agency for Toxic Substances and Disease Registry/Environmental Protection Agency (ATSDR/EPA) list of Hazardous Substances (ATSDR, 2007). Cd levels in the environment vary widely due to its ability to be transported through air, water, and soil. Humans normally absorb $\mathrm{Cd}$ into the body either by ingestion or inhalation (Lauwerys et al., 1986). The daily intake of $\mathrm{Cd}$ is estimated to be approximately $10-50 \mu \mathrm{g}$, but can reach levels of $200-1000 \mu \mathrm{g}$ in highly contaminated areas (Nordberg, 2006). Cd concentrations in food normally range from $10-20 \mu \mathrm{g}$, while a cigarette contains $1-2 \mu \mathrm{g}$. Cd has a half-life of $15-20$ years in humans, which contributes to its toxicity (Jin et al., 1998). The heavy metal's toxicity is contributed mostly to its interaction with essential nutrients, such as zinc (Zn), iron (Fe), calcium (Ca), and copper (Cu) (Flora et al., 2008) (Figure 7). Cd has no physiological function in humans, thus, excessive accumulation in the body often results in diseases and occasionally death (Othumpangat et al., 2005).

Exposure to the heavy metal and its compounds primarily occurs in workplaces such as mining, smelting, processing, and battery manufacturing, whereas nonoccupational exposures come from various foods, contaminated water, and tobacco smoke. Natural sources of $\mathrm{Cd}$ that put $\mathrm{Cd}$ into the air include volcanic activity, forest fires, and windblown transport of soil particles. Food is usually the largest source of non-occupational exposure for non-smokers. Contamination of soil caused by mining, 
application of phosphate fertilizers, and atmospheric deposition of airborne Cd leads to increased uptake by crops and vegetables grown for human consumption. Foods that have high concentrations of $\mathrm{Cd}$ include mollusks and crustaceans, offal products such as kidney and liver, oil seeds, cocoa beans, and certain wild mushrooms. In addition, cereals such as rice and wheat, green leafy vegetables, potatoes, and root vegetables contain a higher concentration of $\mathrm{Cd}$ than other plant foods. Based on estimation of $\mathrm{Cd}$ intake, more than $80 \%$ of $\mathrm{Cd}$ from food comes from cereals, vegetables, and potatoes (Olsson et al., 2002). Cd in drinking water contributes only to less than a few percent of the total Cd intake (Olsson et al., 2002). In heavily contaminated areas, however, such as those in the vicinity of $\mathrm{Cd}$ emitting plants or in mining districts, both well water and rivers may be substantially contaminated by $\mathrm{Cd}$.

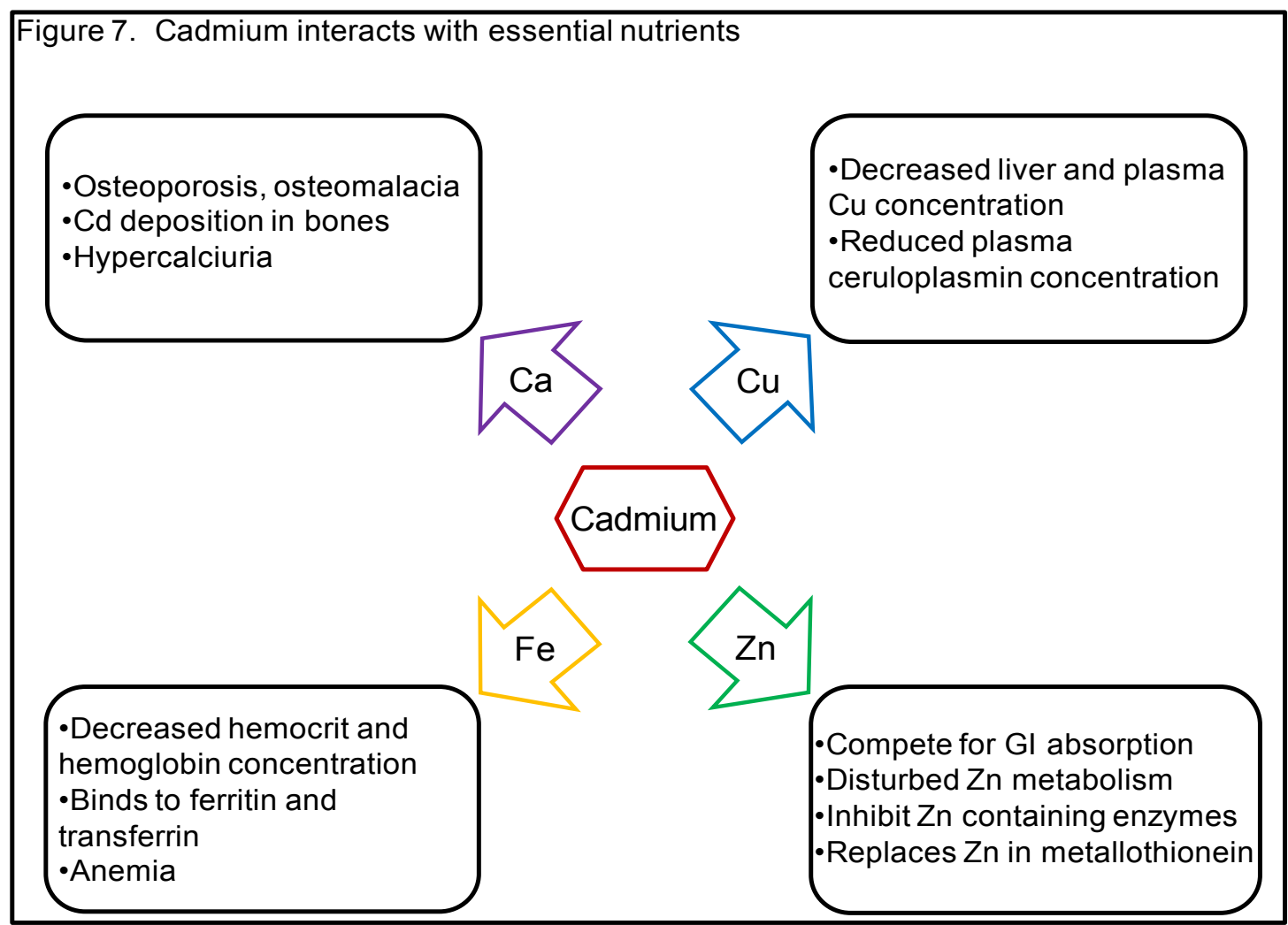




\section{Absorption and excretion}

Cd absorption from the gastrointestinal tract is the main route of $\mathrm{Cd}$ exposure in non-smoking humans. Approximately $3-10 \%$ of ingested $\mathrm{Cd}$ is absorbed from the gastrointestinal system, while $50 \%$ of $\mathrm{Cd}$ in inhaled smoke is absorbed through the bloodstream (Sahmoun et al., 2005). Smokers generally have Cd blood levels 4-5 times those of non-smokers (Elinder et al., 1976).

In animal studies, the fraction of $\mathrm{Cd}$ that is absorbed from the gastrointestinal tract is low, but increases with dose (Lehman and Klaassen, 1986). Once Cd is absorbed, it is transported into the liver, bound to albumin (Nordberg et al., 1992), where it induces the synthesis of metallothionein (MT). MT is a small molecular weight, cysteine-rich stress response protein that binds heavy metals with high affinity (Hamer, 1986). MT's high affinity for metals allows for protection against Cd toxicity as well as maintaining the homeostasis of certain essential metals in mammals (Klaassen et al., 1999b). The primary site for MT synthesis is the liver (Coyle et al., 1995; Quaife et al., 1999);however, other cells such as lymphocytes and monocytes as well as lymphoid tissues such as the thymus can produce MT in response to particular stimuli (Olafson, 1985; Coto et al., 1992; Leibbrandt and Koropatnick, 1994; Yurkow and Makhijani, 1998). Following release from the liver, MT-bound Cd enters the plasma. MT-bound Cd emerges in the glomerular filtrate, from where it is reabsorbed intracellularly by renal tubule cells. While in the renal tubule cells, Cd is cleaved from MT by lysosomal action, and $\mathrm{Cd}^{2+}$ ions are re-excreted into the tubular fluid. $\mathrm{Cd}$ is eliminated in the urine, however, the amount excreted only represents $0.005-0.01 \%$ of the total body burden (Friberg, 1986). 
Numerous studies have been conducted to determine the function of MT in Cd toxicology (Klaassen et al., 1999a). MT is easily induced by Cd and various metal ions, as well as by other stimuli (Kagi and Schaffer, 1988). Cd toxicity can be ameliorated by various MT inducers, particularly Zn (Klaassen et al., 1999a; Waalkes, 2003). Although MT plays a limited role in the initial distribution of Cd to various tissues (Liu et al., 1996), the retention of $\mathrm{Cd}$ in various tissues is MT-dependent. Cd mainly accumulates in kidney and liver, where high MT levels are found. Induction of hepatic MT abolishes biliary excretion of $\mathrm{Cd}$ (Klaassen, 1978), and renal Cd concentration is proportional to renal MT levels (Liu et al., 1996; Jarup et al., 1998). Molecules other than MT, such as albumin, cysteine, glutathione (GSH), and sulfydryl-rich proteins, can also form associations with $\mathrm{Cd}$.

Cd uptake is mediated by transport proteins such as divalent metal transport 1 (DMT1), metal transport protein1, calcium channel proteins, and the 8-transmembrane zinc-related iron-related protein (ZIP8) to reach the target tissues. Alteration of transport protein expression can affect cellular $\mathrm{Cd}$ uptake and accumulation, and as a result, impact Cd toxicity (Zalups and Ahmad, 2003; Dalton et al., 2005; Leslie et al., 2006). For example, a diet low in iron increases the expression of the DMT1, which transports iron. DMT1 also transports $\mathrm{Cd}$, thus low iron stores can increase $\mathrm{Cd}$ absorption, possibly contributing to toxicity.

The finding that pretreatment of animals with a low dose of $\mathrm{Cd}$ makes animals highly tolerant to Cd-induced lethality first demonstrated the role of MT in Cd toxicity (Goering and Klaassen, 1983). In wild-type and MT-null mice administered increasing doses of Cd, wild-type mice acquired tolerance to $\mathrm{Cd}$ lethality, with a 7-fold difference in 
$\mathrm{LD}_{50}$ values, while MT-null mice did not display such tolerance (Park et al., 2001), indicating a critical role for MT as a major protein in protecting acute Cd poisoning. The liver is the major target organ of toxicity following acute $\mathrm{Cd}$ poisoning, and $\mathrm{Cd}$ hepatotoxicity is the major cause of acute Cd lethality (Goering and Klaassen, 1983). Acquired tolerance to acute $\mathrm{Cd}$ hepatotoxicity depends on the presynthesized MT in the liver, which functions to sequester $\mathrm{Cd}$ in the cytosol, which in turn, reduces the amount of Cd available for other critical organelles (Goering and Klaassen, 1983). The liver, spleen, and bone are important hematopoietic organs, that are all targets of $\mathrm{Cd}$ exposure (Klaassen et al., 1999a). Therefore, mice deficient in MT are likely more sensitive than wild-type mice to Cd-induced anemia and immunotoxicity (Liu et al., 1999). Blood MT is non-protective, however, low to moderate levels of blood MT has effects on the severity of autoimmune disease and on the development of adaptive immune functions (Lynes and Yin, 2006). Mice deficient in MT exhibited a significantly higher humoral response to challenge with ovalbumin compared to wild-type controls. Overall circulatory immunoglobulin levels are also significantly higher in MT-null mice than in wild-type mice (Crowthers et al., 2000).

\section{Toxicology and Carcinogenicity}

Itai-Itai disease

Public awareness of the toxic effects of Cd began with the post World-War-II (1950) outbreak in Toyama Prefecture, Japan, of "itai-itai" disease, which was the first Cd poisoning in the world. Itai-itai, or "ouch ouch" disease, so named due to the severe pain in the joints and spine, was caused by ingestion of runoff water containing Cd 
released from mining companies in surrounding mountains (Kagawa, 1994). Farmers used the contaminated water to irrigate crops, such as rice paddies. Cd concentrated in those crops, and when people ingested them, particularly women, they experienced excruciating pain. Cd interfered with calcium (Ca) metabolism leading to reduction in Ca levels, which reduced density and strength of bones, often leading to bone breakage.

\section{Reproductive effects}

Oocyte development and associated events have been disrupted by $\mathrm{Cd}$ administration in numerous different species, including Xenopus laevis (Lienesch et al., 2000; Fort et al., 2001; Fort et al., 2002), rats (Paksy et al., 1989; Paksy et al., 1992; Piasek and Laskey, 1994; Paksy et al., 1997b), mice (Rehm and Waalkes, 1988), hamsters (Saksena and Salmonsen, 1983; Rehm and Waalkes, 1988), pigs (Vrsanska et al., 2003; Mlynarcikova et al., 2005), and sheep (Leoni et al., 2002). Exposure to Cd of cultured human ovarian granulosa cells was found to cause reduction in progesterone production when compared with controls, and also caused morphological alterations in a time-and dose-dependent manner, with rounding up of cells after 4-8 $\mathrm{h}$, retraction of cellular extensions, and detachment from neighboring cells (Paksy et al., 1997a). Testicular changes due to Cd toxicity have been seen in a variety of animal models at different stages of growth and maturity. Gonadal development in mouse embryos exposed to Cd in early organogenesis was studied by Tam and Liu (1985). Genital ridge size was reduced in exposed animals, with retarded germ cell migration into the ridges, resulting in depleted populations of germ cells, defective maturation of 
gametes and subfertility in male offspring (Tam and Liu, 1985). Also, adult male rats have been shown to develop gonadal damage following administration of $\mathrm{Cd}$, either orally or subcutaneously (SC). Focal testicular necrosis and reduced spermatogenesis were seen in rats that received a single dose of $100-150 \mathrm{mg} \mathrm{Cd} / \mathrm{kg}$ orally within 2 weeks of administration (Kotsonis and Klaassen, 1977). Rats injected with a large dose of $\mathrm{CdCl}_{2}$ (7 mg/kg SC) showed pronounced testicular hemorrhage and edema $24 \mathrm{~h}$ after treatment (El-Ashmawy and Youssef, 1999). In addition, heavy smoking has been associated with low sperm count and motility. A strong positive relationship has been identified between smoking, serum and seminal fluid Cd levels in infertile Nigerian males (Akinloye et al., 2006). Other studies, however, have shown no differences in semen quality or fertility between smokers and non-smokers, even though significantly increased amounts of $\mathrm{Cd}$ were found in seminal fluid in those smoking 20 or more cigarettes a day (Saaranen et al., 1989). In the rat model, increased rates of abnormal sperm morphology have been noted with increased seminal Cd levels, with positive correlation with TNF- $\alpha$ and IFN- $\gamma$, and a negative relationship with IL-4 (AI-Bader et al., 1999). All seminal parameters and cytokine differences in this model were reversible by administration of $\mathrm{Zn}$ with $\mathrm{Cd}$. It has been suggested that absence of certain micronutrients in the diet contribute to male infertility associated with increased $\mathrm{Cd}$ levels (Akinloye et al., 2006).

Cd may also reduce the possibility of a successful pregnancy by interfering with the development of the pre-implantation embryo. Gamete fusion in the ovine model was found to be significantly reduced following exposure to $2-20 \mu \mathrm{M} \mathrm{Cd}$ (Leoni et al., 2002). Fertilization of mouse oocytes was unaffected when cultured at $1.6 \mu \mathrm{M} \mathrm{Cd}$, and 
treated ova cleaved into two-cell stage embryos at a comparable rate to controls, although a reduced number of these embryos reached blastocyst stage (Schmid et al., 1983). In vitro studies in which murine embryos were cultured at higher Cd concentrations $(10-50 \mu \mathrm{M})$ at the two-cell stage, demonstrated a dose-dependent inhibition of developmental progression (Storeng and Jonsen, 1980). In vivo exposure of the murine embryo to $\mathrm{Cd}$ at the two-cell stage by SC injection of the dam with $25-38$ $\mu \mathrm{M} \mathrm{Cd} / \mathrm{kg}$ body weight on the morning of day 2 (D2) failed to prevent initiation and maintenance of pregnancy when examined on D8, but did delay implantation (De et al., 1993). Embryos that implanted went on to become normal fetuses, with resorption rates and body weights comparable to controls (De et al., 1993). Studies have shown that $\mathrm{Cd}$ inhibits gap junction, intercellular communication, and connexin phosphorylation (Jeong et al., 2000; Fang et al., 2001), all of which are necessary for progression from the eight-cell stage through to compaction (Hardy et al., 1996; Kidder and Winterhager, 2001). Protection of the early embryo from Cd toxicity has been achieved by preventing Cd uptake by cells by pre- or co-incubation with $\mathrm{Zn}$ at 100x molar dose of $\mathrm{Cd}(\mathrm{Yu}$ and Chan, 1988; De et al., 1993) and by co-culture with nifedipine $\left(\mathrm{Ca}^{2+}\right.$ channel blocker $)$ at 0.01x molar dose of Cd (De et al., 1993). Antioxidants are also known to be protective against Cd toxicity (Peters et al., 1995).

The presence of MT in the placenta is generally accepted to be a protective mechanism against $\mathrm{Cd}$ toxicity within the cells in which it is produced, and is also thought to restrict $\mathrm{Cd}$ movement across the placenta, as the level of $\mathrm{Cd}$ is lower in fetal than in maternal blood (Goyer and Cherian, 1992). In contrast, some (Goyer and Cherian, 1992; Torreblanca et al., 1992) think MT has detrimental effects, by binding Zn 
or by interfering with the ability of trophoblast cells to handle $\mathrm{Ca}$ and $\mathrm{Zn}$ at the cytosolic level. Using the perfused human placenta, Wier et al. (1990) demonstrated a reduction in transplacental $\mathrm{Zn}$ transfer to the fetus, and also a drop in human chorionic gonadotrophin ( $\mathrm{hCG}$ ) production by the placenta, beginning $4 \mathrm{~h}$ after exposure. Placentas of smoking mothers contained twice the $\mathrm{Cd}$ and approximately half the progesterone of those of non-smokers. Piasek et al found a reduction in placental iron in smokers with elevated levels of placenta Cd (Piasek et al., 2001). Cd interference with progesterone biosynthesis in cultured human trophoblast cells has been linked with reduced activity of P450 cholesterol side-chain cleavage enzyme and decreased $3 \beta-$ hydroxysteroid dehydrogenase enzyme mRNA (Kawai et al., 2002).

\section{Teratogenicity}

Cd is known to exert teratogenic and embryotoxic effects in many species as confirmed by animal studies (Webster and Messerle, 1980; Messerle and Webster, 1982; Menoud and Schowing, 1987; De et al., 1990; Sunderman et al., 1992). The changes induced are dependent on the strain and species studied, the dose of $\mathrm{Cd}$ administered, the route of administration, and the stage of embryogenesis (Layton and Layton, 1979; Feuston and Scott, 1985; Holt and Webb, 1987; De et al., 1990). Toxic renal effects in 2- to 60-day-old postnatal offspring were observed when pregnant rats were administered $\mathrm{CdCl}_{2}\left(0.5 \mathrm{mg} / \mathrm{kg}^{-1} / \mathrm{day}\right)$ orally throughout gestation (Jacquillet et al.,

2007). When pregnant rats were treated with 0.3 or $0.6 \mathrm{mg} / \mathrm{kg}^{-1} \mathrm{Cd}$ subcutaneously from E7 to E15, sensorimotor development delays were observed in the offspring (Minetti and Reale, 2006). In the hamster, Gale and Layton (1980) injected a single 
dose of $2 \mathrm{mg} / \mathrm{kg} \mathrm{CdSO}{ }_{4}$ intravenously on E8, and found numerous craniofacial, skeletal, and soft tissue abnormalities upon examination of fetuses on E15. When a wholeembryo culture assay was used for hamster embryos, a $70 \%$ abnormality rate in embryos cultured at $0.25 \mathrm{mM} \mathrm{Cd}$ on E8 was observed, with animals exhibiting growth retardation, reduction in somite gain, axial anomaly and neural tube defect (Wlodarczyk et al., 2001). Cd has also been shown to have teratogenic effects on limb development. Following administration of $\mathrm{CdSO}_{4}$ to $\mathrm{C} 57 \mathrm{BI} / 6$ mice at day 9.5 of gestation, a high incidence of postaxial forelimb ectrodactyly in offspring resulted due to inhibition of the anterior/posterior formation process (Scott et al., 2005). This process is controlled by Shh signaling.

Cd has not been shown to be teratogenic in humans; however, an inverse relationship has been found between birth weight and cord blood Cd levels (GaliciaGarcia et al., 1997), birth weight and placental Cd concentration (Ronco et al., 2005), and between birth length and maternal blood Cd (Nishijo et al., 2004). There is an association between maternal $\mathrm{Cd}$ exposure and early delivery, which may serve as an explanation for smaller babies born to women who smoke during pregnancy (Nishijo et al., 2002). An inverse relationship has also been demonstrated between birth weight and Cd content in hair of newborns (Huel et al., 1981; Frery et al., 1993). Cd blood levels in newborn infants have been found to be $70 \%$ of maternal levels (Lagerkvist et al., 1992). The difference in Cd level can most likely be attributed to placental function, as perfusion of human placentas with $\mathrm{Cd}$ showed that transfer rate from maternal to fetus was very slow (Boadi et al., 1991). Cd did not appear on the fetal side of the placenta until 40 minutes $(\mathrm{min})$ after perfusion started, and reached a steady state 
approximately 1 hour $(\mathrm{h})$ later, at which time the concentration in the fetal perfusate was $1 / 20$ that of the maternal.

Postnatal effects due to abnormally high levels of $\mathrm{Cd}$ during gestation include significantly increased DNA synthesis in the bowel and bone marrow in 6-week old rats following administration of $\mathrm{Cd}$ orally to pregnant dams at a dose of 50 parts per million (ppm) in drinking water (Konecki et al., 2000), and depressed immune function and sensorimotor abilities in children (Schoeters et al., 2006). Human studies are not conclusive, so additional work must be done to determine the extent and type of damage to children following prenatal exposure.

\section{Immunotoxicity}

There have been numerous studies on the immunomodulatory effect of $\mathrm{Cd}$ in humans and experimental animals; however, the findings remain controversial (Descotes, 1992). Dan et al. (2000) showed that Cd causes significant suppression of humoral and cell-mediated immune response in mice, and suggested that this effect may be due to its cytotoxic action on liver, kidney, and immune cells. There have also been reports that $\mathrm{Cd}$ induces immunostimulation in experimental animals (Koller and Roan, 1977). This conflict amongst findings may be attributed to varying doses, route of administration, length of $\mathrm{Cd}$ treatment, and sensitivity of immune systems between different animal species. Strain specific immune responses to $\mathrm{Cd}$ may be due to variation of $\mathrm{Cd}$ binding to MT and tissue storage or possibly because strains differ in their proliferative response level to polyclonal T cell mitogens (Dan et al., 2000). The thymus is a target organ of Cd-induced toxicity. Following Cd-treatment, damage to the 
thymus as well as changes in the proliferation rate of thymocytes in rats results (Morselt et al., 1988). In addition, several in vivo experiments have demonstrated that Cd causes decreased thymus weight as well as thymic atrophy (Borgman et al., 1986; Mackova et al., 1996; Liu et al., 1999). In adult mice, Dong et al. (2001) observed a decrease in DP cells. Pathak and Khandelwal supported these findings and demonstrated that Cd exposure increased the number of DN cells (2007).

Cd exposure results in modulation of antibody production, inhibition of B-cell activation, enhancement of mortality in mice challenged with streptococci, and decreased mortality of influenza-infected mice (Koller et al., 1976; Gardner et al., 1977; Fujimaki et al., 1982; Chaumard et al., 1983; Ohsawa et al., 1986; Daum et al., 1993). In vitro exposure to $10 \mu \mathrm{M} \mathrm{Cd}$ induced apoptotic features in mouse thymocytes (Fujimaki et al., 2000). A study demonstrated that Cd (0-100 ppm), when given to rats in drinking water, showed a differential effect on the blood lymphocyte phenotyping (Lafuente et al., 2004). Evidence suggests the mechanism of Cd toxicity is attributed to oxidative stress, i.e. increased lipid peroxidation, reactive oxygen species (ROS) generation, and alterations in GSH and related enzymes, under both in vitro and in vivo conditions (Stohs and Bagchi, 1995; Hart et al., 1999; Thevenod et al., 2000; de la Fuente et al., 2002). The role of ROS in Cd induced apoptosis (Pulido and Parrish, 2003; Lemarie et al., 2004) is further supported by activation of redox sensitive AP-1 transcription factor and alteration in GSH metabolism prior to apoptosis (Hart et al., 1999). Immune cells are highly sensitive to oxidative stress due to major production of ROS (Meydani et al., 1995). ROS plays a major role in immune function by acting as intracellular signals. Also, oxidant-antioxidant balance is important for maintenance of 
the immune response (Kim et al., 2001). The apoptogenic potential of $\mathrm{Cd}$ was demonstrated in murine thymocytes involving mitochondrial membrane depolarization, and caspase activation, and ROS and GSH acting as critical mediators (Pathak and Khandelwal, 2006). Differential effects of $\mathrm{Cd}$ on the spleen and thymus have been demonstrated (Pathak and Khandelwal, 2007b). Suppression of cell proliferative response, thymic atrophy, and splenomegaly following $\mathrm{Cd}$ exposure may be due to oxidative stress followed by activation of the mitochondrial-caspase dependent apoptotic pathway (Pathak and Khandelwal, 2007b). Differential susceptibility of various $\mathrm{T}$ subsets to the apoptogenic effects of $\mathrm{Cd}$ in the order of $\mathrm{CD} 8^{+}>\mathrm{DN}>\mathrm{CD} 4^{+}>\mathrm{DP}$ was reported (Dong et al., 2001). In addition, Cd treatment affected cell surface marker expression and led to phenotypic changes, characterized by a decline in DP cells and a marked lowering in $\mathrm{CD}^{+} / \mathrm{CD}^{+}$ratio mainly due to a significant increase in $\mathrm{CD}^{+}$ subsets (Dong et al., 2001). The authors concluded that Cd was capable of inducing apoptosis in cultured mouse thymocytes in a dose and time-dependent manner (Dong et al., 2001). Another study examining the effect of in vitro exposure to $\mathrm{Cd}$ on thymocyte development showed that $\mathrm{Cd}$ significantly suppressed the proportion of $\mathrm{CD} 4^{+}$ cells followed by DP (Pathak and Khandelwal, 2007a). The DN and CD8 ${ }^{+}$cells, on the other hand, were markedly enhanced (Pathak and Khandelwal, 2007a). In addition, cytokine analysis demonstrated an inhibition of IL-2 and IFN- $\gamma$ release by Th1 cells, and IL-4 release by Th2 cells (Pathak and Khandelwal, 2007a). The authors attributed this to a lowered $\mathrm{CD} 4^{+}$population resulting in a decreased proportion of Th1 and Th2 cells, or to an indirect influence of the metal mediated by the endocrine system (Lafuente et al., 2004). Th1 and Th2 cells mediate cytotoxic and local inflammatory reactions, and 
therefore play important roles in combating intracellular pathogens including viruses, bacteria, and parasites.

When adult male rats were exposed for one month to $\mathrm{CdCl}_{2}$, Cd accumulated in the spleen (at $\geq 50 \mathrm{ppm}$ ), and in the thymus (at $\geq 10 \mathrm{ppm}$ on (Lafuente et al., 2003). In both spleen and thymus, the B lymphocytes increased with doses of 5 and $10 \mathrm{ppm}$, and decreased with the doses of 25-100 ppm (Lafuente et al., 2003). In the spleen, doses of 25 and $50 \mathrm{ppm}$ decreased $\mathrm{CD} 4^{+}$cells and the doses of 5 and $10 \mathrm{ppm}$ increased $\mathrm{CD}^{+}$cells (Lafuente et al., 2003). In addition, results suggest that the spleen is more sensitive to Cd exposure than the thymus, although the accumulation of the metal was higher in the thymus than the spleen (Lafuente et al., 2003). Another study by Lafuente et al. (2004) demonstrated that Cd effects on the distribution of blood lymphocyte subsets suggest that $\mathrm{Cd}$ inhibits the humoral and cellular immune responses with lower doses (5-10 ppm), but opposite effects are demonstrated with higher doses (25-100 ppm). In a study that investigated the role of estradiol $\left(E_{2}\right)$ on the immunotoxic effects of $\mathrm{Cd}$ in the rat, results indicated that $\mathrm{Cd}$ and $\mathrm{E}_{2}$ not only share certain similar cellular pathways but also can interact to alter immune functions (Pillet et al., 2006). In addition, Cd can also modulate the hormonal balance and may exert estrogenic effects via interaction with estrogen receptors (ERs). This suggests that females may be at a greater risk than males for Cd-induced immunomodulation.

In immune and inflammatory responses, macrophages are activated (Auger, 1992) and secrete cytokines, ROS, reactive nitrogen species such as nitric oxide (NO) (Ding et al., 1988) and eicosanoids such as prostaglandin $E_{2}\left(\mathrm{PGE}_{2}\right)$. These substances all contribute to tissue damage mediated by activated macrophages (Laskin 
and Pendino, 1995). Both $\mathrm{NO}$ and $\mathrm{PGE}_{2}$ are inflammatory and immunomodulatory mediators in mammalian physiology (Moncada et al., 1991; Reilly et al., 1998). Several oxidative stressors can induce the co-expression of inducible nitric oxide synthase (iNOS) and cyclooxygenase type-2 (COX-2), which synthesizes $\mathrm{NO}$ and $\mathrm{PGE}_{2}$, respectively (Feng et al., 1995; Swierkosz et al., 1995; O'Banion, 1999). A study reported that in vitro $\mathrm{Cd}$ exposure in non-cytotoxic conditions induces iNOS expression (Ramirez et al., 1999) and enhances lipid peroxidation, arachidonic release, and GSH release from mouse peritoneal macrophages (Ramirez et al., 2001). Ramirez and Gimenez (2003) demonstrated that chronic exposure through drinking water (15 ppm for 2 months) induces redox changes in favor of pro-oxidant conditions, and increases synthesis of $\mathrm{NO}$ and $\mathrm{PGE}_{2}$ in mouse peritoneal macrophages (Ramirez and Gimenez, 2003).

Neonatal exposure to environmentally relevant levels of $\mathrm{Cd}(10 \mathrm{ppb}$ or $5 \mathrm{ppm})$ via maternal milk resulted in gender-specific delays in the development of females (Pillet et al., 2005). Also, exposure to Cd through maternal milk also produced transitory and persistent alterations of immune functions (Pillet et al., 2005). The immunotoxic effects were dependent on the type of immune cell, the developmental stage, and the level of exposure. Transitory and persistent alterations of the cytotoxic activity of NK-cells were only observed in males (Pillet et al., 2005). This was the first report of a gender-specific difference in the immunotoxic effects of $\mathrm{Cd}$.

Exposure to $\mathrm{Cd}$ at sub-toxic levels has been documented to cause impairment of immunosurveillance, which controls expression and inactivation of viruses and bacteria. Significant depression in the phagocytic activity (Loose et al., 1978) as well as 
suppression of humoral and cell-mediated immune responses (Dan et al., 2000) were also reported. It was found that susceptibility to bacteria in Cd-exposed mice was due to a defect of macrophage recruitment to sites of infection (Simonet et al., 1984). Two studies demonstrated that Cd increases susceptibility of affected individuals to bacterial and viral infections (Shen et al., 2001; Simonyte et al., 2003).

The effects of $\mathrm{Cd}$ on human cytokine responses, in particular $\mathrm{T}$ cell-derived cytokines, are fragmentary and contradictory. One study reported a significant depression of NK cell activity, but no changes in IFN- $\gamma$ production by $\mathrm{Cd}$ treatment (Daniels et al., 1987). In contrast, another study demonstrated a significant enhancement in the IFN- $\gamma$ production following occupational $\mathrm{Cd}$ exposure in men (Yucesoy et al., 1997). Hemdan et al. (2006) showed that human peripheral blood mononuclear cells exposure to low and moderate Cd doses $(0.013-13.3 \mu \mathrm{M})$ resulted in a clear bias of the immune response toward Th1 or Th2 depending on the activation method applied (Hemdan et al., 2006). When the cells were activated with mononuclear antibodies (anti-CD3/anti-CD28/anti-CD40) and exposed to Cd acetate for $24 \mathrm{~h}$, secretion of IL-1 $\beta$, TNF- $\alpha$, and IFN- $\gamma$ was greatly inhibited compared to the production of IL-4 and IL-10, which indicates a Th2 biased immune response. When the cells were stimulated with bacterial antigen (heat-killed Salmonella Enteritidis) and exposed to $\mathrm{Cd}$ acetate for $24 \mathrm{~h}$, secretion of IL-10 was highly suppressed compared to that of IFN- $\gamma$ and TNF- $\alpha$, while IL-4 was undetectable. These results imply that low Cd polarizes the immune response toward Th2 in cells stimulated via T cell receptor, while a polarized Th1 response is induced by bacterial antigens (Hemdan et al., 2006). In a study by Krocova et al. (2000), in vitro treatment of splenocytes from Balb/c mice with 
Cd $(20 \mu \mathrm{g} / \mathrm{ml})$ demonstrated that Cd seemed to trigger the Th2 cytokine pathway (IL-4, IL-10). This effect of Cd may imply the possible autoimmune or allergic complications in individuals exposed to this heavy metal (Krocova et al., 2000).

\section{Carcinogenic effects}

The toxicology and carcinogenicity of $\mathrm{Cd}$, and its environmental impacts have been well studied (Waalkes, 2000; Waalkes, 2003). There is sufficient evidence in humans to classify $\mathrm{Cd}$ and $\mathrm{Cd}$ compounds as carcinogens based on epidemiological studies demonstrating a link between $\mathrm{Cd}$ and lung, and possibly prostate, cancer (IARC, 2004). In addition, experimental animal studies demonstrate that $\mathrm{Cd}$ and $\mathrm{Cd}$ compounds by multiple routes of exposure induce benign and malignant tumor formation at various sites in many species of experimental animals (Waalkes et al., 1992a; Waalkes et al., 1992b; Waalkes and Rehm, 1994; Waalkes et al., 1999a; Waalkes et al., 1999b; Waalkes, 2000; Achanzar et al., 2001; Waalkes, 2003; Goyer et al., 2004). In rodents, Cd has induced tumors in several organs. Various Cd compounds produced adenocarcinomas of the lung in rats after inhalation (Takenaka et al., 1983). Tumors of the prostate and the pancreas were induced by subcutaneous injection of $\mathrm{CdCl}_{2}$ in rats, tumors of the testis were observed following oral exposure of rats, and Cd produced local tumors at various sites of injection, typically sarcomas, in rats and mice (Waalkes, 2000). Cd administration that was linked with tumors of the prostate and testis in experimental animals was prevented by $\mathrm{Zn}$ administration (Nordberg et al., 1992). Although a positive relationship has been demonstrated 
between proliferative testicular lesions and Cd in rats (Waalkes et al., 1999a; Waalkes et al., 1999b), no definitive link exists in humans.

The first studies to suggest a link between $\mathrm{Cd}$ and prostate cancer showed an increased risk of disease in occupationally exposed workers in a nickel-Cd battery factory (Potts, 1965; Kipling, 1967). Additional occupational studies demonstrated an association between $\mathrm{Cd}$ exposure and an increase in prostate cancer risk and mortality (Blair and Fraumeni, 1978; Dubrow and Wegman, 1984). More recent studies failed to show a link between occupational exposure to $\mathrm{Cd}$ and prostate cancer; however, studies have found that prostate cancer was associated with dietary exposure to $\mathrm{Cd}$ through drinking water and food (Bako et al., 1982; Elghany et al., 1990; West et al., 1991).

\section{Mechanisms of toxicity}

Oxidative stress

Cd, unlike other heavy metals, is unable to generate free radicals by itself; however, reports have indicated that superoxide radical, hydroxyl radical, and NO radicals could be generated indirectly (Galan et al., 2001). Cd can generate non-radical hydrogen peroxide, which by itself becomes a significant source of free radicals via Fenton chemistry (Watanabe et al., 2003). Cd could replace Fe and $\mathrm{Cu}$ from many cytoplasmic and membrane proteins like ferritin, which would then release and increase the concentration of unbound $\mathrm{Fe}^{2+}$ or $\mathrm{Cu}^{2+}$ ions. These free ions participate in causing oxidative stress via Fenton reactions (Casalino et al., 1997; Waisberg et al., 2003). 
Numerous studies in animal models have shown that $\mathrm{Cd}$ intoxication significantly increased malondialdehyde and GSH peroxidase (Yang et al., 2003). Acute intoxication of animals with Cd has shown increased activity of antioxidant defense enzymes like Cu-Zn containing superoxide dismutase, catalase, GSH peroxidase, GSH reductase, and glutathione-S-transferase (Ognjanovic et al., 2003). Studies have shown that the number of cells with DNA single strand breaks and the levels of cellular DNA damage were significantly higher in Cd exposed animals. Reports have shown that antioxidants like vitamin $\mathrm{C}$ and vitamin $\mathrm{E}$ have demonstrated protection against $\mathrm{Cd}$ induced toxicity in different animal models (Ognjanovic et al., 2003). Supplementation of these natural antioxidants reduced ROS levels, lipid peroxidation, hematological values, and enzymatic and non-enzymatic components of antioxidant defense system.

\section{Genotoxicity}

The $\mathrm{Cd}^{2+}$ ion easily substitutes for the $\mathrm{Ca}^{2+}$ ion in biological systems, because it carries the same charge and has a similar radius. Compared to the $\mathrm{Zn}^{2+}$ ion, the radius of the $\mathrm{Cd}^{2+}$ ion is larger, but $\mathrm{Cd}^{2+}$ ions can substitute for $\mathrm{Zn}^{2+}$ ions in many enzymes and transcription factors. The genotoxicity of $\mathrm{Cd}$ is attributed to indirect mechanisms such as the generation of ROS, inhibition of DNA repair enzymes, and deregulation of cell proliferation. Cd has been shown to induce the formation of ROS, both in vitro and in vivo. CdS induced $\mathrm{H}_{2} \mathrm{O}_{2}$ formation in human polymononuclear leukocytes, and $\mathrm{CdCl}_{2}$ increased production of superoxide in rat and human phagocytes (Sugiyama, 1994). In support of this, induction of DNA strand breaks and chromosomal aberrations by $\mathrm{Cd}$ in mammalian cells was suppressed by antioxidants and antioxidative enzymes (Ochi et 
al., 1987; Stohs et al., 2001; Valko et al., 2006). The induction of oxidative stress by Cd is interpreted by its inhibitory effects on antioxidant enzymes such as catalase, superoxide dismutase, GSH reductase, and GSH peroxidase (Valko et al., 2006). Cd is considered co-mutagenic and exacerbates the mutagenicity of UV raditation, alkylation, and oxidation in mammalian cells (Hartwig and Schwerdtle, 2002). Cd inhibits several types of DNA repair such as base excision, nucleotide excision, mismatch repair, and the elimination of the premutagenic DNA precursor 8-oxo-dGTP (Hartwig and Schwerdtle, 2002). Low concentrations of Cd inhibited the repair of oxidative DNA damage in mammalian cells (Dally and Hartwig, 1997; Fatur et al., 2003). In regards to nucleotide excision repair, Cd interfered with the removal of thymine dimers after UV irradiation by inhibiting the first step of this repair pathway, which is the incision at the DNA lesion (Hartwig and Schwerdtle, 2002; Fatur et al., 2003). Cd disrupted the removal of 8-oxo-dGTP from the nucleotide pool by inhibiting the 8-oxo-dGTPases of bacterial and human origin (Bialkowski and Kasprzak, 1998). A molecular mechanism related to the inactivation of DNA repair proteins involves the displacement of $\mathrm{Zn}$ from $\mathrm{Zn}$-finger proteins structures in the DNA repair proteins such as from the xeroderma pigmentosum group A (XPA) protein, which is required for nucleotide excision repair, and from the formamidopyrimidine [fapy]-DNA glycosylase (Fpg) protein, which is involved in base excision repair in E.coli (Asmuss et al., 2000). Cd induces a conformation shift in the $\mathrm{Zn}$ binding domain of the tumor suppressor protein p53 (Meplan et al., 1999). In addition to inhibiting repair proteins directly, Cd downregulates genes involved in DNA repair in vivo (Zhou et al., 2004). In Cd-adapted cells, the impairment of DNA repair by Cd may be especially harmful. Cd induces several genes 
for $\mathrm{Cd}$ and ROS tolerance such as those coding for MT, GSH synthesis and function, catalase and superoxide dismutase (Stohs et al., 2001), which establishes an environment where prolonged cell survival in the presence of Cd occurs (Chubatsu et al., 1992).

Tolerance to Cd toxicity may constitute an extended opportunity for induction of further critical mutations (Achanzar et al., 2002). Cd interacts with a number of cellular signaling pathways, many of which are associated with mitogenic signaling. DNA synthesis and proliferation of rat myoblast cells (von Zglinicki et al., 1992) and rat macrophages (Misra et al., 2002) were stimulated by submicromolar concentrations of Cd. In various cell types in vitro, Cd induces receptor-mediated release of second messengers inositol-1,4,5-trisphosphate and $\mathrm{Ca}$, it activates various mitogenic protein kinases, transcription, and translation factors, and it induces the expression of cellular proto-oncogenes c-fos, c-myc, and c-jun (Waisberg et al., 2003).

In addition to directly stimulating mitogenic signals, Cd also inhibits negative controls of cell proliferation, such as inactivating the tumor suppressor protein p53 and inhibiting the p53 response to damaged DNA (Meplan et al., 1999). Another mechanism by which $\mathrm{Cd}$ affects cell proliferation is through disruption of the WNT/ $\beta$ catenin pathway resulting in dysregulation of cadherin-mediated cell-cell adhesion system and of cell-cell communication. Studies have shown that Cd perturbs the Wnt pathway in chick embryonic periderm (Thompson et al., 2008) and proximal tubule cells (Prozialeck et al., 2003; Thevenod et al., 2007). 


\section{Estrogenic effects}

At a dose similar to the World Health Provisional Tolerable Weekly Intake, Cd mimics the in vivo effects of estrogen in target organs in animal studies (Johnson et al., 2003). Johnson et al. (2003) determined that, similar to estrogens, exposure of ovariectomized animals to a low dose of $\mathrm{Cd}(5 \mu \mathrm{g} / \mathrm{kg}$ body weight) results in the induction of estrogen target genes and an increase in uterine wet weight that are blocked by an antiestrogen. In the mammary gland, Cd also induces estrogen target genes and promotes the growth and differentiation that are blocked by an antiestrogen. In utero exposure to Cd mimics in utero exposure to estradiol (Johnson et al., 2003). When female offspring are exposed to $\mathrm{Cd}$ in utero, there is an accelerated onset of puberty and altered mammary gland development (Johnson et al., 2003). In support of a role for $\mathrm{Cd}$ in breast cancer, exposure to the metal has been linked to an increased risk of the disease in a hypothesis-generating case-control study that examined over 33,000 death certificates attributed to breast cancer and over 117,000 non-cancer deaths between 1984-1989 that were coded for occupation and industry (Cantor et al., 1995). The study found that Cd was associated with an approximate 8 to $20 \%$ increase in breast cancer risk among white women and $50-130 \%$ increase in risk among AfricanAmerican women. Similar to estradiol, $\mathrm{Cd}$ activates $\mathrm{ER} \alpha$ through the ligand binding domain. When COS-1 cells are transiently cotransfected with GAL-ER, a chimeric receptor containing the DNA binding domain of the transcription domain of ER $\alpha$, a GAL4-responsive reporter gene, and treated with $\mathrm{Cd}$, there is an increase in reporter gene activity that is blocked by an antiestrogen suggesting that Cd activates ER $\alpha$ through the ligand binding domain of the receptor (Stoica et al., 2000). It has been 
reported that $\mathrm{Cd}$ modulates steroid hormone-dependent signaling in ovaries in rats, in a breast cancer cell line, and in Cd-transformed prostate epithelial cells (BenbrahimTallaa et al., 2007; Brama et al., 2007). However, in in vitro estrogenicity assays based on ER activity, no effect of Cd was detected (Silva et al., 2006).

\section{Androgenic effects}

The exact mechanism by which androgens affect prostate carcinogenesis remains to be elucidated; however, the hormones are strong promoters of the disease. The growth and development of the prostate gland is controlled by androgenic sex steroids. Androgens also play a central role in the development of prostate cancer. A causal relationship between androgens and prostate cancer is supported by the sensitivity and response of many prostate cancers to hormonal therapy (Waalkes and Rehm, 1994; Bosland, 2000). The LNCaP cells are an androgen dependent human prostate cancer cell line (Horoszewicz et al., 1980). In LNCaP cells, Cd mimics the effects of androgens on cell growth (Webber et al., 1985; Martin et al., 2002) and gene expression (Martin et al., 2002). Environmentally relevant doses of $\mathrm{Cd}$ mimic androgen effects in castrated rats and mice (Martin et al., 2002). Cd produces a dose-dependent increase in the wet weight of the prostate gland and the seminal vesicle complex that is blocked by an antiandrogen, which suggests that the metal activates the androgen receptor in target tissue (Martin et al., 2002). In intact animals, Cd addition to the drinking water significantly increases the weight of the prostate and seminal vesicles and the increase in weight was not reversed upon castration (Visser and Deklerk, 1978). The aforementioned data suggest that $\mathrm{Cd}$ is also a metalloandrogen and may 
explain to some degree the heightened risk of prostate cancer associated with $\mathrm{Cd}$ exposure. 


\section{Summary}

Industrial and environmental pollutants exert adverse effects on a number of organ systems in humans and animals. Cd, a heavy metal, is one such pollutant. Although there is evidence demonstrating that adult exposure to Cd causes changes in the immune system, there are limited reports of immunomodulatory effects of prenatal exposure to $\mathrm{Cd}$. After combining studies that show prenatal $\mathrm{Cd}$ exposure causes perturbations in Shh and $\mathrm{Wnt} / \beta$-catenin signaling, and these pathways play a role in thymocyte development, it is not difficult to postulate that prenatal exposure to $\mathrm{Cd}$ may affect thymocyte development via the Shh and Wnt/ß-catenin pathways. Due to Cd's long half-life, determining whether the effects of prenatal exposure to $\mathrm{Cd}$ at birth continue to adulthood is also vital to understanding Cd's toxic mechanism. Since humans are exposed to $\mathrm{Cd}$ on a daily basis via the environment, and that pregnant women are more susceptible to Cd absorption than the rest of the population (Akesson et al., 2002), determining the effects that prenatal Cd exposure has on offspring will allow a better understanding of Cd's toxic effect on the immune response. In addition, the findings may also elucidate the teratogenic mechanism of $\mathrm{Cd}$ in other organ systems that rely on Shh and $\mathrm{Wnt} / \beta$-catenin signaling for proper development. 


\section{REFERENCES}

Achanzar, W. E., Diwan, B. A., Liu, J., Quader, S. T., Webber, M. M., and Waalkes, M. P. (2001). Cadmium-induced malignant transformation of human prostate epithelial cells. Cancer research 61, 455-458.

Achanzar, W. E., Webber, M. M., and Waalkes, M. P. (2002). Altered apoptotic gene expression and acquired apoptotic resistance in cadmium-transformed human prostate epithelial cells. Prostate 52, 236-244.

Akesson, A., Berglund, M., Schutz, A., Bjellerup, P., Bremme, K., and Vahter, M. (2002). Cadmium exposure in pregnancy and lactation in relation to iron status. American journal of public health 92, 284-287.

Akinloye, O., Arowojolu, A. O., Shittu, O. B., and Anetor, J. I. (2006). Cadmium toxicity: a possible cause of male infertility in Nigeria. Reproductive biology 6, 17-30.

Akiyama, T., Maeda, S., Yamane, S., Ogino, K., Kasai, M., Kajiura, F., Matsumoto, M., and Inoue, J. (2005). Dependence of self-tolerance on TRAF6-directed development of thymic stroma. Science (New York, N.Y 308, 248-251.

Al-Bader, A., Omu, A. E., and Dashti, H. (1999). Chronic cadmium toxicity to sperm of heavy cigarette smokers: immunomodulation by zinc. Archives of andrology 43, $135-140$.

Allen, B. L., Tenzen, T., and McMahon, A. P. (2007). The Hedgehog-binding proteins Gas1 and Cdo cooperate to positively regulate Shh signaling during mouse development. Genes \& development 21, 1244-1257.

Amit, S., Hatzubai, A., Birman, Y., Andersen, J. S., Ben-Shushan, E., Mann, M., BenNeriah, Y., and Alkalay, I. (2002). Axin-mediated CKI phosphorylation of beta- 
catenin at Ser 45: a molecular switch for the Wnt pathway. Genes \& development 16, 1066-1076.

Andaloussi, A. E., Graves, S., Meng, F., Mandal, M., Mashayekhi, M., and Aifantis, I. (2006). Hedgehog signaling controls thymocyte progenitor homeostasis and differentiation in the thymus. Nat Immunol. 7, 418-426.

Anderson, G., and Jenkinson, E. J. (2001). Lymphostromal interactions in thymic development and function. Nature reviews 1, 31-40.

Anderson, G., Jenkinson, E. J., Moore, N. C., and Owen, J. J. (1993). MHC class IIpositive epithelium and mesenchyme cells are both required for T-cell development in the thymus. Nature $362,70-73$.

Anderson, G., Owen, J. J., Moore, N. C., and Jenkinson, E. J. (1994). Thymic epithelial cells provide unique signals for positive selection of $\mathrm{CD} 4+\mathrm{CD} 8+$ thymocytes in vitro. The Journal of experimental medicine 179, 2027-2031.

Anderson, M. S., Venanzi, E. S., Klein, L., Chen, Z., Berzins, S. P., Turley, S. J., von Boehmer, H., Bronson, R., Dierich, A., Benoist, C., and Mathis, D. (2002). Projection of an immunological self shadow within the thymus by the aire protein. Science (New York, N.Y 298, 1395-1401.

Ardavin, C., Wu, L., Li, C. L., and Shortman, K. (1993). Thymic dendritic cells and T cells develop simultaneously in the thymus from a common precursor population. Nature 362, 761-763.

Arnold, J. S., Werling, U., Braunstein, E. M., Liao, J., Nowotschin, S., Edelmann, W., Hebert, J. M., and Morrow, B. E. (2006). Inactivation of Tbx1 in the pharyngeal 
endoderm results in 22q11DS malformations. Development (Cambridge, England) 133, 977-987.

Asmuss, M., Mullenders, L. H., Eker, A., and Hartwig, A. (2000). Differential effects of toxic metal compounds on the activities of Fpg and XPA, two zinc finger proteins involved in DNA repair. Carcinogenesis 21, 2097-2104.

Auger, M., Ross, J (1992). The biology of the macrophage. IRC Press, Oxford.

Bai, C. B., Auerbach, W., Lee, J. S., Stephen, D., and Joyner, A. L. (2002). Gli2, but not Gli1, is required for initial Shh signaling and ectopic activation of the Shh pathway. Development 129, 4753-4761.

Bako, G., Smith, E. S., Hanson, J., and Dewar, R. (1982). The geographical distribution of high cadmium concentrations in the environment and prostate cancer in Alberta. Canadian journal of public health 73, 92-94.

Balciunaite, G., Keller, M. P., Balciunaite, E., Piali, L., Zuklys, S., Mathieu, Y. D., Gill, J., Boyd, R., Sussman, D. J., and Hollander, G. A. (2002). Wnt glycoproteins regulate the expression of FoxN1, the gene defective in nude mice. Nature immunology 3, 1102-1108.

Barnfield, P. C., Zhang, X., Thanabalasingham, V., Yoshida, M., and Hui, C. C. (2005). Negative regulation of Gli1 and Gli2 activator function by Suppressor of fused through multiple mechanisms. Differentiation; research in biological diversity $\mathbf{7 3}$, 397-405.

Behrens, J., von Kries, J. P., Kuhl, M., Bruhn, L., Wedlich, D., Grosschedl, R., and Birchmeier, W. (1996). Functional interaction of beta-catenin with the transcription factor LEF-1. Nature 382, 638-642. 
Benbrahim-Tallaa, L., Liu, J., Webber, M. M., and Waalkes, M. P. (2007). Estrogen signaling and disruption of androgen metabolism in acquired androgenindependence during cadmium carcinogenesis in human prostate epithelial cells. Prostate 67, 135-145.

Benz, C., Heinzel, K., and Bleul, C. C. (2004). Homing of immature thymocytes to the subcapsular microenvironment within the thymus is not an absolute requirement for T cell development. European journal of immunology 34, 3652-3663.

Bhanot, P., Brink, M., Samos, C. H., Hsieh, J.-C., Wang, Y., Macke, J. P., Andrew, D., Nathans, J., and Nusse, R. (1996). A new member of the frizzled family from Drosophila functions as a Wingless receptor. Nature 382, 225-230.

Bialkowski, K., and Kasprzak, K. S. (1998). A novel assay of 8-oxo-2'-deoxyguanosine 5'-triphosphate pyrophosphohydrolase (8-oxo-dGTPase) activity in cultured cells and its use for evaluation of cadmium(II) inhibition of this activity. Nucleic acids research 26, 3194-3201.

Blackburn, C. C., and Manley, N. R. (2004). Developing a new paradigm for thymus organogenesis. Nature reviews 4, 278-289.

Blair, A., and Fraumeni, J. F. (1978). Geographic patterns of prostate cancer in the United States. Journal of the National Cancer Institute 61, 1379-1384.

Bleul, C. C., and Boehm, T. (2000). Chemokines define distinct microenvironments in the developing thymus. European journal of immunology 30, 3371-3379.

Bleul, C. C., and Boehm, T. (2005). BMP signaling is required for normal thymus development. J Immunol 175, 5213-5221. 
Bleul, C. C., Corbeaux, T., Reuter, A., Fisch, P., Monting, J. S., and Boehm, T. (2006). Formation of a functional thymus initiated by a postnatal epithelial progenitor cell. Nature 441, 992-996.

Boadi, W. Y., Yannai, S., Urbach, J., Brandes, J. M., and Summer, K. H. (1991). Transfer and accumulation of cadmium, and the level of metallothionein in perfused human placentae. Archives of toxicology 65, 318-323.

Bockman, D. E. (1997). Development of the thymus. Microscopy research and technique 38, 209-215.

Borgman, R. F., Au, B., and Chandra, R. K. (1986). Immunopathology of chronic cadmium administration in mice. International journal of immunopharmacology $\mathbf{8}$, 813-817.

Bosland, M. C. (2000). The role of steroid hormones in prostate carcinogenesis. J Natl Cancer Inst Monogr, 39-66.

Bousso, P., and Robey, E. A. (2004). Dynamic behavior of T cells and thymocytes in lymphoid organs as revealed by two-photon microscopy. Immunity 21, 349-355.

Brama, M., Gnessi, L., Basciani, S., Cerulli, N., Politi, L., Spera, G., Mariani, S., Cherubini, S., d'Abusco, A. S., Scandurra, R., and Migliaccio, S. (2007). Cadmium induces mitogenic signaling in breast cancer cell by an ERalphadependent mechanism. Molecular and cellular endocrinology 264, 102-108.

Bryson, Y., Winter, H., and Gard, S. (1980) Deficiency of immune interferon production by leukocytes of normal newborns. Cell Immunol 55,191-200. 
Bumcrot, D. A., Takada, R., and McMahon, A. P. (1995). Proteolytic processing yields two secreted forms of sonic hedgehog. Molecular and cellular biology 15, 22942303.

Burke, R., Nellen, D., Bellotto, M., Hafen, E., Senti, K. A., Dickson, B. J., and Basler, K. (1999). Dispatched, a novel sterol-sensing domain protein dedicated to the release of cholesterol-modified hedgehog from signaling cells. Cell 99, 803-815.

Candi, E., Rufini, A., Terrinoni, A., Giamboi-Miraglia, A., Lena, A. M., Mantovani, R., Knight, R., and Melino, G. (2007). DeltaNp63 regulates thymic development through enhanced expression of FgfR2 and Jag2. Proceedings of the National Academy of Sciences of the United States of America 104, 11999-12004.

Cantor, K. P., Stewart, P. A., Brinton, L. A., and Dosemeci, M. (1995). Occupational exposures and female breast cancer mortality in the United States. Journal of occupational and environmental medicine / American College of Occupational and Environmental Medicine 37, 336-348.

Capone, M., Hockett, R. D., Jr., and Zlotnik, A. (1998). Kinetics of T cell receptor beta, gamma, and delta rearrangements during adult thymic development: $\mathrm{T}$ cell receptor rearrangements are present in $\mathrm{CD} 44(+) C D 25(+)$ Pro- $\mathrm{T}$ thymocytes. Proceedings of the National Academy of Sciences of the United States of America 95, 12522-12527.

Carpenter, D. (1998). Characterization of two patched receptors for the vertebrate hedgehog protein family. Proc.Natl Acad.Sci.USA 95, 13630-13634. 
Casalino, E., Sblano, C., and Landriscina, C. (1997). Enzyme activity alteration by cadmium administration to rats: the possibility of iron involvement in lipid peroxidation. Archives of biochemistry and biophysics 346, 171-179.

Cejalvo, T., Sacedon, R., Hernandez-Lopez, C., Diez, B., Gutierrez-Frias, C., Valencia, J., Zapata, A. G., Varas, A., and Vicente, A. (2007). Bone morphogenetic protein2/4 signalling pathway components are expressed in the human thymus and inhibit early T-cell development. Immunology 121, 94-104.

Ceredig, R., Dialynas, D. P., Fitch, F. W., and MacDonald, H. R. (1983). Precursors of T cell growth factor producing cells in the thymus: ontogeny, frequency, and quantitative recovery in a subpopulation of phenotypically mature thymocytes defined by monoclonal antibody GK-1.5. The Journal of experimental medicine 158, $1654-1671$.

Ceredig, R., and Schreyer, M. (1984). Immunohistochemical localization of host and donor-derived cells in the regenerating thymus of radiation bone marrow chimeras. Thymus 6, 15-26.

Chamoun, Z., Mann, R. K., Nellen, D., von Kessler, D. P., Bellotto, M., Beachy, P. A., and Basler, K. (2001). Skinny hedgehog, an acyltransferase required for palmitoylation and activity of the hedgehog signal. Science (New York, N.Y 293, 2080-2084.

Chaumard, C., Quero, A. M., Bouley, G., Girard, F., Boudene, C., and German, A. (1983). Influence of inhaled cadmium microparticles on mouse influenza pneumonia. Environmental research 31, 428-439. 
Chen, M. H., Li, Y. J., Kawakami, T., Xu, S. M., and Chuang, P. T. (2004). Palmitoylation is required for the production of a soluble multimeric Hedgehog protein complex and long-range signaling in vertebrates. Genes \& development 18, 641-659.

Chen, Y., and Struhl, G. (1996). Dual Roles for Patched in Sequestering and Transducing Hedgehog. Cell 87, 553-563.

Chen, Y., and Struhl, G. (1998). In vivo evidence that Patched and Smoothened constitute distinct binding and transducing components of a Hedgehog receptor complex. Development 125, 4943-4948.

Ching, W., and Nusse, R. (2006). A dedicated Wnt secretion factor. Cell 125, 432-433.

Chubatsu, L. S., Gennari, M., and Meneghini, R. (1992). Glutathione is the antioxidant responsible for resistance to oxidative stress in V79 Chinese hamster fibroblasts rendered resistant to cadmium. Chemico-biological interactions 82, 99-110.

Concordet, J. P., Lewis, K. E., Moore, J. W., Goodrich, L. V., Johnson, R. L., Scott, M. P., and Ingham, P. W. (1996). Spatial regulation of a zebrafish patched homologue reflects the roles of sonic hedgehog and protein kinase A in neural tube and somite patterning. Development 122, 2835-2846.

Coto, J. A., Hadden, E. M., Sauro, M., Zorn, N., and Hadden, J. W. (1992). Interleukin 1 regulates secretion of zinc-thymulin by human thymic epithelial cells and its action on T-lymphocyte proliferation and nuclear protein kinase C. Proceedings of the National Academy of Sciences of the United States of America 89, 77527756. 
Coudreuse, D., and Korswagen, H. C. (2007). The making of Wnt: new insights into Wnt maturation, sorting and secretion. Development (Cambridge, England) 134, 3-12.

Coyle, P., Philcox, J. C., and Rofe, A. M. (1995). Metallothionein induction in cultured rat hepatocytes by arthritic rat serum, activated macrophages, interleukin-6, interleukin-11 and leukaemia inhibitory factor. Inflamm Res 44, 475-481.

Crompton, T., Outram, S. V., and Hager-Theodorides, A. L. (2007). Sonic hedgehog signalling in T-cell development and activation. Nat Rev Immunol 7, 726-735.

Crowthers, K. C., Kline, V., Giardina, C., and Lynes, M. A. (2000). Augmented humoral immune function in metallothionein-null mice. Toxicol Appl Pharmacol 166, 161172.

Dally, H., and Hartwig, A. (1997). Induction and repair inhibition of oxidative DNA damage by nickel(II) and cadmium(II) in mammalian cells. Carcinogenesis 18, 1021-1026.

Dalton, T. P., He, L., Wang, B., Miller, M. L., Jin, L., Stringer, K. F., Chang, X., Baxter, C. S., and Nebert, D. W. (2005). Identification of mouse SLC39A8 as the transporter responsible for cadmium-induced toxicity in the testis. Proceedings of the National Academy of Sciences of the United States of America 102, 34013406.

Dan, G., Lall, S. B., and Rao, D. N. (2000). Humoral and cell mediated immune response to cadmium in mice. Drug Chem Toxicol. 23, 349-360.

Daniels, D. L., and Weis, W. I. (2005). Beta-catenin directly displaces Groucho/TLE repressors from Tcf/Lef in Wnt-mediated transcription activation. Nature structural \& molecular biology 12, 364-371. 
Daniels, M. J., Menache, M. G., Burleson, G. R., Graham, J. A., and Selgrade, M. K. (1987). Effects of $\mathrm{NiCl} 2$ and $\mathrm{CdCl} 2$ on susceptibility to murine cytomegalovirus and virus-augmented natural killer cell and interferon responses. Fundam Appl Toxicol 8, 443-453.

Daum, J. R., Shepherd, D. M., and Noelle, R. J. (1993). Immunotoxicology of cadmium and mercury on B-lymphocytes--I. Effects on lymphocyte function. Int $\mathrm{J}$ Immunopharmacol 15, 383-394.

de la Fuente, H., Portales-Perez, D., Baranda, L., Diaz-Barriga, F., Saavedra-Alanis, V., Layseca, E., and Gonzalez-Amaro, R. (2002). Effect of arsenic, cadmium and lead on the induction of apoptosis of normal human mononuclear cells. Clinical and experimental immunology 129, 69-77.

De, S. K., Dey, S. K., and Andrews, G. K. (1990). Cadmium teratogenicity and its relationship with metallothionein gene expression in midgestation mouse embryos. Toxicology 64, 89-104.

De, S. K., Paria, B. C., Dey, S. K., and Andrews, G. K. (1993). Stage-specific effects of cadmium on preimplantation embryo development and implantation in the mouse. Toxicology 80, 13-25.

Derbinski, J., Schulte, A., Kyewski, B., and Klein, L. (2001). Promiscuous gene expression in medullary thymic epithelial cells mirrors the peripheral self. Nature immunology 2, 1032-1039.

Descotes, J. (1992). Immunotoxicology of cadmium. IARC Sci Publ., 385-390.

Dik, W. A., Pike-Overzet, K., Weerkamp, F., de Ridder, D., de Haas, E. F., Baert, M. R., van der Spek, P., Koster, E. E., Reinders, M. J., van Dongen, J. J., Langerak, A. 
W., and Staal, F. J. (2005). New insights on human T cell development by quantitative $\mathrm{T}$ cell receptor gene rearrangement studies and gene expression profiling. The Journal of experimental medicine 201, 1715-1723.

Ding, A. H., Nathan, C. F., and Stuehr, D. J. (1988). Release of reactive nitrogen intermediates and reactive oxygen intermediates from mouse peritoneal macrophages. Comparison of activating cytokines and evidence for independent production. J Immunol 141, 2407-2412.

Dong, S., Shen, H. M., and Ong, C. N. (2001). Cadmium-induced apoptosis and phenotypic changes in mouse thymocytes. Molecular and cellular biochemistry 222, 11-20.

Dubrow, R., and Wegman, D. H. (1984). Cancer and occupation in Massachusetts: a death certificate study. American journal of industrial medicine 6, 207-230.

Dudley, E. C., Petrie, H. T., Shah, L. M., Owen, M. J., and Hayday, A. C. (1994). T cell receptor beta chain gene rearrangement and selection during thymocyte development in adult mice. Immunity 1, 83-93.

El-Ashmawy, I. M., and Youssef, S. A. (1999). The antagonistic effect of chlorpromazine on cadmium toxicity. Toxicol Appl Pharmacol 161, 34-39.

Elghany, N. A., Schumacher, M. C., Slattery, M. L., West, D. W., and Lee, J. S. (1990). Occupation, cadmium exposure, and prostate cancer. Epidemiology (Cambridge, Mass 1, 107-115.

Elinder, C. G., Lind, B., Kjellstrom, T., Linnman, L., and Friberg, L. (1976). Cadmium in kidney cortex, liver, and pancreas from Swedish autopsies. Estimation of 
biological half time in kidney cortex, considering calorie intake and smoking habits. Archives of environmental health 31, 292-302.

Fang, M. Z., Mar, W. C., and Cho, M. H. (2001). Cadmium-induced alterations of connexin expression in the promotion stage of in vitro two-stage transformation. Toxicology 161, 117-127.

Fatur, T., Lah, T. T., and Filipic, M. (2003). Cadmium inhibits repair of UV-, methyl methanesulfonate- and N-methyl-N-nitrosourea-induced DNA damage in Chinese hamster ovary cells. Mutation research 529, 109-116.

Feng, L., Xia, Y., Garcia, G. E., Hwang, D., and Wilson, C. B. (1995). Involvement of reactive oxygen intermediates in cyclooxygenase-2 expression induced by interleukin-1, tumor necrosis factor-alpha, and lipopolysaccharide. The Journal of clinical investigation 95, 1669-1675.

Feuston, M. H., and Scott, W. J., Jr. (1985). Cadmium-induced forelimb ectrodactyly: a proposed mechanism of teratogenesis. Teratology 32, 407-419.

Flora, S. J., Mittal, M., and Mehta, A. (2008). Heavy metal induced oxidative stress \& its possible reversal by chelation therapy. The Indian journal of medical research 128, 501-523.

Fort, D. J., McLaughlin, D. W., Rogers, R. L., and Buzzard, B. O. (2002). Effect of endocrine disrupting chemicals on germinal vesicle breakdown in Xenopus in vitro. Drug and chemical toxicology 25, 293-308.

Fort, D. J., Stover, E. L., Bantle, J. A., Dumont, J. N., and Finch, R. A. (2001). Evaluation of a reproductive toxicity assay using Xenopus laevis: boric acid, cadmium and ethylene glycol monomethyl ether. J Appl Toxicol 21, 41-52. 
Frery, N., Nessmann, C., Girard, F., Lafond, J., Moreau, T., Blot, P., Lellouch, J., and Huel, G. (1993). Environmental exposure to cadmium and human birthweight. Toxicology. 79, 109-118.

Friberg, L. (1986). Cadmium and health: a toxicological and epidemiological appraisal. CRC Press, Boca Raton, Fl.

Fujimaki, H., Ishido, M., and Nohara, K. (2000). Induction of apoptosis in mouse thymocytes by cadmium. Toxicology Letters 115, 99-105.

Fujimaki, H., Murakami, M., and Kubota, K. (1982). In vitro evaluation of cadmiuminduced augmentation of the antibody response. Toxicol Appl Pharmacol 62, 288-293.

Galan, A., Garcia-Bermejo, L., Troyano, A., Vilaboa, N. E., Fernandez, C., de Blas, E., and Aller, P. (2001). The role of intracellular oxidation in death induction (apoptosis and necrosis) in human promonocytic cells treated with stress inducers (cadmium, heat, X-rays). European journal of cell biology 80, 312-320.

Gale, T. F., and Layton, W. M. (1980). The susceptibility of inbred strains of hamsters to cadmium-induced embryotoxicity. Teratology 21, 181-186.

Galicia-Garcia, V., Rojas-Lopez, M., Rojas, R., Olaiz, G., and Rios, C. (1997). Cadmium levels in maternal, cord and newborn blood in Mexico City. Toxicol Lett 91, 5761.

Gallegos, A. M., and Bevan, M. J. (2004). Central tolerance to tissue-specific antigens mediated by direct and indirect antigen presentation. The Journal of experimental medicine 200, 1039-1049. 
Gallet, A., Ruel, L., Staccini-Lavenant, L., and Therond, P. P. (2006). Cholesterol modification is necessary for controlled planar long-range activity of Hedgehog in Drosophila epithelia. Development 133, 407-418.

Gao, Z. H., Seeling, J. M., Hill, V., Yochum, A., and Virshup, D. M. (2002). Casein kinase I phosphorylates and destabilizes the beta-catenin degradation complex. Proceedings of the National Academy of Sciences of the United States of America 99, 1182-1187.

Gardner, D. E., Miller, F. J., Illing, J. W., and Kirtz, J. M. (1977). Alterations in bacterial defense mechanisms of the lung induced by inhalation of cadmium. Bulletin europeen de physiopathologie respiratoire 13, 157-174.

Godfrey, D. I., Kennedy, J., Mombaerts, P., Tonegawa, S., and Zlotnik, A. (1994). Onset of TCR-beta gene rearrangement and role of TCR-beta expression during CD3CD4-CD8- thymocyte differentiation. J Immunol 152, 4783-4792.

Godfrey, D. I., Kennedy, J., Suda, T., and Zlotnik, A. (1993). A developmental pathway involving four phenotypically and functionally distinct subsets of CD3-CD4-CD8triple-negative adult mouse thymocytes defined by CD44 and CD25 expression. J Immunol 150, 4244-4252.

Goering, P. L., and Klaassen, C. D. (1983). Altered subcellular distribution of cadmium following cadmium pretreatment: possible mechanism of tolerance to cadmiuminduced lethality. Toxicol Appl Pharmacol 70, 195-203.

Gounari, F., Aifantis, I., Khazaie, K., Hoeflinger, S., Harada, N., Taketo, M. M., and von Boehmer, H. (2001). Somatic activation of beta-catenin bypasses pre-TCR 
signaling and TCR selection in thymocyte development. Nature immunology $\mathbf{2}$, 863-869.

Goux, D., Coudert, J. D., Maurice, D., Scarpellino, L., Jeannet, G., Piccolo, S., Weston, K., Huelsken, J., and Held, W. (2005). Cooperating pre-T-cell receptor and TCF1-dependent signals ensure thymocyte survival. Blood 106, 1726-1733.

Goyer, R. A., and Cherian, M. G. (1992). Role of metallothionein in human placenta and rats exposed to cadmium. IARC scientific publications, 239-247.

Goyer, R. A., Liu, J., and Waalkes, M. P. (2004). Cadmium and cancer of prostate and testis. Biometals 17, 555-558.

Graf, D., Nethisinghe, S., Palmer, D. B., Fisher, A. G., and Merkenschlager, M. (2002). The developmentally regulated expression of Twisted gastrulation reveals a role for bone morphogenetic proteins in the control of $\mathrm{T}$ cell development. The Journal of experimental medicine 196, 163-171.

Guerrero, I., and Chiang, C. (2007). A conserved mechanism of Hedgehog gradient formation by lipid modifications. Trends in cell biology 17, 1-5.

Guidos, C. J. (2006). Synergy between the pre-T cell receptor and Notch: cementing the alphabeta lineage choice. The Journal of experimental medicine 203, 2233-2237.

Hager-Theodorides, A. L., Dessens, J. T., Outram, S. V., and Crompton, T. (2005). The transcription factor Gli3 regulates differentiation of fetal CD4- CD8- doublenegative thymocytes. Blood 106, 1296-1304.

Hager-Theodorides, A. L., Outram, S. V., Shah, D. K., Sacedon, R., Shrimpton, R. E., Vicente, A., Varas, A., and Crompton, T. (2002). Bone morphogenetic protein 2/4 signaling regulates early thymocyte differentiation. J Immunol 169, 5496-5504. 
Haks, M. C., Lefebvre, J. M., Lauritsen, J. P., Carleton, M., Rhodes, M., Miyazaki, T., Kappes, D. J., and Wiest, D. L. (2005). Attenuation of gammadeltaTCR signaling efficiently diverts thymocytes to the alphabeta lineage. Immunity 22, 595-606.

Haks, M. C., Oosterwegel, M. A., Blom, B., Spits, H. M., and Kruisbeek, A. M. (1999). Cell-fate decisions in early $\mathrm{T}$ cell development: regulation by cytokine receptors and the pre-TCR. Seminars in immunology 11, 23-37.

Hamer, D. H. (1986). Metallothionein. Annual review of biochemistry 55, 913-951.

Hardy, K., Warner, A., Winston, R. M., and Becker, D. L. (1996). Expression of intercellular junctions during preimplantation development of the human embryo. Molecular human reproduction 2, 621-632.

Hart, B. A., Lee, C. H., Shukla, G. S., Shukla, A., Osier, M., Eneman, J. D., and Chiu, J. F. (1999). Characterization of cadmium-induced apoptosis in rat lung epithelial cells: evidence for the participation of oxidant stress. Toxicology $133,43-58$.

Hartwig, A., and Schwerdtle, T. (2002). Interactions by carcinogenic metal compounds with DNA repair processes: toxicological implications. Toxicol Lett 127, 47-54.

Hayes, S. M., Li, L., and Love, P. E. (2005). TCR signal strength influences alphabeta/gammadelta lineage fate. Immunity 22, 583-593.

Hemdan, N. Y., Emmrich, F., Sack, U., Wichmann, G., Lehmann, J., Adham, K., and Lehmann, I. (2006). The in vitro immune modulation by cadmium depends on the way of cell activation. Toxicology. .

Herzer, U., Crocoll, A., Barton, D., Howells, N., and Englert, C. (1999). The Wilms tumor suppressor gene wt1 is required for development of the spleen. Curr Biol 9, 837840. 
Hoffmans, R., Stadeli, R., and Basler, K. (2005). Pygopus and legless provide essential transcriptional coactivator functions to armadillo/beta-catenin. Curr Biol 15, 12071211.

Holt, D., and Webb, M. (1987). Teratogenicity of ionic cadmium in the Wistar rat. Archives of toxicology 59, 443-447.

Horoszewicz, J. S., Leong, S. S., Chu, T. M., Wajsman, Z. L., Friedman, M., Papsidero, L., Kim, U., Chai, L. S., Kakati, S., Arya, S. K., and Sandberg, A. A. (1980). The LNCaP cell line--a new model for studies on human prostatic carcinoma. Progress in clinical and biological research 37, 115-132.

Huang, Z., Xie, H., loannidis, V., Held, W., Clevers, H., Sadim, M. S., and Sun, Z. (2006). Transcriptional regulation of CD4 gene expression by T cell factor-1/betacatenin pathway. J Immunol 176, 4880-4887.

Huel, G., Boudene, C., and Ibrahim, M. A. (1981). Cadmium and lead content of maternal and newborn hair: relationship to parity, birth weight, and hypertension. Archives of environmental health 36, 221-227.

Huesmann, M., Scott, B., Kisielow, P., and von Boehmer, H. (1991). Kinetics and efficacy of positive selection in the thymus of normal and $T$ cell receptor transgenic mice. Cell 66, 533-540.

IARC (2004). Monographs on the Evaluation of Carcinogenic Risk of Chemicals to Humans. IARC, Lyon, France.

Ikeda, S., Kishida, S., Yamamoto, H., Murai, H., Koyama, S., and Kikuchi, A. (1998). Axin, a negative regulator of the Wnt signaling pathway, forms a complex with 
GSK-3beta and beta-catenin and promotes GSK-3beta-dependent phosphorylation of beta-catenin. The EMBO journal 17, 1371-1384.

Ingham, P. W., and McMahon, A. P. (2001). Hedgehog signaling in animal development: paradigms and principles. Genes and Development 15, 30593087.

Irving, B. A., Alt, F. W., and Killeen, N. (1998). Thymocyte development in the absence of pre-T cell receptor extracellular immunoglobulin domains. Science (New York, N.Y 280, 905-908.

Ismaili, J., Antica, M., and Wu, L. (1996). CD4 and CD8 expression and T cell antigen receptor gene rearrangement in early intrathymic precursor cells. European journal of immunology 26, 731-737.

Jacquillet, G., Barbier, O., Rubera, I., Tauc, M., Borderie, A., Namorado, M. C., Martin, D., Sierra, G., Reyes, J. L., Poujeol, P., and Cougnon, M. (2007). Cadmium causes delayed effects on renal function in the offspring of cadmiumcontaminated pregnant female rats. American journal of physiology 293, F14501460.

Jarup, L., Berglund, M., Elinder, C. G., Nordberg, G., and Vahter, M. (1998). Health effects of cadmium exposure--a review of the literature and a risk estimate. Scandinavian journal of work, environment \& health 24 Suppl 1, 1-51.

Jeong, S. H., Habeebu, S. S., and Klaassen, C. D. (2000). Cadmium decreases gap junctional intercellular communication in mouse liver. Toxicol Sci 57, 156-166. 
Jin, T., Lu, J., and Nordberg, M. (1998). Toxicokinetics and biochemistry of cadmium with special emphasis on the role of metallothionein. Neurotoxicology. 19, 529535.

Johnson, M. D., Kenney, N., Stoica, A., Hilakivi-Clarke, L., Singh, B., Chepko, G., Clarke, R., Sholler, P. F., Lirio, A. A., Foss, C., Reiter, R., Trock, B., Paik, S., and Martin, M. B. (2003). Cadmium mimics the in vivo effects of estrogen in the uterus and mammary gland. Nature medicine $9,1081-1084$.

Jotereau, F., Heuze, F., Salomon-Vie, V., and Gascan, H. (1987). Cell kinetics in the fetal mouse thymus: precursor cell input, proliferation, and emigration. $\mathrm{J}$ Immunol 138, $1026-1030$.

Kagawa, J. (1994). Atmospheric pollution due to mobile sources and effects on human health in Japan. Environ Health Perspect 102 Suppl 4, 93-99.

Kagi, J. H., and Schaffer, A. (1988). Biochemistry of metallothionein. Biochemistry 27, 8509-8515.

Kajiura, F., Sun, S., Nomura, T., Izumi, K., Ueno, T., Bando, Y., Kuroda, N., Han, H., Li, Y., Matsushima, A., Takahama, Y., Sakaguchi, S., Mitani, T., and Matsumoto, M. (2004). NF-kappa B-inducing kinase establishes self-tolerance in a thymic stroma-dependent manner. J Immunol 172, 2067-2075.

Kawai, M., Swan, K. F., Green, A. E., Edwards, D. E., Anderson, M. B., and Henson, M. C. (2002). Placental Endocrine Disruption Induced by Cadmium: Effects on P450 Cholesterol Side-Chain Cleavage and 3\{beta\}-Hydroxysteroid Dehydrogenase Enzymes in Cultured Human Trophoblasts. Biol Reprod 67, 178-183. 
Kidder, G. M., and Winterhager, E. (2001). Intercellular communication in preimplantation development: the role of gap junctions. Front Biosci 6, D731-736.

Kim, B. Y., Han, M. J., and Chung, A. S. (2001). Effects of reactive oxygen species on proliferation of Chinese hamster lung fibroblast (V79) cells. Free radical biology \& medicine 30, 686-698.

Kinoshita, D., Hirota, F., Kaisho, T., Kasai, M., Izumi, K., Bando, Y., Mouri, Y., Matsushima, A., Niki, S., Han, H., Oshikawa, K., Kuroda, N., Maegawa, M., Irahara, M., Takeda, K., Akira, S., and Matsumoto, M. (2006). Essential role of IkappaB kinase alpha in thymic organogenesis required for the establishment of self-tolerance. J Immunol 176, 3995-4002.

Kipling, M. D. a. W., J.A.H. (1967). Cadmium and prostatic carcinoma. Lancet 28, 199204.

Klaassen, C. D. (1978). Effect of metallothionein on hepatic disposition of metals. The American journal of physiology 234, E47-53.

Klaassen, C. D., Liu, J., and Choudhuri, S. (1999a). Metallothionein: an intracellular protein to protect against cadmium toxicity. Annual review of pharmacology and toxicology 39, 267-294.

Klaassen, C. D., Liu, J., and Choudhuri, S. (1999b). METALLOTHIONEIN: An Intracellular Protein to Protect Against Cadmium Toxicity, pp. 267-294.

Koebernick, K., and Pieler, T. (2002). Gli-type zinc finger proteins as bipotential transducers of Hedgehog signaling. Differentiation; research in biological diversity $70,69-76$. 
Koller, L. D., Exon, J. H., and Roan, J. G. (1976). Humoral antibody response in mice after single dose exposure to lead or cadmium. Proceedings of the Society for Experimental Biology and Medicine. Society for Experimental Biology and Medicine (New York, N.Y 151, 339-342.

Koller, L. D., and Roan, J. G. (1977). Effects of lead and cadmium on mouse peritoneal macrophages. Journal of the Reticuloendothelial Society 21, 7-12.

Konecki, J., Blazejowski, J., Slowinski, J., and Helewski, K. (2000). Influence of chronic cadmium exposure during pregnancy on DNA synthesis in different organs of rat offspring. Med Sci Monit 6, 1077-1081.

Kotsonis, F. N., and Klaassen, C. D. (1977). Toxicity and distribution of cadmium administered to rats at sublethal doses. Toxicol Appl Pharmacol 41, 667-680.

Krocova, Z., Macela, A., Kroca, M., and Hernychova, L. (2000). The immunomodulatory effect(s) of lead and cadmium on the cells of immune system in vitro. Toxicol In Vitro. 14, 33-40.

Kurobe, H., Liu, C., Ueno, T., Saito, F., Ohigashi, I., Seach, N., Arakaki, R., Hayashi, Y., Kitagawa, T., Lipp, M., Boyd, R. L., and Takahama, Y. (2006). CCR7-dependent cortex-to-medulla migration of positively selected thymocytes is essential for establishing central tolerance. Immunity 24, 165-177.

Kyewski, B. A., Momburg, F., and Schirrmacher, V. (1987). Phenotype of stromal cellassociated thymocytes in situ is compatible with selection of the T cell repertoire at an "immature" stage of thymic $\mathrm{T}$ cell differentiation. European journal of immunology 17, 961-967. 
Lafuente, A., Gonzalez-Carracedo, A., Romero, A., and Esquifino, A. I. (2003). Effect of cadmium on lymphocyte subsets distribution in thymus and spleen. J Physiol Biochem. 59, 43-48.

Lafuente, A., Gonzalez-Carracedol, A., and Esquifino, A. I. (2004). Differential effects of cadmium on blood lymphocyte subsets. Biometals. 17, 451-456.

Lagerkvist, B. J., Nordberg, G. F., Soderberg, H. A., Ekesrydh, S., Englyst, V., Gustavsson, M., Gustavsson, N. O., and Wiklund, D. E. (1992). Placental transfer of cadmium. IARC Sci Publ., 287-291.

Laskin, D. L., and Pendino, K. J. (1995). Macrophages and inflammatory mediators in tissue injury. Annual review of pharmacology and toxicology 35, 655-677.

Lauwerys, R., Buchet, J. P., Roels, H., Bernard, A., and Gennart, J. P. (1986). [Biological aspects of occupational exposure to cadmium and several other metals]. Revue d'epidemiologie et de sante publique 34, 280-285.

Layton, W. M., Jr., and Layton, M. W. (1979). Cadmium induced limb defects in mice: strain associated differences in sensitivity. Teratology. 19, 229-235.

Lee, J. J., Ekker, S. C., von Kessler, D. P., Porter, J. A., Sun, B. I., and Beachy, P. A. (1994). Autoproteolysis in hedgehog protein biogenesis. Science (New York, N.Y 266, 1528-1537.

Lehman, L. D., and Klaassen, C. D. (1986). Dosage-dependent disposition of cadmium administered orally to rats. Toxicol Appl Pharmacol 84, 159-167.

Leibbrandt, M. E., and Koropatnick, J. (1994). Activation of human monocytes with lipopolysaccharide induces metallothionein expression and is diminished by zinc. Toxicology and applied pharmacology 124, 72-81. 
Lemarie, A., Lagadic-Gossmann, D., Morzadec, C., Allain, N., Fardel, O., and Vernhet, L. (2004). Cadmium induces caspase-independent apoptosis in liver Hep3B cells: role for calcium in signaling oxidative stress-related impairment of mitochondria and relocation of endonuclease $G$ and apoptosis-inducing factor. Free radical biology \& medicine 36, 1517-1531.

Leoni, G., Bogliolo, L., Deiana, G., Berlinguer, F., Rosati, I., Pintus, P. P., Ledda, S., and Naitana, S. (2002). Influence of cadmium exposure on in vitro ovine gamete dysfunction. Reproductive toxicology (Elmsford, N.Y 16, 371-377.

Leslie, E. M., Liu, J., Klaassen, C. D., and Waalkes, M. P. (2006). Acquired cadmium resistance in metallothionein-I/II(-/-) knockout cells: role of the T-type calcium channel Cacnalpha1G in cadmium uptake. Molecular pharmacology 69, 629-639.

Lettice, L., Hecksher-Sorensen, J., and Hill, R. (2001). The role of Bapx1 (Nkx3.2) in the development and evolution of the axial skeleton. Journal of anatomy 199, 181187.

Li, C. L., Toda, K., Saibara, T., Zhang, T., Ono, M., Iwasaki, S., Maeda, T., Okada, T., Hayashi, Y., Enzan, H., Shizuta, Y., and Onishi, S. (2002a). Estrogen deficiency results in enhanced expression of Smoothened of the Hedgehog signaling in the thymus and affects thymocyte development. International immunopharmacology 2, 823-833.

Li, C. L., Zhang, T., Saibara, T., Nemoto, Y., Ono, M., Akisawa, N., Iwasaki, S., Maeda, T., and Onishi, S. (2002b). Thymosin alpha1 accelerates restoration of T cellmediated neutralizing antibody response in immunocompromised hosts. International immunopharmacology 2, 39-46. 
Licona-Limon, P., and Soldevila, G. (2007). The role of TGF-beta superfamily during T cell development: new insights. Immunology letters 109, 1-12.

Lienesch, L. A., Dumont, J. N., and Bantle, J. A. (2000). The effect of cadmium on oogenesis in Xenopus laevis. Chemosphere 41, 1651-1658.

Lind, E. F., Prockop, S. E., Porritt, H. E., and Petrie, H. T. (2001). Mapping precursor movement through the postnatal thymus reveals specific microenvironments supporting defined stages of early lymphoid development. The Journal of experimental medicine 194, 127-134.

Liu, C., Saito, F., Liu, Z., Lei, Y., Uehara, S., Love, P., Lipp, M., Kondo, S., Manley, N., and Takahama, Y. (2006). Coordination between CCR7- and CCR9-mediated chemokine signals in prevascular fetal thymus colonization. Blood 108, 25312539.

Liu, J., Liu, Y., Habeebu, S. S., and Klaassen, C. D. (1999). Metallothionein-null mice are highly susceptible to the hematotoxic and immunotoxic effects of chronic $\mathrm{CdCl} 2$ exposure. Toxicol Appl Pharmacol 159, 98-108.

Liu, J., Liu, Y., Michalska, A. E., Choo, K. H., and Klaassen, C. D. (1996). Distribution and retention of cadmium in metallothionein I and II null mice. Toxicol App/ Pharmacol 136, 260-268.

Livak, F., Tourigny, M., Schatz, D. G., and Petrie, H. T. (1999). Characterization of TCR gene rearrangements during adult murine T cell development. J Immunol 162, $2575-2580$.

Logan, C. Y., and Nusse, R. (2004). The Wnt signaling pathway in development and disease. Annual review of cell and developmental biology 20, 781-810. 
Loose, L. D., Silkworth, J. B., and Warrington, D. (1978). Cadmium-induced phagocyte cytotoxicity. Bull Environ Contam Toxicol 20, 582-588.

Lu, J., Chang, P., Richardson, J. A., Gan, L., Weiler, H., and Olson, E. N. (2000). The basic helix-loop-helix transcription factor capsulin controls spleen organogenesis. Proceedings of the National Academy of Sciences of the United States of America 97, 9525-9530.

Lundberg, K., and Shortman, K. (1994). Small cortical thymocytes are subject to positive selection. The Journal of experimental medicine 179, 1475-1483.

Lynes, M. A., and Yin, X. (2006). Metallothionein and anti-metallothionein, complementary elements of cadmium-induced renal disease. Toxicol Sci. 91, 13.

Mackova, N. O., Lenikova, S., Fedorocko, P., Brezani, P., and Fedorockova, A. (1996). Effects of cadmium on haemopoiesis in irradiated and non-irradiated mice: 2. Relationship to the number of circulating blood cells and haemopoiesis. Physiological research / Academia Scientiarum Bohemoslovaca 45, 101-106.

Manley, N. R. (2000). Thymus organogenesis and molecular mechanisms of thymic epithelial cell differentiation. Seminars in immunology 12, 421-428.

Manley, N. R., Selleri, L., Brendolan, A., Gordon, J., and Cleary, M. L. (2004). Abnormalities of caudal pharyngeal pouch development in Pbx1 knockout mice mimic loss of Hox3 paralogs. Developmental biology 276, 301-312.

Mann, R. K., and Beachy, P. A. (2004). Novel lipid modifications of secreted protein signals. Annual review of biochemistry 73, 891-923. 
Marigo, V., Davey, R. A., Zuo, Y., Cunningham, J. M., and Tabin, C. J. (1996). Biochemical evidence that patched is the Hedgehog receptor. Nature 384, 176179.

Martin, M. B., Voeller, H. J., Gelmann, E. P., Lu, J., Stoica, E. G., Hebert, E. J., Reiter, R., Singh, B., Danielsen, M., Pentecost, E., and Stoica, A. (2002). Role of cadmium in the regulation of AR gene expression and activity. Endocrinology $143,263-275$.

Matise, M. P., and Joyner, A. L. (1999). Gli genes in development and cancer. Oncogene 18, 7852-7859.

Matsuzaki, Y., Gyotoku, J., Ogawa, M., Nishikawa, S., Katsura, Y., Gachelin, G., and Nakauchi, H. (1993). Characterization of c-kit positive intrathymic stem cells that are restricted to lymphoid differentiation. The Journal of experimental medicine $178,1283-1292$.

Menoud, P. A., and Schowing, J. (1987). A preliminary study of the mechanisms of cadmium teratogenicity in chick embryo after direct action. Journal de toxicologie clinique et experimentale 7, 77-84.

Meplan, C., Mann, K., and Hainaut, P. (1999). Cadmium induces conformational modifications of wild-type p53 and suppresses p53 response to DNA damage in cultured cells. The Journal of biological chemistry 274, 31663-31670.

Messerle, K., and Webster, W. S. (1982). The classification and development of cadmium-induced limb defects in mice. Teratology 25, 61-70. 
Meydani, S. N., Wu, D., Santos, M. S., and Hayek, M. G. (1995). Antioxidants and immune response in aged persons: overview of present evidence. The American journal of clinical nutrition 62, 1462S-1476S.

Michie, A. M., and Zuniga-Pflucker, J. C. (2002). Regulation of thymocyte differentiation: pre-TCR signals and beta-selection. Seminars in immunology 14, 311-323.

Miller, J. F., and Osoba, D. (1967). Current concepts of the immunological function of the thymus. Physiological reviews 47, 437-520.

Miller, J. R. (2002). The Wnts. Genome biology 3, REVIEWS3001.

Minetti, A., and Reale, C. A. (2006). Sensorimotor developmental delays and lower anxiety in rats prenatally exposed to cadmium. J Appl Toxicol 26, 35-41.

Misra, U. K., Gawdi, G., Akabani, G., and Pizzo, S. V. (2002). Cadmium-induced DNA synthesis and cell proliferation in macrophages: the role of intracellular calcium and signal transduction mechanisms. Cell Signal. 14, 327-340.

Misslitz, A., Bernhardt, G., and Forster, R. (2006). Trafficking on serpentines: molecular insight on how maturating $T$ cells find their winding paths in the thymus. Immunological reviews 209, 115-128.

Misslitz, A., Pabst, O., Hintzen, G., Ohl, L., Kremmer, E., Petrie, H. T., and Forster, R. (2004). Thymic T cell development and progenitor localization depend on CCR7. The Journal of experimental medicine 200, 481-491.

Mlynarcikova, A., Fickova, M., and Scsukova, S. (2005). Ovarian intrafollicular processes as a target for cigarette smoke components and selected environmental reproductive disruptors. Endocrine regulations 39, 21-32. 
Mo, R., Freer, A. M., Zinyk, D. L., Crackower, M. A., Michaud, J., Heng, H. H., Chik, K. W., Shi, X. M., Tsui, L. C., Cheng, S. H., Joyner, A. L., and Hui, C. (1997). Specific and redundant functions of Gli2 and Gli3 zinc finger genes in skeletal patterning and development. Development 124, 113-123.

Moncada, S., Palmer, R. M., and Higgs, E. A. (1991). Nitric oxide: physiology, pathophysiology, and pharmacology. Pharmacological reviews 43, 109-142.

Moore-Scott, B. A., and Manley, N. R. (2005). Differential expression of Sonic hedgehog along the anterior-posterior axis regulates patterning of pharyngeal pouch endoderm and pharyngeal endoderm-derived organs. Developmental biology 278, 323-335.

Moore, T. A., and Zlotnik, A. (1995). T-cell lineage commitment and cytokine responses of thymic progenitors. Blood 86, 1850-1860.

Morselt, A. F. W., Leene, W., DeGroot, C., Kipp, J. B. A., Evers, M., Roelofsen, A. M., and Bosch, K. S. (1988). Differences in immunological susceptibility to cadmium toxicity between two rat strains as demonstrated with cell biological methods. Effect of cadmium on DNA synthesis of thymus lymphocytes. Toxicology 48, 127139.

Motoyama, J., Takabatake, T., Takeshima, K., and Hui, C. (1998). Ptch2, a second mouse Patched gene is co-expressed with Sonic hedgehog. Nature genetics $\mathbf{1 8}$, 104-106.

Mulroy, T., McMahon, J. A., Burakoff, S. J., McMahon, A. P., and Sen, J. (2002). Wnt-1 and Wnt-4 regulate thymic cellularity. European journal of immunology 32, 967971. 
Mulroy, T., Xu, Y., and Sen, J. M. (2003). beta-Catenin expression enhances generation of mature thymocytes. International immunology 15, 1485-1494.

Nehls, M., Kyewski, B., Messerle, M., Waldschutz, R., Schuddekopf, K., Smith, A. J., and Boehm, T. (1996). Two genetically separable steps in the differentiation of thymic epithelium. Science (New York, N.Y 272, 886-889.

Nishijo, M., Nakagawa, H., Honda, R., Tanebe, K., Saito, S., Teranishi, H., and Tawara, K. (2002). Effects of maternal exposure to cadmium on pregnancy outcome and breast milk. Occup.Environ.Med. 59, 394-396.

Nishijo, M., Tawara, K., Honda, R., Nakagawa, H., Tanebe, K., and Saito, S. (2004). Relationship between newborn size and mother's blood cadmium levels, Toyama, Japan. Arch.Environ.Health. 59, 22-25.

Nordberg, G. F. (2006). Lung cancer and exposure to environmental cadmium. Lancet Oncol. 7, 99-101.

Nordberg, M., Jin, T., and Nordberg, G. F. (1992). Cadmium, metallothionein and renal tubular toxicity. IARC scientific publications, 293-297.

Novak, A., and Dedhar, S. (1999). Signaling through beta-catenin and Lef/Tcf. Cell Mol Life Sci 56, 523-537.

O'Banion, M. K. (1999). Cyclooxygenase-2: molecular biology, pharmacology, and neurobiology. Critical reviews in neurobiology 13, 45-82.

Ochi, T., Takahashi, K., and Ohsawa, M. (1987). Indirect evidence for the induction of a prooxidant state by cadmium chloride in cultured mammalian cells and a possible mechanism for the induction. Mutation research 180, 257-266. 
Ognjanovic, B. I., Pavlovic, S. Z., Maletic, S. D., Zikic, R. V., Stajn, A. S., Radojicic, R. M., Saicic, Z. S., and Petrovic, V. M. (2003). Protective influence of vitamin E on antioxidant defense system in the blood of rats treated with cadmium. Physiological research / Academia Scientiarum Bohemoslovaca 52, 563-570.

Ohsawa, M., Masuko-Sato, K., Takahashi, K., and Otsuka, F. (1986). Strain differences in cadmium-mediated suppression of lymphocyte proliferation in mice. Toxicol Appl.Pharmacol. 84, 379-388.

Olafson, R. W. (1985). Thymus metallothionein: regulation of zinc-thionein in the aging mouse. Canadian journal of biochemistry and cell biology = Revue canadienne de biochimie et biologie cellulaire 63, 91-95.

Olsson, I. M., Bensryd, I., Lundh, T., Ottosson, H., Skerfving, S., and Oskarsson, A. (2002). Cadmium in blood and urine--impact of sex, age, dietary intake, iron status, and former smoking--association of renal effects. Environ Health Perspect $110,1185-1190$.

Othumpangat, S., Kashon, M., and Joseph, P. (2005). Eukaryotic translation initiation factor $4 \mathrm{E}$ is a cellular target for toxicity and death due to exposure to cadmium chloride. The Journal of biological chemistry 280, 25162-25169.

Outram, S. V., Hager-Theodorides, A. L., Shah, D. K., Rowbotham, N. J., Drakopoulou, E., Ross, S. E., Lanske, B., Dessens, J. T., and Crompton, T. (2008). Indian hedgehog (Ihh) both promotes and restricts thymocyte differentiation. Blood, blood-2008-2003-144840. 
Outram, S. V., Varas, A., Pepicelli, C. V., and Crompton, T. (2000). Hedgehog signaling regulates differentiation from double-negative to double-positive thymocyte. Immunity. 13, 187-197.

Owen, J. J., McLoughlin, D. E., Suniara, R. K., and Jenkinson, E. J. (2000). The role of mesenchyme in thymus development. Current topics in microbiology and immunology 251, 133-137.

Paksy, K., Rajczy, K., Forgacs, Z., Lazar, P., Bernard, A., Gati, I., and Kaali, G. S. (1997a). Effect of cadmium on morphology and steroidogenesis of cultured human ovarian granulosa cells. J Appl Toxicol 17, 321-327.

Paksy, K., Varga, B., Horvath, E., Tatrai, E., and Ungvary, G. (1989). Acute effects of cadmium on preovulatory serum $\mathrm{FSH}, \mathrm{LH}$, and prolactin levels and on ovulation and ovarian hormone secretion in estrous rats. Reproductive toxicology (Elmsford, N.Y 3, 241-247.

Paksy, K., Varga, B., and Lazar, P. (1997b). Zinc protection against cadmium-induced infertility in female rats. Effect of zinc and cadmium on the progesterone production of cultured granulosa cells. Biometals 10, 27-35.

Paksy, K., Varga, B., Naray, M., Olajos, F., and Folly, G. (1992). Altered ovarian progesterone secretion induced by cadmium fails to interfere with embryo transport in the oviduct of the rat. Reproductive toxicology (Elmsford, N.Y 6, 7783.

Palmer, D. B., Viney, J. L., Ritter, M. A., Hayday, A. C., and Owen, M. J. (1993). Expression of the alpha beta T-cell receptor is necessary for the generation of the thymic medulla. Developmental immunology 3, 175-179. 
Park, J. D., Liu, Y., and Klaassen, C. D. (2001). Protective effect of metallothionein against the toxicity of cadmium and other metals(1). Toxicology. 163, 93-100.

Pastorelli, G., Rousset, F., and Pene, J. (1990) Cord blood B cells are mature in their capacity to switch to IgE-producing cells in response to interlukin-4 in vitro. Clin Exp Immunol 82:114-119.

Patel, S. R., Gordon, J., Mahbub, F., Blackburn, C. C., and Manley, N. R. (2006). Bmp4 and Noggin expression during early thymus and parathyroid organogenesis. Gene Expr Patterns 6, 794-799.

Pathak, N., and Khandelwal, S. (2006). Influence of cadmium on murine thymocytes: potentiation of apoptosis and oxidative stress. Toxicol Lett. 165, 121-132.

Pathak, N., and Khandelwal, S. (2007a). Impact of cadmium in T lymphocyte subsets and cytokine expression: differential regulation by oxidative stress and apoptosis. Biometals.

Pathak, N., and Khandelwal, S. (2007b). Role of oxidative stress and apoptosis in cadmium induced thymic atrophy and splenomegaly in mice. Toxicology Letters.

Penit, C., Lucas, B., and Vasseur, F. (1995). Cell expansion and growth arrest phases during the transition from precursor (CD4-8-) to immature $(C D 4+8+)$ thymocytes in normal and genetically modified mice. J Immunol 154, 5103-5113.

Penit, C., and Vasseur, F. (1989). Cell proliferation and differentiation in the fetal and early postnatal mouse thymus, pp. 3369-3377.

Pepinsky, R. B., Zeng, C., Wen, D., Rayhorn, P., Baker, D. P., Williams, K. P., Bixler, S. A., Ambrose, C. M., Garber, E. A., Miatkowski, K., Taylor, F. R., Wang, E. A., and 
Galdes, A. (1998). Identification of a palmitic acid-modified form of human Sonic hedgehog. The Journal of biological chemistry 273, 14037-14045.

Peters, J. M., Duncan, J. R., Wiley, L. M., and Keen, C. L. (1995). Influence of antioxidants on cadmium toxicity of mouse preimplantation embryos in vitro. Toxicology 99, 11-18.

Petrie, H. T. (2002). Role of thymic organ structure and stromal composition in steadystate postnatal T-cell production. Immunological reviews 189, 8-19.

Petrie, H. T. (2003). Cell migration and the control of post-natal T-cell lymphopoiesis in the thymus. Nature reviews 3, 859-866.

Petrie, H. T., Livak, F., Schatz, D. G., Strasser, A., Crispe, I. N., and Shortman, K. (1993). Multiple rearrangements in T cell receptor alpha chain genes maximize the production of useful thymocytes. The Journal of experimental medicine $\mathbf{1 7 8}$, 615-622.

Petrie, H. T., and Zuniga-Pflucker, J. C. (2007). Zoned out: functional mapping of stromal signaling microenvironments in the thymus. Annual review of immunology 25, 649-679.

Piasek, M., Blanusa, M., Kostial, K., and Laskey, J. W. (2001). Placental cadmium and progesterone concentrations in cigarette smokers. Reproductive toxicology (Elmsford, N.Y 15, 673-681.

Piasek, M., and Laskey, J. W. (1994). Acute cadmium exposure and ovarian steroidogenesis in cycling and pregnant rats. Reproductive toxicology (Elmsford, N.Y 8, 495-507. 
Pillet, S., D'Elia, M., Bernier, J., Bouquegneau, J. M., Fournier, M., and Cyr, D. G. (2006). Immunomodulatory Effects of Estradiol and Cadmium in Adult Female Rats. Toxicological Sciences 92, 423-432.

Pillet, S., Rooney, A. A., Bouquegneau, J.-M., Cyr, D. G., and Fournier, M. (2005). Sexspecific effects of neonatal exposures to low levels of cadmium through maternal milk on development and immune functions of juvenile and adult rats. Toxicology 209, 289-301.

Pongracz, J., Hare, K., Harman, B., Anderson, G., and Jenkinson, E. J. (2003). Thymic epithelial cells provide WNT signals to developing thymocytes. European journal of immunology 33, 1949-1956.

Pongracz, J. E., Parnell, S. M., Jones, T., Anderson, G., and Jenkinson, E. J. (2006). Overexpression of ICAT highlights a role for catenin-mediated canonical Wnt signalling in early T cell development. European journal of immunology 36, 23762383.

Porter, J. A., von Kessler, D. P., Ekker, S. C., Young, K. E., Lee, J. J., Moses, K., and Beachy, P. A. (1995). The product of hedgehog autoproteolytic cleavage active in local and long-range signalling. Nature 374, 363-366.

Potts, C. L. (1965). Cadmium Proteinuria--the Health of Battery Workers Exposed to Cadmium Oxide Dust. The Annals of occupational hygiene 8, 55-61.

Prozialeck, W. C., Lamar, P. C., and Lynch, S. M. (2003). Cadmium alters the localization of $\mathrm{N}$-cadherin, E-cadherin, and [beta]-catenin in the proximal tubule epithelium. Toxicology and Applied Pharmacology 189, 180-195. 
Pulido, M. D., and Parrish, A. R. (2003). Metal-induced apoptosis: mechanisms. Mutation research 533, 227-241.

Quaife, C. J., Cherne, R. L., Newcomb, T. G., Kapur, R. P., and Palmiter, R. D. (1999). Metallothionein overexpression suppresses hepatic hyperplasia induced by hepatitis B surface antigen. Toxicology and applied pharmacology 155, 107-116.

Radtke, F., Wilson, A., Mancini, S. J., and MacDonald, H. R. (2004). Notch regulation of lymphocyte development and function. Nature immunology 5, 247-253.

Radtke, F., Wilson, A., Stark, G., Bauer, M., van Meerwijk, J., MacDonald, H. R., and Aguet, M. (1999). Deficient $T$ cell fate specification in mice with an induced inactivation of Notch1. Immunity 10, 547-558.

Ramirez, D. C., and Gimenez, M. S. (2003). Induction of redox changes, inducible nitric oxide synthase and cyclooxygenase-2 by chronic cadmium exposure in mouse peritoneal macrophages. Toxicol Lett 145, 121-132.

Ramirez, D. C., Martinez, L. D., Marchevsky, E., and Gimenez, M. S. (1999). Biphasic effect of cadmium in non-cytotoxic conditions on the secretion of nitric oxide from peritoneal macrophages. Toxicology 139, 167-177.

Ramirez, D. C., Riera, C. M., and Gimenez, M. S. (2001). Modulation of arachidonic acid turnover in macrophages by cadmium. Toxicol Lett 122, 9-19.

Rehm, S., and Waalkes, M. P. (1988). Cadmium-induced ovarian toxicity in hamsters, mice, and rats. Fundam Appl Toxicol 10, 635-647.

Reilly, M. P., Lawson, J. A., and FitzGerald, G. A. (1998). Eicosanoids and isoeicosanoids: indices of cellular function and oxidant stress. The Journal of nutrition 128, 434S-438S. 
Roberts, C. W., Shutter, J. R., and Korsmeyer, S. J. (1994). Hox11 controls the genesis of the spleen. Nature $368,747-749$.

Ronco, A. M., Arguello, G., Munoz, L., Gras, N., and Llanos, M. (2005). Metals content in placentas from moderate cigarette consumers: correlation with newborn birth weight. Biometals 18, 233-241.

Roose, J., Molenaar, M., Peterson, J., Hurenkamp, J., Brantjes, H., Moerer, P., van de Wetering, M., Destree, O., and Clevers, H. (1998). The Xenopus Wnt effector XTcf-3 interacts with Groucho-related transcriptional repressors. Nature 395, 608-612.

Rossi, S. W., Jenkinson, W. E., Anderson, G., and Jenkinson, E. J. (2006). Clonal analysis reveals a common progenitor for thymic cortical and medullary epithelium. Nature 441, 988-991.

Rowbotham, N. J., Hager-Theodorides, A. L., Cebecauer, M., Shah, D. K., Drakopoulou, E., Dyson, J., Outram, S. V., and Crompton, T. (2007a). Activation of the Hedgehog signaling pathway in T-lineage cells inhibits TCR repertoire selection in the thymus and peripheral T-cell activation, pp. 3757-3766.

Rowbotham, N. J., Hager-Theodorides, A. L., Furmanski, A. L., and Crompton, T. (2007b). A Novel Role for Hedgehog in T-Cell Receptor Signaling: Implications for Development and Immunity. Cell Cycle 6.

Ruiz i Altaba, A. (1999). Gli proteins and Hedgehog signaling: development and cancer. Trends Genet 15, 418-425. 
Saaranen, M., Kantola, M., Saarikoski, S., and Vanha-Perttula, T. (1989). Human seminal plasma cadmium: comparison with fertility and smoking habits. Andrologia 21, 140-145.

Sacedon, R., Varas, A., Hernandez-Lopez, C., Gutierrez-deFrias, C., Crompton, T., Zapata, A. G., and Vicente, A. (2003). Expression of Hedgehog Proteins in the Human Thymus. Journal of Histochemistry and Cytochemistry 51, 1557-1566.

Sahmoun, A. E., Case, L. D., Jackson, S. A., and Schwartz, G. G. (2005). Cadmium and prostate cancer: a critical epidemiologic analysis. Cancer investigation 23, 256-263.

Saksena, S. K., and Salmonsen, R. (1983). Effects of cadmium chloride on ovulation and on induction of sterility in the female golden hamster. Biol Reprod 29, 249256.

Schilham, M. W., Wilson, A., Moerer, P., Benaissa-Trouw, B. J., Cumano, A., and Clevers, H. C. (1998). Critical involvement of Tcf-1 in expansion of thymocytes. J Immunol 161, 3984-3991.

Schmid, B. P., Hall, J. L., Goulding, E., Fabro, S., and Dixon, R. (1983). In vitro exposure of male and female mice gametes to cadmium chloride during the fertilization process, and its effects on pregnancy outcome. Toxicol Appl Pharmacol 69, 326-332.

Schmitt, T. M., Ciofani, M., Petrie, H. T., and Zuniga-Pflucker, J. C. (2004). Maintenance of $\mathrm{T}$ cell specification and differentiation requires recurrent notch receptor-ligand interactions. The Journal of experimental medicine 200, 469-479. 
Schmitt, T. M., and Zuniga-Pflucker, J. C. (2005). Thymus-derived signals regulate early T-cell development. Critical reviews in immunology 25, 141-159.

Schoeters, G., Den, H. E., Zuurbier, M., Naginiene, R., van den, H. P., Stilianakis, N., Ronchetti, R., and Koppe, J. G. (2006). Cadmium and children: exposure and health effects. Acta Paediatr.Suppl. 95, 50-54.

Scollay, R., and Godfrey, D. I. (1995). Thymic emigration: conveyor belts or lucky dips? Immunology today 16, 268-273; discussion 273-264.

Scott, W. J., Jr., Schreiner, C. M., Goetz, J. A., Robbins, D., and Bell, S. M. (2005). Cadmium-induced postaxial forelimb ectrodactyly: association with altered sonic hedgehog signaling. Reproductive toxicology (Elmsford, N.Y 19, 479-485.

Senoo, M., Pinto, F., Crum, C. P., and McKeon, F. (2007). p63 Is essential for the proliferative potential of stem cells in stratified epithelia. Cell 129, 523-536.

Shah, D. K., Hager-Theodorides, A. L., Outram, S. V., Ross, S. E., Varas, A., and Crompton, T. (2004). Reduced thymocyte development in sonic hedgehog knockout embryos. J Immunol 172, 2296-2306.

Shen, X., Lee, K., and Konig, R. (2001). Effects of heavy metal ions on resting and antigen-activated CD4(+) T cells. Toxicology 169, 67-80.

Shores, E. W., Van Ewijk, W., and Singer, A. (1991). Disorganization and restoration of thymic medullary epithelial cells in T cell receptor-negative scid mice: evidence that receptor-bearing lymphocytes influence maturation of the thymic microenvironment. European journal of immunology 21, 1657-1661. 
Shortman, K., and Vremec, D. (1991). Different subpopulations of developing thymocytes are associated with adherent (macrophage) or nonadherent (dendritic) thymic rosettes. Developmental immunology 1, 225-235.

Shortman, K., and Wu, L. (1996). Early T lymphocyte progenitors. Annual review of immunology 14, 29-47.

Silva, E., Lopez-Espinosa, M. J., Molina-Molina, J. M., Fernandez, M., Olea, N., and Kortenkamp, A. (2006). Lack of activity of cadmium in in vitro estrogenicity assays. Toxicol Appl Pharmacol 216, 20-28.

Simonet, M., Berche, P., Fauchere, J. L., and Veron, M. (1984). Impaired resistance to Listeria monocytogenes in mice chronically exposed to cadmium. Immunology 53, 155-163.

Simonyte, S., Cerkasin, G., Planciuniene, R., Naginiene, R., Ryselis, S., and Ivanov, L. (2003). Influence of cadmium and zinc on the mice resistance to Listeria monocytogenes infection. Medicina (Kaunas, Lithuania) 39, 767-772.

Staal, F. J., and Clevers, H. C. (2003). Wnt signaling in the thymus. Current opinion in immunology 15, 204-208.

Staal, F. J., Meeldijk, J., Moerer, P., Jay, P., van de Weerdt, B. C., Vainio, S., Nolan, G. P., and Clevers, H. (2001). Wnt signaling is required for thymocyte development and activates Tcf-1 mediated transcription. European journal of immunology $\mathbf{3 1}$, 285-293.

Staal, F. J., Weerkamp, F., Baert, M. R., van den Burg, C. M., van Noort, M., de Haas, E. F., and van Dongen, J. J. (2004). Wnt target genes identified by DNA 
microarrays in immature CD34+ thymocytes regulate proliferation and cell adhesion. J Immunol 172, 1099-1108.

Stadeli, R., Hoffmans, R., and Basler, K. (2006). Transcription under the control of nuclear Arm/beta-catenin. Curr Biol 16, R378-385.

Stamataki, D., Ulloa, F., Tsoni, S. V., Mynett, A., and Briscoe, J. (2005). A gradient of Gli activity mediates graded Sonic Hedgehog signaling in the neural tube. Genes \& development 19, 626-641.

Starr, T. K., Jameson, S. C., and Hogquist, K. A. (2003). Positive and negative selection of T cells. Annual review of immunology 21, 139-176.

Stohs, S. J., and Bagchi, D. (1995). Oxidative mechanisms in the toxicity of metal ions. Free radical biology \& medicine 18, 321-336.

Stohs, S. J., Bagchi, D., Hassoun, E., and Bagchi, M. (2001). Oxidative mechanisms in the toxicity of chromium and cadmium ions. J Environ Pathol Toxicol Oncol 20, 77-88.

Stoica, A., Katzenellenbogen, B. S., and Martin, M. B. (2000). Activation of Estrogen Receptor-\{alpha\} by the Heavy Metal Cadmium. Molecular endocrinology (Baltimore, Md 14, 545-553.

Stone, D. M. (1996). The tumour-suppressor gene patched encodes a candidate receptor for Sonic hedgehog. Nature 384, 129-134.

Storeng, R., and Jonsen, J. (1980). Effect of nickel chloride and cadmium acetate on the development of preimplantation mouse embryos in vitro. Toxicology 17, 183187. 
Su, D. M., Navarre, S., Oh, W. J., Condie, B. G., and Manley, N. R. (2003). A domain of Foxn1 required for crosstalk-dependent thymic epithelial cell differentiation. Nature immunology 4, 1128-1135.

Sugiyama, M. (1994). Role of cellular antioxidants in metal-induced damage. Cell biology and toxicology 10, 1-22.

Sunderman, F. W., Jr., Plowman, M. C., and Hopfer, S. M. (1992). Teratogenicity of cadmium chloride in the South African frog, Xenopus laevis. IARC Sci Publ., 249256.

Suniara, R. K., Jenkinson, E. J., and Owen, J. J. (1999). Studies on the phenotype of migrant thymic stem cells. European journal of immunology 29, 75-80.

Surh, C. D., and Sprent, J. (1994). T-cell apoptosis detected in situ during positive and negative selection in the thymus. Nature $372,100-103$.

Swat, W., von Boehmer, H., and Kisielow, P. (1994). Small CD4+8+TCRlow thymocytes contain precursors of mature T cells. European journal of immunology 24, 10101012.

Swierkosz, T. A., Mitchell, J. A., Warner, T. D., Botting, R. M., and Vane, J. R. (1995). Co-induction of nitric oxide synthase and cyclo-oxygenase: interactions between nitric oxide and prostanoids. British journal of pharmacology 114, 1335-1342.

Tago, K., Nakamura, T., Nishita, M., Hyodo, J., Nagai, S., Murata, Y., Adachi, S., Ohwada, S., Morishita, Y., Shibuya, H., and Akiyama, T. (2000). Inhibition of Wnt signaling by ICAT, a novel beta-catenin-interacting protein. Genes \& development 14, 1741-1749. 
Taipale, J., Cooper, M. K., Maiti, T., and Beachy, P. A. (2002). Patched acts catalytically to suppress the activity of Smoothened. Nature 418, 892-896.

Takemaru, K., Yamaguchi, S., Lee, Y. S., Zhang, Y., Carthew, R. W., and Moon, R. T. (2003). Chibby, a nuclear beta-catenin-associated antagonist of the Wnt/Wingless pathway. Nature 422, 905-909.

Takenaka, S., Oldiges, H., Konig, H., Hochrainer, D., and Oberdorster, G. (1983). Carcinogenicity of cadmium chloride aerosols in W rats. Journal of the National Cancer Institute 70, 367-373.

Tam, P. P., and Liu, W. K. (1985). Gonadal development and fertility of mice treated prenatally with cadmium during the early organogenesis stages. Teratology. $\mathbf{3 2}$, 453-462.

Tenzen, T., Allen, B. L., Cole, F., Kang, J. S., Krauss, R. S., and McMahon, A. P. (2006). The cell surface membrane proteins cdo and boc are components and targets of the hedgehog signaling pathway and feedback network in mice. Dev.Cell. 10, 647-656.

Thevenod, F., Friedmann, J. M., Katsen, A. D., and Hauser, I. A. (2000). Up-regulation of multidrug resistance P-glycoprotein via nuclear factor-kappaB activation protects kidney proximal tubule cells from cadmium- and reactive oxygen species-induced apoptosis. The Journal of biological chemistry 275, 1887-1896.

Thevenod, F., Wolff, N. A., Bork, U., Lee, W. K., and Abouhamed, M. (2007). Cadmium induces nuclear translocation of beta-catenin and increases expression of c-myc and Abcb1a in kidney proximal tubule cells. Biometals 20, 807-820. 
Thompson, J., Wong, L., Lau, P. S., and Bannigan, J. (2008). Adherens junction breakdown in the periderm following cadmium administration in the chick embryo: distribution of cadherins and associated molecules. Reproductive toxicology (Elmsford, N.Y 25, 39-46.

Torreblanca, A., Del Ramo, J., and Sarkar, B. (1992). Cadmium effect on zinc metabolism in human trophoblast cells: involvement of cadmium-induced metallothionein. Toxicology 72, 167-174.

Torroja, C., Gorfinkiel, N., and Guerrero, I. (2005). Mechanisms of Hedgehog gradient formation and interpretation. Journal of neurobiology 64, 334-356.

Townsley, F. M., Thompson, B., and Bienz, M. (2004). Pygopus residues required for its binding to Legless are critical for transcription and development. The Journal of biological chemistry 279, 5177-5183.

Tribioli, C., and Lufkin, T. (1999). The murine Bapx1 homeobox gene plays a critical role in embryonic development of the axial skeleton and spleen. Development (Cambridge, England) 126, 5699-5711.

Tsai, P. T., Lee, R. A., and Wu, H. (2003). BMP4 acts upstream of FGF in modulating thymic stroma and regulating thymopoiesis. Blood 102, 3947-3953.

Ueno, T., Saito, F., Gray, D. H., Kuse, S., Hieshima, K., Nakano, H., Kakiuchi, T., Lipp, M., Boyd, R. L., and Takahama, Y. (2004). CCR7 signals are essential for cortexmedulla migration of developing thymocytes. The Journal of experimental medicine 200, 493-505. 
Valko, M., Rhodes, C. J., Moncol, J., Izakovic, M., and Mazur, M. (2006). Free radicals, metals and antioxidants in oxidative stress-induced cancer. Chemico-biological interactions 160, 1-40.

van den Heuvel, M., and Ingham, P. W. (1996). smoothened encodes a receptor-like serpentine protein required for hedgehog signalling. Nature $\mathbf{3 8 2}, 547-551$.

Verbeek, S., Izon, D., Hofhuis, F., Robanus-Maandag, E., te Riele, H., van de Wetering, M., Oosterwegel, M., Wilson, A., MacDonald, H. R., and Clevers, H. (1995). An HMG-box-containing T-cell factor required for thymocyte differentiation. Nature 374, 70-74.

Virts, E. L., Phillips, J. A., and Thoman, M. L. (2006). A novel approach to thymic rejuvenation in the aged. Rejuvenation.Res. 9, 134-142.

Visser, A. J., and Deklerk, J. N. (1978). The effect of dietary cadmium on prostate growth. Transactions of the American Association of Genito-Urinary Surgeons 70, 66-68.

von Boehmer, H., Aifantis, I., Feinberg, J., Lechner, O., Saint-Ruf, C., Walter, U., Buer, J., and Azogui, O. (1999). Pleiotropic changes controlled by the pre-T-cell receptor. Current opinion in immunology 11, 135-142.

von Zglinicki, T., Edwall, C., Ostlund, E., Lind, B., Nordberg, M., Ringertz, N. R., and Wroblewski, J. (1992). Very low cadmium concentrations stimulate DNA synthesis and cell growth. Journal of cell science 103 ( Pt 4), 1073-1081.

Vrsanska, S., Nagyova, E., Mlynarcikova, A., Fickova, M., and Kolena, J. (2003). Components of cigarette smoke inhibit expansion of oocyte-cumulus complexes 
from porcine follicles. Physiological research / Academia Scientiarum Bohemoslovaca 52, 383-387.

Waalkes, M. P. (2000). Cadmium carcinogenesis in review. Journal of Inorganic Biochemistry 79, 241-244.

Waalkes, M. P. (2003). Cadmium carcinogenesis. Mutation Research/Fundamental and Molecular Mechanisms of Mutagenesis 533, 107-120.

Waalkes, M. P., Anver, M., and Diwan, B. A. (1999a). Carcinogenic effects of cadmium in the noble $(\mathrm{NBL} / \mathrm{Cr})$ rat: induction of pituitary, testicular, and injection site tumors and intraepithelial proliferative lesions of the dorsolateral prostate. Toxicol Sci 52, 154-161.

Waalkes, M. P., Anver, M. R., and Diwan, B. A. (1999b). Chronic toxic and carcinogenic effects of oral cadmium in the Noble (NBL/Cr) rat: induction of neoplastic and proliferative lesions of the adrenal, kidney, prostate, and testes. $J$ Toxicol Environ Health A 58, 199-214.

Waalkes, M. P., Coogan, T. P., and Barter, R. A. (1992a). Toxicological principles of metal carcinogenesis with special emphasis on cadmium. Critical reviews in toxicology 22, 175-201.

Waalkes, M. P., and Rehm, S. (1994). Chronic toxic and carcinogenic effects of cadmium chloride in male $\mathrm{DBA} / 2 \mathrm{NCr}$ and $\mathrm{NFS} / \mathrm{NCr}$ mice: strain-dependent association with tumors of the hematopoietic system, injection site, liver, and lung. Fundam Appl Toxicol 23, 21-31. 
Waalkes, M. P., Rehm, S., Sass, B., and Ward, J. M. (1992b). Induction of tumours of the haematopoietic system by cadmium in rats. IARC scientific publications, 401404.

Waisberg, M., Joseph, P., Hale, B., and Beyersmann, D. (2003). Molecular and cellular mechanisms of cadmium carcinogenesis. Toxicology 192, 95-117.

Wallis, V. J., Leuchars, E., Chwalinski, S., and Davies, A. J. (1975). On the sparse seeding of bone marrow and thymus in radiation chimaeras. Transplantation 19, $2-11$.

Wang, B., Fallon, J. F., and Beachy, P. A. (2000). Hedgehog-regulated processing of Gli3 produces an anterior/posterior repressor gradient in the developing vertebrate limb. Cell 100, 423-434.

Watanabe, M., Henmi, K., Ogawa, K., and Suzuki, T. (2003). Cadmium-dependent generation of reactive oxygen species and mitochondrial DNA breaks in photosynthetic and non-photosynthetic strains of Euglena gracilis. Comp Biochem Physiol C Toxicol Pharmacol 134, 227-234.

Webber, M. M., Perez-Ripoll, E. A., and James, G. T. (1985). Inhibitory effects of selenium on the growth of DU-145 human prostate carcinoma cells in vitro. Biochem Biophys Res Commun 130, 603-609.

Webster, W. S., and Messerle, K. (1980). Changes in the mouse neuroepithelium associated with cadmium-induced neural tube defects. Teratology $\mathbf{2 1}, 79-88$.

Weerkamp, F., Baert, M. R. M., Naber, B. A. E., Koster, E. E. L., de Haas, E. F. E., Atkuri, K. R., van Dongen, J. J. M., Herzenberg, L. A., and Staal, F. J. T. (2006). 
Wnt signaling in the thymus is regulated by differential expression of intracellular signaling molecules, pp. 3322-3326.

Wegmann, T., Lin, H., Guilbert, L., Mosmann, T. (1993) Bidirectional cytokine interactions in the maternal-fetal relationship: is successful pregnancy aTh2 phenomenon? Immunol Today 14, 353-356.

West, D. W., Slattery, M. L., Robison, L. M., French, T. K., and Mahoney, A. W. (1991). Adult dietary intake and prostate cancer risk in Utah: a case-control study with special emphasis on aggressive tumors. Cancer Causes Control 2, 85-94.

Wier, P. J., Miller, R. K., Maulik, D., and di Sant'Agnese, P. A. (1990). Toxicity of cadmium in the perfused human placenta. Toxicology and Applied Pharmacology 105, 156-171.

Willert, K., Brown, J. D., Danenberg, E., Duncan, A. W., Weissman, I. L., Reya, T., Yates, J. R., 3rd, and Nusse, R. (2003). Wnt proteins are lipid-modified and can act as stem cell growth factors. Nature $\mathbf{4 2 3}, 448-452$.

Wlodarczyk, B., Biernacki, B., Minta, M., and Zmudzki, J. (2001). Postimplantation whole embryo culture assay for hamsters: an alternative to rat and mouse. TheScientificWorldJournal 1, 227-234.

Wu, L., Li, C. L., and Shortman, K. (1996). Thymic dendritic cell precursors: relationship to the $\mathrm{T}$ lymphocyte lineage and phenotype of the dendritic cell progeny. The Journal of experimental medicine 184, 903-911.

Wynshaw-Boris, A. (2006). Inborn errors of development: disruption of pathways critical for normal development. Pediatric clinics of North America 53, 855-871, viii. 
Xu, Y., Banerjee, D., Huelsken, J., Birchmeier, W., and Sen, J. M. (2003). Deletion of beta-catenin impairs T cell development. Nature immunology 4, 1177-1182.

Yabuhara, A., Kawai, H., Komiyama, A. (1990) Development of natural killer cell cytotoxicity during childhood: marked increases in number of natural killer cells with adequate cytotoxic abilities during infancy to early childhood. Pediatr Res 28, 316-322.

Yamasaki, S., Ishikawa, E., Sakuma, M., Ogata, K., Sakata-Sogawa, K., Hiroshima, M., Wiest, D. L., Tokunaga, M., and Saito, T. (2006). Mechanistic basis of pre-T cell receptor-mediated autonomous signaling critical for thymocyte development. Nature immunology 7, 67-75.

Yang, J. M., Arnush, M., Chen, Q. Y., Wu, X. D., Pang, B., and Jiang, X. Z. (2003). Cadmium-induced damage to primary cultures of rat Leydig cells. Reproductive toxicology (Elmsford, N.Y 17, 553-560.

Yu, H. S., and Chan, S. T. (1988). Zinc amelioration of cadmium toxicity on preimplantation mouse zygotes in vitro. Teratology 37, 13-19.

Yu, Q., and Sen, J. M. (2007). beta-Catenin Regulates Positive Selection of Thymocytes but Not Lineage Commitment. J Immunol 178, 5028-5034.

Yu, Q., Xu, M., and Sen, J. M. (2007). Beta-catenin expression enhances IL-7 receptor signaling in thymocytes during positive selection. J Immunol 179, 126-131.

Yucesoy, B., Turhan, A., Ure, M., Imir, T., and Karakaya, A. (1997). Effects of occupational lead and cadmium exposure on some immunoregulatory cytokine levels in man. Toxicology 123, 143-147. 
Yurkow, E. J., and Makhijani, P. R. (1998). Flow cytometric determination of metallothionein levels in human peripheral blood lymphocytes: utility in environmental exposure assessment. Journal of toxicology and environmental health 54, 445-457.

Zalups, R. K., and Ahmad, S. (2003). Molecular handling of cadmium in transporting epithelia. Toxicol Appl Pharmacol 186, 163-188.

Zeng, X., Goetz, J. A., Suber, L. M., Scott, W. J., Jr., Schreiner, C. M., and Robbins, D. J. (2001). A freely diffusible form of Sonic hedgehog mediates long-range signalling. Nature 411, 716-720.

Zeng, X., Huang, H., Tamai, K., Zhang, X., Harada, Y., Yokota, C., Almeida, K., Wang, J., Doble, B., Woodgett, J., Wynshaw-Boris, A., Hsieh, J. C., and He, X. (2008). Initiation of Wnt signaling: control of Wnt coreceptor Lrp6 phosphorylation/activation via frizzled, dishevelled and axin functions. Development (Cambridge, England) 135, 367-375.

Zeng, X., Tamai, K., Doble, B., Li, S., Huang, H., Habas, R., Okamura, H., Woodgett, J., and He, X. (2005). A dual-kinase mechanism for Wnt co-receptor phosphorylation and activation. Nature 438, 873-877.

Zhai, L., Chaturvedi, D., and Cumberledge, S. (2004). Drosophila wnt-1 undergoes a hydrophobic modification and is targeted to lipid rafts, a process that requires porcupine. The Journal of biological chemistry 279, 33220-33227.

Zhou, T., Jia, X., Chapin, R. E., Maronpot, R. R., Harris, M. W., Liu, J., Waalkes, M. P., and Eddy, E. M. (2004). Cadmium at a non-toxic dose alters gene expression in mouse testes. Toxicol Lett 154, 191-200. 
Zou, D., Silvius, D., Davenport, J., Grifone, R., Maire, P., and Xu, P. X. (2006). Patterning of the third pharyngeal pouch into thymus/parathyroid by Six and Eya1. Developmental biology 293, 499-512. 
CHAPTER 2: Prenatal cadmium exposure dysregulates sonic hedgehog and Wnt/ $\beta$-catenin signaling in the thymus resulting in altered thymocyte development 
Prenatal cadmium exposure dysregulates sonic hedgehog and Wnt/ $\beta$-catenin signaling in the thymus resulting in altered thymocyte development ${ }^{1}$

Miranda L. Hanson*, Kathleen M. Brundage ${ }^{*}$, Rosana Schafer ${ }^{*}$, Janet Tou ${ }^{\dagger}$, and John B. Barnett $^{*}$

*Department of Microbiology, Immunology and Cell Biology, West Virginia University School of Medicine, ${ }^{\dagger}$ Department of Animal and Nutritional Sciences, Davis College of Agriculture, Forestry and Consumer Sciences, West Virginia University, Morgantown, WV 26506

Running title: Prenatal Cd alters signaling necessary for thymocyte development

${ }^{1}$ This work was supported by National Institutes of Health Grants [ES015539 to J.B.B and RR016440 and RR020866 for flow cytometry].

Correspondence to:

John B. Barnett, Ph.D.

Department of Microbiology, Immunology and Cell Biology

PO Box 9177

West Virginia University

Morgantown, WV. 26506-9177

(T). 304-293-4029; (F) 304-293-7823

jbarnett@hsc.wvu.edu 


\section{ABSTRACT}

Cadmium (Cd) is both an environmental pollutant as well as a component of cigarette smoke. Although evidence demonstrates that adult exposure to $\mathrm{Cd}$ causes changes in the immune system, there are limited reports in the literature of immunomodulatory effects of prenatal exposure to $\mathrm{Cd}$. The sonic hedgehog (Shh) and Wnt/ $\beta$-catenin pathways are required for thymocyte maturation. Several studies have demonstrated that $\mathrm{Cd}$ exposure affects these pathways in different organ systems. This study was designed to investigate the effect of prenatal Cd exposure on thymocyte development, and to determine if these effects were linked to dysregulation of Shh and $\mathrm{Wnt} / \beta$-catenin pathways. Pregnant C57BI/6 mice were exposed to an environmentally relevant dose (10 ppm) of Cd throughout pregnancy and effects on the thymus were assessed on the day of birth. Thymocyte phenotype was determined by flow cytometry. A Gli:luciferase reporter cell line was used to measure Shh signaling. Transcription of target genes and translation of key components of both signaling pathways was assessed using real-time RT-PCR and western blot, respectively. Prenatal Cd exposure increased the number of $\mathrm{CD}^{+}$cells and a subpopulation of double-negative cells (DN; CD4CD8-), DN4 (CD44 $\left.\mathrm{CD}^{\circ}\right)$ ). Shh and $\mathrm{Wnt} / \beta$-catenin signaling were both decreased in the thymus; however, this was not due to altered Shh and Wnt protein levels. Target genes of Shh (Patched1 and Gli1) and Wnt/ $\beta$-catenin (c-fos, c-jun, and c-myc) were affected differentially among thymocyte subpopulations. These findings suggest that prenatal exposure to $\mathrm{Cd}$ dysregulates two signaling pathways in the thymus, resulting in altered thymocyte development. 


\section{INTRODUCTION}

Cadmium (Cd), a heavy metal, is an environmental pollutant due to its widespread and continual use. It currently ranks seventh on the Agency of Toxic Substances and Disease Registry/Environmental Protection Agency (ATSDR/EPA) list of Hazardous Substances (ATSDR, 2007). Humans normally absorb Cd into the body either by ingestion or inhalation (Lauwerys et al., 1986). The daily intake is estimated to be approximately $10-50 \mu \mathrm{g}$, but can reach levels of $200-1000 \mu \mathrm{g}$ in highly contaminated areas (Nordberg, 2006). Cd concentrations in food normally range from 10-20 $\mu \mathrm{g}$, while a cigarette contains 1-2 $\mu \mathrm{g}$. Cd levels in soils, particularly areas in which phosphate fertilizers have been applied, can range from 10 to $200 \mu \mathrm{g} / \mathrm{g}$ (Cook, 1995). Cd has a half-life of 15-20 years in humans, which contributes to its toxicity (Jin et al., 1998). Cd exposure during gestation leads to a variety of fetal malformations in rodents, such as postaxial forelimb ectrodactyly (Scott et al., 2005), delayed effects on renal function (Jacquillet et al., 2007), and sensorimotor development (Minetti and Reale, 2006). Despite the known teratogenic effects of $\mathrm{Cd}$, only one report concerning the effect of $\mathrm{Cd}$ exposure during gestation on the immune system was found (Soukupova et al., 1991). In that study, pregnant ICR mice were administered Cd on day 16 of gestation, and the immune responses of their offspring were tested at 4 and 8 weeks of age. Proliferative responses of spleen cells to mitogens and activity of peritoneal macrophages were increased, while delayed type hypersensitivity to sheep red blood cells after immunization was decreased, in Cd-exposed offspring. 
The thymus is a target organ of Cd-induced toxicity. Cd-treatment of adult rats results in damage to the thymus as well as changes in the proliferation rate of thymocytes (Morselt et al., 1988). T-cell development in the thymus is essential for the establishment and maintenance of the adaptive immune system. Thymocytes mature through a series of stages defined by expression of cell surface markers CD4 and CD8. The most immature thymocytes are $\mathrm{CD}^{-} \mathrm{CD} 8^{-}$double-negative (DN). This population gives rise to $C D 4^{+} \mathrm{CD} 8^{+}$double-positive (DP) cells, which then give rise to mature $\mathrm{CD}^{+} \mathrm{CD} 8^{-}$single-positive (SP) and $\mathrm{CD} 4^{-} \mathrm{CD} 8^{+} \mathrm{SP}$ cells. The DN population is then further subdivided in mice based on the expression of surface markers CD25 and CD44: $C D 44^{+}{ }^{+} D 25^{-}$(DN1) cells differentiate into $C D 44^{+} C D 25^{+}$(DN2) cells, which then develop into $\mathrm{CD}^{-} 4^{-} \mathrm{CD} 25^{+}$(DN3) cells, which differentiate into $\mathrm{CD}^{-} \mathrm{CD}^{-} 5^{-}$(DN4) cells. Several in vivo experiments in adult rodents have demonstrated that Cd causes decreased thymus weight as well as thymic atrophy (Borgman et al., 1986; Mackova et al., 1996; Liu et al., 1999). In adult mice, Dong et al. observed a decrease in DP cells (2001). Pathak and Khandelwal supported these findings and demonstrated that $\mathrm{Cd}$ exposure increased the number of DN cells (Pathak and Khandelwal, 2007).

The Hedgehog $(\mathrm{Hh})$ and Wnt family proteins act as morphogens during thymocyte development. The $\mathrm{Hh}$ family of secreted intercellular signaling molecules is an important regulator in patterning and organogenesis during animal development. There are three mammalian Hh proteins: sonic hedgehog (Shh), Indian hedgehog (Ihh), and desert hedgehog (Dhh). Hh proteins share a common signaling pathway. They bind to their surface receptor Patched (Ptc), in order to signal to neighboring cells (Marigo et al., 1996; Stone, 1996). Ptc releases its suppression of the cell surface molecule 
Smoothened (Smo), enabling the Hh signal to be transmitted into the target cell (van den Heuvel and Ingham, 1996). This transduction is regulated by complex interactions and modifications of many cytoplasmic proteins ultimately resulting in the activation of members of the Gli family of zinc finger transcription factors (Gli 1-3) (Ingham and McMahon, 2001). When Hh protein is absent, Ptc inhibits the ability of Smo to signal (Chen and Struhl, 1998; Taipale et al., 2002). Shh signaling, in particular, is critical in the development of thymocytes and T-cell activation (Shah et al., 2004). Shh proteins act as regulators at several stages of T-cell development in the thymus.

In addition to Hh proteins, the Wnt family of glycoproteins is involved in regulating thymocyte maturation (Staal et al., 2001). Wnt proteins are secreted morphogens that are involved in a variety of cell activities in development. Wht signals are transduced through at least three different signaling pathways; however, the canonical $\beta$-catenin/Tcell factor-lymphoid enhancer factor (TCF-LEF) primarily functions during thymocyte development. The canonical pathway is stimulated by Wnt proteins that bind to cell surface Frizzled (Fz) receptors (Bhanot et al., 1996). Signaling through Fz receptors following Wnt binding results in the stabilization of $\beta$-catenin (Behrens et al., 1996). $\beta$ catenin is a multifunctional protein that can enter the nucleus and function as a transcription factor (Novak and Dedhar, 1999). When Wnt signaling is absent, free $\beta$ -

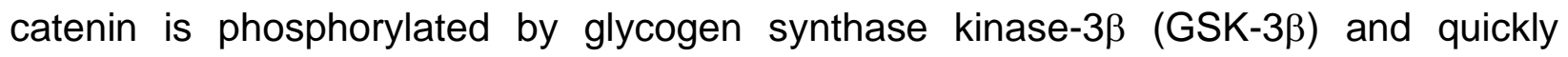
targeted for proteosomal degradation (Ikeda et al., 1998; Amit et al., 2002; Gao et al., 2002). Inhibition of the Wnt pathway results in reduced DN proliferation and differentiation, and decreased DP survival (Verbeek et al., 1995; Okamura et al., 1998; Schilham et al., 1998). 
$\mathrm{Cd}$ has been found to downregulate Shh signaling in mouse embryonic limb buds (Scott et al., 2005) and zebrafish embryos (Yu et al., 2006), as well as to dysregulate the Wnt pathway in chick embryonic periderm (Thompson et al., 2008) and proximal tubule cells (Prozialeck et al., 2003; Thevenod et al., 2007). The purpose of this study was to investigate the effect of prenatal $\mathrm{Cd}$ exposure on thymocyte development, and to determine if these effects were linked to dysregulation of the Shh and $\mathrm{Wnt} / \beta$-catenin pathways. 


\section{MATERIALS AND METHODS}

\section{Breeding and Dosing Methodology}

C57BI/6 mice at 8-10 weeks of age were obtained from Hilltop Lab Animals, Inc. (Scottsdale, PA). The C57BI/6 strain of mouse was used for these experiments due to its reported teratogenic susceptibility to Cd treatment (Hovland et al., 1999). Mice were allowed to acclimate on site for at least one week. Two females were placed in a cage with one male for 72 hours to maximize pregnancy rate. Females were inspected for a vaginal plug and if present, this day was declared as gestational day 0 . For each experiment, ten dams were used as controls, having free access to deionized distilled water $\left(\mathrm{ddH}_{2} \mathrm{O}\right)$, while ten additional dams had free access to $10 \mathrm{ppm}$ of $\mathrm{Cd}$ as $\mathrm{CdCl}_{2}$ (Sigma-Aldrich; St. Louis, MO) dissolved in $\mathrm{dd}_{2} \mathrm{O}$. The dose of $10 \mathrm{ppm}$ was chosen because it is the greatest concentration that will elicit immunomodulatory effects in adult rodents without causing systemic effects (Lafuente et al., 2003). Cd administration was stopped at birth. At post-natal day 0 (PND0), which was $<12 \mathrm{~h}$ following birth, 3 offspring from each litter were euthanized and thymi were removed.

\section{Cd concentration in kidneys}

Cd levels in the kidneys of dams, and the kidneys and livers of offspring were measured following parturition, due to Cd's known accumulation and retention in these organs (Webb, 1972). The purpose of determining how much Cd was retained in the kidneys of the dams was to verify that the dams were consuming approximately equal amounts of water, and thus, Cd dosing was consistent between dams. To measure Cd content, kidney and liver samples were dissolved in $2 \mathrm{ml}$ of $70 \%$ nitric acid. The 
acidified samples were neutralized in $5 \mathrm{ml}$ of $\mathrm{ddH}_{2} \mathrm{O}$ and filtered through Whatman no.1

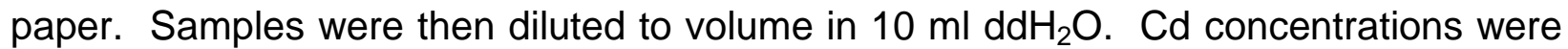
measured using an inductively coupled plasma optical emission spectrometry (ICPOES) (model P400 Perkin Elmer, Shelton, CT). The minimum level of detection of the ICP-OES for $\mathrm{Cd}$ is $2.5 \mathrm{ppb}$.

Sex determination

The sex of newborn mice was determined by amplifying the Y-chromosomespecific SRY gene by PCR. The end piece of each tail $(\approx 5 \mathrm{~mm})$ was trimmed and lysed

in DirectPCR Lysis Reagent (Viagen Biotech, Inc., Los Angeles, CA) containing freshly prepared 0.2-0.4 mg/ml Proteinase K (Sigma-Aldrich, St. Louis, MO). After incubation at $55^{\circ} \mathrm{C}$ for $5-6 \mathrm{~h}$ with vigorous shaking, crude lysates were incubated at $85^{\circ} \mathrm{C}$ for 45 min by floating the tubes on a water bath. One $\mu$ of DNA was used in a $25 \mu \mathrm{lPCR}$ reaction also containing $0.5 \mu \mathrm{M}$ SRY primers (F: 5'- GAGAGCATGGAGGGCCAT-3'; R: 5'-CCACTCCTCTGTGACACT-3'), $0.5 \mu \mathrm{M} \quad \beta$-actin primers (F: 5'TGTGATGGTGGGAATGGGTCAG-3'; R: 5'-TTTGATGTCACGATTTCC-3'), $15 \mu \mathrm{l}$ of 5 PRIME HotMasterMix (Gaithersburg, MD) and molecular biology grade water. $\beta$-actin, a housekeeping gene, was used as a positive control for the PCR reaction. The PCR reaction was performed with a GenAmp PCR System 9700 thermal cycler (Perkin-Elmer Applied Biosystems, Foster City, CA). PCR program was 1.5 min at $94^{\circ} \mathrm{C}$, then 30 cycles of $30 \mathrm{~s}$ at $94^{\circ} \mathrm{C}, 30 \mathrm{~s}$ at $60^{\circ} \mathrm{C}$, and $1 \mathrm{~min}$ at $72^{\circ} \mathrm{C}$, then $5 \mathrm{~min}$ at $72^{\circ} \mathrm{C}$. Ten $\mu \mathrm{l}$ of the PCR product underwent electrophoresis on a $1 \%$ agarose gel and was visualized under UV illumination using ethidium bromide staining $(5 \mu \mathrm{g} / \mathrm{ml})$. 
Tissue Isolation and Cell Preparation

Thymi were harvested from euthanized mice and single cell suspensions prepared. The organs from each mouse were kept separate. Red blood cells were lysed using an ammonium chloride lysis buffer. Viable cells were enumerated using trypan blue and a hemacytometer.

Whole thymic lysates and cytoplasmic/nuclear extraction

Thymic lysates used in the Shh-Light 2 cell assay and western blots were prepared by homogenization and sonication of whole thymi in $200 \mu \mathrm{l}$ serum-free Dulbecco's Modified Eagle's Medium (DMEM) (ATCC, Manassas, VA) supplemented with $2 \mu \mathrm{l}$ Protease Inhibitor Cocktail (Sigma-Aldrich). Protein levels were quantitated using the BCA Protein Assay Kit (Pierce, Rockford, IL). Cytoplasmic/nuclear extracts of thymocytes were prepared from single-cell suspensions. Cells were harvested and washed in 1x PBS. The pellet was resuspended in $500 \mu$ of cytoplasm extraction buffer (10mM HEPES, $40 \mathrm{mM} \mathrm{KCl}, 2 \mathrm{mM} \mathrm{MgCl} 2,10 \%$ glycerol, $1 \mathrm{mM} \mathrm{NaPPi}, 1 \mu \mathrm{g} / \mathrm{ml}$ pepstatin, $1 \mu \mathrm{g} / \mathrm{ml}$ aprotinin, $1 \mu \mathrm{g} / \mathrm{ml}$ leupeptin, $1 \mathrm{mM} \mathrm{NaVO}{ }_{4}, 1 \mathrm{mM} \mathrm{NaF}, 1 \mathrm{mM}$ PMSF, $\mathrm{ddH} 20$ to $50 \mathrm{ml}$ ), then vortexed vigorously. Samples were centrifuged at $14,000 \mathrm{rpm}$ for 15 min at $4^{\circ} \mathrm{C}$. The supernatant (cytoplasmic fraction) was removed. The remaining pellet was washed several times in 1x PBS. The pellet was resuspended in $500 \mu$ of nuclear extraction buffer (10 mM HEPES, $500 \mathrm{mM} \mathrm{NaCl,} \mathrm{1 \%} \mathrm{Triton-X} \mathrm{100,} \mathrm{10 \%}$ glycerol, $1 \mathrm{mM} \mathrm{NaPPi}, 1 \mu \mathrm{g} / \mathrm{ml}$, pepstatin, $1 \mu \mathrm{g} / \mathrm{ml}$, aprotinin, $1 \mu \mathrm{g} / \mathrm{ml}$ leupeptin, $1 \mathrm{mM}$ $\mathrm{NaVO}_{4}, 1 \mathrm{mM} \mathrm{NaF}, 1 \mathrm{mM} \mathrm{PMSF}, \mathrm{ddH} 20$ to $50 \mathrm{ml}$ ), then sonicated for $30 \mathrm{~s}$ with a $1 \mathrm{~min}$ rest 8 times. The pellet was centrifuged at $14,000 \mathrm{rpm}$ for $15 \mathrm{~min}$ at $4^{\circ} \mathrm{C}$. The 
supernatant (nuclear fraction) was removed. Protein levels of extracts were quantified using the 2-D Quant Kit (GE Healthcare, Piscataway, NJ).

Cell staining, flow cytometry, and cell sorting

Single cell suspensions of thymocytes were prepared as described above. Thymocytes were stained using combinations of the following fluorochrome directly conjugated antibodies: anti-CD45-biotin (eBioscience; San Diego, CA), anti-streptavidinPacific Blue (Invitrogen; Carlsbad, CA), anti-CD44-PE-Cy5 (eBioscience), anti-CD25PE-Cy7 (eBioscience), anti-CD4-FITC (BD Biosciences Pharmingen; San Jose, CA), and anti-CD8-PE (BD Biosciences Pharmingen). SP and DP cell subpopulations were identified using anti-CD4 and anti-CD8. To identify the different DN subpopulations, anti-CD44 and anti-CD25 were determined on the CD4 CD8 population. Cells $\left(1 \times 10^{6}\right)$ were stained using the following procedure: cells were washed with PBSAz (phosphate buffered saline containing 2\% FBS and $0.2 \%$ sodium azide) and then incubated with whole rat and mouse IgG (Jackson ImmunoResearch, West Grove, PA) for 30 minutes on ice to block Fc receptors, followed by a PBSAz wash. The cells were incubated for 30 mins on ice with fluorochrome labeled antibodies. The cells were washed several times with PBSAz and fixed overnight at $4^{\circ} \mathrm{C}$ with $0.4 \%$ paraformaldehyde. The paraformaldehyde was removed and cells resuspended in PBSAz. Stained cells were analyzed using a FACSAria and FACSDiva software (BD Biosciences Pharmingen). A total of 10,000 events were collected for each sample.

For experiments represented in Figures 4 and 7, purified populations of thymocytes (DN, DP, $\left.\mathrm{CD}^{+}, \mathrm{CD}^{+}\right)$were sorted by flow cytometry using the antibodies 
listed above. Cells were stained, washed, and resuspended in FACS buffer (PBS, 1\% FBS, 25 mM HEPES, 2.5 mM EDTA). Final purity of all cell populations was in excess of $93 \%$.

Shh signaling

Shh signaling was assessed using Shh-Light 2 cells (ATCC), an NIH-3T3-derived stable cell line containing integrated Gli-luciferase and constitutive Renilla luciferase reporters. Shh-Light 2 cells $\left(1 \times 10^{4}\right.$ cells/well) were cultured in DMEM containing $10 \%$ FBS to maximal density (full contact inhibition of growth) in a 96-well plate. The media was then removed and replaced by thymic cell lysate containing $10 \mu \mathrm{g}$ of protein in 100 $\mu$ of DMEM containing $0.5 \%$ FBS and 5 mM HEPES buffer $(\mathrm{pH} 7.4)$ added to the wells in duplicate. A duplicate set of wells contained only $100 \mu \mathrm{L}$ DMEM containing $0.5 \%$ FBS and $5 \mathrm{mM}$ HEPES served as background. Another set of duplicate wells contained 10 $\mu \mathrm{g}$ protein from a control offspring to which was added $5 \mu \mathrm{M}$ cyclopamine-KAAD (Calbiochem, San Diego, CA), an inhibitor of Shh signaling, to verify that luciferase was based on Shh signaling. Cells were incubated for $36 \mathrm{~h}$. Luciferase activity was measured and normalized to a Renilla control using the Dual-Luciferase Reporter Assay System (Promega, Madison, WI) and Synergy HT Multi-Detection Microplate Reader (Biotek, Winooski, VT)

Western blots

A 20-30 $\mu \mathrm{g}$ aliquot of each whole thymic lysate or cytoplasmic/nuclear extract was boiled for 5 min to denature the proteins and electrophoresed through a 12\% Tris 
polyacrylamide gel with a 5\% stacking gel at 25 mAmps for $18 \mathrm{~h}$. Proteins were transferred onto Hybond-P membranes (Amersham Pharmacia, Piscataway, NJ) at 0.5 amps for $3 \mathrm{~h}$. Blots were washed in TBS for $5 \mathrm{~min}$ at room temperature, blocked for $1 \mathrm{~h}$ in TBS $+0.1 \%$ Tween $20(\mathrm{TBS} / \mathrm{T})$ plus $5 \%$ dry milk at room temperature and then washed three times in TBS/T. Blots were incubated overnight at $4^{\circ} \mathrm{C}$ with primary antibodies specific for anti-Shh-N-terminal (R \& D Systems, Minneapolis, MN), anti-Gli1 (Novus Biologicals, Littleton, CO), anti-Wnt10b (Abcam, Cambridge, MA), anti-active- $\beta$ catenin, clone 8E7 (Millipore, Temecula, CA), anti-phospho- $\beta$-catenin (Sigma), antiGAPDH (Santa Cruz, Santa Cruz, CA) or anti-Oct-1 (Santa Cruz) in TBS/T plus 5\% BSA or milk. The next day, blots were washed three times in TBS/T, incubated for $1 \mathrm{~h}$ at room temperature with anti-Biotin (Cell Signaling Technology, Inc., Danvers, MA) and either a goat anti-mouse IgG-horseradish peroxidase (HRP) (Millipore) or an anti-rabbit IgG-HRP antibody (Sigma). Finally, the blots were washed three times in TBS/T and developed using Phototope-HRP detection kit for western blots (Cell Signaling Technology, Inc) and bands were visualized on X-Ray film (BioMax MR, Eastman Kodak Company). Densitometric analysis was performed using Image software $(\mathrm{NIH}$, Bethesda, MD). Whole thymic and cytoplasmic protein levels were normalized to GAPDH protein levels, while nuclear extracts were normalized to Oct-1 protein levels for each sample.

Real-time RT-PCR

RNA isolation from whole thymi and thymocytes was performed using an RNeasy Mini Kit (Qiagen, Valencia, CA). Total cDNA was synthesized from 40 ng RNA/sample 
with Sensiscript Reverse Transcriptase (Qiagen) according to the instructions of the commercial supplier, and used as a target in PCR amplifications. QuantiTect Primer Assays for Ptc1, Gli1, Wnt10b, c-jun, c-fos, c-myc, and $\beta$-actin were purchased from Qiagen. All PCR reactions were performed on a Lightcycler 2.0 Real-time PCR System (Roche, Indianapolis, IN) using QuantiTect SYBR Green Master Mix (Qiagen) under the following conditions: $15 \mathrm{~min}$ at $95^{\circ} \mathrm{C}$ to activate HotStarTaq DNA polymerase then 45 cycles of $15 \mathrm{~s}$ at $94^{\circ} \mathrm{C}, 20 \mathrm{~s}$ at $55^{\circ} \mathrm{C}$, and $20 \mathrm{~s}$ at $72^{\circ} \mathrm{C}$. Melting curve analysis of PCR products was performed to verify their specificity and identity. $\beta$-actin was used as the reference gene.

\section{Statistics}

Results are expressed as mean \pm S.E.M. For Figures 1-3, 5, and 6A, a mean of the data from 3 mice/litter was taken and used as the $\mathrm{N}=1$ data for the corresponding dam. For Figures 4, 6B, and 7, a mean of the data from 2 mice/litter was taken and used as the $\mathrm{N}=1$ data for the corresponding dam. Statistical analyses comparing the values for a particular cell population, protein expression, or luciferase activity between Cd-exposed (single dose) and control offspring were performed using the t-test. An alpha value of $p \leq 0.05$ was considered significant. Relative gene expression data was analyzed using the $2^{-\Delta \Delta C}$ T method described in Livak and Schmittgen (2001). The foldchange reported includes the standard error. The luciferase assay and real-time RTPCR was repeated 2 times, while all other experiments were repeated at last three times. 


\section{RESULTS}

\section{Tissue Cd levels}

The average $\mathrm{Cd}$ concentration for the dams was $4.37 \pm 0.76$ (SEM) $\mu \mathrm{g} / \mathrm{g}$ kidney tissues, which demonstrates a low environmentally relevant exposure level that is consistent between dams. Analysis of Cd levels in the offspring was attempted; however no $\mathrm{Cd}$ was detected in the kidneys and liver Cd levels were slightly above the minimum level of detection for the ICP-OES (2.5 ppb) when livers from 3 offspring from Cd-treated dams were pooled. Cd was not detected in the offspring from control dams. This finding demonstrates that the offspring were exposed to $\mathrm{Cd}$; however, transplacental transfer was very low.

Effect of prenatal Cd exposure on thymocyte phenotype in post-natal day 0 offspring

Thymocyte phenotype of representative offspring from each litter was measured by cell surface marker expression using flow cytometry. Total thymocyte number was not significantly different between Cd-treated and control offspring $\left(7.74 \pm 0.53 \times 10^{6}\right.$ vs. $8.75 \pm 0.63 \times 10^{6}$, respectively). The number of $\mathrm{CD}^{+}$cells was significantly increased in Cd-treated offspring compared to control offspring $\left[3.09 \pm 0.44 \times 10^{6}\right.$ vs $1.48 \pm 0.21 \times 10^{6}$ $(p<0.05)$, respectively] (Figure $1 \mathrm{~A})$. The number of $\mathrm{CD}^{+}$cells showed a decreasing trend in Cd-treated offspring, though the difference was not significant $(p<0.06)$. The significantly increased number of $\mathrm{CD} 4^{+}$cells and the decreased number of $\mathrm{CD} 8^{+}$cells resulted in a nearly 10 -fold increase in the $\mathrm{CD} 4^{+} / \mathrm{CD}^{+}$ratio [Cd-treated, $93.14 \pm 22.94$ vs. control, $9.53 \pm 3.63(p<0.001)$ ] (Figure 1B). Analysis of the DN subpopulations showed that Cd-treated offspring had significantly more DN4 cells $\left(3.64 \pm 0.12 \times 10^{5}\right)$ 
compared to control offspring $\left(1.93 \pm 0.08 \times 10^{5}\right)(p<0.01)$ (Figure $\left.1 C\right)$. The DN3 population also showed an increasing trend in Cd-treated offspring, though the difference was not significant $(p<0.06)$. It should be noted that none of these effects were sex specific.

Effect of prenatal Cd exposure on Shh signaling in the thymus

Shh signaling activity was measured in whole thymic lysates using Shh-Light 2 cells, which produce luciferase in response to active Shh proteins. In the thymus, Shh production is restricted to thymic epithelial cells (TECs), thus this assay quantified Shh signaling level in TECs. Thymic lysates from Cd-treated offspring had an approximate $24 \%$ decrease in Shh signaling ability compared to control offspring (Figure 2). Cyclopamine $(5 \mu \mathrm{M})$, an inhibitor of Shh signaling, eliminated total luciferase activity in control thymic lysates (not shown), indicating that the observed luciferase activity was based on Shh signaling.

Effect of prenatal Cd exposure on Shh and Gli1 protein expression in the thymus

To determine if the decrease in Shh signaling activity was due to a decrease in Shh protein levels, thymic lysates were analyzed by western blot. In Shh producing cells, full length Shh is autocatalytically cleaved to generate an active $\mathrm{N}$-terminal fragment (Shh-N) modified by cholesterol. Using an antibody specific for Shh-N, western blot analysis demonstrated comparable levels of Shh protein in Cd-treated offspring compared to controls (Figure $3 \mathrm{~A}$ ). It should be noted that the variability 
observed in Cd-treated offspring was not correlated to sex, litter, or Cd concentration in the dam.

When Shh is present, Gli1 proteins are translocated to the nucleus where they activate target gene transcription. When Shh is absent, Gli1 proteins are sequestered in the cytoplasm by a multiprotein complex that contains suppressor of fused (SUFU). To determine if decreased Shh signaling from TECs affected Gli1 expression, protein level analysis in whole thymic lysates was performed by western blot. Gli1 protein levels were not significantly different between Cd-treated and control offspring (Figure 3B). To determine whether nuclear translocation of Gli1 was affected, total thymocytes were fractionated and Gli1 protein levels were determined in cytoplasm and nuclear fractions. The protein levels in each fraction were comparable between Cd-treated and control offspring (data not shown).

\section{Effect of prenatal Cd exposure on Shh target genes}

mRNA levels of the Shh target genes Gli1 and Ptc1 were measured in sorted thymocyte subpopulations using real-time RT-PCR. Analysis of Gli1 mRNA levels showed nearly a 5 -fold increase in relative expression in DN thymocytes of Cd-treated offspring (9.37 \pm 0.91$)$ compared to control offspring $(1.0 \pm 0.75)$, and a greater than 3 -fold increase in relative expression in $\mathrm{CD}^{+}$thymocytes of Cd-treated offspring $(7.67 \pm 0.89)$ compared to control offspring (1.0 \pm 0.97$)$ (Figure 4A). Similarly, analysis of Ptc1 mRNA showed nearly a 5 -fold increase in DN thymocytes of Cd-treated offspring (6.5 \pm 1.01$)$ compared to control offspring $(1.0 \pm 0.16)$, and a more than 6-fold increase in $\mathrm{CD}^{+}$ thymocytes of Cd-treated offspring $(15.24 \pm 1.44)$ compared to control offspring 
(1.0 \pm 1.23$)$ (Figure 4B). In summary, prenatal Cd exposure increased expression of Shh target genes, Gli1 and Ptc1, in DN and $\mathrm{CD}^{+}$thymocytes, despite decreased Shh signaling in TECs.

Effect of prenatal Cd exposure on $\beta$-catenin protein expression in thymocytes

In order to determine the effect of prenatal $\mathrm{Cd}$ exposure on the $\mathrm{Wnt} / \beta$-catenin pathway, active $\beta$-catenin (ABC) and phosphorylated $\beta$-catenin (phospho- $\beta$-catenin) protein levels were determined in the nucleus and cytoplasm, respectively. Western blot analysis showed a significant decrease in ABC levels in thymocyte nuclei of $\mathrm{Cd}$ treated offspring compared to control offspring $[2.04 \pm 0.25$ vs. $3.71 \pm 0.21 \quad(p<0.05)$, respectively] (Figure 5A). In addition, western blot analysis of phospho- $\beta$-catenin showed a significant increase in protein levels in thymocyte cytoplasm of Cd-treated offspring compared to control offspring [0.48 \pm 0.07 vs. $0.19 \pm 0.07(p<0.05)$, respectively] (Figure 5B). In summary, prenatal Cd exposure increased phosphorylation of $\beta$-catenin in the cytoplasm, resulting in decreased $A B C$ levels in the nucleus.

\section{Effect of prenatal Cd exposure on Wnt10b expression in the thymus}

To determine whether the alteration in $\beta$-catenin levels in Cd-treated offspring was due to a decrease in Wnt protein levels, translational and transcriptional levels of Wnt10b were determined by western blot and real-time RT-PCR, respectively. Wnt10b was chosen for analysis due to its expression by mouse TECs at embryonic day 15 (Pongracz et al., 2003) and its involvement in the Wnt/ $\beta$-catenin pathway (Austin et al., 1997; Van Den Berg et al., 1998). Analysis of Wnt10b protein in thymic lysates showed 
comparable levels between Cd-treated and control offspring (Figure 6A). Analysis of Wnt10b mRNA expression showed a greater than 4-fold decrease in thymi of $\mathrm{Cd}$ treated offspring compared to thymi of control offspring $(0.02 \pm 0.08$ vs. $1.0 \pm 0.57$, respectively) (Figure 6B). Protein levels of Wnt10b protein in thymocytes could not be detected by western blot, thus the Wnt10b that was detected in whole thymic lysates was from TECs.

\section{Effect of prenatal Cd exposure on Wnt/ $\beta$-catenin target genes}

Wnt $/ \beta$-catenin target genes $c$-fos, $c$-jun, and c-myc were measured in sorted thymocyte subpopulations using real-time RT-PCR. Analysis of c-fos showed a 3-fold increase in relative expression in DN and DP thymocytes of Cd-treated offspring (DN, 4.0 \pm 0.58 ; DP, $4.9 \pm 0.68$ ) compared to control offspring (DN, 1.0 \pm 0.12 ; DP, $1.0 \pm 0.35$ ), as

well as a greater than 5-fold increase in $\mathrm{CD}^{+}$thymocytes of Cd-treated offspring (12.1 \pm 1.18$)$ compared to control offspring $(1.0 \pm 0.97)$ (Figure $7 \mathrm{~A})$. Analysis of $c$-jun showed no significant difference between Cd-treated and control offspring (Figure 7B). Analysis of c-myc showed a 3-fold increase in relative expression in DN and DP thymocytes of Cd-treated offspring (DN, 4.4 \pm 0.41 ; DP, $4.4 \pm 0.44$ ) compared to control offspring (DN, 1 $\pm 0.34 ; \mathrm{DP}, 1 \pm 0.3$ ) (Figure $7 \mathrm{C}$ ). In summary, prenatal Cd exposure increased at least one $\mathrm{Wnt} / \beta$-catenin target gene in all thymocyte subpopulations analyzed except $\mathrm{CD} 8^{+}$thymocytes. 
Figure 1

A

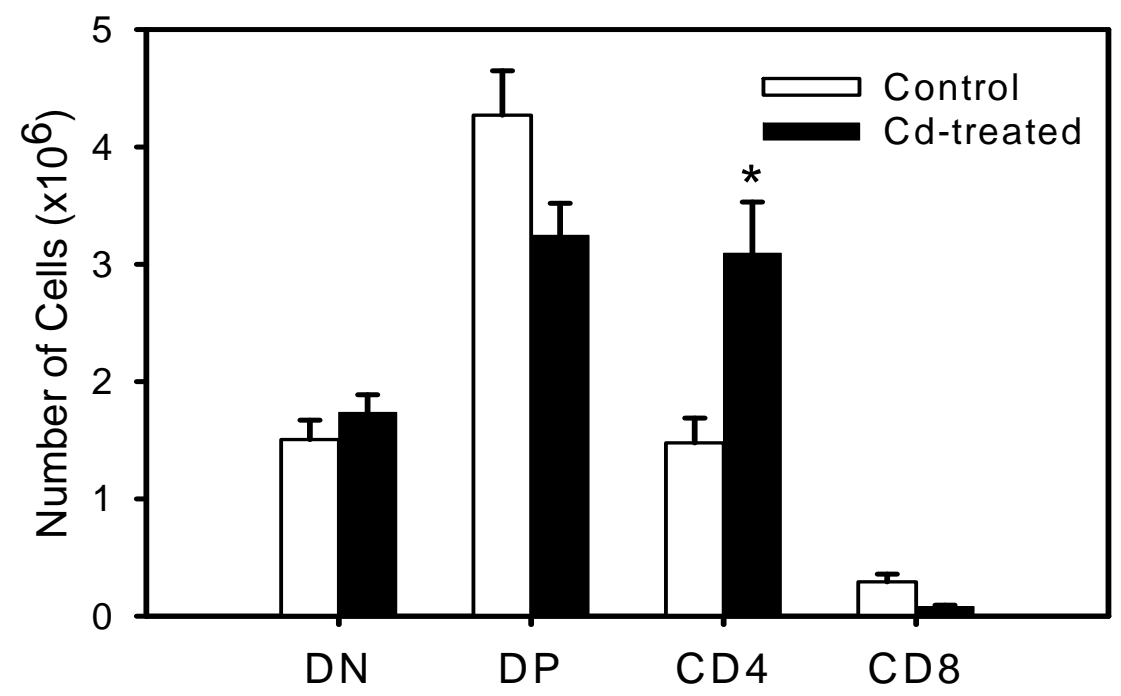

B

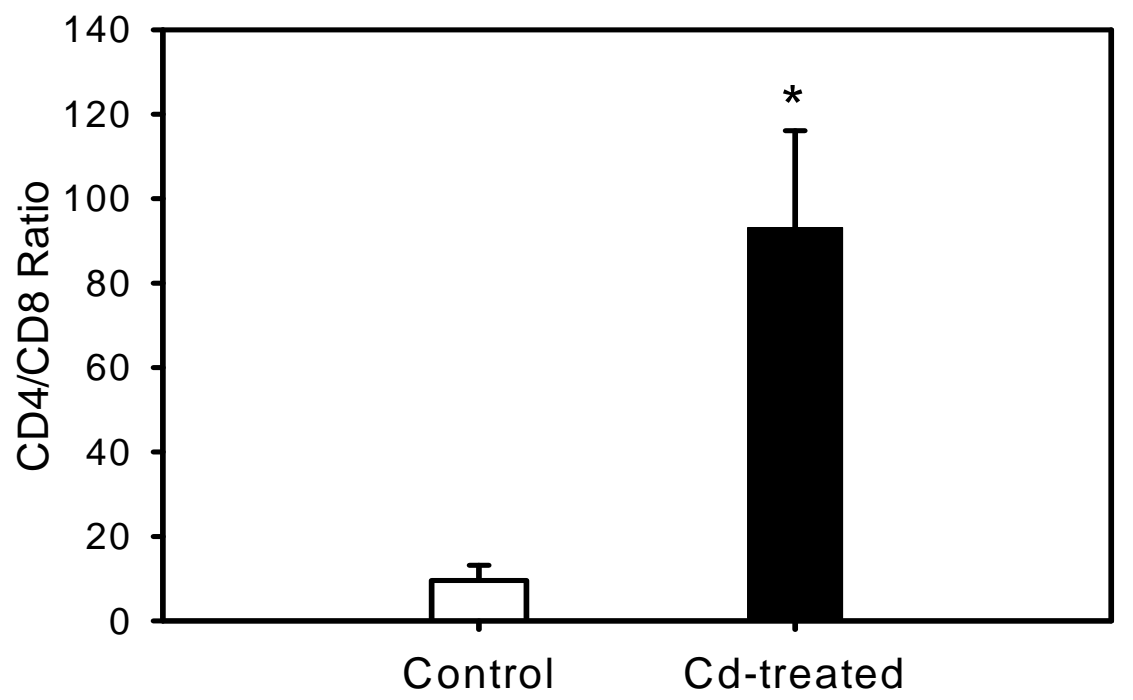

C

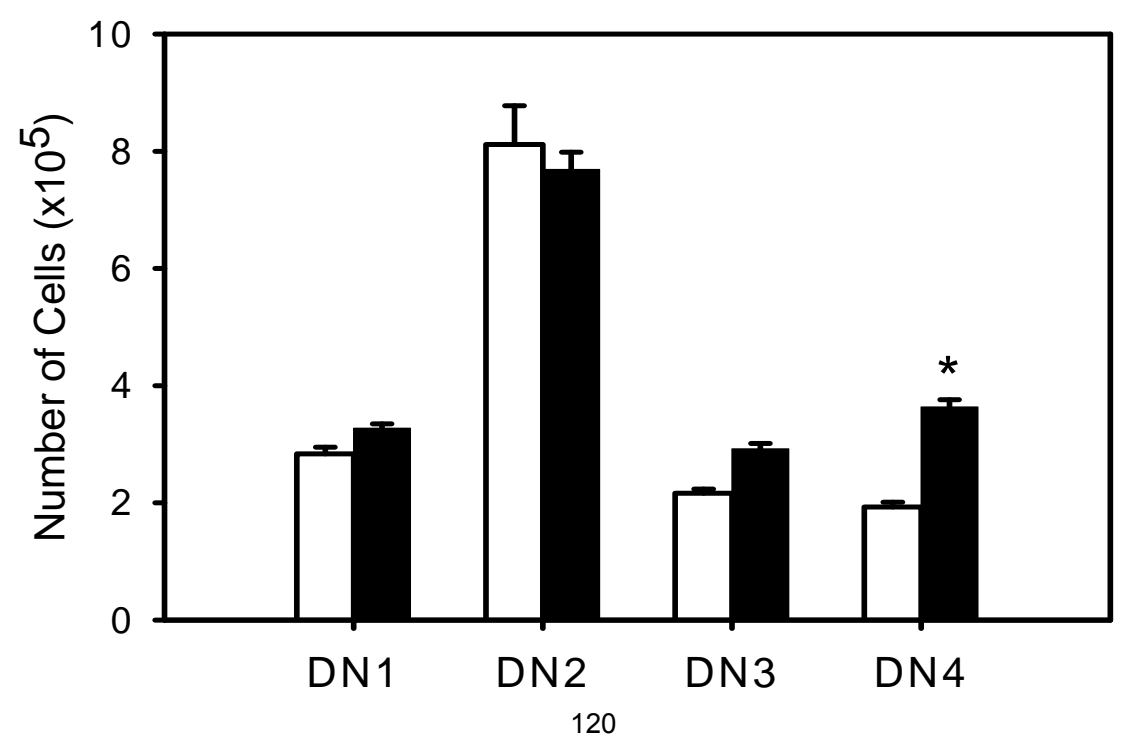


Figure 1. Thymocyte phenotype of PND0 offspring. Thymocytes were isolated from newborn mice ( $<12 \mathrm{~h}$ old) whose mothers were exposed to $10 \mathrm{ppm} \mathrm{Cd}$ throughout pregnancy. Single cell suspensions were prepared for flow cytometry analysis. Each bar represents the mean \pm SEM. Data is representative of 3 independent experiments where $\mathrm{N}=6$ in each group. (A) Thymocyte phenotype was determined based on CD4 and $\mathrm{CD} 8$ cell surface expression. ${ }^{*}, \mathrm{p}<0.05$ (B) $\mathrm{CD}^{+} / \mathrm{CD}^{+}$ratio was based on thymocyte number. ${ }^{*}, p<0.001$ (C) DN subpopulation phenotype was determined based on CD44 and CD25 cell surface expression. *,$p<0.01$ 
Figure 2

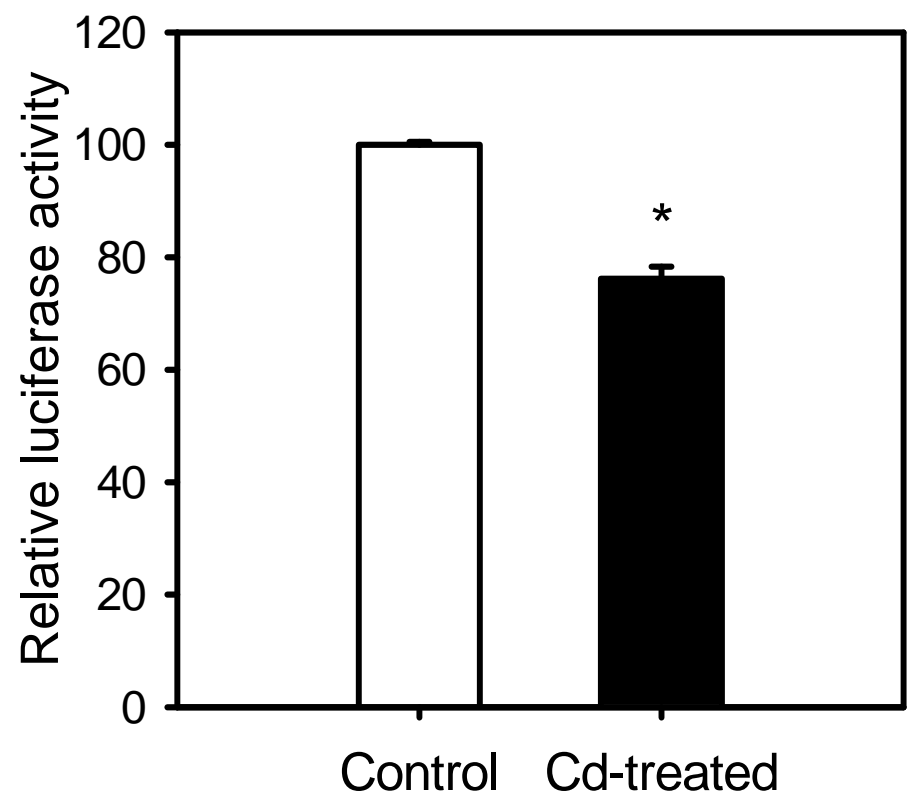


Figure 2. Shh signaling activity in thymic lysates of PNDO offspring. Thymic lysates were prepared from newborn mice ( $<12 \mathrm{~h}$ old) whose mothers were exposed to 10 ppm Cd throughout pregnancy. Shh signaling was measured by luciferase activity in Shh-Light 2 cells. Each bar represents the mean \pm SEM. The mean value of control samples was given a value of 100 . Data is representative of 2 independent experiments where $\mathrm{N}=7$ in each group. ${ }^{*}, \mathrm{p}<0.05$ 
Figure 3

A

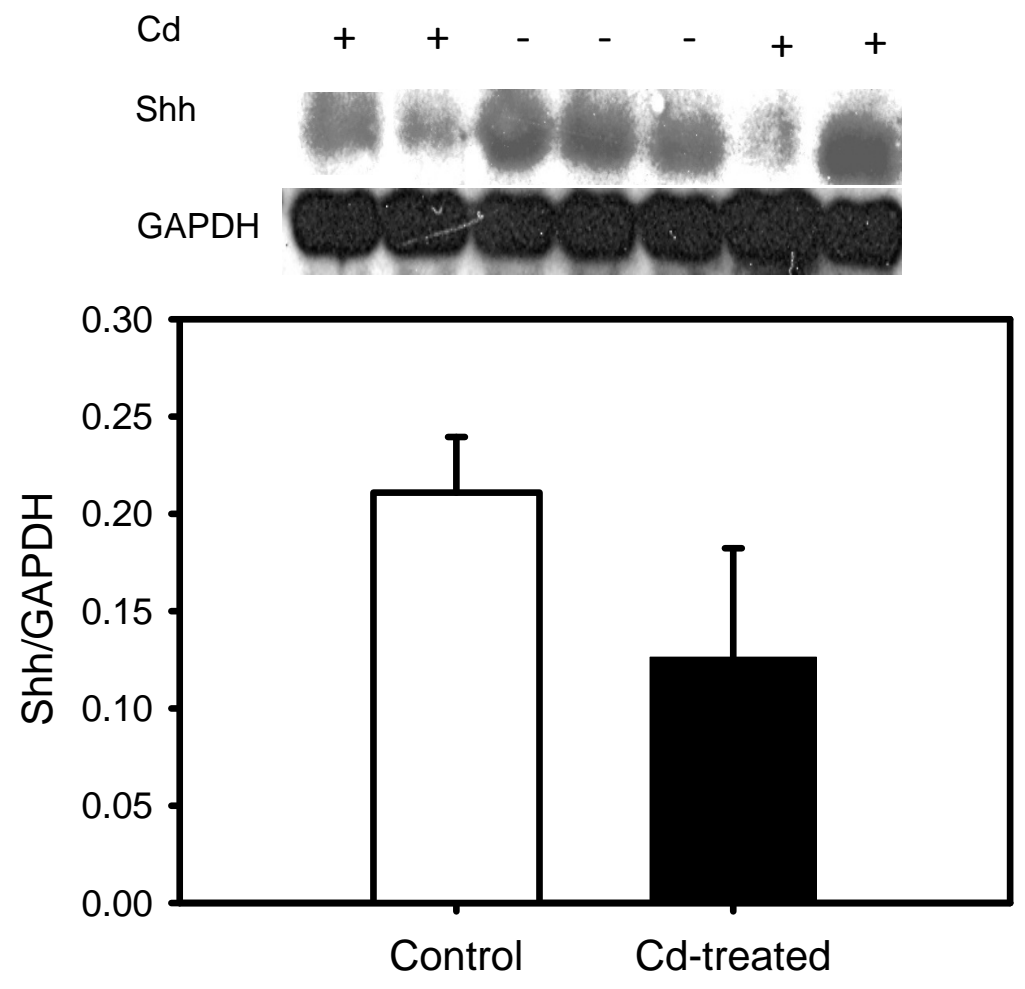

B
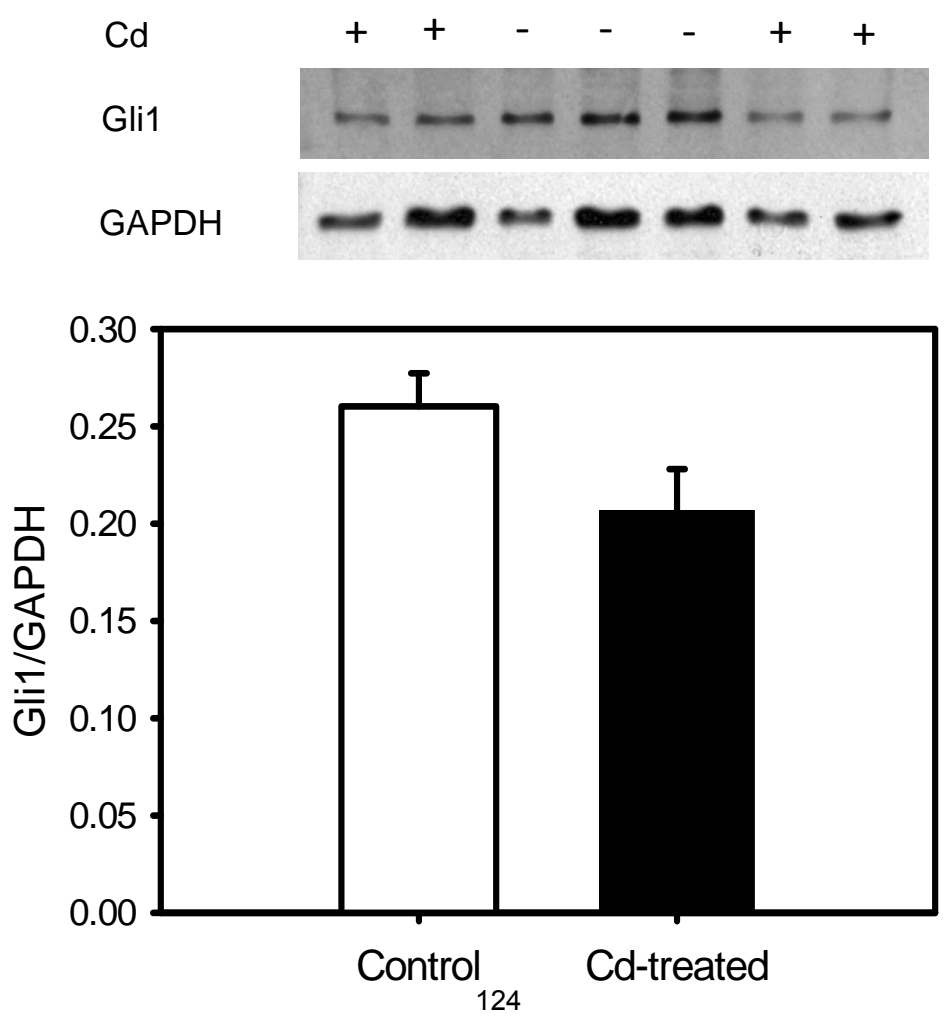
Figure 3. Shh and Gli1 expression in thymic lysates of PNDO offspring. Thymic lysates were prepared from newborn mice $(<12 \mathrm{~h}$ old $)$ whose mothers were exposed to 10 ppm Cd throughout pregnancy. Protein levels were determined by western blot. GAPDH was used as loading control. Each bar represents the mean \pm SEM. Data is representative of 3 independent experiments where $\mathrm{N}=3$ in each group. The ratio of $\mathrm{N}$ Shh protein to GAPDH protein (A) and the ratio of Gli1 protein to GAPDH protein (B) was determined using densitometry of the detected bands. 
Figure 4

A

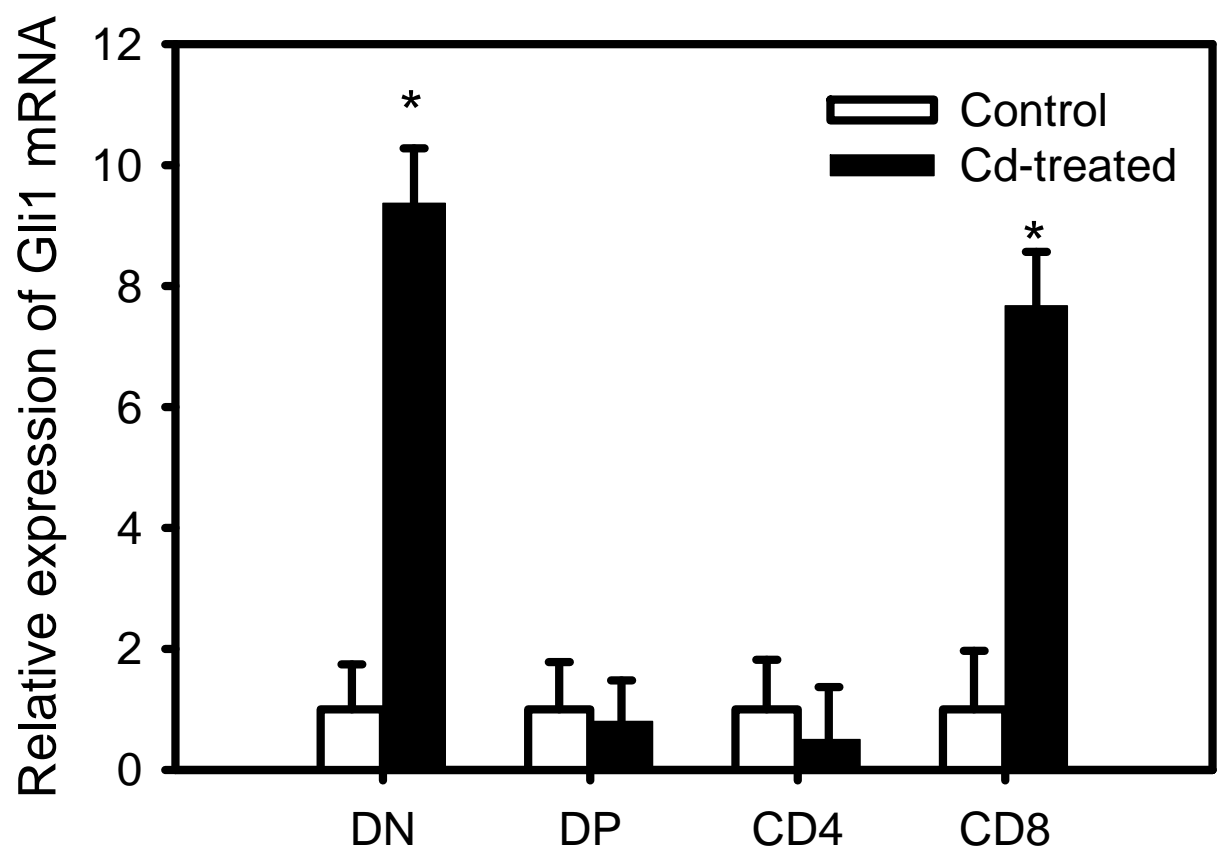

B

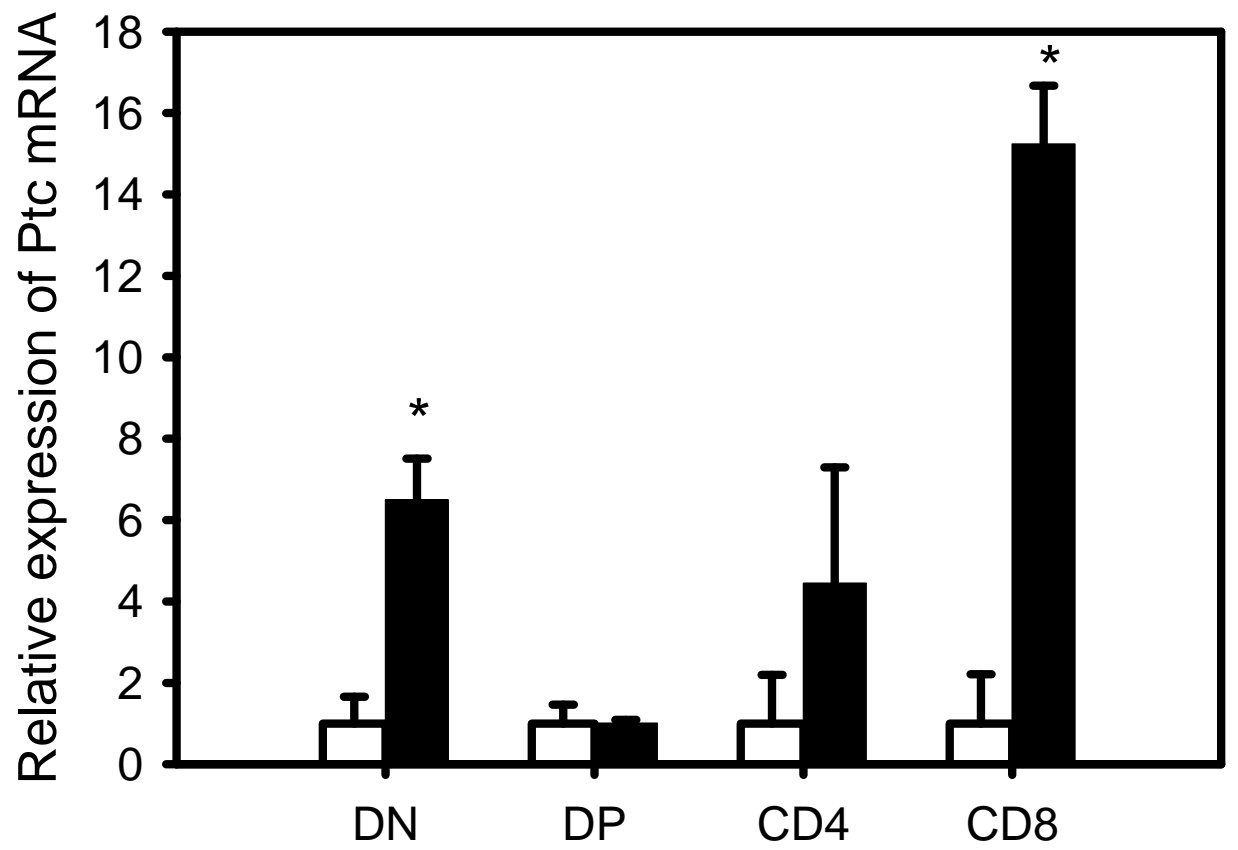


Figure 4. Hh target gene expression in thymocyte subpopulations of PND0 offspring. Primers specific for (A) Gli1 and (B) Ptc1 were used to determine their expression in DN, DP, $\mathrm{CD} 4^{+}$, and $\mathrm{CD}^{+}$thymocyte populations. $\beta$-actin was used as the reference gene. Relative quantification of target genes was calculated using $2^{-\Delta \Delta C}{ }_{T}$. Data is representative of 2 independent experiments where $\mathrm{N}=2$ in each group. ${ }^{*}, \geq 3-$ fold difference between control and Cd-treated groups. 
Figure 5

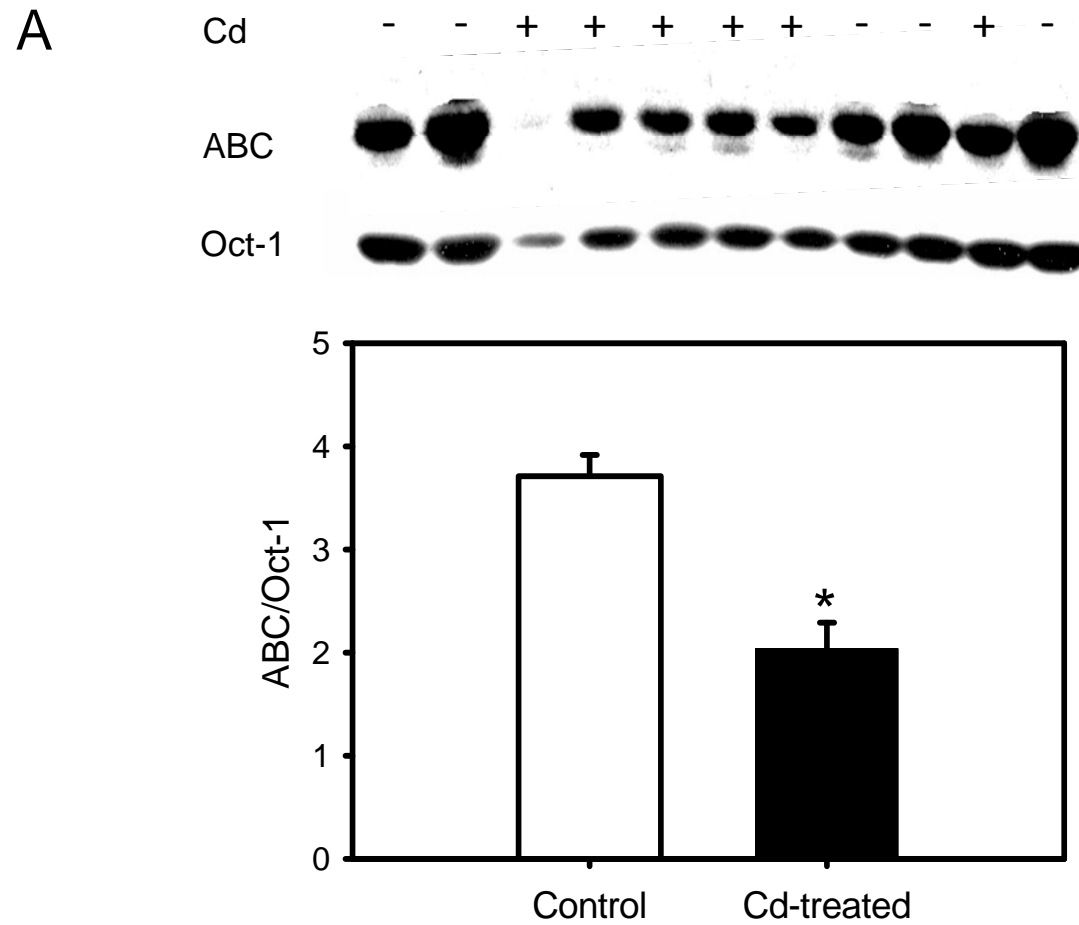

B
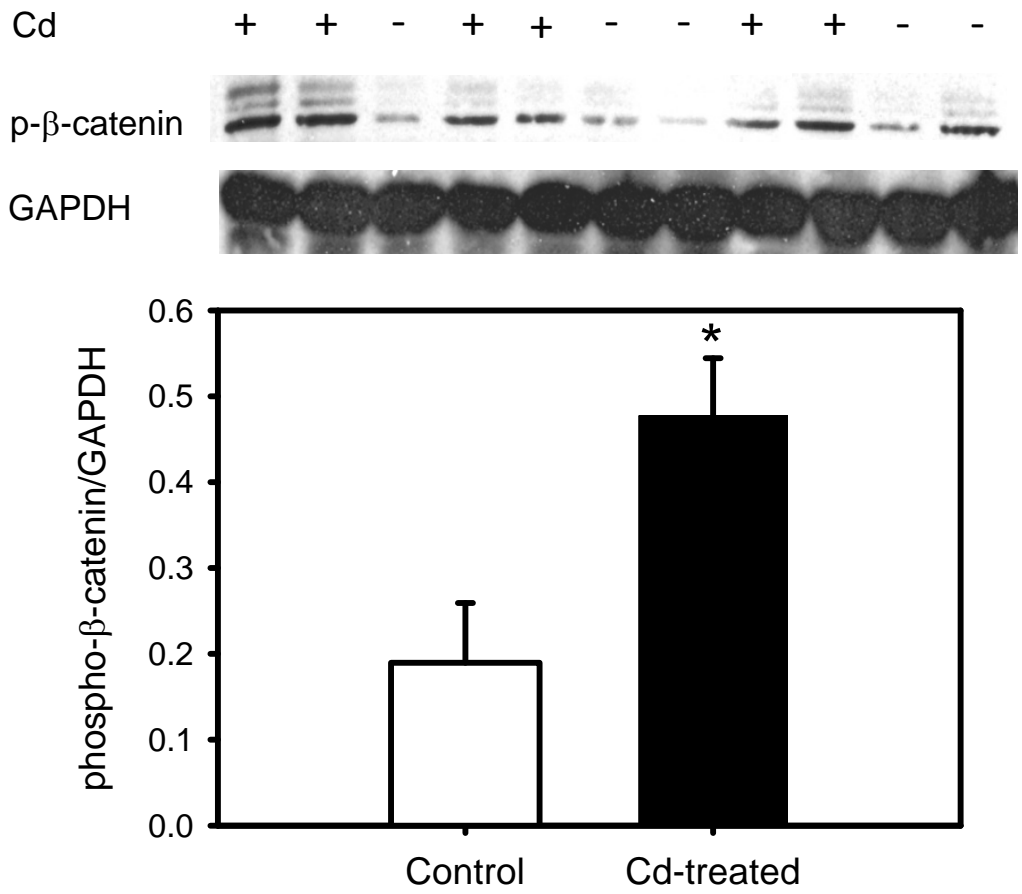
Figure 5. Active $\beta$-catenin and phospho- $\beta$-catenin expression in thymocytes of PND0 offspring. Thymocytes were isolated from newborn mice $(<12 \mathrm{~h}$ old $)$ whose mothers were exposed to $10 \mathrm{ppm} \mathrm{Cd}$ throughout pregnancy. Cytoplasmic and nuclear fractions were extracted and analyzed by western blot. GAPDH (cytoplasmic) and Oct1 (nuclear) were used as loading controls. Each bar represents the mean \pm SEM. Data is representative of 3 independent experiments where $\mathrm{N}=3$ in each group. The ratio of active $\beta$-catenin protein to Oct-1 protein in nuclear fractions $(A)$ and the ratio of phospho- $\beta$-catenin protein to GAPDH protein in cytoplasmic fractions (B) was determined using densitometry of the detected bands. *, $p<0.05$ 
Figure 6

A
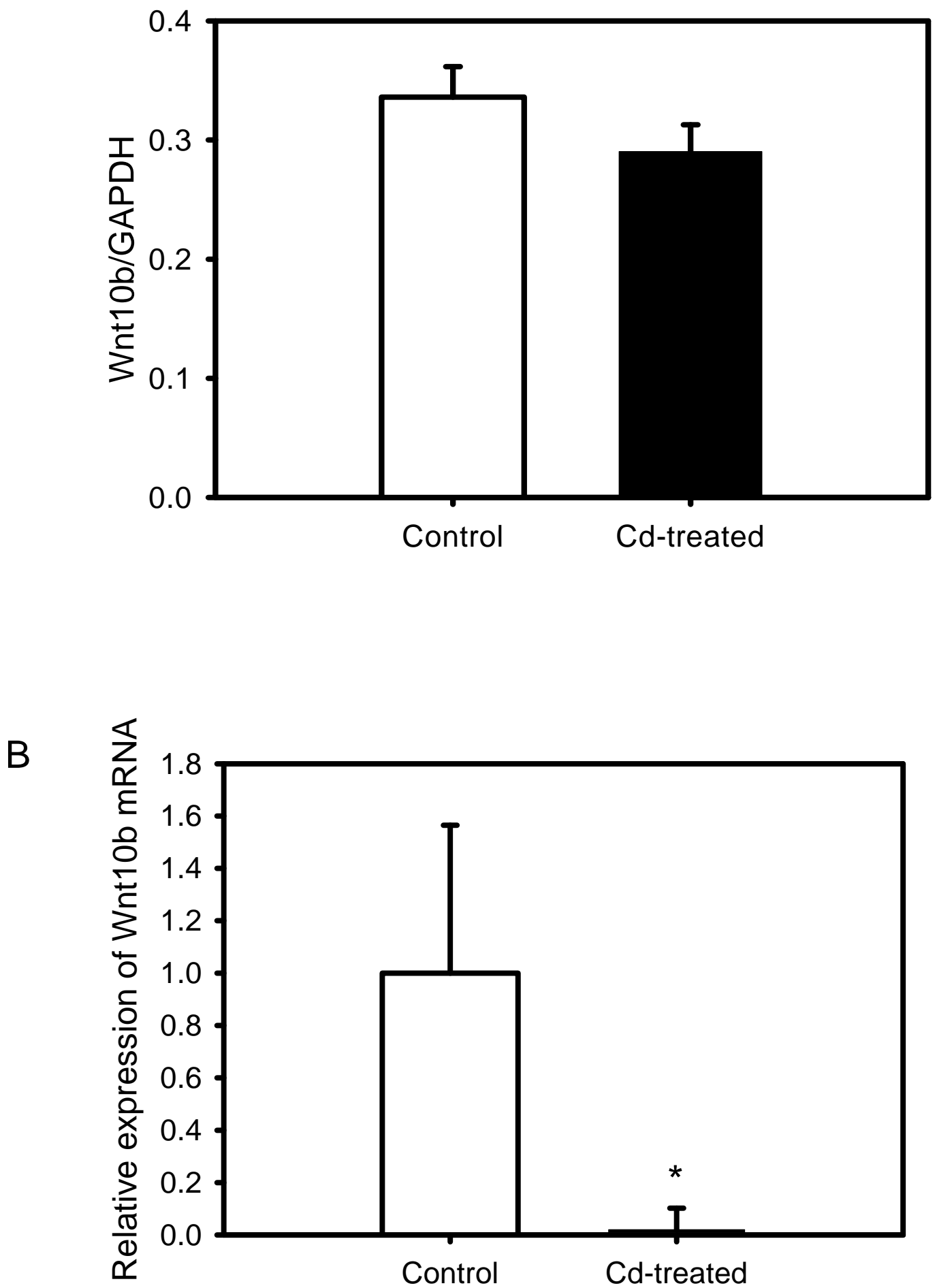
Figure 6. Wnt10b expression in thymus of PND0 offspring. (A) Thymic lysates were prepared from newborn mice $(<12 \mathrm{~h}$ old). Protein levels were determined by western blot. GAPDH was used as loading control. Each bar represents the mean \pm SEM. Data is representative of 3 independent experiments where $\mathrm{N}=3$ in each group. (B) Primers specific for Wnt10b were used to determine mRNA expression in whole thymus. $\beta$-actin was used as the reference gene. Relative quantification of target genes was calculated using $2^{-\Delta \Delta C}$. Data is representative of 2 independent experiments where $\mathrm{N}=2$ in each group. ${ }^{*}, \geq 3$-fold difference between control and Cd-treated groups. 
Figure 7
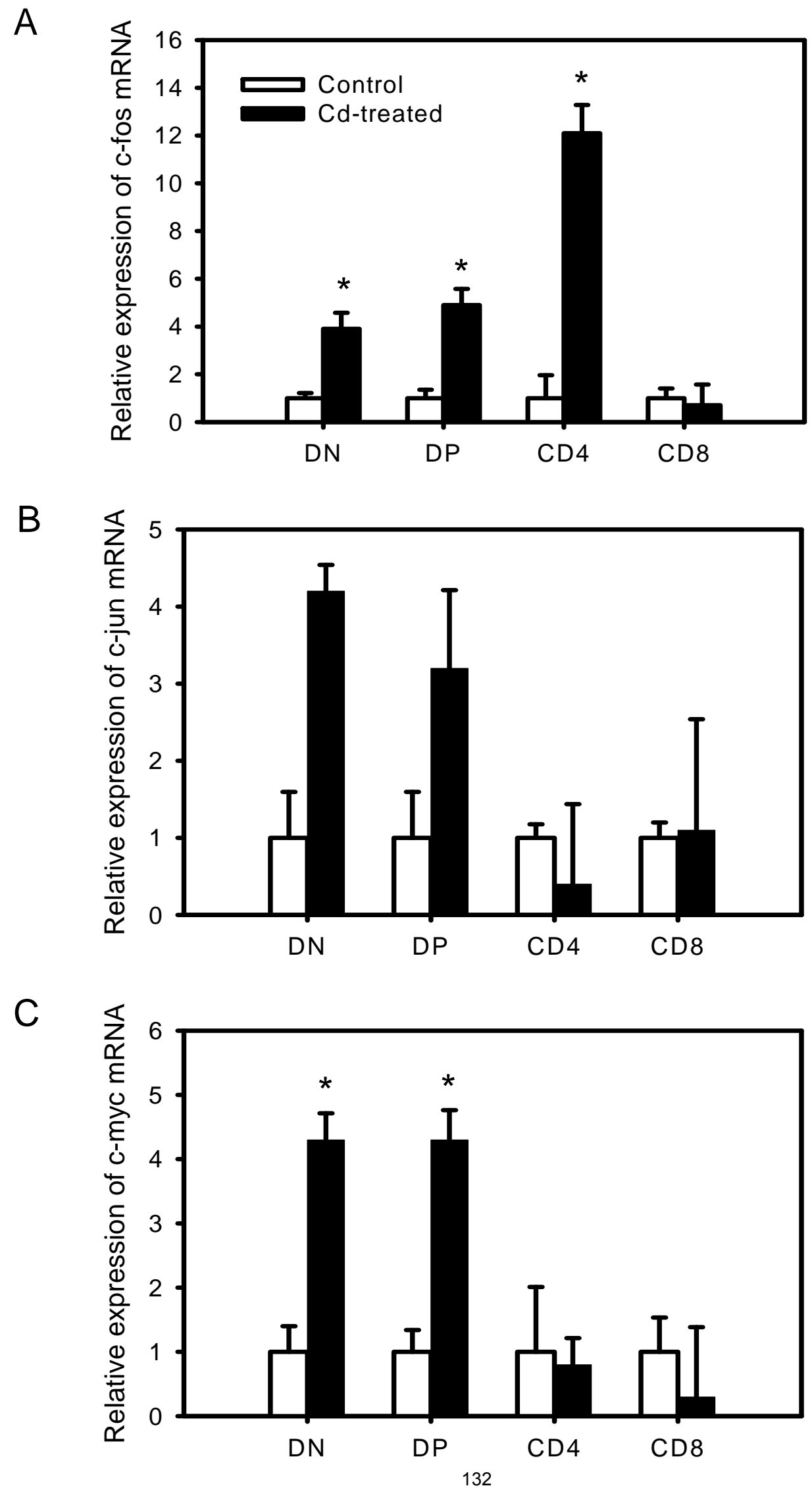
Figure 7. Wnt/ $\beta$-catenin target gene expression in thymocyte subpopulations of PNDO offspring. Primers specific for (A) c-fos, (B) c-jun, and (C) c-myc were used to determine their expression in $\mathrm{DN}, \mathrm{DP}, \mathrm{CD} 4^{+}$, and $\mathrm{CD} 8^{+}$thymocyte populations. $\beta$-actin was used as the reference gene. Relative quantification of target genes was calculated using $2^{-\Delta \Delta C}$ T. Data is representative of 2 independent experiments where $N=2$ in each group. * ${ }^{*} \geq 3$-fold difference between control and Cd-treated groups. 
Figure 8
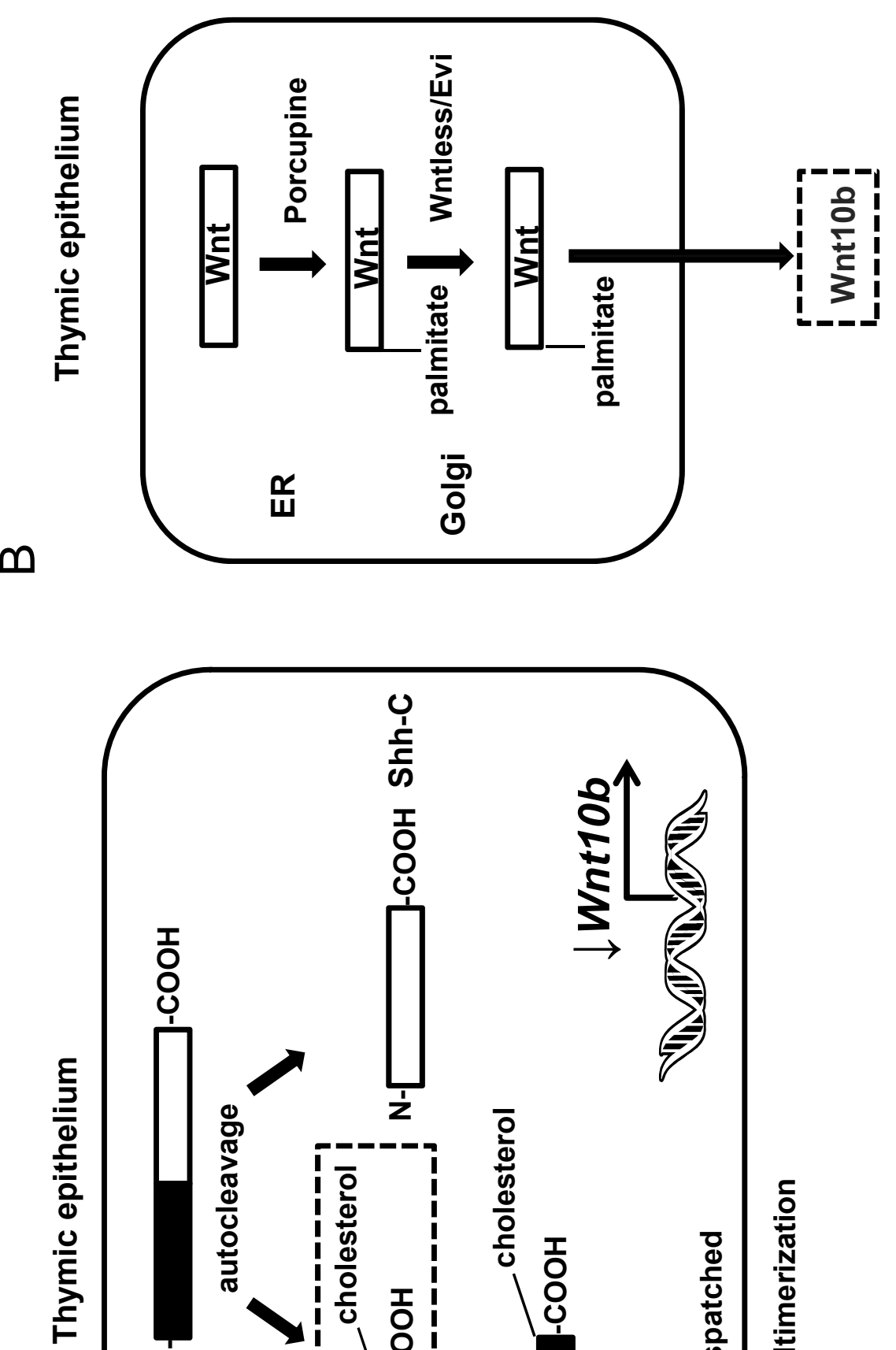
Figure 8. Proposed model for the effect of prenatal Cd exposure on Shh and Wnt/ $\beta$-catenin signaling in the thymus.

(A) Shh signaling in the thymic epithelium and thymocytes, (B) Wnt/B-catenin signaling in the thymic epithelium and thymocytes. protein or gene expression; - , inhibition of signaling; genes are italicized 


\section{DISCUSSION}

Immunotoxic effects following $\mathrm{Cd}$ exposure in adult animals are well documented; however, there have been no studies that investigate the immunomodulatory effects of gestational Cd exposure to the offspring on thymocyte development. Studies demonstrating a dysregulation of Shh (Scott et al., 2005) and Wnt/ $\beta$-catenin (Thompson et al., 2008) signaling by prenatal Cd exposure, coupled with the requirement for Shh (Outram et al., 2000) and Wnt/ $\beta$-catenin (Oosterwegel et al., 1991; Verbeek et al., 1995; Hattori et al., 1996; Ioannidis et al., 2001) in thymocyte development, led to the hypothesis that prenatal $\mathrm{Cd}$ exposure dysregulates these signaling pathways in the offspring, leading to changes in thymocyte phenotype. To our knowledge, this is the first study to link prenatal Cd exposure to changes in thymocyte development and to dysregulation of the $\mathrm{Wnt} / \beta$-catenin pathway in a mouse model.

Our ex vivo analysis of thymocyte phenotype showed that prenatal Cd exposure increased the number of $\mathrm{CD} 4^{+}$and $\mathrm{DN} 4^{+}$cells, as well as the $\mathrm{CD} 4^{+} / \mathrm{CD} 8^{+}$ratio. Other studies that have examined the effect of direct in vitro $\mathrm{Cd}$ exposure on thymocyte phenotype, however, report a decrease in DP cells (Dong et al., 2001; Pathak and Khandelwal, 2007), an increase in DN cells (Pathak and Khandelwal, 2007), and a decrease in the $\mathrm{CD}^{+} / \mathrm{CD}^{+}$ratio (Dong et al., 2001; Pathak and Khandelwal, 2007). In those studies, primary thymocytes from 3-6 week old male Balb/c mice were exposed in vitro to various $\mathrm{Cd}$ concentrations $(5-50 \mu \mathrm{M})$ for several time intervals $(3-24 \mathrm{~h})$. However, the relevance of these studies to the interpretation of those reported herein is questionable because of the differences in experimental design such as in vitro vs. in vivo exposure, Cd dose, length of exposure, mouse strain, and developmental stage of 
the exposed cells. In addition, in vitro exposure would not account for possible effects on the thymic epithelium in addition to the thymocytes that as described below, could have a significant impact on the phenotype. In our study, thymocytes are being exposed to an indirect, environmentally relevant concentration of $\mathrm{Cd}$. Although $\mathrm{Cd}$ was detected in pooled livers of the offspring, the level was close to the minimum level of detection, thus we believe that any possible direct $\mathrm{Cd}$ effect is minimal to nil. The increased $\mathrm{CD}^{+} / \mathrm{CD} 8^{+}$ratio observed in our study could have several consequences in cell-mediated immunity and T-cell host response to infection including an increased chance of developing autoimmune disease and allergies, as well as an increased susceptibility to viruses and tumor cells.

Analysis of Shh signaling showed that prenatal $\mathrm{Cd}$ exposure dysregulates several components of this pathway (Figure $8 \mathrm{~A}$ ). Shh is produced by thymic epithelial cells (TECs), while its receptor molecules Ptc and Smo are expressed by thymocytes (Outram et al., 2000), thus the decreased Shh signaling activity observed in the ShhLight 2 cell assay can be attributed to a down- regulation in signal transduction from the Shh-producing cells to the Shh-receiving cells (Figure 8A, top). The downregulation of Shh target gene Wnt10b in the whole thymus further supports an inhibitory role of prenatal Cd exposure on Shh signaling from the epithelium. Analysis of Shh protein in thymic lysates via western blot indicates that active Shh protein levels are unchanged. Several processing events must occur for proper secretion of the processed Shh (Shh$\mathrm{Np}$ ). Such events include: post-translation cleavage of the original $45 \mathrm{kDa}$ protein along with cholesterol modification of the active $19 \mathrm{kDa}$ fragment (Porter et al., 1995), palmitoylation of the $\mathrm{N}$-terminal cysteine (Pepinsky et al., 1998), requirement of the 
protein Dispatched for secretion (Burke et al., 1999), and multimerization of the Shh protein (Zeng et al., 2001). Since the antibody used in this study recognizes the cholesterol-modified form of Shh, it is unlikely that $\mathrm{Cd}$ affects this step of modification; however, any of the other steps may be altered following prenatal $\mathrm{Cd}$ exposure.

Cells near the source of Shh secretion can modulate the range of the signal by upregulating their expression of Ptc, which can sequester Shh and thereby prevent it from spreading further (Chen and Struhl, 1996). Studies determining the expression pattern of Smo and the Gli genes suggest that the thymocytes responding to the Shh signal are DN cells and CD8 ${ }^{+}$cells (Outram et al., 2000). In addition, analysis of Shh"thymi showed that Shh is necessary for efficient proliferation of DN thymocytes (Shah et al., 2004). In our study, analysis of Shh target genes Ptc1 and Gli1 in Cd-treated offspring showed a significant upregulation of both genes in the $\mathrm{DN}$ and $\mathrm{CD}^{+}$cell population, while there was no difference in either gene in the DP and CD4 ${ }^{+}$cell populations (Figure 8A, bottom). Based on our data, we hypothesized that in an environment where Shh signaling is decreased, $\mathrm{DN}$ and $\mathrm{CD}^{+}$cells may upregulate Ptc1 in order to sequester the limited signal. Upregulation of Gli1 transcription indicates that Shh signaling is increased in the $\mathrm{DN}$ and $\mathrm{CD}^{+}$cell populations, despite the decreased Shh signal from the TECs and the unchanged protein level of Gli1 in the total thymocyte population. Analysis of thymocyte phenotype showed a significant increase in the DN4 cell population as well as a trended increase in the DN3 cell population, thus, increased Shh signaling may contribute to increased proliferation of these cell populations. The role that Shh signaling plays in single positive cells has not been well defined, however, one study showed that Shh signaling in developing thymocytes 
influences TCR repertoire selection and differentiation from DP to SP cells (Rowbotham et al., 2007). Specifically, in $\mathrm{Shh}^{-/}$fetal thymic organ cultures, the $\mathrm{CD}^{+} / \mathrm{CD} 8^{+}$ratio was increased, therefore, the decreased Shh signal from TECs in the present study is likely contributing to the increased $\mathrm{CD} 4^{+} / \mathrm{CD} 8^{+}$ratio observed in prenatal $\mathrm{Cd}$-treated offspring. In addition, the increased transcription of Ptc1 and Gli1 in $\mathrm{CD}^{+}$and no change in these genes in $\mathrm{CD} 4^{+}$cells may also contribute to the significantly increased $\mathrm{CD} 4^{+} / \mathrm{CD} 8^{+}$ratio observed in thymocyte phenotype analysis.

Analysis of Wnt/ $\beta$-catenin signaling showed that prenatal $\mathrm{Cd}$ exposure dysregulates several components of this pathway (Figure 8B). Wnt proteins begin as precursors containing an $\mathrm{N}$-terminal hydrophobic signal peptide that directs the immature protein to the endoplasmic reticulum (ER). In the ER, the signal peptide is cleaved by a protease and the Wnt protein is modified by the addition of sugars and lipids by the acyl-transferase porcupine (Tanaka, 2000). This is required for proper secretion to occur. The attachment of a palmitate moiety to a conserved cysteine residue on the Wnts, which converts them into hydrophobic proteins, is essential for their biological activity (Willert et al., 2003; Zhai et al., 2004). Transport and secretion of the Wnt protein in secretory vesicles is controlled by the multi-pass transmembrane protein Wntless (Wls)/Evenness interrupted (Evi) (Ching and Nusse, 2006). TECs are the main source of Wnt proteins in the thymus, while the Wnt receptor, Frizzled (Fz), is mostly found on thymocytes, which indicates a crosstalk between TECs and thymocytes (Pongracz et al., 2003). In our study, we observed unchanged protein levels of Wnt10b in TECs (Figure 8B, top), along with decreased $W n t / \beta$-catenin signaling in thymocytes as determined by increased cytoplasmic phospho- $\beta$-catenin and decreased nuclear 
ABC (Figure 8B, bottom). These findings suggest that prenatal $\mathrm{Cd}$ treatment is affecting the palmitoylation processing or secretion steps of Wnt in the epithelium. The decrease in properly processed/secreted Wnt ligand would lead to degradation of $\beta$ catenin in the cytoplasm, which is observed in prenatal Cd-treated offspring. In addition, others have demonstrated that $A B C$ enhances the generation of $C D 8^{+}$cells from DP cells (Mulroy et al., 2003), thus decreased ABC may be responsible for the increased $\mathrm{CD}^{+} / \mathrm{CD} 8^{+}$ratio we observed in prenatal $\mathrm{Cd}$-treated offspring.

Cd has been shown to be mitogenic and to influence the expression of genes, especially the cellular proto-oncogenes, also known as the immediate early response genes, that encode nuclear transcription factors and influence subsequent expression of other genes (Vogt and Bos, 1989). Cd-induced accumulation of transcripts of c-fos, cjun, and c-myc has been reported in several cell types of animals and humans (Jin and Ringertz, 1990; Tang and Enger, 1993; Matsuoka and Call, 1995; Wang and Templeton, 1998; Achanzar et al., 2000; Joseph et al., 2001). These genes are generally associated with cell proliferation, thus their induction indicates a mechanism by which Cd may promote the development of cancer. In our study, c-fos was upregulated in DN, DP, and $\mathrm{CD} 4^{+}$cells, but was unaffected in $\mathrm{CD}^{+}$cells; c-myc was upregulated in DN and DP cells, but was unaffected in $\mathrm{CD} 4^{+}$and $\mathrm{CD} 8^{+}$cells; and c-jun was unaffected in all cell populations (Figure 8B, bottom). In summation, a significant increase in at least one of these immediate early response genes was present in every thymocyte population analyzed except for the $\mathrm{CD}^{+}$population. Interestingly, thymocyte phenotype analysis showed that this was the only population that had a trended decrease following prenatal $\mathrm{Cd}$ exposure. Although c-fos, c-jun, and c-myc are known 
Wnt $/ \beta$-catenin target genes, it is unlikely that their upregulation is due to an increase in $A B C$ levels since prenatal $C d$ exposure caused a decrease in $A B C$ and an increase in phospho- $\beta$-catenin protein levels in total thymocytes when analyzed via western blot. $\beta$-catenin, together with DNA-binding T cell factor/lymphoid enhancer factor (TCF/LEF) family proteins, functions as a transcription factor to control Wnt target genes, thus, prenatal Cd exposure may be upregulating TCF/LEF or downregulating repressors such as Groucho/TLE which would result in upregulation of the proto-oncogenes. It has also been demonstrated that overexpression of cellular proto-oncogenes by $\mathrm{Cd}$ is mediated by the elevation of intracellular levels of superoxide anion, hydrogen peroxide, and calcium (Joseph et al., 2001).

In summary, we exposed pregnant mice to an environmentally relevant dose of Cd throughout pregnancy and analyzed the effects on thymocyte phenotype of the offspring. We also examined the effect of prenatal $\mathrm{Cd}$ exposure on two signaling pathways necessary for proper thymocyte maturation. We demonstrated that prenatal Cd exposure alters Shh and Wnt/ $\beta$-catenin signaling resulting in aberrant thymocyte development. It is likely that prenatal $\mathrm{Cd}$ exposure affects the processing and/or secretion of Shh and Wnt proteins in the thymic epithelium resulting in an attenuated signal in both pathways as demonstrated by a decrease in Gli:luciferase activity and a decrease in nuclear $A B C$ levels. The overall upregulation of immediate early response genes suggests that prenatal $\mathrm{Cd}$ also affects an intracellular component of the thymocyte independent of the effects on the thymic epithelium. Although it is known that Shh and $\mathrm{Wnt} / \beta$-catenin signaling influences fetal thymocyte development, the specific time points at which they play a role and the regulation of their components, as 
well as their interaction with each other need further investigation. In addition to the thymus, $\mathrm{Hh}$ and $\mathrm{Wnt} / \beta$-catenin signaling is necessary for proper development of the kidney (Stark et al., 1994; Kang et al., 1997), bone (Gao et al., 2001; Gong et al., 2001; Loughlin et al., 2004), lung (Pepicelli et al., 1998; Tebar et al., 2001; Mucenski et al., 2003; Okubo and Hogan, 2004), and prostate (Podlasek et al., 1999; Truica et al., 2000; Lamm et al., 2002; Mulholland et al., 2002; Chesire and Isaacs, 2003; Freestone et al., 2003; Berman et al., 2004), all of which are target organs of Cd toxicity (Bernard, 2008). Due to $\mathrm{Hh}$ and $\mathrm{Wnt} / \beta$-catenin signaling being highly conserved among organ systems, it is plausible that prenatal $\mathrm{Cd}$ exposure disrupts these pathways in other organs, resulting in developmental malformations, increased cell proliferation, and possibly cancer. 


\section{ACKNOWLEDGEMENTS}

The authors wish to thank Courtney Williamson and the Dr. John Hollander lab for their technical assistance with the luciferase assay. 


\section{REFERENCES}

Achanzar, W. E., Achanzar, K. B., Lewis, J. G., Webber, M. M., and Waalkes, M. P. (2000). Cadmium induces c-myc, p53, and c-jun expression in normal human prostate epithelial cells as a prelude to apoptosis. Toxicol Appl Pharmacol 164, 291-300.

Amit, S., Hatzubai, A., Birman, Y., Andersen, J. S., Ben-Shushan, E., Mann, M., BenNeriah, Y., and Alkalay, I. (2002). Axin-mediated CKI phosphorylation of betacatenin at Ser 45: a molecular switch for the Wnt pathway. Genes \& development 16, 1066-1076.

Austin, T. W., Solar, G. P., Ziegler, F. C., Liem, L., and Matthews, W. (1997). A role for the Wnt gene family in hematopoiesis: expansion of multilineage progenitor cells. Blood 89, 3624-3635.

Behrens, J., von Kries, J. P., Kuhl, M., Bruhn, L., Wedlich, D., Grosschedl, R., and Birchmeier, W. (1996). Functional interaction of beta-catenin with the transcription factor LEF-1. Nature 382, 638-642.

Berman, D. M., Desai, N., Wang, X., Karhadkar, S. S., Reynon, M., Abate-Shen, C., Beachy, P. A., and Shen, M. M. (2004). Roles for Hedgehog signaling in androgen production and prostate ductal morphogenesis. Developmental biology 267, 387-398.

Bernard, A. (2008). Cadmium \& its adverse effects on human health. The Indian journal of medical research 128, 557-564. 
Bhanot, P., Brink, M., Samos, C. H., Hsieh, J.-C., Wang, Y., Macke, J. P., Andrew, D., Nathans, J., and Nusse, R. (1996). A new member of the frizzled family from Drosophila functions as a Wingless receptor. Nature 382, 225-230.

Borgman, R. F., Au, B., and Chandra, R. K. (1986). Immunopathology of chronic cadmium administration in mice. International journal of immunopharmacology $\mathbf{8}$, 813-817.

Burke, R., Nellen, D., Bellotto, M., Hafen, E., Senti, K. A., Dickson, B. J., and Basler, K. (1999). Dispatched, a novel sterol-sensing domain protein dedicated to the release of cholesterol-modified hedgehog from signaling cells. Cell 99, 803-815.

Chen, Y., and Struhl, G. (1996). Dual Roles for Patched in Sequestering and Transducing Hedgehog. Cell 87, 553-563.

Chen, Y., and Struhl, G. (1998). In vivo evidence that Patched and Smoothened constitute distinct binding and transducing components of a Hedgehog receptor complex. Development 125, 4943-4948.

Chesire, D. R., and Isaacs, W. B. (2003). Beta-catenin signaling in prostate cancer: an early perspective. Endocrine-related cancer 10, 537-560.

Ching, W., and Nusse, R. (2006). A dedicated Wnt secretion factor. Cell 125, 432-433.

Cook, M. E. (1995). Anthropogenic Sources of Cadmium in Canada. National Workshop on Cadmium Transport Into Plants, Canadian Network of Toxicology Centres, Ottawa, Ontario, Canada.

Dong, S., Shen, H. M., and Ong, C. N. (2001). Cadmium-induced apoptosis and phenotypic changes in mouse thymocytes. Molecular and cellular biochemistry 222, 11-20. 
Freestone, S. H., Marker, P., Grace, O. C., Tomlinson, D. C., Cunha, G. R., Harnden, P., and Thomson, A. A. (2003). Sonic hedgehog regulates prostatic growth and epithelial differentiation. Developmental biology 264, 352-362.

Gao, B., Guo, J., She, C., Shu, A., Yang, M., Tan, Z., Yang, X., Guo, S., Feng, G., and He, L. (2001). Mutations in IHH, encoding Indian hedgehog, cause brachydactyly type A-1. Nature genetics 28, 386-388.

Gao, Z. H., Seeling, J. M., Hill, V., Yochum, A., and Virshup, D. M. (2002). Casein kinase I phosphorylates and destabilizes the beta-catenin degradation complex. Proceedings of the National Academy of Sciences of the United States of America 99, 1182-1187.

Gong, Y., Slee, R. B., Fukai, N., Rawadi, G., Roman-Roman, S., Reginato, A. M., Wang, H., Cundy, T., Glorieux, F. H., Lev, D., Zacharin, M., Oexle, K., Marcelino, J., Suwairi, W., Heeger, S., Sabatakos, G., Apte, S., Adkins, W. N., Allgrove, J., Arslan-Kirchner, M., Batch, J. A., Beighton, P., Black, G. C., Boles, R. G., Boon, L. M., Borrone, C., Brunner, H. G., Carle, G. F., Dallapiccola, B., De Paepe, A., Floege, B., Halfhide, M. L., Hall, B., Hennekam, R. C., Hirose, T., Jans, A., Juppner, H., Kim, C. A., Keppler-Noreuil, K., Kohlschuetter, A., LaCombe, D., Lambert, M., Lemyre, E., Letteboer, T., Peltonen, L., Ramesar, R. S., Romanengo, M., Somer, H., Steichen-Gersdorf, E., Steinmann, B., Sullivan, B., Superti-Furga, A., Swoboda, W., van den Boogaard, M. J., Van Hul, W., Vikkula, M., Votruba, M., Zabel, B., Garcia, T., Baron, R., Olsen, B. R., and Warman, M. L. (2001). LDL receptor-related protein 5 (LRP5) affects bone accrual and eye development. Cell 107, 513-523. 
Hattori, N., Kawamoto, H., Fujimoto, S., Kuno, K., and Katsura, Y. (1996). Involvement of transcription factors TCF-1 and GATA-3 in the initiation of the earliest step of T cell development in the thymus. The Journal of experimental medicine 184, $1137-1147$.

Hovland, D. N., Jr., Machado, A. F., Scott, W. J., Jr., and Collins, M. D. (1999). Differential sensitivity of the SWV and C57BL/6 mouse strains to the teratogenic action of single administrations of cadmium given throughout the period of anterior neuropore closure. Teratology. 60, 13-21.

Ikeda, S., Kishida, S., Yamamoto, H., Murai, H., Koyama, S., and Kikuchi, A. (1998). Axin, a negative regulator of the Wnt signaling pathway, forms a complex with GSK-3beta and beta-catenin and promotes GSK-3beta-dependent phosphorylation of beta-catenin. The EMBO journal 17, 1371-1384.

Ingham, P. W., and McMahon, A. P. (2001). Hedgehog signaling in animal development: paradigms and principles. Genes and Development 15, 30593087.

Ioannidis, V., Beermann, F., Clevers, H., and Held, W. (2001). The beta-catenin--TCF-1 pathway ensures CD4(+)CD8(+) thymocyte survival. Nature immunology 2, 691697.

Jacquillet, G., Barbier, O., Rubera, I., Tauc, M., Borderie, A., Namorado, M. C., Martin, D., Sierra, G., Reyes, J. L., Poujeol, P., and Cougnon, M. (2007). Cadmium causes delayed effects on renal function in the offspring of cadmiumcontaminated pregnant female rats. American journal of physiology 293, F14501460. 
Jin, P., and Ringertz, N. R. (1990). Cadmium induces transcription of proto-oncogenes c-jun and c-myc in rat L6 myoblasts. J. Biol. Chem. 265, 14061-14064.

Jin, T., Lu, J., and Nordberg, M. (1998). Toxicokinetics and biochemistry of cadmium with special emphasis on the role of metallothionein. Neurotoxicology. 19, 529535.

Joseph, P., Muchnok, T. K., Klishis, M. L., Roberts, J. R., Antonini, J. M., Whong, W. Z., and Ong, T. (2001). Cadmium-induced cell transformation and tumorigenesis are associated with transcriptional activation of c-fos, c-jun, and c-myc protooncogenes: role of cellular calcium and reactive oxygen species. Toxicol Sci $\mathbf{6 1}$, 295-303.

Kang, S., Graham, J. M., Jr., Olney, A. H., and Biesecker, L. G. (1997). GLI3 frameshift mutations cause autosomal dominant Pallister-Hall syndrome. Nature genetics $15,266-268$.

Lafuente, A., Gonzalez-Carracedo, A., Romero, A., and Esquifino, A. I. (2003). Effect of cadmium on lymphocyte subsets distribution in thymus and spleen. J Physiol Biochem. 59, 43-48.

Lamm, M. L., Catbagan, W. S., Laciak, R. J., Barnett, D. H., Hebner, C. M., Gaffield, W., Walterhouse, D., Iannaccone, P., and Bushman, W. (2002). Sonic hedgehog activates mesenchymal Gli1 expression during prostate ductal bud formation. Developmental biology 249, 349-366.

Lauwerys, R., Buchet, J. P., Roels, H., Bernard, A., and Gennart, J. P. (1986). [Biological aspects of occupational exposure to cadmium and several other metals]. Revue d'epidemiologie et de sante publique 34, 280-285. 
Liu, J., Liu, Y., Habeebu, S. S., and Klaassen, C. D. (1999). Metallothionein-null mice are highly susceptible to the hematotoxic and immunotoxic effects of chronic $\mathrm{CdCl} 2$ exposure. Toxicology and applied pharmacology 159, 98-108.

Livak, K. J., and Schmittgen, T. D. (2001). Analysis of relative gene expression data using real-time quantitative PCR and the 2(-Delta Delta $\mathrm{C}(\mathrm{T})$ ) Method. Methods (San Diego, Calif 25, 402-408.

Loughlin, J., Dowling, B., Chapman, K., Marcelline, L., Mustafa, Z., Southam, L., Ferreira, A., Ciesielski, C., Carson, D. A., and Corr, M. (2004). Functional variants within the secreted frizzled-related protein 3 gene are associated with hip osteoarthritis in females. Proceedings of the National Academy of Sciences of the United States of America 101, 9757-9762.

Mackova, N. O., Lenikova, S., Fedorocko, P., Brezani, P., and Fedorockova, A. (1996). Effects of cadmium on haemopoiesis in irradiated and non-irradiated mice: 2. Relationship to the number of circulating blood cells and haemopoiesis. Physiological research / Academia Scientiarum Bohemoslovaca 45, 101-106.

Marigo, V., Davey, R. A., Zuo, Y., Cunningham, J. M., and Tabin, C. J. (1996). Biochemical evidence that patched is the Hedgehog receptor. Nature 384, 176179.

Matsuoka, M., and Call, K. M. (1995). Cadmium-induced expression of immediate early genes in LLC-PK1 cells. Kidney international 48, 383-389.

Minetti, A., and Reale, C. A. (2006). Sensorimotor developmental delays and lower anxiety in rats prenatally exposed to cadmium. J Appl Toxicol 26, 35-41. 
Morselt, A. F. W., Leene, W., DeGroot, C., Kipp, J. B. A., Evers, M., Roelofsen, A. M., and Bosch, K. S. (1988). Differences in immunological susceptibility to cadmium toxicity between two rat strains as demonstrated with cell biological methods. Effect of cadmium on DNA synthesis of thymus lymphocytes. Toxicology 48, 127139.

Mucenski, M. L., Wert, S. E., Nation, J. M., Loudy, D. E., Huelsken, J., Birchmeier, W., Morrisey, E. E., and Whitsett, J. A. (2003). beta-Catenin is required for specification of proximal/distal cell fate during lung morphogenesis. The Journal of biological chemistry 278, 40231-40238.

Mulholland, D. J., Cheng, H., Reid, K., Rennie, P. S., and Nelson, C. C. (2002). The androgen receptor can promote beta-catenin nuclear translocation independently of adenomatous polyposis coli. The Journal of biological chemistry 277, 1793317943.

Mulroy, T., Xu, Y., and Sen, J. M. (2003). beta-Catenin expression enhances generation of mature thymocytes. International immunology 15, 1485-1494.

Nordberg, G. F. (2006). Lung cancer and exposure to environmental cadmium. Lancet Oncol. 7, 99-101.

Novak, A., and Dedhar, S. (1999). Signaling through beta-catenin and Lef/Tcf. Cell Mol Life Sci 56, 523-537.

Okamura, R. M., Sigvardsson, M., Galceran, J., Verbeek, S., Clevers, H., and Grosschedl, R. (1998). Redundant regulation of $T$ cell differentiation and TCRalpha gene expression by the transcription factors LEF-1 and TCF-1. Immunity 8, 11-20. 
Okubo, T., and Hogan, B. L. (2004). Hyperactive Wnt signaling changes the developmental potential of embryonic lung endoderm. Journal of biology 3, 11 .

Oosterwegel, M., van de Wetering, M., Dooijes, D., Klomp, L., Winoto, A., Georgopoulos, K., Meijlink, F., and Clevers, H. (1991). Cloning of murine TCF-1, a T cell-specific transcription factor interacting with functional motifs in the CD3epsilon and $\mathrm{T}$ cell receptor alpha enhancers. The Journal of experimental medicine 173, 1133-1142.

Outram, S. V., Varas, A., Pepicelli, C. V., and Crompton, T. (2000). Hedgehog signaling regulates differentiation from double-negative to double-positive thymocyte. Immunity. 13, 187-197.

Pathak, N., and Khandelwal, S. (2007). Impact of cadmium in T lymphocyte subsets and cytokine expression: differential regulation by oxidative stress and apoptosis. Biometals.

Pepicelli, C. V., Lewis, P. M., and McMahon, A. P. (1998). Sonic hedgehog regulates branching morphogenesis in the mammalian lung. Curr Biol 8, 1083-1086.

Pepinsky, R. B., Zeng, C., Wen, D., Rayhorn, P., Baker, D. P., Williams, K. P., Bixler, S. A., Ambrose, C. M., Garber, E. A., Miatkowski, K., Taylor, F. R., Wang, E. A., and Galdes, A. (1998). Identification of a palmitic acid-modified form of human Sonic hedgehog. The Journal of biological chemistry 273, 14037-14045.

Podlasek, C. A., Barnett, D. H., Clemens, J. Q., Bak, P. M., and Bushman, W. (1999). Prostate development requires Sonic hedgehog expressed by the urogenital sinus epithelium. Developmental biology 209, 28-39. 
Pongracz, J., Hare, K., Harman, B., Anderson, G., and Jenkinson, E. J. (2003). Thymic epithelial cells provide WNT signals to developing thymocytes. European journal of immunology 33, 1949-1956.

Porter, J. A., von Kessler, D. P., Ekker, S. C., Young, K. E., Lee, J. J., Moses, K., and Beachy, P. A. (1995). The product of hedgehog autoproteolytic cleavage active in local and long-range signalling. Nature 374, 363-366.

Prozialeck, W. C., Lamar, P. C., and Lynch, S. M. (2003). Cadmium alters the localization of $\mathrm{N}$-cadherin, E-cadherin, and [beta]-catenin in the proximal tubule epithelium. Toxicology and Applied Pharmacology 189, 180-195.

Rowbotham, N. J., Hager-Theodorides, A. L., Cebecauer, M., Shah, D. K., Drakopoulou, E., Dyson, J., Outram, S. V., and Crompton, T. (2007). Activation of the Hedgehog signaling pathway in T-lineage cells inhibits TCR repertoire selection in the thymus and peripheral T-cell activation, pp. 3757-3766.

Schilham, M. W., Wilson, A., Moerer, P., Benaissa-Trouw, B. J., Cumano, A., and Clevers, H. C. (1998). Critical involvement of Tcf-1 in expansion of thymocytes. J Immunol 161, 3984-3991.

Scott, W. J., Jr., Schreiner, C. M., Goetz, J. A., Robbins, D., and Bell, S. M. (2005). Cadmium-induced postaxial forelimb ectrodactyly: association with altered sonic hedgehog signaling. Reproductive toxicology (Elmsford, N.Y 19, 479-485.

Shah, D. K., Hager-Theodorides, A. L., Outram, S. V., Ross, S. E., Varas, A., and Crompton, T. (2004). Reduced thymocyte development in sonic hedgehog knockout embryos. J Immunol 172, 2296-2306. 
Soukupova, D., Dostal, M., and Piza, J. (1991). Developmental toxicity of cadmium in mice. II. Immunotoxic effects. Functional and developmental morphology 1, 3136.

Staal, F. J., Meeldijk, J., Moerer, P., Jay, P., van de Weerdt, B. C., Vainio, S., Nolan, G. P., and Clevers, H. (2001). Wnt signaling is required for thymocyte development and activates Tcf-1 mediated transcription. European journal of immunology 31, 285-293.

Stark, K., Vainio, S., Vassileva, G., and McMahon, A. P. (1994). Epithelial transformation of metanephric mesenchyme in the developing kidney regulated by Wnt-4. Nature $372,679-683$.

Stone, D. M. (1996). The tumour-suppressor gene patched encodes a candidate receptor for Sonic hedgehog. Nature 384, 129-134.

Taipale, J., Cooper, M. K., Maiti, T., and Beachy, P. A. (2002). Patched acts catalytically to suppress the activity of Smoothened. Nature 418, 892-896.

Tanaka, K., Koji, O, Makoto,A, Norbert, P, Tatsuhiko, K (2000). The evolutionarily conserved porcupine gene family is involved in the processing of the Wnt family. European Journal of Biochemistry 267, 4300-4311.

Tang, N., and Enger, M. D. (1993). Cd(2+)-induced c-myc mRNA accumulation in NRK49F cells is blocked by the protein kinase inhibitor $\mathrm{H} 7$ but not by HA1004, indicating that protein kinase $C$ is a mediator of the response. Toxicology $\mathbf{8 1}$, 155-164. 
Tebar, M., Destree, O., de Vree, W. J., and Ten Have-Opbroek, A. A. (2001). Expression of Tcf/Lef and sFrp and localization of beta-catenin in the developing mouse lung. Mechanisms of development 109, 437-440.

Thevenod, F., Wolff, N. A., Bork, U., Lee, W. K., and Abouhamed, M. (2007). Cadmium induces nuclear translocation of beta-catenin and increases expression of c-myc and Abcb1a in kidney proximal tubule cells. Biometals 20, 807-820.

Thompson, J., Wong, L., Lau, P. S., and Bannigan, J. (2008). Adherens junction breakdown in the periderm following cadmium administration in the chick embryo: distribution of cadherins and associated molecules. Reproductive toxicology (Elmsford, N.Y 25, 39-46.

Truica, C. I., Byers, S., and Gelmann, E. P. (2000). Beta-catenin affects androgen receptor transcriptional activity and ligand specificity. Cancer research 60, 47094713.

Van Den Berg, D. J., Sharma, A. K., Bruno, E., and Hoffman, R. (1998). Role of members of the Wnt gene family in human hematopoiesis. Blood 92, 3189-3202.

van den Heuvel, M., and Ingham, P. W. (1996). smoothened encodes a receptor-like serpentine protein required for hedgehog signalling. Nature $\mathbf{3 8 2}, 547-551$.

Verbeek, S., Izon, D., Hofhuis, F., Robanus-Maandag, E., te Riele, H., van de Wetering, M., Oosterwegel, M., Wilson, A., MacDonald, H. R., and Clevers, H. (1995). An HMG-box-containing T-cell factor required for thymocyte differentiation. Nature 374, 70-74.

Vogt, P. K., and Bos, T. J. (1989). The oncogene jun and nuclear signalling. Trends in biochemical sciences 14, 172-175. 
Wang, Z., and Templeton, D. M. (1998). Induction of c-fos proto-oncogene in mesangial cells by cadmium. The Journal of biological chemistry $\mathbf{2 7 3}, \mathbf{7 3 - 7 9 .}$

Webb, M. (1972). Persistence of stored Cd2+ in the livers and kidneys of female rats during pregnancy. J Reprod Fertil 30, 99-103.

Willert, K., Brown, J. D., Danenberg, E., Duncan, A. W., Weissman, I. L., Reya, T., Yates, J. R., 3rd, and Nusse, R. (2003). Wnt proteins are lipid-modified and can act as stem cell growth factors. Nature $\mathbf{4 2 3}, 448-452$.

Yu, R. M., Lin, C. C., Chan, P. K., Chow, E. S., Murphy, M. B., Chan, B. P., Muller, F., Strahle, U., and Cheng, S. H. (2006). Four-dimensional imaging and quantification of gene expression in early developing zebrafish (Danio rerio) embryos. Toxicol Sci. 90, 529-538.

Zeng, X., Goetz, J. A., Suber, L. M., Scott, W. J., Jr., Schreiner, C. M., and Robbins, D. J. (2001). A freely diffusible form of Sonic hedgehog mediates long-range signalling. Nature 411, 716-720.

Zhai, L., Chaturvedi, D., and Cumberledge, S. (2004). Drosophila wnt-1 undergoes a hydrophobic modification and is targeted to lipid rafts, a process that requires porcupine. The Journal of biological chemistry 279, 33220-33227. 


\section{CHAPTER 3: Prenatal cadmium exposure alters postnatal immune cell development and function}


Prenatal cadmium exposure alters postnatal immune cell development and function

Miranda L. Hanson, Kathleen M. Brundage, Rosana Schafer, Rodney A. Brundage, and John B. Barnett

Department of Microbiology, Immunology and Cell Biology, West Virginia University School of Medicine, Morgantown, WV 26506

Running title: Prenatal cadmium affects immune cells

Correspondence to:

John B. Barnett, Ph.D.

Department of Microbiology, Immunology and Cell Biology

PO Box 9177

West Virginia University

Morgantown, WV. 26506-9177

(T). 304-293-4029; (F) 304-293-7823

jbarnett@hsc.wvu.edu 


\section{ABSTRACT}

Cadmium (Cd) is an environmental pollutant due to its widespread and continual use. Cd is generally found in low concentrations in the environment, while its concentration in cigarette smoke is high. Although evidence demonstrates that adult exposure to Cd causes changes in the immune system, there are limited reports in the literature of immunomodulatory effects of prenatal exposure to $\mathrm{Cd}$. This study was designed to investigate the effects of prenatal exposure to $\mathrm{Cd}$ on the immune system of the offspring. Pregnant C57BI/6 mice were exposed to an environmentally relevant dose of $\mathrm{Cd}(10 \mathrm{ppm})$ and the effects on the immune system of the offspring were assessed at two time points following birth (PND 14 and 49). Thymocyte and splenocyte phenotypes were analyzed by flow cytometry. Cytokine production of splenic $\mathrm{T}$ cells was determined by ELISA. Prenatal Cd exposure increased the number of double negative (DN; $\left.C D 4^{-} \mathrm{CD}^{-}\right)$thymocytes, specifically the DN1 subpopulation (CD44 ${ }^{+}$ $\mathrm{CD}^{\circ}{ }^{\circ}$ ), at PND 14 and 49. In the spleen, prenatal Cd exposure decreased the number of macrophages in male offspring at both time points. Cytokine analysis of splenic $T$ cells demonstrated that prenatal Cd exposure decreased IL-2 and IL-4 production in female offspring at PND14. At PND49, IL-2 production remained decreased in Cdexposed females while IFN- $\gamma$ production was decreased in both male and female $\mathrm{Cd}$ treated offspring. These findings suggest that even a very low level of exposure to $\mathrm{Cd}$ during gestation can result in long term detrimental effects on the immune system of the offspring, and these effects are to some extent sex-specific.

Key words: cadmium, prenatal exposure, thymocytes, splenocytes, cytokines 


\section{INTRODUCTION}

Cadmium (Cd) is a heavy metal that poses a hazard to human health due to its toxicity. There is sufficient evidence in humans to classify $\mathrm{Cd}$ and $\mathrm{Cd}$ compounds as carcinogens based on epidemiological studies demonstrating a link between $\mathrm{Cd}$ and lung, and possibly prostate, cancer (IARC, 2004). Exposure to the heavy metal and its compounds primarily occurs in workplaces such as mining, smelting, processing, and battery manufacturing, whereas non-occupational exposures come from various foods, contaminated water, and tobacco smoke. Smokers generally have Cd blood levels 4-5 times those of non-smokers (Elinder et al., 1976).

Cd levels in the environment vary widely due to its ability to be transported through air, water, and soil. Humans normally absorb $\mathrm{Cd}$ into the body either by ingestion or inhalation (Lauwerys et al., 1986). The daily intake is estimated to be approximately $10-50 \mu \mathrm{g}$, but can reach levels of $200-1000 \mu \mathrm{g}$ in highly contaminated areas (Nordberg, 2006). The average Cd intake from food generally varies between 8$25 \mu \mathrm{g}$ per day (Olsson et al., 2002), while a cigarette contains 1-2 $\mu \mathrm{g}$. Cd levels in soils, particularly areas in which phosphate fertilizers have been applied, can range from 10 to $200 \mu \mathrm{g} / \mathrm{g}$ (Cook, 1995).

As a result of humans not having an effective $\mathrm{Cd}$ elimination pathway, the biologic half-life of $\mathrm{Cd}$ in the body is estimated to be $15-20$ years (Jin et al., 1998). Excessive $\mathrm{Cd}$ accumulation in the body often results in diseases such as kidney failure, respiratory disease, neurological disorders, and occasionally death (Waalkes et al., 1992). Although pharmacokinetic studies have demonstrated that $\mathrm{Cd}$ does not readily reach the fetus, it accumulates in high concentrations in the placenta (Piasek et al., 
2001). Teratological effects associated with Cd exposure reported for humans are limited; however, maternal exposure to environmental $\mathrm{Cd}$, higher placental concentration (Loiacono et al., 1992), and/or fetal Cd exposure (Frery et al., 1993) has been associated with lower birth weights in humans. Moreover, the teratological effects of $\mathrm{Cd}$ in rodents have been extensively documented (Hovland et al., 1999; Scott et al., 2005; Minetti and Reale, 2006; Jacquillet et al., 2007).

There have been numerous studies on the immunomodulatory effects of $\mathrm{Cd}$ in humans and experimental animals; however, the findings remain controversial (Descotes, 1992). This conflict amongst findings may be attributed to varying doses, route of administration, length of $\mathrm{Cd}$ treatment, and sensitivity of immune systems between different animal species. The thymus, the primary site of T-cell production, is a target organ of Cd-induced toxicity (Morselt et al., 1988). Thymocytes mature through a series of stages defined by expression of cell surface markers CD4 and CD8. The most immature thymocytes are $\mathrm{CD} 4^{-} \mathrm{CD} 8^{-}$double-negative (DN). This population gives rise to $\mathrm{CD} 4^{+} \mathrm{CD} 8^{+}$double-positive (DP) cells, which then give rise to mature $\mathrm{CD} 4^{+} \mathrm{CD} 8^{-}$singlepositive (SP) and CD4 ${ }^{-} D 8^{+}$SP cells. The DN population can be further subdivided in mice based on the expression of surface markers CD25 and CD44: CD44 ${ }^{+} C D 25^{-}$(DN1) cells differentiate into $\mathrm{CD} 44^{+} \mathrm{CD} 25^{+}(\mathrm{DN} 2)$ cells, which then develop into $\mathrm{CD}_{4} 4^{-}$ $\mathrm{CD}^{+} 5^{+}$(DN3) cells, which differentiate into the $\mathrm{CD}^{-\mathrm{CD}^{-}}{ }^{\circ}$ (DN4) population. Following Cd-treatment, damage to the thymus as well as changes in the proliferation rate of thymocytes in adult rats results (Morselt et al., 1988). In adult mice, Dong (2001) observed a decrease in DP cells. Pathak and Khandelwal (2007a) also demonstrated that Cd exposure decreased the DP population and increased the number of DN cells. 
In vivo studies exposing adult male rats to varying concentrations of $\mathrm{Cd}(0-100 \mathrm{ppm})$ demonstrated that lower doses of $\mathrm{Cd}$ inhibited humoral and cellular immune responses, while higher concentrations had a stimulatory effect (Lafuente et al., 2004). Analysis of oxidative stress and apoptosis showed that splenic cells appeared more susceptible than thymus cells to the adverse effects of Cd both in vitro (Pathak and Khandelwal, 2006a; Pathak and Khandelwal, 2006b) and in vivo (Pathak and Khandelwal, 2007b).

Despite the numerous studies demonstrating the effects of $\mathrm{Cd}$ on the adult immune system, there have been limited reports on the effect of $\mathrm{Cd}$ exposure during gestation on the immune system of the offspring. We have previously shown that prenatal exposure to $\mathrm{Cd}$ affects thymocyte development of newborn ( $<12 \mathrm{~h}$ old) offspring (Hanson et al, unpublished). This study was designed to investigate the continued effects of prenatal exposure to $\mathrm{Cd}$ on the immune system of the offspring. Pregnant mice were exposed to an environmentally relevant dose of $\mathrm{Cd}(10 \mathrm{ppm})$ and the effects on the immune system of the offspring were assessed at two time points following birth [post-natal day (PND) 14 and 49] to evaluate the effects in relation to developmental stage. In addition, whether the observed prenatal effects on the immune system were sex-specific was determined. 


\section{MATERIALS AND METHODS}

\section{Breeding and Dosing Methodology}

C57BI/6 mice at 8-10 weeks of age were obtained from Hilltop Lab Animals, Inc. (Scottsdale, PA). The C57BI/6 strain of mouse was used for these experiments due to its reported teratogenic susceptibility to Cd treatment (Hovland et al., 1999). Mice were allowed to acclimate on site for at least one week. Two females were placed in a cage with one male for 72 hours to maximize pregnancy rate. Females were inspected for a vaginal plug and if present, this day was declared as gestational day 0 . Ten dams were used as controls, having free access to deionized distilled water $\left(\mathrm{ddH}_{2} \mathrm{O}\right)$, while ten additional dams had free access to $10 \mathrm{ppm}$ of $\mathrm{Cd}$ as $\mathrm{CdCl}_{2}$ (Sigma-Aldrich; St. Louis, MO) dissolved in $\mathrm{ddH}_{2} \mathrm{O}$. The dose of $10 \mathrm{ppm}$ was chosen because it is the greatest concentration that will elicit immunomodulatory effects in adult rodents without causing systemic effects (Lafuente et al., 2003). Cd administration was stopped at birth. At PND14 and 49, 3 offspring (at least 1 male and 1 female) selected from each of the litters were euthanized and thymi and spleens were removed. Mice born from a different set of dams were euthanized at PND49 to ensure adequate sample size. The PND14 time point was chosen to determine if any longer term effects of prenatal exposure to Cd were evident early in life and PND49 was chosen to assess the effects of prenatal $\mathrm{Cd}$ exposure at the mouse adult stage. This time point would approximate a younger post-pubescent human which should have a fully developed robust immune response. All offspring were weaned at PND21 and the dams were euthanized. 
Tissue Isolation and Cell Preparation

Thymi and spleens were harvested from euthanized mice and single cell suspensions prepared. The organs from each mouse were kept separate. Red blood cells were lysed using an ammonium chloride lysis buffer. Viable cells were enumerated using trypan blue and a hemacytometer.

Cd load

A group of dams whose litters were not used in the present study, but were dosed in the same manner, were euthanized following partuition to determine $\mathrm{Cd}$ load. To measure $\mathrm{Cd}$ content, kidney samples were dissolved in $2 \mathrm{ml}$ of $70 \%$ nitric acid. The acidified samples were neutralized in $5 \mathrm{ml}$ of $\mathrm{ddH}_{2} \mathrm{O}$ and filtered through Whatman no.1 paper. Samples were then diluted to volume with $\mathrm{dd}_{2} \mathrm{O}$ in a $25 \mathrm{ml}$ volumetric flask. $\mathrm{Cd}$ concentrations were measured using an inductively coupled plasma optical emission spectrometry (ICP-OES) (model P400 Perkin Elmer, Shelton, CT). The minimum level of detection of the ICP-OES for $\mathrm{Cd}$ is $2.5 \mathrm{ppb}$. The purpose of this assay was to determine how much Cd was retained in the kidneys of the dams to verify that the dams were consuming approximately equal amounts of water, and thus, $\mathrm{Cd}$ dosing was consistent between dams.

\section{Cell staining and flow cytometry}

Single cell suspensions of thymocytes and splenocytes were prepared as described above. Thymocytes were stained using combinations of the following fluorochrome directly conjugated antibodies: anti-CD45-biotin (eBioscience; San Diego, 
CA), anti-streptavidin-Pacific Blue (Invitrogen; Carlsbad, CA), anti-CD44-PE-Cy5 (eBioscience), anti-CD25-PE-Cy7 (eBioscience), anti-CD4-FITC (BD Biosciences Pharmingen; San Jose, CA), and anti-CD8-PE (BD Biosciences Pharmingen). SP and DP cell subpopulations were identified using anti-CD4 and anti-CD8. To identify the different DN subpopulations, anti-CD44 and anti-CD25 were determined on the CD4 CD8 population. Splenocytes were stained using combinations of the following directly conjugated Abs: anti-CD4-FITC (BD Biosciences Pharmingen), anti-CD8-PE (BD Biosciences Pharmingen), anti-F4/80-APC-Alexa Fluor 750 (eBioscience), anti-Gr1Alexa Fluor 700 (eBioscience), and anti-B220-PE-Cy5 (BD Biosciences Pharmingen). Cells $\left(1 \times 10^{6}\right)$ were stained using the following procedure: cells were washed with PBSAz (phosphate buffered saline containing 2\% FBS and $0.2 \%$ sodium azide) and then incubated with whole rat and mouse IgG (Jackson ImmunoResearch, West Grove, PA) for 30 min on ice to block Fc receptors, followed by a PBSAz wash. The cells were incubated for $30 \mathrm{~min}$ on ice with flourochrome labeled antibodies. The cells were washed several times with PBSAz and fixed overnight at $4^{\circ} \mathrm{C}$ with $0.4 \%$ paraformaldehyde. The paraformaldehyde was removed and cells resuspended in PBSAz. Stained cells were analyzed using a FACSAria and FACSDiva software (BD Biosciences Pharmingen). A total of 10,000 events were collected for each sample.

\section{Cytokine production}

The release of Interleukin-2 (IL-2), Interleukin 4 (IL-4), Interleukin 10 (IL-10), and Interferon-gamma (IFN- $\gamma$ ) in splenocytes at PND14 and PND49 was measured using the Mouse TH1/TH2 Ready-SET-Go! ELISA set (eBioscience). Briefly, $1 \times 10^{6} \mathrm{cells} / \mathrm{ml}$ 
in RPMI media (Mediatech Cellgro; Manassas, VA) supplemented with 10\% FBS were seeded in 48-well plates and stimulated with anti-CD3 (10 $\mu \mathrm{g} / \mathrm{ml}$; eBioscience) and antiCD28 $(10 \mu \mathrm{g} / \mathrm{ml}$; eBioscience). The culture supernatant was collected $24 \mathrm{~h}$ after the stimulation for the assessment of IL-2, and $72 \mathrm{~h}$ after the stimulation for the assessment of IL-4, IL-10, and IFN- $\gamma$. The concentrations of the cytokines were assessed per manufacturer's protocol.

Statistical Analysis

Results are expressed as mean \pm S.E.M. For Figure 1, a mean of the data from 3 mice/litter was taken and used as the $\mathrm{N}=1$ data for the corresponding dam. For Figures 2-4, a mean of the data from 5-8 offspring/sex/treatment group/age group was taken. Statistical analyses comparing the values for a particular cell population or cytokine concentration between Cd-exposed (single dose) and control offspring were performed using the t-test. An alpha value of $\$ 0.05$ was considered significant. All experiments were repeated at least three times. 


\section{RESULTS}

\section{Tissue Cd levels}

The average $\mathrm{Cd}$ concentration for the dams was $4.37 \pm 0.76$ (SEM) $\mu \mathrm{g} / \mathrm{g}$ kidney tissues, which demonstrates a low environmentally relevant exposure level that is consistent between dams. Analysis of Cd levels in the offspring were attempted; however no $\mathrm{Cd}$ was detected in their kidneys, and liver $\mathrm{Cd}$ levels were slightly above the minimum level of detection for the ICP-OES (2.5 ppb) when livers from 3 offspring from Cd-treated dams were pooled. Cd was not detected in the offspring from control dams. This finding demonstrates that the offspring were exposed to $\mathrm{Cd}$; however, transplacental transfer was very low.

\section{Effect of prenatal Cd exposure on thymocyte phenotype in PND14 and 49 offspring}

Thymocyte phenotype of representative offspring from each litter was measured by cell surface marker expression using flow cytometry. Total thymocyte number was not significantly different between Cd-treated and control offspring at PND14 (25.9 \pm 3.4 $\times 10^{7}$ vs. $23.0 \pm 3.0 \times 10^{7}$, respectively) or at PND49 $\left(25.4 \pm 2.2 \times 10^{7}\right.$ vs. $21.2 \pm 1.8 \times 10^{7}$, respectively). At PND14, the number of DN cells was significantly increased in Cdtreated offspring compared to the control offspring $\left[1.95 \pm 0.28 \times 10^{7}\right.$ vs. $1.34 \pm 0.20 \times 10^{7}$ $(p<0.05)$, respectively] (Figure $1 \mathrm{~A})$. The significant increase in the DN population persisted until PND49 [Cd-treated offspring, 2.29 $\pm 0.21 \times 10^{7}$ DN cells vs. control offspring, $1.80 \pm 0.12 \times 10^{7} \mathrm{DN}$ cells $\left.(p<0.05)\right]$. No other population of thymocytes was significantly altered at either day of analysis. Analysis of subpopulations of the DN population at PND14 showed that Cd-treated offspring had significantly more DN1 cells 
$\left(4.86 \pm 0.97 \times 10^{6}\right)$ compared to control offspring $\left(2.80 \pm 0.41 \times 10^{6}\right)(p<0.05)$ (Figure 1B). The increase in DN1 cell number among Cd-treated offspring was still present at PND49 [Cd-treated, 9.93 $\pm 0.90 \times 10^{6}$ vs. control, $\left.7.72 \pm 0.53 \times 10^{6}(\mathrm{p}<0.05)\right]$. The DN2 cell numbers also showed an increasing trend in Cd-treated offspring at PND14 and 49, though the difference was not significant $(p<0.06)$. There were no sex-specific effects on thymocyte phenotype observed in PND14 or PND49 offspring.

Effect of prenatal Cd exposure on splenocyte phenotype in PND14 and 49 offspring

Splenocyte phenotype of representative offspring from each litter was determined by flow cytometry using cell markers specific for CD4 and CD8 T cells, B cells, macrophages, and granulocytes. Total splenocyte number was not significantly different between Cd-treated and control offspring $\left(1.1 \pm 0.8 \times 10^{8}\right.$ vs. $1.0 \pm 0.93 \times 10^{8}$, respectively). The only cell type that showed a significant difference between the $\mathrm{Cd}$ treated offspring and control animals was macrophage (Figure 2). Further, this difference only occurred in male offspring. At PND14, Cd-treated males had 0.78 \pm 0.27 $\times 10^{7}$ macrophages while control offspring had $1.47 \pm 0.14 \times 10^{7}(p<0.05)$ macrophages (Figure 2A). The significant decrease in Cd-treated males was still present at PND49 [(Cd-treated, $1.35 \pm 0.22 \times 10^{7}$ vs. control, 2.25 $\left.\pm 0.27 \times 10^{7}(p<0.05)\right]$ (Figure 2B). All other cell populations had no significant differences between the two treatment groups. 
Effect of prenatal Cd exposure on spleen cell ex vivo cytokine production at PND14 and 49

In order to determine the effects of prenatal $\mathrm{Cd}$ exposure on the immune response of offspring at PND14 and 49, production of IL-2, IL-4, IL-10, and IFN- $\gamma$ by splenic $\mathrm{T}$ cells was measured following stimulation with anti-CD3/28. At PND14, Cdtreated females produced significantly less IL-2 than control females [Cd-treated, $2.31 \pm 0.77 \mu \mathrm{g} / \mathrm{ml}$ vs. control, $7.40 \pm 1.41 \mu \mathrm{g} / \mathrm{ml}(\mathrm{p}<0.01)$ ] (Figure 3). IL-4 production was also significantly decreased in Cd-treated females compared to control females [Cdtreated, $202.42 \pm 7.15 \mathrm{pg} / \mathrm{ml}$ vs. control, $299.76 \pm 17.86 \mathrm{pg} / \mathrm{ml}(\mathrm{p}<0.05)]$ (Figure 3). Cdtreated male offspring did not demonstrate any statistically significant difference in cytokine production at PND14, although IFN- $\gamma$ was markedly decreased in Cd-treated male offspring $(p<0.06)$. At PND49, IL-2 production remained significantly decreased in Cd-treated females compared to control females [Cd-treated, $3.36 \pm 1.02 \mu \mathrm{g} / \mathrm{ml}$ vs. control, $8.21 \pm 1.22 \mu \mathrm{g} / \mathrm{ml}(p<0.05)]$ (Figure 4). IFN- $\gamma$ was significantly decreased in both Cd-treated males (Cd treated, $0.47 \pm 0.10 \mu \mathrm{g} / \mathrm{ml}$ vs. control, $12.52 \pm 2.48 \mu \mathrm{g} / \mathrm{ml}$ ) and females (Cd-treated, $3.69 \pm 0.98 \mu \mathrm{g} / \mathrm{ml}$ vs. control, $9.29 \pm 2.54 \mu \mathrm{g} / \mathrm{ml}$ ) compared to control animals $(p<0.05)$ (Figure 4). There were no differences in IL-10 or IL-4 production in either Cd-treated males or females at PND49. In addition, the cytokines Interleukin12 p70 (IL-12p70), Tumor Necrosis Factor- $\alpha$ (TNF- $\alpha$ ), Monocyte Chemoattractant Protein-1 (MCP-1), and Interleukin-6 (IL-6) were measured but none of these cytokines showed any difference between the Cd-treated offspring and the controls (data not shown). Taken together, cytokine production by prenatally Cd-treated female offspring is affected at an earlier developmental stage than their male counterparts. In female 
offspring at PND49, the data suggest that the Th1 cells (IL-2 and IFN- $\gamma$ producing) are affected, while the Th2 cells (IL-10 and IL-4 producing) are not. In the male offspring at the same time point, there was no effect on the IL-2, IL-4, or IL-10 production, yet IFN- $\gamma$ was significantly decreased. 
Figure 1
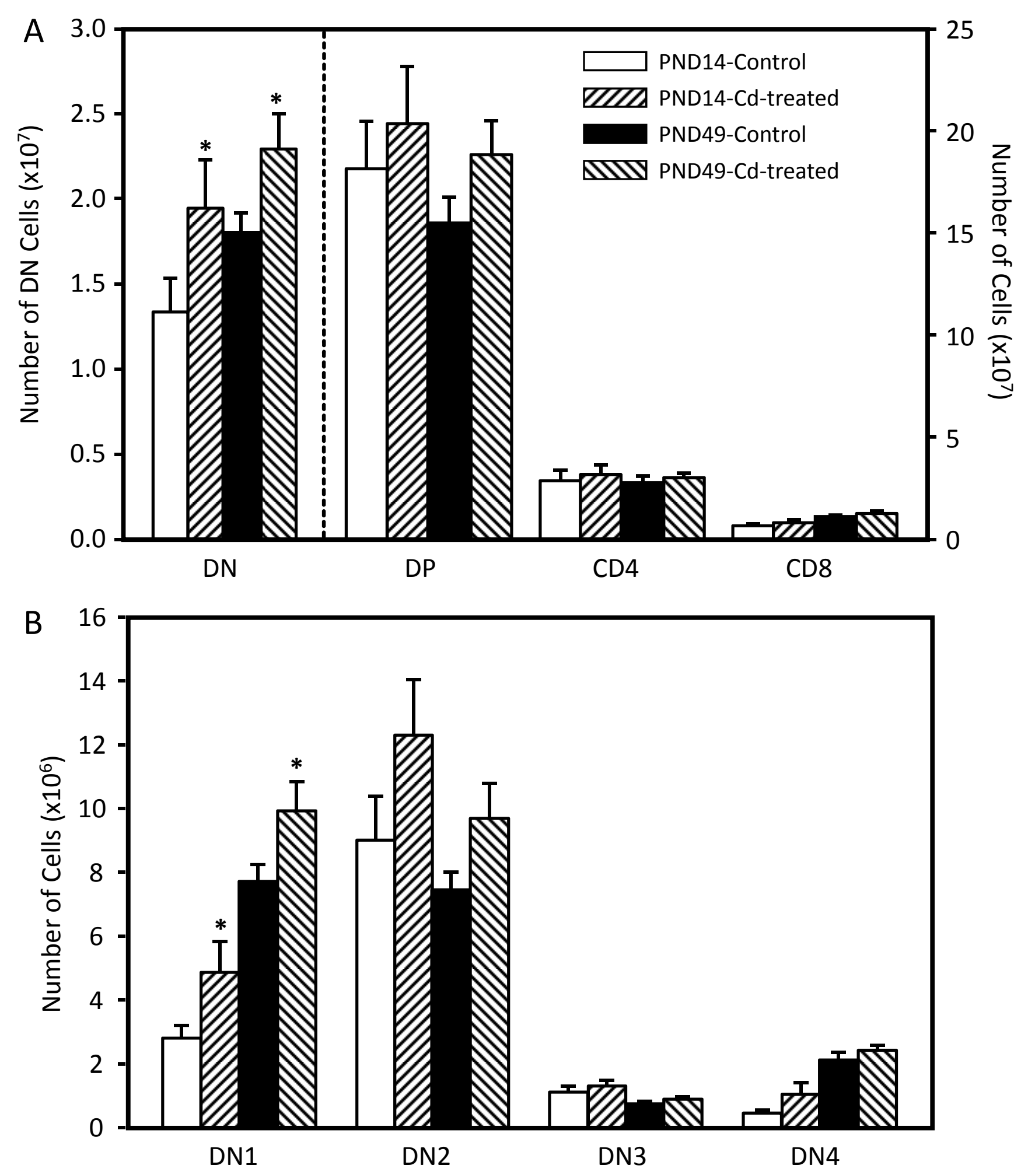
Figure 1. Thymocyte phenotype of PND14 and 49 offspring. Thymocytes were isolated from 14 and 49 day old mice that were exposed to $10 \mathrm{ppm} \mathrm{Cd}$ in utero. Single cell suspensions were prepared for flow cytometry analysis by standard methods. Each bar represents the mean \pm SEM. Data are representative of 3 experiments where $N=4$ in each group (A) Thymocyte phenotype was determined based on CD4 and CD8 cell surface expression. (B) DN subpopulation phenotype was determined based on CD44 and CD25 cell surface expression. ${ }^{*} p<0.05$ 
Figure 2

A

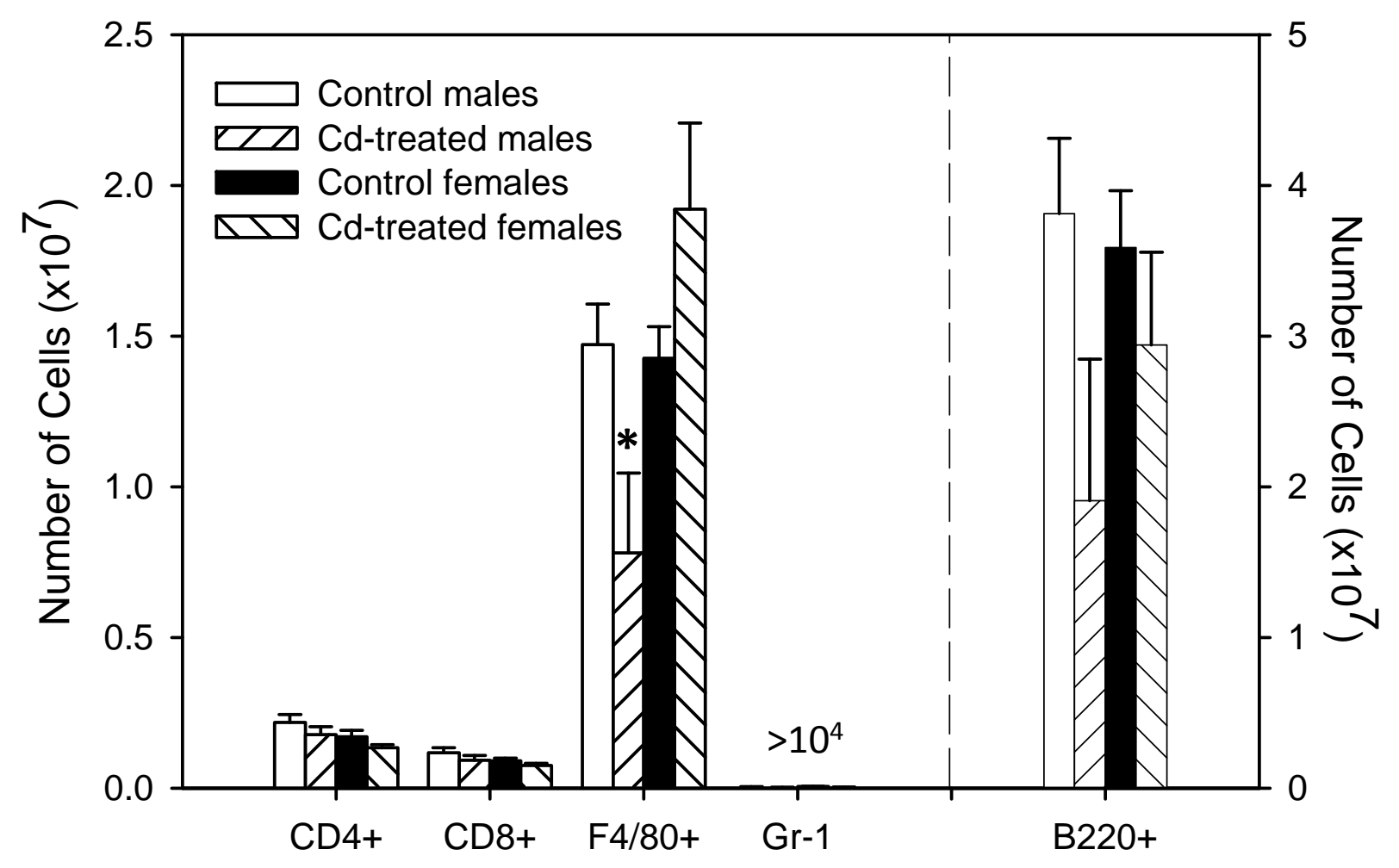

B

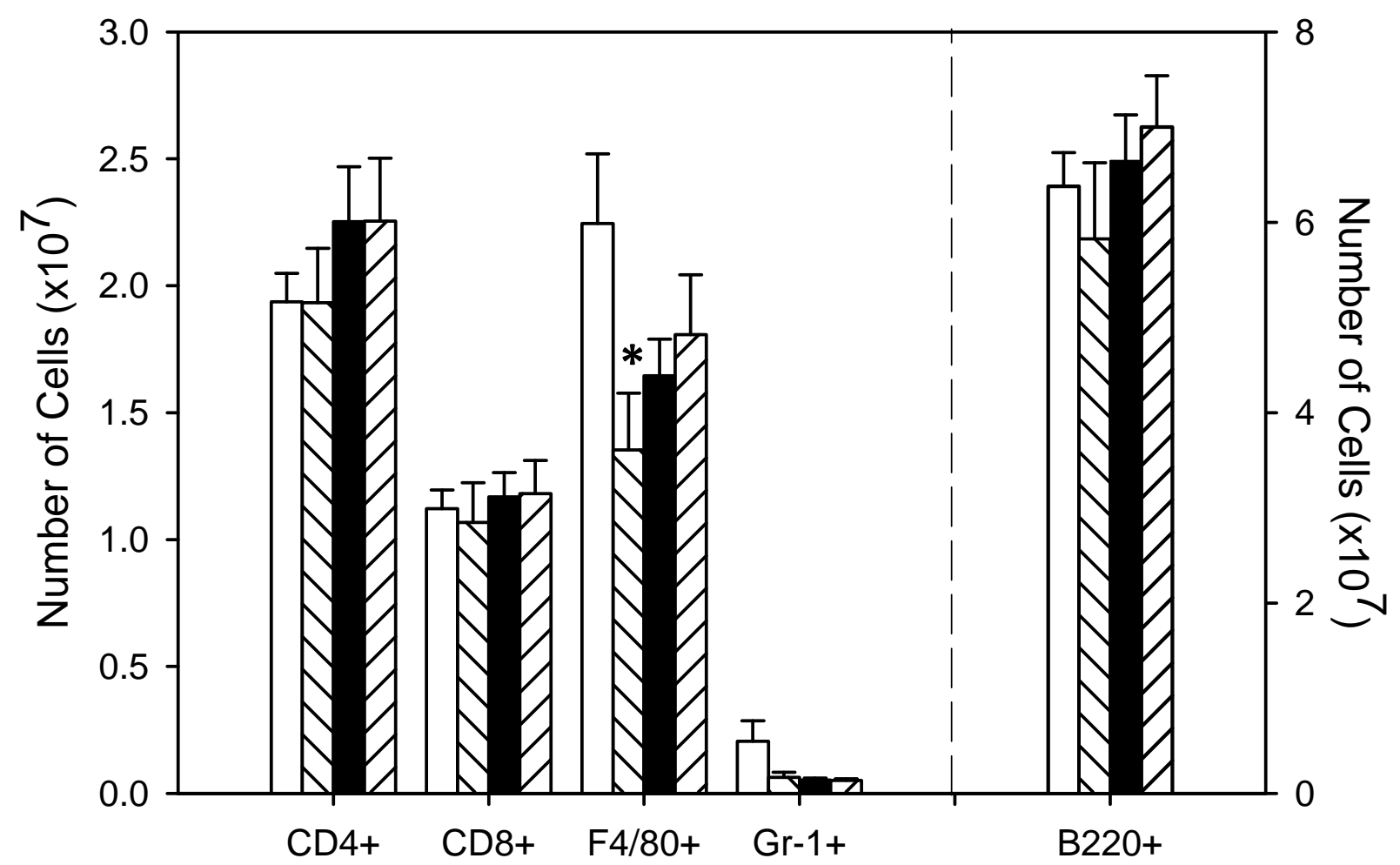


Figure 2. Splenocyte phenotype of PND14 and 49 offspring. Spleen cells were isolated from $14(\mathrm{~A})$ and 49 (B) day old mice that were exposed to $10 \mathrm{ppm} \mathrm{Cd}$ in utero. Single cell suspensions were prepared for flow cytometry analysis by standard methods. Flow cytometric analysis was performed by staining splenocytes with antiCD4, anti-CD8, anti-B220 (B cells), anti-F4/80 (macrophages), and anti-Gr-1 (granulocytes). Each bar represents the mean \pm SEM. Data are representative of 3 experiments where $\mathrm{N}=5-8$ offspring/sex/treatment group/age group. ${ }^{*} \mathrm{p}<0.01$ 
Figure 3

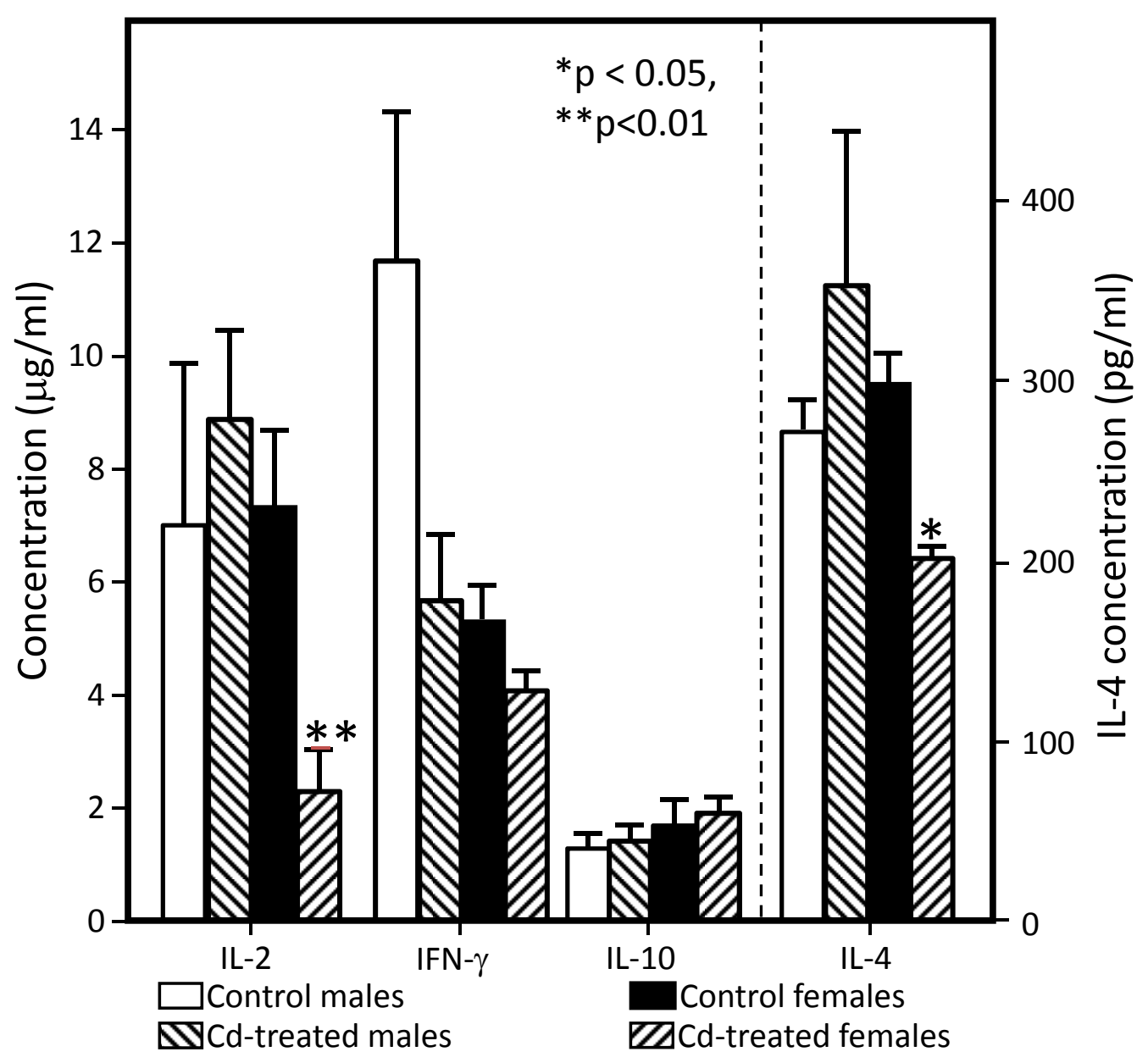


Figure 3. Cytokine expression of splenic T cells on PND14. Spleen cells were isolated from 14 day old mice that were exposed to $10 \mathrm{ppm} \mathrm{Cd}$ in utero. Cells were stimulated with anti-CD3/CD28 for $24 \mathrm{~h}$ (IL-2) or $72 \mathrm{~h}$ (IFN- $\gamma$, IL-10 and IL-4). Supernatants were analyzed for cytokine expression by ELISA kits. Limit of detection: IL-2 (2 pg/ml), IFN- $\gamma,(15 \mathrm{pg} / \mathrm{ml}), \mathrm{IL}-10(30 \mathrm{pg} / \mathrm{ml}), \mathrm{IL}-4(4 \mathrm{pg} / \mathrm{ml})$. Each bar represents the mean \pm SEM. Data are representative of 3 experiments where $N=5-8$ offspring/sex/treatment group. ${ }^{*} \mathrm{p}<0.05,{ }^{* \star} \mathrm{p}<0.01$ 
Figure 4

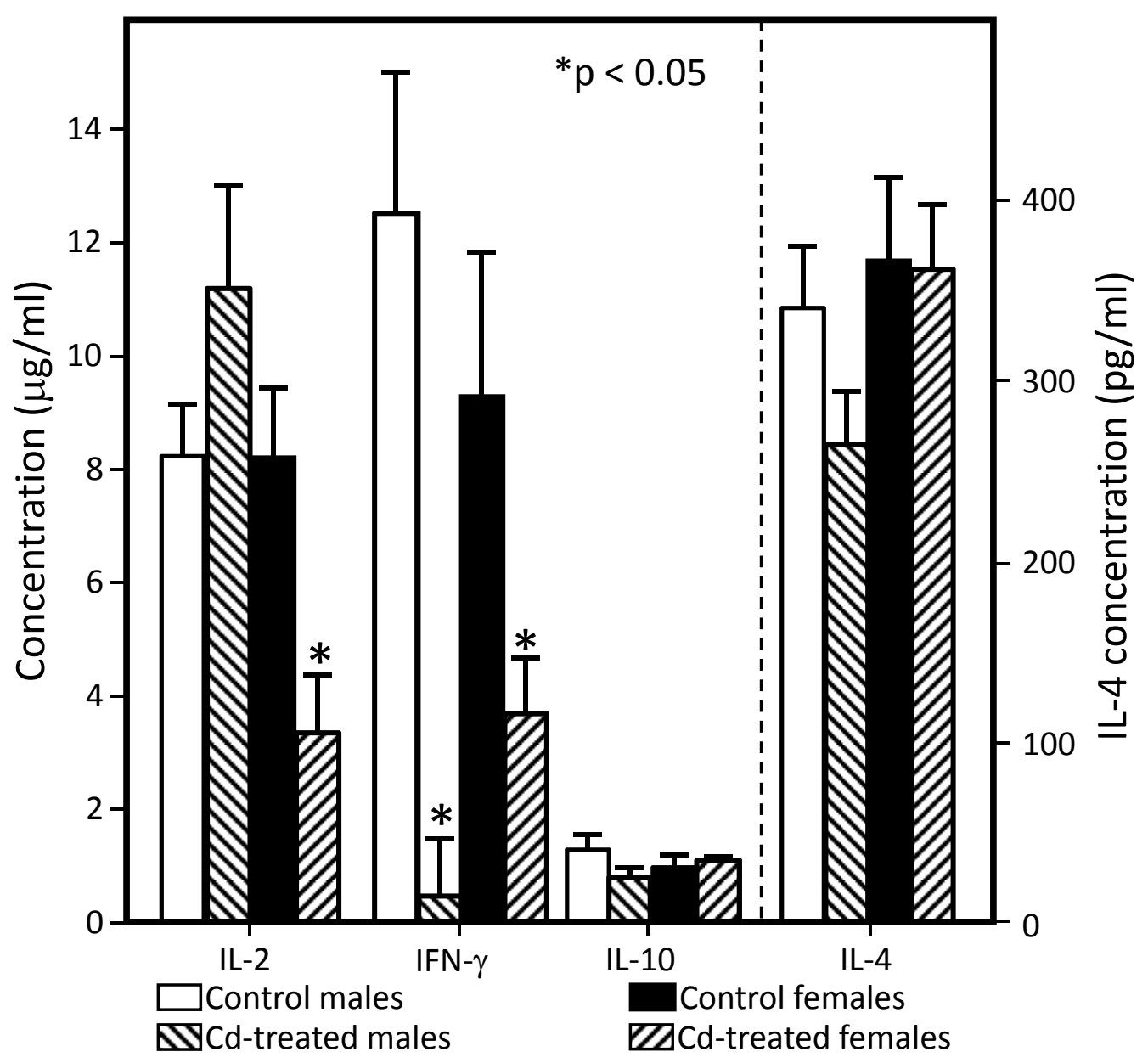


Figure 4. Cytokine expression of splenic T cells on PND49. Spleen cells were isolated from 49 day old mice that were exposed to $10 \mathrm{ppm} \mathrm{Cd}$ in utero. Cells were stimulated with anti-CD3/CD28 for $24 \mathrm{~h}$ (IL-2) or $72 \mathrm{~h}$ (IFN- $\gamma$, IL-10 and IL-4). Supernatants were analyzed for cytokine expression by ELISA kits. Limit of detection: IL-2 (2 pg/ml), IFN- $\gamma,(15 \mathrm{pg} / \mathrm{ml}), \mathrm{IL}-10(30 \mathrm{pg} / \mathrm{ml}), \mathrm{IL}-4(4 \mathrm{pg} / \mathrm{ml})$. Each bar represents the mean \pm SEM. Data are representative of 3 experiments where $N=5-8$ offspring/sex/treatment group. ${ }^{*} p<0.05$ 


\section{DISCUSSION}

Immunotoxicity after $\mathrm{Cd}$ exposure in adult animals is well documented; however, reports concerning the effect of $\mathrm{Cd}$ exposure during gestation on the immune system are limited. We have previously demonstrated that prenatal $\mathrm{Cd}$ exposure alters thymocyte development in offspring at PND0 (Hanson et al, unpublished), while another study showed that proliferative responses of spleen cells to mitogens and activity of peritoneal macrophages were increased, and delayed type hypersensitivity to sheep red blood cells after immunization was decreased, in prenatal Cd-exposed offspring (Soukupova et al., 1991). Due to organogenesis of the immune system occurring mostly at the prenatal, and to a lesser extent, at the early postnatal stage, the perinatal period is not only more sensitive to deleterious effects of immunotoxicants, but alterations in the immune system can result in persistent effects (Holladay and Smialowicz, 2000). Exposure to toxic agents such as halogenated aromatic hydrocarbons (HAHs), polycyclic aromatic hydrocarbons (PAHs), hormonal substances, and heavy metals during the developmental period can result in a range of functional defects in adulthood, including suppression of the immune system (Blaylock et al., 1992; Keil et al., 2008), hypersensitivity (Miller et al., 1998), and autoimmune disease (Snyder et al., 2000; Mustafa et al., 2008). In vitro studies have demonstrated that Cd causes oxidative stress and apoptosis in adult mouse T- and B-cells (Pathak and Khandelwal, 2006b; Pathak and Khandelwal, 2006a), as well as macrophages (Kim and Sharma, 2006). The thymus is an important primary lymphoid organ where successive stages of cell development and selection produce functionally competent $T$ cells from 
immature precursor cells. Several in vivo studies demonstrated that adult exposure to Cd is able to cause significant weight decrease or atrophy of the thymus in mice using a wide range of doses (Borgman et al., 1986; Mackova et al., 1996; Liu et al., 1999). In addition, in vitro studies have demonstrated that exposure to Cd results in apoptosis and phenotypic changes in thymocytes from adult mice (Dong et al., 2001; Pathak and Khandelwal, 2007a). The present analysis of offspring thymocyte phenotype following prenatal Cd exposure demonstrates an increase in the DN population, which is in agreement with previous reports of Dong (2001) and Pathak (2007a). Examination of the four DN subpopulations demonstrates that the earliest stage in thymocyte development, DN1, was significantly increased after prenatal $\mathrm{Cd}$ exposure at both PND14 and 49. We have previously shown a link between prenatal $\mathrm{Cd}$ exposure and dysregulation of the sonic hedgehog (Shh) and Wnt/ $/$-catenin signaling pathways in the thymus at PND0 (Hanson et al, unpublished). Both of these pathways are needed for differentiation of DN1 cells to DN2 cells, therefore a continued perturbation of these pathways at PND14 and 49 may be responsible for the altered thymocyte phenotype.

In vitro and in vivo studies in adult mice have shown that splenocytes are more sensitive to Cd treatment than are thymocytes (Pathak and Khandelwal, 2006b; Pathak and Khandelwal, 2006a; Pathak and Khandelwal, 2007b). Although we did not observe a significant decrease in the total number of splenocytes in prenatally Cd-treated offspring, an analysis of splenocyte phenotype demonstrated that the macrophage population was decreased in Cd-treated offspring. More strikingly, this effect was only present in male offspring. In vivo studies by others indicate that chronic $\mathrm{Cd}$ exposure alters the redox balance in adult male mice, inducing changes in lipid metabolism in 
macrophages, ultimately leading to apoptosis (Ramirez and Gimenez, 2002). In addition to being antigen presenting cells and phagocytes, macrophages can recognize tumor cells and induce cell death by releasing cytotoxic factors such as reactive oxygen and/or nitrogen intermediates, as well as cytokines; thus, the decrease in macrophage number in prenatal Cd-treated male offspring may increase susceptibility of males to tumor incidence. Further studies will have to be conducted to understand the mechanism of this cell type-, sex-specific effect.

Since cytokines influence or control most immune responses, cytokine production by splenic $\mathrm{T}$ cells of offspring following prenatal $\mathrm{Cd}$ exposure was determined. In vitro studies have suggested that Th1 type cytokines (IL-2, IFN- $\gamma$ ) are depressed to a higher degree than Th2 type cytokines (IL-10, IL-4) following Cd treatment (Krocova et al., 2000; Hemdan et al., 2006; Pathak and Khandelwal, 2007a). Studies demonstrating that a decrease in Shh signaling in peripheral $\mathrm{CD}^{+} \mathrm{T}$ cells down-regulates the synthesis of IL-2 and IFN- $\gamma$ (Stewart et al., 2002) and that prenatal Cd exposure decreases Shh signaling in the thymus of offspring at PNDO (Hanson et al, unpublished), led to the hypothesis that Th1 cells in the spleen would be more sensitive to prenatal Cd exposure than Th2 cells. Analysis at PND14 demonstrated that cytokine production (IL-2 and IL-4) was only decreased in females. Analysis at PND49 revealed a dramatic Th1 type (IL-2 and IFN- $\gamma$ ) cytokine decrease by T cells from female offspring, as well as a decrease in IFN- $\gamma$ secretion by $\mathrm{T}$ cells from male offspring. The IL-4 levels at PND14 reached comparable levels to control females by PND49, thus this cytokine may be affected in early development but returns to normal levels as the immune system reaches maturity. Mouse studies evaluating sex differences following $\mathrm{Cd}$ 
exposure are sparse. In humans, although no studies have been designed to investigate sex differences directly, related studies have shown that Cd-associated health effects are more frequent among women than men (Vahter et al., 2002). This may be due to a higher $\mathrm{Cd}$ body burden in women, reflected as higher Cd levels in blood, urine, and kidney cortex (Vahter et al., 2007). The main reason for the higher body burden in women is increased intestinal absorption of dietary $\mathrm{Cd}$ at low iron stores (Akesson et al., 2002; Kippler et al., 2007). Cd and iron compete with one another for transport into the mucosa cell via the divalent metal transporter 1 (DMT-1). When a woman is pregnant, enterocytes have an increased DMT-1 density at the apical surface to increase absorption of micronutrients, thus $\mathrm{Cd}$ absorption is increased during pregnancy (Akesson et al., 2002; Vahter et al., 2007). It has been reported that $90 \%$ of patients with Itai-Itai disease, the most severe form of chronic $\mathrm{Cd}$ intoxication in humans, were postmenopausal women (Jarup et al., 1998). This is due to Cd's ability to disrupt calcium homeostasis caused by estrogen depletion during menopause or following ovariectomy (Jarup et al., 1998). Another reason for sex-differences in susceptibility to Cd-induced toxicity may be attributed to Cd having estrogenic effects (Garcia-Morales et al., 1994; Stoica et al., 2000; Sogawa et al., 2001; Choe et al., 2003; Johnson et al., 2003). Following in utero exposure to $\mathrm{Cd}$, female offspring experienced an earlier onset of puberty and an increase in the epithelial area and the number of terminal end buds in the mammary gland (Johnson et al., 2003). In addition, in vivo studies using adult female rats suggest that females may be at a greater risk than males for Cd-induced immunomodulation due to interactions between estrogen and Cd (Pillet et al., 2006). Pathak and Khandelwal (Pathak and Khandelwal, 2007a) demonstrated 
that IFN- $\gamma$ is inhibited at a lower Cd concentration than IL-2 in adult male mice, so if female offspring have a higher body burden or are more sensitive to prenatal $\mathrm{Cd}$ treatment, then a higher dose of $\mathrm{Cd}$ may be necessary to elicit a decrease in IL-2 in male offspring, thus explaining the lack of effect on IL-2 production, but decreased IFN- $\gamma$ production in male offspring in the present study.

The immunomodulatory effects of prenatal Cd exposure observed in this study may provide insight as to why children of women who smoke during pregnancy have an increased risk for developing cancer later in life. Several studies have indicated that smoking while pregnant increases the risk of certain types of childhood cancers, such as leukemias, lymphomas, and central nervous system tumors, in the prenatally exposed offspring (Filippini et al., 1994; Filippini et al., 2000; Schuz et al., 2001; Brooks et al., 2004). In the U.S., more than a million newborns are exposed to cigarette smoke during gestation (DHHS, 2000). A single cigarette typically contains 1-2 $\mu \mathrm{g}$ of $\mathrm{Cd}$. When burned, Cd is present at a level of $1,000-3,000 \mathrm{ppb}$ in the smoke (ATSDR, 1999). Approximately 40 to $60 \%$ of the $\mathrm{Cd}$ inhaled from cigarette smoke is able to pass through the lungs and into the body (Sahmoun et al., 2005). This means that for each pack of cigarettes smoked, a person can absorb an additional 1-3 $\mu \mathrm{g}$ of $\mathrm{Cd}$ in addition to the amount taken in from other sources in one's daily life. Assuming that adult mice drink approximately $3 \mathrm{ml}$ of water/day, the concentration of $\mathrm{Cd}$ being ingested by mice in the present experiment is nearly equivalent to the concentration of $\mathrm{Cd}$ that would be inhaled from smoking 1 pack of cigarettes/day. A study in which pregnant mice were exposed to a low concentration of mainstream cigarette smoke throughout gestation increased the incidence and growth rate of EL-4 induced tumors in male offspring, as well as 
reduced cytotoxic $T$ lymphocyte activity in male offspring at 5 and 10 weeks after birth ( $\mathrm{Ng}$ et al., 2006). $\mathrm{Ng}$ et al. (2006) findings support epidemiologic data indicating that children of mothers who smoke during pregnancy have a greater risk of developing cancer later in life. The decreased macrophage number, as well as decreased IFN- $\gamma$ production in male offspring in the present study may explain the increased susceptibility to tumor incidence and growth in male offspring exposed to cigarette smoke in utero.

In summary, we have demonstrated that prenatal exposure to environmentally relevant $\mathrm{Cd}$ levels causes persistent immunomodulatory effects in murine offspring. Thymocyte phenotype analysis determined that these effects are cell type-specific, whereas analysis of splenocyte phenotype demonstrates a cell type- and sex-specific effect. The cytokine profiles suggest an effect on peripheral Th1 cells in females and to a lesser degree in males. Others have noted different effects in the offspring of animals prenatally exposed to Cd, such as postaxial forelimb ectrodactyly (Scott et al., 2005), and delayed effects on renal function (Jacquillet et al., 2007) and sensorimotor developmental (Minetti and Reale, 2006), but this is the first report of such an effect on immune cell phenotype and function. The decrease in Th1 type cytokine production in females and the decreases in IFN- $\gamma$ production and macrophage cell number in males may lead to increased susceptibility of the offspring to infections and tumor growth. These findings suggest that even very low exposure to $\mathrm{Cd}$ during gestation may result in long term detrimental effects on the immune system of the offspring, possibly resulting in cancer at adulthood, thus reinforcing that exposure to $\mathrm{Cd}$ during pregnancy should be limited. 


\section{ACKNOWLEDGEMENTS}

The authors would like to thank Dr. Janet Tou for analysis of Cd load in tissues. 


\section{REFERENCES}

Agency for Toxic Substances and Disease Registry. (1999). Toxicological Profile for Cadmium. US Department of Human and Health Services.

Akesson, A., Berglund, M., Schutz, A., Bjellerup, P., Bremme, K., and Vahter, M. (2002). Cadmium exposure in pregnancy and lactation in relation to iron status. American journal of public health 92, 284-287.

Blaylock, B. L., Holladay, S. D., Comment, C. E., Heindel, J. J., and Luster, M. I. (1992). Exposure to tetrachlorodibenzo-p-dioxin (TCDD) alters fetal thymocyte maturation. Toxicol Appl Pharmacol 112, 207-213.

Borgman, R. F., Au, B., and Chandra, R. K. (1986). Immunopathology of chronic cadmium administration in mice. Int J Immunopharmacol 8, 813-817.

Brooks, D. R., Mucci, L. A., Hatch, E. E., and Cnattingius, S. (2004). Maternal smoking during pregnancy and risk of brain tumors in the offspring. A prospective study of 1.4 million Swedish births. Cancer Causes Control 15, 997-1005.

Choe, S. Y., Kim, S. J., Kim, H. G., Lee, J. H., Choi, Y., Lee, H., and Kim, Y. (2003). Evaluation of estrogenicity of major heavy metals. The Science of the total environment 312, 15-21.

DHHS (2000). Treating tobacco use and dependence U.S. DHHS, PHS, Rockville, MD.

Dong, S., Shen, H. M., and Ong, C. N. (2001). Cadmium-induced apoptosis and phenotypic changes in mouse thymocytes. Molecular and cellular biochemistry 222, 11-20. 
Filippini, G., Farinotti, M., and Ferrarini, M. (2000). Active and passive smoking during pregnancy and risk of central nervous system tumours in children. Paediatric and perinatal epidemiology 14, 78-84.

Filippini, G., Farinotti, M., Lovicu, G., Maisonneuve, P., and Boyle, P. (1994). Mothers' active and passive smoking during pregnancy and risk of brain tumours in children. International journal of cancer 57, 769-774.

Garcia-Morales, P., Saceda, M., Kenney, N., Kim, N., Salomon, D. S., Gottardis, M. M., Solomon, H. B., Sholler, P. F., Jordan, V. C., and Martin, M. B. (1994). Effect of cadmium on estrogen receptor levels and estrogen-induced responses in human breast cancer cells. The Journal of biological chemistry 269, 16896-16901.

Hemdan, N. Y., Emmrich, F., Sack, U., Wichmann, G., Lehmann, J., Adham, K., and Lehmann, I. (2006). The in vitro immune modulation by cadmium depends on the way of cell activation. Toxicology. .

Holladay, S. D., and Smialowicz, R. J. (2000). Development of the murine and human immune system: differential effects of immunotoxicants depend on time of exposure. Environ Health Perspect 108 Suppl 3, 463-473.

Jacquillet, G., Barbier, O., Rubera, I., Tauc, M., Borderie, A., Namorado, M. C., Martin, D., Sierra, G., Reyes, J. L., Poujeol, P., and Cougnon, M. (2007). Cadmium causes delayed effects on renal function in the offspring of cadmiumcontaminated pregnant female rats. American journal of physiology 293, F14501460. 
Jarup, L., Berglund, M., Elinder, C. G., Nordberg, G., and Vahter, M. (1998). Health effects of cadmium exposure--a review of the literature and a risk estimate. Scandinavian journal of work, environment \& health 24 Suppl 1, 1-51.

Johnson, M. D., Kenney, N., Stoica, A., Hilakivi-Clarke, L., Singh, B., Chepko, G., Clarke, R., Sholler, P. F., Lirio, A. A., Foss, C., Reiter, R., Trock, B., Paik, S., and Martin, M. B. (2003). Cadmium mimics the in vivo effects of estrogen in the uterus and mammary gland. Nature medicine 9, 1081-1084.

Keil, D. E., Mehlmann, T., Butterworth, L., and Peden-Adams, M. M. (2008). Gestational Exposure to Perfluorooctane Sulfonate Suppresses Immune Function in B6C3F1 Mice. Toxicol. Sci. 103, 77-85.

Kim, J., and Sharma, R. P. (2006). Cadmium-induced apoptosis in murine macrophages is antagonized by antioxidants and caspase inhibitors. J Toxicol Environ Health A. $69,1181-1201$.

Kippler, M., Ekstrom, E. C., Lonnerdal, B., Goessler, W., Akesson, A., El Arifeen, S., Persson, L. A., and Vahter, M. (2007). Influence of iron and zinc status on cadmium accumulation in Bangladeshi women. Toxicol Appl Pharmacol 222, 221-226.

Krocova, Z., Macela, A., Kroca, M., and Hernychova, L. (2000). The immunomodulatory effect(s) of lead and cadmium on the cells of immune system in vitro. Toxicol In Vitro. 14, 33-40.

Liu, J., Liu, Y., Habeebu, S. S., and Klaassen, C. D. (1999). Metallothionein-null mice are highly susceptible to the hematotoxic and immunotoxic effects of chronic CdCl2 exposure. Toxicol Appl Pharmacol 159, 98-108. 
Mackova, N. O., Lenikova, S., Fedorocko, P., Brezani, P., and Fedorockova, A. (1996). Effects of cadmium on haemopoiesis in irradiated and non-irradiated mice: 2. Relationship to the number of circulating blood cells and haemopoiesis. Physiological research / Academia Scientiarum Bohemoslovaca 45, 101-106.

Miller, T. E., Golemboski, K. A., Ha, R. S., Bunn, T., Sanders, F. S., and Dietert, R. R. (1998). Developmental exposure to lead causes persistent immunotoxicity in Fischer 344 rats. Toxicol Sci 42, 129-135.

Minetti, A., and Reale, C. A. (2006). Sensorimotor developmental delays and lower anxiety in rats prenatally exposed to cadmium. J Appl Toxicol 26, 35-41.

Mustafa, A., Holladay, S. D., Goff, M., Witonsky, S. G., Kerr, R., Reilly, C. M., Sponenberg, D. P., and Gogal Jr, R. M. (2008). An enhanced postnatal autoimmune profile in 24 week-old C57BL/6 mice developmentally exposed to TCDD. Toxicology and Applied Pharmacology 232, 51-59.

Ng, S. P., Silverstone, A. E., Lai, Z.-W., and Zelikoff, J. T. (2006). Effects of Prenatal Exposure to Cigarette Smoke on Offspring Tumor Susceptibility and Associated Immune Mechanisms. Toxicol. Sci. 89, 135-144.

Pathak, N., and Khandelwal, S. (2006a). Influence of cadmium on murine thymocytes: potentiation of apoptosis and oxidative stress. Toxicol Lett. 165, 121-132.

Pathak, N., and Khandelwal, S. (2006b). Oxidative stress and apoptotic changes in murine splenocytes exposed to cadmium. Toxicology. 220, 26-36.

Pathak, N., and Khandelwal, S. (2007a). Impact of cadmium in T lymphocyte subsets and cytokine expression: differential regulation by oxidative stress and apoptosis. Biometals. 
Pathak, N., and Khandelwal, S. (2007b). Role of oxidative stress and apoptosis in cadmium induced thymic atrophy and splenomegaly in mice. Toxicology Letters.

Pillet, S., D'Elia, M., Bernier, J., Bouquegneau, J. M., Fournier, M., and Cyr, D. G. (2006). Immunomodulatory Effects of Estradiol and Cadmium in Adult Female Rats. Toxicological Sciences 92, 423-432.

Ramirez, D. C., and Gimenez, M. S. (2002). Lipid modification in mouse peritoneal macrophages after chronic cadmium exposure. Toxicology 172, 1-12.

Sahmoun, A. E., Case, L. D., Jackson, S. A., and Schwartz, G. G. (2005). Cadmium and prostate cancer: a critical epidemiologic analysis. Cancer investigation $\mathbf{2 3}$, 256-263.

Schuz, J., Kaletsch, U., Kaatsch, P., Meinert, R., and Michaelis, J. (2001). Risk factors for pediatric tumors of the central nervous system: results from a German population-based case-control study. Medical and pediatric oncology 36, 274282.

Snyder, J. E., Filipov, N. M., Parsons, P. J., and Lawrence, D. A. (2000). The efficiency of maternal transfer of lead and its influence on plasma IgE and splenic cellularity of mice. Toxicol Sci 57, 87-94.

Sogawa, N., Onodera, K., Sogawa, C. A., Mukubo, Y., Fukuoka, H., Oda, N., and Furuta, H. (2001). Bisphenol A enhances cadmium toxicity through estrogen receptor. Methods and findings in experimental and clinical pharmacology 23, 395-399. 
Soukupova, D., Dostal, M., and Piza, J. (1991). Developmental toxicity of cadmium in mice. II. Immunotoxic effects. Functional and developmental morphology 1, 3136.

Stewart, G. A., Lowrey, J. A., Wakelin, S. J., Fitch, P. M., Lindey, S., Dallman, M. J., Lamb, J. R., and Howie, S. E. M. (2002). Sonic Hedgehog Signaling Modulates Activation of and Cytokine Production by Human Peripheral CD4+ T Cells, pp. $5451-5457$.

Stoica, A., Katzenellenbogen, B. S., and Martin, M. B. (2000). Activation of estrogen receptor-alpha by the heavy metal cadmium. Molecular endocrinology (Baltimore, Md 14, 545-553.

Vahter, M., Akesson, A., Liden, C., Ceccatelli, S., and Berglund, M. (2007). Gender differences in the disposition and toxicity of metals. Environmental research 104, 85-95.

Vahter, M., Berglund, M., Akesson, A., and Liden, C. (2002). Metals and women's health. Environmental research 88, 145-155. 
CHAPTER 4: General Discussion I 


\section{GENERAL DISCUSSION I}

The overall objective of this dissertation was to determine the effect of prenatal Cd exposure on the immune system. Specifically, our experiments were designed to investigate the effect of prenatal $\mathrm{Cd}$ exposure on thymocyte development, and to determine if these effects were linked to dysregulation of the Shh and $\mathrm{Wnt} / \beta$-catenin pathways in the thymus. In addition, longer term effects of prenatal $\mathrm{Cd}$ on the immune system were investigated. Studies demonstrating a dysregulation of Shh (Scott et al., 2005) and Wnt/ $\beta$-catenin (Thompson et al., 2008) signaling by prenatal Cd exposure, coupled with the requirement of Shh (Outram et al., 2000) and $W n t / \beta$-catenin (Oosterwegel et al., 1991; Verbeek et al., 1995; Hattori et al., 1996; loannidis et al., 2001) in thymocyte development, led to the overall hypothesis that prenatal Cd exposure dysregulates these signaling pathways in the thymus of the offspring, leading to changes in thymocyte phenotype, ultimately resulting in long term immunomodulatory effects.

It is well established that $\mathrm{Cd}$ exposure in adults results in immunotoxic effects (Descotes, 1992); however, studies on the effect of prenatal Cd exposure on the immune system of offspring are limited (Soukupova et al., 1991). In the U.S., more than a million newborns are exposed to cigarette smoke during gestation (DHHS, 2000). Cigarette smoke contains $1,000-3,000 \mathrm{ppb} \mathrm{Cd}$. Several studies have indicated that smoking while pregnant increases the risk of certain types of childhood cancers, such as leukemias, lymphomas, and central nervous system tumors, in the prenatally exposed offspring (Filippini et al., 1994; Filippini et al., 2000; Schuz et al., 2001; Brooks et al., 2004). To an even greater extent, studies have linked maternal smoking with 
respiratory disease, asthma and/or atopy in the offspring (Hu et al., 1997; Alati et al., 2006; Jaakkola et al., 2006; Pattenden et al., 2006; Raherison et al., 2007), thus it is critical to elucidate Cd's role in these immunomodulatory effects. In this discussion, I will focus on the immunomodulatory effects of prenatal Cd exposure assessed at three developmental stages (PND0, 14, and 49) in murine offspring. In addition, I will describe a mechanism for the observed effects on PND0, and hypothesize possible mechanisms for the cell type-, sex- specific effects observed on PND14 and 49.

The focus of Chapter 2 of this dissertation addressed the effect of prenatal $\mathrm{Cd}$ exposure on thymocyte development in offspring at PND0. We hypothesized that prenatal Cd exposure alters thymocyte development due to a dysregulation in Shh and Wnt/ $\beta$-catenin signaling. In order to understand how we arrived at this hypothesis, a brief review of the data leading up to this is required.

The thymus is a target organ of Cd-induced toxicity. Cd-treatment of adult rats results in damage to the thymus as well as changes to the proliferation rate of thymocytes (Morselt et al., 1988). Several in vivo studies demonstrated that adult exposure to $\mathrm{Cd}$ is able to cause significant weight decrease or atrophy of the thymus in mice using a wide range of doses (Borgman et al., 1986; Mackova et al., 1996; Liu et al., 1999). To our knowledge, there have been no studies that have examined the effect of in vivo Cd exposure on thymocyte phenotype. Studies that have examined the effect of direct in vitro Cd exposure on thymocyte phenotype, however, report a decrease in DP cells (Dong et al., 2001; Pathak and Khandelwal, 2007), an increase in DN cells (Pathak and Khandelwal, 2007), and a decrease in the $\mathrm{CD} 4^{+} / \mathrm{CD} 8^{+}$ratio (Dong et al., 2001; Pathak and Khandelwal, 2007). 
The Hedgehog $(\mathrm{Hh})$ and Wnt family proteins act as morphogens during thymocyte development. Shh signaling, is critical in the development of thymocytes and T-cell activation (Shah et al., 2004). Shh proteins act as regulators at several stages of $\mathrm{T}$-cell development in the thymus. Analysis of Shh" ${ }^{-/}$thymi showed that Shh is necessary for efficient proliferation of DN thymocytes (Shah et al., 2004). One study analyzing Shh's role in the development of SP cells, showed that Shh signaling in developing thymocytes influences TCR repertoire selection and differentiation from DP to SP cells (Rowbotham et al., 2007). Specifically, in $\mathrm{Shh}^{-1-}$ fetal thymic organ cultures, the $\mathrm{CD}^{+} / \mathrm{CD}^{+}$ratio was increased. In addition to $\mathrm{Hh}$ proteins, the Wnt family of glycoproteins is involved in regulating thymocyte maturation (Staal et al., 2001). Wnt proteins are secreted morphogens that are involved in a variety of cell activities in development. Wnt signals are transduced through at least three different signaling pathways; however, the canonical $\beta$-catenin/T-cell factor-lymphoid enhancer factor (TCF-LEF) primarily functions during thymocyte development. Inhibition of the Wnt pathway results in reduced DN proliferation and differentiation, decreased DP survival (Verbeek et al., 1995; Okamura et al., 1998; Schilham et al., 1998), and decreased $\mathrm{CD}^{+}$generation (Mulroy et al., 2003).

Several studies have shown that prenatal Cd exposure dysregulates Shh signaling (Scott et al., 2005; Yu et al., 2006) and adult Cd exposure dyregulates Wnt/ßcatenin signaling (Prozialeck et al., 2003; Thevenod et al., 2007; Thompson et al., 2008). Scott et al. (2005) demonstrated that administration of $\mathrm{CdSO}_{4}$ to $\mathrm{C} 57 \mathrm{BI} / 6$ mice at day 9.5 of gestation induces postaxial forelimb ectrodactyly in the offspring. This development malformation was due to Cd disrupting Shh signaling in the mouse limb 
bud. Although Shh signaling was decreased as measured by Shh-Light 2 cells, Shh transcription and translation was not affected, which led Scott et al. (2005) to propose that prenatal Cd exposure affects the processing of Shh in the cells in which it is made. Yu et al. (2006) quantified in vivo changes in Shh expression during early development in a green fluorescence protein transgenic zebrafish line following $\mathrm{Cd}$ exposure. The study showed that embryos affected by Cd-exposure demonstrated a down-regulation in Shh expression as determined by a decrease in the number of GFP-expressing cells measured by flow cytometry, and a decrease in expression of a downstream target of the Shh signaling pathway.

Prozialeck et al. (2003) demonstrated that Cd exposure in adult male SpragueDawley rats affects cadherin-dependent junctions in the proximal tubule epithelium, resulting in changes in localization of $\beta$-catenin. Thevenod et al. (2007) followed up this study with data proving that $\mathrm{Cd}$ induces nuclear translocation of $\beta$-catenin in proximal tubular cells, using a rat renal proximal tubule cell model. In addition, Thompson et al. (2008) demonstrated that $\mathrm{Cd}$ exposure induced nuclear translocation of $\beta$-catenin in peridermal and ectodermal cells when administered to post-gastrulation chick embryos.

Based on the aforementioned data that demonstrates an effect of adult $\mathrm{Cd}$ exposure on thymocyte development, a requirement of Shh and $\mathrm{Wnt} / \beta$-catenin signaling for proper thymocyte development, and an effect of Cd exposure on Shh and Wnt/ $\beta$ catenin signaling, we proposed to determine the effects of prenatal $\mathrm{Cd}$ exposure on thymocyte development, and to link those effects to a dysregulation in Shh and Wnt/Bcatenin signaling. The data indicated that prenatal $\mathrm{Cd}$ exposure dysregulates two signaling pathways in the thymus, resulting in altered thymocyte development in murine 
offspring at birth. To determine effects on thymocyte development, thymocyte phenotype was analyzed by flow cytometry. We showed that prenatal Cd exposure increased the DN4 subpopulation and the $\mathrm{CD} 4^{+}$cell population. Further, a significant increase in $\mathrm{CD}^{+}$cells and a trended decrease in $\mathrm{CD} 8^{+}$cells resulted in an approximate 10-fold increase in the $\mathrm{CD}^{+} / \mathrm{CD} 8^{+}$ratio. In contrast to our findings, Dong et al. and Pathak and Khandelwal (2007) showed that in vitro Cd exposure decreased the $\mathrm{CD}^{+} / \mathrm{CD} 8^{+}$ratio, however, the relevance of these studies to the interpretation of those reported herein is questionable because of the differences in experimental design such as in vitro vs. in vivo exposure, Cd dose, length of exposure, mouse strain, and developmental stage of the exposed cells. In addition, in vitro exposure would not account for possible effects on the thymic epithelium in addition to the thymocytes, which could have a significant impact on the phenotype. In our study, thymocytes were exposed to an indirect, environmentally relevant concentration of $\mathrm{Cd}$. Although $\mathrm{Cd}$ was detected in pooled livers of the offspring, the level was close to the minimum level of detection, thus we believe that any possible direct $\mathrm{Cd}$ effect is minimal to nil. The increased $\mathrm{CD} 4^{+} / \mathrm{CD} 8^{+}$ratio observed in our study could have several consequences in cell-mediated immunity and T-cell host response to infection in the offspring, including an increased chance of developing autoimmune disease and allergies, as well as an increased susceptibility to viruses and tumor cells.

To determine the mechanism for altered thymocyte development by prenatal $\mathrm{Cd}$ exposure, we analyzed several components of the Shh and Wnt/ $\beta$-catenin pathways. Using the Gli:luciferase reporter cell line, Shh-Light 2, we observed an approximate $24 \%$ decrease in Shh signaling in the Shh-producing TECs, although this was not due 
to a decrease in Shh or Gli1 protein levels. A decrease in mRNA level of Shh target gene Wnt10b in TECs further demonstrated a decrease in Shh signaling. Analysis of Shh target genes, Ptc1 and Gli1 in Shh-receiving thymocytes, showed that prenatal Cd exposure increased expression of Shh target genes, Gli1 and Ptc1, in DN and CD8 ${ }^{+}$ thymocytes, despite decreased Shh signaling in TECs. Based on our data and findings of others that suggest cells near the source of Shh secretion can modulate the range of the signal by upregulating their expression of Ptc, which can sequester Shh and thereby prevent it from spreading further (Chen and Struhl, 1996), we hypothesized that in an environment where Shh signaling is decreased, $\mathrm{DN}$ and $\mathrm{CD}^{+}$cells may upregulate Ptc1 in order to sequester the limited signal, and this would contribute to the upregulation of Gli1 transcription. Analysis of thymocyte phenotype showed a significant increase in the DN4 cell population as well as a trended increase in the DN3 cell population, thus, increased Shh signaling in the DN population may contribute to increased proliferation of these DN subpopulations. The role that Shh signaling plays in single positive cells has not been well defined, however, one study showed that Shh signaling in developing thymocytes influences TCR repertoire selection and differentiation from DP to SP cells (Rowbotham et al., 2007). Specifically, in Shh" ${ }^{-/}$fetal thymic organ cultures, the $\mathrm{CD} 4^{+} / \mathrm{CD} 8^{+}$ratio was increased, therefore, the decreased Shh signal from TECs in the present study is likely contributing to the increased $\mathrm{CD}^{+} / \mathrm{CD} 8^{+}$ratio observed in prenatal Cd-treated offspring. In addition, the increased transcription of Ptc1 and Gli1 in $\mathrm{CD}^{+}$and no change in these genes in $\mathrm{CD} 4^{+}$cells may also contribute to the significantly increased $\mathrm{CD} 4^{+} / \mathrm{CD} 8^{+}$ratio observed in thymocyte phenotype analysis. 
Our data also showed that $\mathrm{Wnt} / \beta$-catenin signaling was decreased in thymocytes as determined by an increase in phospho- $\beta$-catenin in the cytoplasm and a decrease in $A B C$ in the nucleus; however, this decrease was not due to a decrease in Wnt10b protein level in the TECs. Analysis of Wnt/ $\beta$-catenin target genes, $c$-fos, $c$-jun, and $c$ myc, showed that mRNA levels were affected differentially among thymocyte populations. There was an overall upregulation of these genes in all of the thymocyte populations except the $\mathrm{CD}^{+}$population. Interestingly, thymocyte phenotype analysis showed that this was the only population that had a trended decrease following prenatal Cd exposure. Although $c$-fos, $c-j u n$, and $c$-myc are known $W n t / \beta$-catenin target genes, it is unlikely that their upregulation is due to an increase in $A B C$ levels since prenatal $\mathrm{Cd}$ exposure caused a decrease in $A B C$ and an increase in phospho- $\beta$-catenin protein levels in total thymocytes when analyzed. There are many proteins that are involved in $\beta$-catenin regulation, such as the destruction complex in the cytoplasm and inhibitory proteins in the nucleus, therefore one or a combination of those proteins may be affected by prenatal $\mathrm{Cd}$ exposure and contributing to our observed results.

Our data demonstrating the effect of prenatal Cd exposure on Shh and Wnt/Bcatenin signaling implies that prenatal $\mathrm{Cd}$ exposure affects the processing and/or secretion of Shh and Wnt proteins in the thymic epithelium resulting in an attenuated signal in both pathways. In order for Shh and Wnt proteins to inititate proper signaling, they must go through a series of processing steps prior to secretion that involve multiple proteins. Any one of these steps could be a target of $\mathrm{Cd}$, thus, furthur investigation should be conducted in order to elucidate this mechanism. Our results also imply that each thymocyte population responds uniquely to the decreased signals, as 
demonstrated by varying target gene expression. One hypothesis for the altered signaling in thymocytes is that prenatal $\mathrm{Cd}$ is affecting $\mathrm{Zn}$ levels. Studies have shown that detrimental fetal effects have been attributed to $\mathrm{Cd}$ affecting $\mathrm{Zn}$ transportation from dam to fetus by the inhibition of transport proteins, thus decreasing $\mathrm{Zn}$ concentration in the fetal liver and placenta (Sowa and Steibert, 1985; Baranska-Gachowska et al., 1987). However, a study that used the same dose of $\mathrm{Cd}(10 \mathrm{ppm})$, the same strain of mouse (C57BI/6), and the same day of analysis (PND0) as the study in Chapter 2, demonstrated that prenatal $\mathrm{Cd}$ exposure increased the hepatic and renal $\mathrm{Zn}$ concentration in the offspring, suggesting that the $\mathrm{Zn}$ deficiency may not be the only explanation for the effect of prenatal Cd (Ishitobi and Watanabe, 2005). To date, there have been no analyses of thymic $\mathrm{Zn}$ concentration following $\mathrm{Cd}$ exposure at any developmental stage. There is a requirement for $\mathrm{Zn}$ in the Shh (Hall et al., 1995; Koebernick and Pieler, 2002) and Wnt/B-catenin (Chen et al., 2009) pathways, therefore if prenatal $\mathrm{Cd}$ is disrupting $\mathrm{Zn}$ homeostasis in the thymus, it is likely that these pathways would be affected.

Another hypothesis for a mechanism that may contribute to Cd's effect on Shh and $\mathrm{Wnt} / \beta$-catenin signaling, involves activation of cellular protein kinases resulting in enhanced phosphorylation of transcription factors. Kinases activated following exposure of cells to Cd include protein kinase C (Beyersmann et al., 1994; Yu et al., 1997; Watkin et al., 2003), tyrosine kinase and casein kinase II (Saydam et al., 2002), stress activated protein kinase (Ding and Templeton, 2000), and the mitogen activated protein kinase family (LaRochelle et al., 2001). In the Wnt/ $\beta$-catenin pathway, CKI and GSK3 $\beta$ are responsible for phosphorylating $\beta$-catenin, thus targeting it for ubiquitination 
and degradation. Activation of these kinases would explain our findings of increased phospho- $\beta$-catenin in the cytoplasm and decreased active $\beta$-catenin in the nucleus of prenatal Cd-treated offspring. In the Shh pathway, protein kinase $A(P K A)$ is responsible for phosphorylating Gli $2 / 3$, thus targeting them for proteolytic processing to their smaller, repressor form. Activation of PKA would explain our finding of decreased transcription of Shh target gene, Wnt10b, in the thymus of prenatal-Cd treated offspring. Due to the combined complexity of each of the pathways and the reported effects of $\mathrm{Cd}$ on specific components of the pathways, a more global analysis of gene expression in each of the thymocyte populations should be undertaken so that the effect of prenatal Cd exposure on the Shh and Wnt/ $\beta$-catenin pathways can be thoroughly elucidated.

The focus of Chapter 3 of this dissertation addressed the effect of prenatal $\mathrm{Cd}$ exposure on postnatal immune cell development and function. Due to organogenesis of the immune system occurring mostly at the prenatal, and to a lesser extent, at the early postnatal stage, the perinatal period is not only more sensitive to deleterious effects of immunotoxicants, but alterations in the immune system can result in persistent effects (Holladay and Smialowicz, 2000), therefore, we hypothesized that the effects on thymocyte development observed on PND0 would lead to continued effects on thymocyte and splenocyte development, as well as immune cell function at later developmental stages (PND14 and PND49). The data indicated that even a very low level of exposure to Cd during gestation can result in long term detrimental effects on the immune system of the offspring, and these effects are to some extent sex-specific. Prenatal $\mathrm{Cd}$ exposure increased the number of double negative (DN; CD4-CD8) thymocytes, specifically the DN1 subpopulation (CD44 $\left.{ }^{+} \mathrm{CD} 25^{-}\right)$, at PND14 and 49 . This 
finding implies that prenatal $\mathrm{Cd}$ exposure has a continued effect on the thymus of exposed offspring. Due to the low transplacental transfer of Cd (Piasek et al., 2001), it is unlikely that we are observing a continued direct effect of $\mathrm{Cd}$, thus we consider the effect to be immunoteratogenic. Analysis of splenocyte phenotype showed that prenatal Cd exposure decreased the number of macrophages, albeit only in males at PND14 and 49. This finding suggests that prenatal Cd exposure exerts a cell-type-, sexspecific effect in the spleen of exposed offspring. Moreover, this is a persistent effect. In vivo studies by others indicate that chronic $\mathrm{Cd}$ exposure alters the redox balance in adult male mice, inducing changes in lipid metabolism in macrophages, ultimately leading to apoptosis (Ramirez and Gimenez, 2002). In addition to being antigen presenting cells and phagocytes, macrophages can recognize tumor cells and induce cell death by releasing cytotoxic factors such as reactive oxygen and/or nitrogen intermediates, as well as cytokines; thus, the decrease in macrophage number in prenatal Cd-treated male offspring may increase susceptibility of males to tumor incidence. An analysis of macrophage function in male offspring should be conducted as well as additional studies to understand the mechanism of this cell type-, sex-specific effect.

Data on cytokine production on PND14 demonstrated that cytokine production (IL-2 and IL-4) was only decreased in females. Analysis at PND49 showed a dramatic Th1 type (IL-2 and IFN- $\gamma$ ) cytokine decrease by T cells from female offspring, as well as a decrease in IFN- $\gamma$ secretion by T cells from male offspring. The IL-4 levels at PND14 reached comparable levels to control females by PND49, thus this cytokine may be affected in early development but returns to normal levels as the immune system 
reaches maturity. In vitro studies have suggested that Th1 type cytokines (IL-2, IFN- $\gamma$ ) are depressed to a higher degree than Th2 type cytokines (IL-10, IL-4) following Cd treatment (Krocova et al., 2000; Hemdan et al., 2006; Pathak and Khandelwal, 2007), thus, our findings are to some extent, in support of the in vitro findings. Mouse studies evaluating sex differences following Cd exposure are limited; however, in vivo studies using adult female rats suggest that females may be at a greater risk than males for $\mathrm{Cd}$ induced immunomodulation due to interactions between estrogen and Cd (Pillet et al., 2006). In addition, a finding that demonstrated Cd having a hierarchical effect on cytokine production in males may explain why males had decreased IFN- $\gamma$ production but IL-2 was not affected. Pathak and Khandelwal (2007) demonstrated that IFN- $\gamma$ is inhibited at a lower Cd concentration than IL-2 in adult male mice, so if female offspring in our study have a higher body burden or are more sensitive to prenatal Cd treatment, then a higher dose of $\mathrm{Cd}$ may be necessary to elicit a decrease in IL-2 in male offspring. Based on the data detailed in Chapters 2 and 3 of this dissertation, and data demonstrating addition of neutralizing anti-Shh antibody to anti-CD3/CD28 stimulated $\mathrm{CD}^{+} \mathrm{T}$ cell cultures reduced IL-2 and IFN- $\gamma$ production, but not IL-10 production (Stewart et al., 2002), we hypothesize that the changes in splenic T cell cytokine production are linked to changes in morphogen signaling.

Since cytokines influence or control most immune responses, the decrease in Th1 cytokines caused by prenatal $\mathrm{Cd}$ exposure may increase the offspring's susceptibility to bacterial and viral infections. Adult $\mathrm{Cd}$ exposure has also been shown to decrease host resistance in mice caused by viruses [murine coxsakie B3 virus (Ilback et al., 1995; Glynn et al., 1998) and the enterovirus, encephalomyocarditis (Gainer, 
1977)], bacteria [E.coli (Cook et al., 1975), Listeria monocytogenes (Simonyte et al., 2003) and Mycobacterium bovis (Bozelka and Burkholder, 1979)], and parasites [Hexamita muris (Exon et al., 1975)]. The decrease in Th1 type cytokine production in females and the decreases in IFN- $\gamma$ production and macrophage cell number in males, in our study, may lead to increased susceptibility of the offspring to infections and tumor growth, therefore; examination of host resistance in offspring exposed prenatally to $\mathrm{Cd}$ will be an important area of analysis.

In summary, data presented in this dissertation indicate that prenatal $\mathrm{Cd}$ exposure dysregulates two morphogen pathways required for proper thymocyte development, resulting in altered thymocyte phenotype in offspring on PND0. Further, modifications in thymocyte phenotype remained present in offspring at the adult stage, in addition to changes in spleen cell phenotype and function. These findings suggest that the defect caused by prenatal $\mathrm{Cd}$ exposure may be permanently encoded into the offspring and extends to secondary lymphoid organs. Therefore, even very low exposure to $\mathrm{Cd}$ during gestation may result in long term detrimental effects on the immune system of the offspring, possibly resulting in susceptibility to infections and disease at adulthood, thus reinforcing that exposure to Cd during pregnancy should be limited. The findings detailed in this dissertation are novel in that they are the first to: 1) demonstrate that prenatal exposure to $\mathrm{Cd}$ affects thymocyte development throughout post-natal development; 2) show that prenatal Cd dysregulates Wnt/ $\beta$-catenin signaling in a mouse model, and 3) observe a sex-specific effect on immune cell phenotype and function following prenatal $\mathrm{Cd}$ exposure. The data presented herein provide a mechanism for prenatal Cd's effect on thymocyte development in offspring observed on 
PND0. This mechanism may be applicable to other detrimental effects of prenatal Cd exposure. In addition to the thymus, $\mathrm{Hh}$ and $\mathrm{Wnt} / \beta$-catenin signaling is necessary for proper development of the kidney (Stark et al., 1994; Kang et al., 1997), bone (Gao et al., 2001; Gong et al., 2001; Loughlin et al., 2004), lung (Pepicelli et al., 1998; Tebar et al., 2001; Mucenski et al., 2003; Okubo and Hogan, 2004), and prostate (Podlasek et al., 1999; Truica et al., 2000; Lamm et al., 2002; Mulholland et al., 2002; Chesire and Isaacs, 2003; Freestone et al., 2003; Berman et al., 2004), all of which are target organs of $\mathrm{Cd}$ toxicity (Bernard, 2008). Due to $\mathrm{Hh}$ and $\mathrm{Wnt} / \beta$-catenin signaling being highly conserved among organ systems, it is plausible that prenatal $\mathrm{Cd}$ exposure disrupts these pathways in other organs, resulting in developmental malformations, increased cell proliferation, and possibly cancer. 


\section{REFERENCES}

Alati, R., Al Mamun, A., O'Callaghan, M., Najman, J. M., and Williams, G. M. (2006). In utero and postnatal maternal smoking and asthma in adolescence. Epidemiology (Cambridge, Mass 17, 138-144.

Baranska-Gachowska, M., Soja, J., Postek, L., and Owczarczak, K. (1987). [The effect of environment polluted with non-iron metals on the salivary content of zinc, cadmium and lead in school children in the region of Miasteczko Slaskie]. Czas. Stomatol. 40, 89-93.

Berman, D. M., Desai, N., Wang, X., Karhadkar, S. S., Reynon, M., Abate-Shen, C., Beachy, P. A., and Shen, M. M. (2004). Roles for Hedgehog signaling in androgen production and prostate ductal morphogenesis. Developmental biology 267, 387-398.

Bernard, A. (2008). Cadmium \& its adverse effects on human health. The Indian journal of medical research $128,557-564$.

Beyersmann, D., Block, C., and Malviya, A. N. (1994). Effects of cadmium on nuclear protein kinase C. Environ Health Perspect 102 Suppl 3, 177-180.

Borgman, R. F., Au, B., and Chandra, R. K. (1986). Immunopathology of chronic cadmium administration in mice. Int J Immunopharmacol 8, 813-817.

Bozelka, B. E., and Burkholder, P. M. (1979). Increased mortality of cadmiumintoxicated mice infected with the BCG strain of Mycobacterium bovis. Journal of the Reticuloendothelial Society 26, 229-237. 
Brooks, D. R., Mucci, L. A., Hatch, E. E., and Cnattingius, S. (2004). Maternal smoking during pregnancy and risk of brain tumors in the offspring. A prospective study of 1.4 million Swedish births. Cancer Causes Control 15, 997-1005.

Chen, T., Li, M., Ding, Y., Zhang, L.-S., Xi, Y., Pan, W.-j., Tao, D.-I., Wang, J.-y., and Li, L. (2009). Identification of Zinc-finger BED Domain-containing 3 (Zbed3) as a Novel Axin-interacting Protein That Activates Wnt/\{beta\}-Catenin Signaling. J. Biol. Chem. 284, 6683-6689.

Chen, Y., and Struhl, G. (1996). Dual Roles for Patched in Sequestering and Transducing Hedgehog. Cell 87, 553-563.

Chesire, D. R., and Isaacs, W. B. (2003). Beta-catenin signaling in prostate cancer: an early perspective. Endocrine-related cancer 10, 537-560.

Cook, J. A., Hoffmann, E. O., and Luzio, N. D. (1975). Influence of lead and cadmium on the susceptibility of rats to bacterial challenge. Proceedings of the Society for Experimental Biology and Medicine. Society for Experimental Biology and Medicine (New York, N.Y 150, 741-747.

Descotes, J. (1992). Immunotoxicology of cadmium. IARC Sci Publ., 385-390.

DHHS (2000). Treating tobacco use and dependence U.S. DHHS, PHS, Rockville, MD.

Ding, W., and Templeton, D. M. (2000). Activation of parallel mitogen-activated protein kinase cascades and induction of c-fos by cadmium. Toxicol Appl Pharmacol 162, 93-99.

Dong, S., Shen, H. M., and Ong, C. N. (2001). Cadmium-induced apoptosis and phenotypic changes in mouse thymocytes. Molecular and cellular biochemistry 222, 11-20. 
Exon, J. H., Patton, N. M., and Koller, L. D. (1975). Hexamitiasis in cadmium-exposed mice. Archives of environmental health 30, 463-464.

Filippini, G., Farinotti, M., and Ferrarini, M. (2000). Active and passive smoking during pregnancy and risk of central nervous system tumours in children. Paediatric and perinatal epidemiology $14,78-84$.

Filippini, G., Farinotti, M., Lovicu, G., Maisonneuve, P., and Boyle, P. (1994). Mothers' active and passive smoking during pregnancy and risk of brain tumours in children. International journal of cancer 57, 769-774.

Freestone, S. H., Marker, P., Grace, O. C., Tomlinson, D. C., Cunha, G. R., Harnden, P., and Thomson, A. A. (2003). Sonic hedgehog regulates prostatic growth and epithelial differentiation. Developmental biology 264, 352-362.

Gainer, J. H. (1977). Effects of heavy metals and of deficiency of zinc on mortality rates in mice infected with encephalomyocarditis virus. American journal of veterinary research 38, 869-872.

Gao, B., Guo, J., She, C., Shu, A., Yang, M., Tan, Z., Yang, X., Guo, S., Feng, G., and He, L. (2001). Mutations in IHH, encoding Indian hedgehog, cause brachydactyly type A-1. Nature genetics 28, 386-388.

Glynn, A. W., Lind, Y., Funseth, E., and Ilback, N. G. (1998). The intestinal absorption of cadmium increases during a common viral infection (coxsackie virus B3) in mice. Chemico-biological interactions 113, 79-89.

Gong, Y., Slee, R. B., Fukai, N., Rawadi, G., Roman-Roman, S., Reginato, A. M., Wang, H., Cundy, T., Glorieux, F. H., Lev, D., Zacharin, M., Oexle, K., Marcelino, J., Suwairi, W., Heeger, S., Sabatakos, G., Apte, S., Adkins, W. N., Allgrove, J., 
Arslan-Kirchner, M., Batch, J. A., Beighton, P., Black, G. C., Boles, R. G., Boon, L. M., Borrone, C., Brunner, H. G., Carle, G. F., Dallapiccola, B., De Paepe, A., Floege, B., Halfhide, M. L., Hall, B., Hennekam, R. C., Hirose, T., Jans, A., Juppner, H., Kim, C. A., Keppler-Noreuil, K., Kohlschuetter, A., LaCombe, D., Lambert, M., Lemyre, E., Letteboer, T., Peltonen, L., Ramesar, R. S., Romanengo, M., Somer, H., Steichen-Gersdorf, E., Steinmann, B., Sullivan, B., Superti-Furga, A., Swoboda, W., van den Boogaard, M. J., Van Hul, W., Vikkula, M., Votruba, M., Zabel, B., Garcia, T., Baron, R., Olsen, B. R., and Warman, M. L. (2001). LDL receptor-related protein 5 (LRP5) affects bone accrual and eye development. Cell 107, 513-523.

Hall, T. M., Porter, J. A., Beachy, P. A., and Leahy, D. J. (1995). A potential catalytic site revealed by the 1.7-A crystal structure of the amino-terminal signalling domain of Sonic hedgehog. Nature 378, 212-216.

Hattori, N., Kawamoto, H., Fujimoto, S., Kuno, K., and Katsura, Y. (1996). Involvement of transcription factors TCF-1 and GATA-3 in the initiation of the earliest step of T cell development in the thymus. The Journal of experimental medicine 184, $1137-1147$.

Hemdan, N. Y., Emmrich, F., Sack, U., Wichmann, G., Lehmann, J., Adham, K., and Lehmann, I. (2006). The in vitro immune modulation by cadmium depends on the way of cell activation. Toxicology. .

Holladay, S. D., and Smialowicz, R. J. (2000). Development of the murine and human immune system: differential effects of immunotoxicants depend on time of exposure. Environ Health Perspect 108 Suppl 3, 463-473. 
Hu, F. B., Persky, V., Flay, B. R., Zelli, A., Cooksey, J., and Richardson, J. (1997). Prevalence of asthma and wheezing in public schoolchildren: association with maternal smoking during pregnancy. Ann Allergy Asthma Immunol 79, 80-84.

llback, N. G., Lindh, U., Fohlman, J., and Friman, G. (1995). New aspects of murine coxsackie B3 myocarditis--focus on heavy metals. European heart journal 16 Suppl 0, 20-24.

loannidis, V., Beermann, F., Clevers, H., and Held, W. (2001). The beta-catenin--TCF-1 pathway ensures CD4(+)CD8(+) thymocyte survival. Nature immunology 2, 691697.

Ishitobi, H., and Watanabe, C. (2005). Effects of low-dose perinatal cadmium exposure on tissue zinc and copper concentrations in neonatal mice and on the reproductive development of female offspring. Toxicol Lett. 159, 38-46.

Jaakkola, J. J., Kosheleva, A. A., Katsnelson, B. A., Kuzmin, S. V., Privalova, L. I., and Spengler, J. D. (2006). Prenatal and postnatal tobacco smoke exposure and respiratory health in Russian children. Respiratory research 7, 48.

Kang, S., Graham, J. M., Jr., Olney, A. H., and Biesecker, L. G. (1997). GLI3 frameshift mutations cause autosomal dominant Pallister-Hall syndrome. Nature genetics 15, 266-268.

Koebernick, K., and Pieler, T. (2002). Gli-type zinc finger proteins as bipotential transducers of Hedgehog signaling. Differentiation; research in biological diversity 70, 69-76. 
Krocova, Z., Macela, A., Kroca, M., and Hernychova, L. (2000). The immunomodulatory effect(s) of lead and cadmium on the cells of immune system in vitro. Toxicol In Vitro. 14, 33-40.

Lamm, M. L., Catbagan, W. S., Laciak, R. J., Barnett, D. H., Hebner, C. M., Gaffield, W., Walterhouse, D., lannaccone, P., and Bushman, W. (2002). Sonic hedgehog activates mesenchymal Gli1 expression during prostate ductal bud formation. Developmental biology 249, 349-366.

LaRochelle, O., Gagne, V., Charron, J., Soh, J. W., and Seguin, C. (2001). Phosphorylation is involved in the activation of metal-regulatory transcription factor 1 in response to metal ions. The Journal of biological chemistry $\mathbf{2 7 6}$, $41879-41888$.

Liu, J., Liu, Y., Habeebu, S. S., and Klaassen, C. D. (1999). Metallothionein-null mice are highly susceptible to the hematotoxic and immunotoxic effects of chronic CdCl2 exposure. Toxicol Appl Pharmacol 159, 98-108.

Loughlin, J., Dowling, B., Chapman, K., Marcelline, L., Mustafa, Z., Southam, L., Ferreira, A., Ciesielski, C., Carson, D. A., and Corr, M. (2004). Functional variants within the secreted frizzled-related protein 3 gene are associated with hip osteoarthritis in females. Proceedings of the National Academy of Sciences of the United States of America 101, 9757-9762.

Mackova, N. O., Lenikova, S., Fedorocko, P., Brezani, P., and Fedorockova, A. (1996). Effects of cadmium on haemopoiesis in irradiated and non-irradiated mice: 2. Relationship to the number of circulating blood cells and haemopoiesis. Physiological research / Academia Scientiarum Bohemoslovaca 45, 101-106. 
Morselt, A. F. W., Leene, W., DeGroot, C., Kipp, J. B. A., Evers, M., Roelofsen, A. M., and Bosch, K. S. (1988). Differences in immunological susceptibility to cadmium toxicity between two rat strains as demonstrated with cell biological methods. Effect of cadmium on DNA synthesis of thymus lymphocytes. Toxicology 48, 127139.

Mucenski, M. L., Wert, S. E., Nation, J. M., Loudy, D. E., Huelsken, J., Birchmeier, W., Morrisey, E. E., and Whitsett, J. A. (2003). beta-Catenin is required for specification of proximal/distal cell fate during lung morphogenesis. The Journal of biological chemistry 278, 40231-40238.

Mulholland, D. J., Cheng, H., Reid, K., Rennie, P. S., and Nelson, C. C. (2002). The androgen receptor can promote beta-catenin nuclear translocation independently of adenomatous polyposis coli. The Journal of biological chemistry 277, 1793317943.

Mulroy, T., Xu, Y., and Sen, J. M. (2003). beta-Catenin expression enhances generation of mature thymocytes. International immunology 15, 1485-1494.

Okamura, R. M., Sigvardsson, M., Galceran, J., Verbeek, S., Clevers, H., and Grosschedl, R. (1998). Redundant regulation of $T$ cell differentiation and TCRalpha gene expression by the transcription factors LEF-1 and TCF-1. Immunity 8, 11-20.

Okubo, T., and Hogan, B. L. (2004). Hyperactive Wnt signaling changes the developmental potential of embryonic lung endoderm. Journal of biology 3, 11 .

Oosterwegel, M., van de Wetering, M., Dooijes, D., Klomp, L., Winoto, A., Georgopoulos, K., Meijlink, F., and Clevers, H. (1991). Cloning of murine TCF-1, 
a $\mathrm{T}$ cell-specific transcription factor interacting with functional motifs in the CD3epsilon and $\mathrm{T}$ cell receptor alpha enhancers. The Journal of experimental medicine 173, 1133-1142.

Outram, S. V., Varas, A., Pepicelli, C. V., and Crompton, T. (2000). Hedgehog signaling regulates differentiation from double-negative to double-positive thymocyte. Immunity. 13, 187-197.

Pathak, N., and Khandelwal, S. (2007). Impact of cadmium in T lymphocyte subsets and cytokine expression: differential regulation by oxidative stress and apoptosis. Biometals.

Pattenden, S., Antova, T., Neuberger, M., Nikiforov, B., De Sario, M., Grize, L., Heinrich, J., Hruba, F., Janssen, N., Luttmann-Gibson, H., Privalova, L., Rudnai, P., Splichalova, A., Zlotkowska, R., and Fletcher, T. (2006). Parental smoking and children's respiratory health: independent effects of prenatal and postnatal exposure. Tobacco control 15, 294-301.

Pepicelli, C. V., Lewis, P. M., and McMahon, A. P. (1998). Sonic hedgehog regulates branching morphogenesis in the mammalian lung. Curr Biol 8, 1083-1086.

Piasek, M., Blanusa, M., Kostial, K., and Laskey, J. W. (2001). Placental cadmium and progesterone concentrations in cigarette smokers. Reproductive toxicology (Elmsford, N.Y 15, 673-681.

Pillet, S., D'Elia, M., Bernier, J., Bouquegneau, J. M., Fournier, M., and Cyr, D. G. (2006). Immunomodulatory Effects of Estradiol and Cadmium in Adult Female Rats. Toxicological Sciences 92, 423-432. 
Podlasek, C. A., Barnett, D. H., Clemens, J. Q., Bak, P. M., and Bushman, W. (1999). Prostate development requires Sonic hedgehog expressed by the urogenital sinus epithelium. Developmental biology 209, 28-39.

Prozialeck, W. C., Lamar, P. C., and Lynch, S. M. (2003). Cadmium alters the localization of $\mathrm{N}$-cadherin, E-cadherin, and [beta]-catenin in the proximal tubule epithelium. Toxicology and Applied Pharmacology 189, 180-195.

Raherison, C., Penard-Morand, C., Moreau, D., Caillaud, D., Charpin, D., Kopfersmitt, C., Lavaud, F., Taytard, A., and Annesi-maesano, I. (2007). In utero and childhood exposure to parental tobacco smoke, and allergies in schoolchildren. Respiratory medicine 101, 107-117.

Ramirez, D. C., and Gimenez, M. S. (2002). Lipid modification in mouse peritoneal macrophages after chronic cadmium exposure. Toxicology 172, 1-12.

Rowbotham, N. J., Hager-Theodorides, A. L., Cebecauer, M., Shah, D. K., Drakopoulou, E., Dyson, J., Outram, S. V., and Crompton, T. (2007). Activation of the Hedgehog signaling pathway in T-lineage cells inhibits TCR repertoire selection in the thymus and peripheral T-cell activation, pp. 3757-3766.

Saydam, N., Adams, T. K., Steiner, F., Schaffner, W., and Freedman, J. H. (2002). Regulation of metallothionein transcription by the metal-responsive transcription factor MTF-1: identification of signal transduction cascades that control metalinducible transcription. The Journal of biological chemistry 277, 20438-20445.

Schilham, M. W., Wilson, A., Moerer, P., Benaissa-Trouw, B. J., Cumano, A., and Clevers, H. C. (1998). Critical involvement of Tcf-1 in expansion of thymocytes. J Immunol 161, 3984-3991. 
Schuz, J., Kaletsch, U., Kaatsch, P., Meinert, R., and Michaelis, J. (2001). Risk factors for pediatric tumors of the central nervous system: results from a German population-based case-control study. Medical and pediatric oncology 36, 274282.

Scott, W. J., Jr., Schreiner, C. M., Goetz, J. A., Robbins, D., and Bell, S. M. (2005). Cadmium-induced postaxial forelimb ectrodactyly: association with altered sonic hedgehog signaling. Reproductive toxicology (Elmsford, N.Y 19, 479-485.

Shah, D. K., Hager-Theodorides, A. L., Outram, S. V., Ross, S. E., Varas, A., and Crompton, T. (2004). Reduced thymocyte development in sonic hedgehog knockout embryos. J Immunol 172, 2296-2306.

Simonyte, S., Cerkasin, G., Planciuniene, R., Naginiene, R., Ryselis, S., and Ivanov, L. (2003). Influence of cadmium and zinc on the mice resistance to Listeria monocytogenes infection. Medicina (Kaunas, Lithuania) 39, 767-772.

Soukupova, D., Dostal, M., and Piza, J. (1991). Developmental toxicity of cadmium in mice. II. Immunotoxic effects. Funct.Dev.Morphol. 1, 31-36.

Sowa, B., and Steibert, E. (1985). Effect of oral cadmium administration to female rats during pregnancy on zinc, copper, and iron content in placenta, foetal liver, kidney, intestine, and brain. Archives of toxicology 56, 256-262.

Staal, F. J., Meeldijk, J., Moerer, P., Jay, P., van de Weerdt, B. C., Vainio, S., Nolan, G. P., and Clevers, H. (2001). Wnt signaling is required for thymocyte development and activates Tcf-1 mediated transcription. European journal of immunology $\mathbf{3 1}$, 285-293. 
Stark, K., Vainio, S., Vassileva, G., and McMahon, A. P. (1994). Epithelial transformation of metanephric mesenchyme in the developing kidney regulated by Wnt-4. Nature $372,679-683$.

Stewart, G. A., Lowrey, J. A., Wakelin, S. J., Fitch, P. M., Lindey, S., Dallman, M. J., Lamb, J. R., and Howie, S. E. M. (2002). Sonic Hedgehog Signaling Modulates Activation of and Cytokine Production by Human Peripheral CD4+ T Cells. J Immunol 169, 5451-5457.

Tebar, M., Destree, O., de Vree, W. J., and Ten Have-Opbroek, A. A. (2001). Expression of Tcf/Lef and sFrp and localization of beta-catenin in the developing mouse lung. Mechanisms of development 109, 437-440.

Thevenod, F., Wolff, N. A., Bork, U., Lee, W. K., and Abouhamed, M. (2007). Cadmium induces nuclear translocation of beta-catenin and increases expression of c-myc and Abcb1a in kidney proximal tubule cells. Biometals 20, 807-820.

Thompson, J., Wong, L., Lau, P. S., and Bannigan, J. (2008). Adherens junction breakdown in the periderm following cadmium administration in the chick embryo: distribution of cadherins and associated molecules. Reproductive toxicology (Elmsford, N.Y 25, 39-46.

Truica, C. I., Byers, S., and Gelmann, E. P. (2000). Beta-catenin affects androgen receptor transcriptional activity and ligand specificity. Cancer research 60, 47094713.

Verbeek, S., Izon, D., Hofhuis, F., Robanus-Maandag, E., te Riele, H., van de Wetering, M., Oosterwegel, M., Wilson, A., MacDonald, H. R., and Clevers, H. (1995). An 
HMG-box-containing T-cell factor required for thymocyte differentiation. Nature 374, 70-74.

Watkin, R. D., Nawrot, T., Potts, R. J., and Hart, B. A. (2003). Mechanisms regulating the cadmium-mediated suppression of Sp1 transcription factor activity in alveolar epithelial cells. Toxicology 184, 157-178.

Yu, C. W., Chen, J. H., and Lin, L. Y. (1997). Metal-induced metallothionein gene expression can be inactivated by protein kinase $C$ inhibitor. FEBS letters 420 , 6973.

Yu, R. M., Lin, C. C., Chan, P. K., Chow, E. S., Murphy, M. B., Chan, B. P., Muller, F., Strahle, U., and Cheng, S. H. (2006). Four-dimensional imaging and quantification of gene expression in early developing zebrafish (Danio rerio) embryos. Toxicol Sci. 90, 529-538. 
APPENDIX: Subcellular localization of DCPA 


\section{LITERATURE REVIEW II}

Propanil, or 3, 4-dichloropropionanilide (DCPA), is a post-emergent herbicide used predominately for weed control in rice and wheat production (Dahchour et al., 1986). In 2001, an estimate by the Environmental Protection Agency (EPA) ranked DCPA as the $17^{\text {th }}$ most used pesticide in the U.S., as a result of $50-70 \%$ of all rice grown in the U.S. being treated with the chemical. DCPA is used mostly in southern states along the Mississippi River and in some areas of California. The half-life of DCPA in the environment is 1-3 days in soil and 2-3 days in water (Wauchope et al., 1992). Due to the short half-life and limited use of the herbicide, the majority of exposed individuals are applicators and residents living near treated fields.

Rice and wheat crops have high levels of acylamidase activity, thus they are resistant to DCPA's herbicidal effects due to their ability to enzymatically detoxify the chemical, while weeds lacking this enzyme are killed (Still and Kuzirian, 1967; Matsunaka, 1968). In humans and animals, the most common routes of exposure are inhalation, orbital, dermal, and to a lesser degree, oral. Following absorption, DCPA is metabolized by acylamidase into the major metabolite 3,4-dichloroaniline (DCA) (Williams, 1966). Other metabolites of DCPA include 2'hydroxypropanil and 6'hydroxypropanil (McMillan et al., 1990). DCA is then metabolized to 6-hydroxy-3, 4dichloroaniline and N-hydroxy-3, 4-dichloroaniline. As a result of DCPA being readily metabolized, detection of DCPA in the blood of rats was detectable for approximately 48 hours following exposure (Izmerov, 1984).

Studies have demonstrated that DCPA is not mutagenic (McMillan et al., 1988), carcinogenic (EPA, 2003), or toxic to reproduction (Ambrose et al., 1972). Toxicity to 
factory workers exposed to DCPA during its production and packaging has been reported (Morse et al., 1979). Symptoms of toxicity include blurred vision, small pupils, chloracne, muscle weakness, fatigue, and increased salivation (Morse et al., 1979). Animals studies have shown that manifestations of acute propanil toxicity include central nervous system depression (Singleton and Murphy, 1973), methemaglobinemia (Singleton and Murphy, 1973), and liver damage (Santillo et al., 1995).

DCPA has been extensively described as an immunotoxicant on both primary and secondary immune organs. Two studies have demonstrated DCPA's myelotoxicity (Blyler et al., 1994; Malerba et al., 2002). Following exposure to $200 \mathrm{mg} / \mathrm{kg}$ DCPA, myeloid stem cells were reduced as analyzed using ex vivo colony-forming assays from bone marrow of acutely exposed C57BI/6 mice (Blyler et al., 1994). Effects on early erythroid stem cells observed following in vitro exposure of human umbilical cord to DCPA supported the earlier report of myelotoxicity (Malerba et al., 2002). Erythroid colony-forming units (CFU-E) and erythroid burst-forming units (BFU-E) had $50 \%$ of their growth inhibited by 234 and $441 \mu \mathrm{M}$ DCPA, respectively (Malerba et al., 2002). Several studies have indicated that the thymus is a target of DCPA's toxicity (Barnett and Gandy, 1989; Cuff et al., 1996). In acutely exposed mice, thymic atrophy is observed approximately 2-4 days following exposure (Cuff et al., 1996). This atrophy has been attributed to increased levels of glucocorticoids (Cuff et al., 1996; de la Rosa et al., 2005). Following an intraperitoneal (i.p.) dose of $200 \mathrm{mg} / \mathrm{kg}$, a reduction in thymic weight is present until 7 days following exposure (Barnett and Gandy, 1989), at which time the thymus has begun recovery from the atrophy (Cuff et al., 1996). The thymus reaches full recovery after 14 days following exposure (Cuff et al., 1996). In addition, in 
vivo exposure to $200 \mathrm{mg} / \mathrm{kg}$ i.p. DCPA results in increased spleen weight (Barnett and Gandy, 1989).

Both innate and adaptive immunities are affected by DCPA exposure. The innate immune system is comprised of cell types including monocytes, macrophages, polymorphonuclear monocytes (PMN), and natural killer cells (NK), which serve as the first line of defense against invading pathogens. Studies have demonstrated that DCPA affects NK cells (Barnett et al., 1992; Pruett et al., 2000) and macrophages (Xie et al., 1997; Ustyugova et al., 2007) resulting in suppressed function of both cell types. DCPA also affects macrophage cytokine production. Thioglycollate-elicited macrophages from mice exposed in vivo by oral gavage to $400 \mathrm{mg} / \mathrm{kg}$, or exposed in vitro to $33.3 \mu \mathrm{M}$ DCPA had significantly decreased IL-6 and TNF- $\alpha$ production in response to LPS timulation (Xie et al., 1997). Further, in vitro phagocytosis of Listeria monocytogenes bacteria by macrophages is decreased by DCPA exposure (Frost et al., 2001).

The adaptive immune system is comprised of B lymphocytes (B-cells) and $T$ lymphocytes (T-cells). The primary function of B-cells is to produce and secrete antibodies. $\mathrm{CD}^{+} \mathrm{T}$ cells are responsible for activating and regulating cell-mediated immune responses and the humoral immune response, while $\mathrm{CD}^{+} \mathrm{T}$ cells destroy infected or transformed cells, thus they are called cytotoxic T lymphocytes (CTLs). Analysis of $B$ cells in the periphery following DCPA exposure showed that although DCPA does not affect the number of B cells (Salazar et al., 2005), it does suppress some B cell functions (Barnett and Gandy, 1989; Barnett et al., 1992). In vivo exposure to $400 \mathrm{mg} / \mathrm{kg}$ DCPA suppresses splenic B cell proliferation following ex vivo stimulation with the B cell mitogen LPS (Barnett and Gandy, 1989). Analysis of antibody response 
to T-dependent (TD) and T-independent type 2 (TI-2) model antigens showed that DCPA affects these responses to a greater degree than B cell proliferation (Barnett and Gandy, 1989; Barnett et al., 1992). DCPA has been demonstrated to decrease the TD antibody response to sheep red blood cells (SRBC) and the TI response to DNP-Ficoll (Barnett et al., 1992).

Studies have demonstrated that DCPA exposure results in an overall decrease in T cell number at several developmental stages (Zhao et al., 1995). Following exposure to $100 \mathrm{mg} / \mathrm{kg} \mathrm{DCPA}$, the number of all $\mathrm{CD}^{+}\left(\mathrm{CD}^{+}, \mathrm{CD}^{+}, \mathrm{DP}\right)$ and $\mathrm{CD}^{-}(\mathrm{DN}) \mathrm{T}$ cell populations in the thymus were decreased (Zhao et al., 1995), with the DP population being the most sensitive (Cuff et al., 1996). By day 7 after exposure, the percentage of cycling thymocyte populations returns to normal, suggesting that recovery from DCPA's effect begins soon after exposure (Cuff et al., 1996). T cell function is differentially affected by DCPA. CTL function (Barnett et al., 1992) and cell mediated immune response to Listeria monocytogenes (Watson et al., 2000) were not affected by DCPA exposure. However, splenic $\mathrm{T}$ cell cytokine production of IFN- $\gamma$, granulocytemacrophage colony-stimulating factor (GM-CSF), IL-2, and IL-6 were decreased in a dose-dependent manner following in vivo and in vitro exposure to DCPA and subsequent in vitro stimulation with concanavalin A (Zhao et al., 1998). DCPA was also shown to suppress IL-2 production in the murine T cell lymphoma line, EL-4, and the human T cell lymphoma line, Jurkat (Zhao et al., 1999; Brundage et al., 2004). DCPA exposure results in both a decrease in IL-2 transcription and an increase in degradation of IL-2 mRNA (Zhao et al., 1999). The Jurkat cell line has exhibited a greater sensitivity to DCPA than murine T cells. IL-2 mRNA levels were reduced by $77 \% 48$ hours 
following in vitro exposure to $5 \mu \mathrm{M}$ DCPA (Brundage et al., 2004). In addition, $50 \mu \mathrm{M}$ DCPA reduced the binding of IL-2 transcription factor, AP-1, to the DNA following one hour of exposure (Brundage et al., 2004). AP-1 is a heterodimer of two proteins, c-jun and c-fos. DCPA exposure decreases phosphorylation as well as protein levels of c-jun following one hour of exposure, which implies a potential mechanism for decreased IL-2 production (Brundage et al., 2004). Analysis of electron-spin resonance showed that DCPA affects a small component of the cell membrane, but the way in which this disruption affects IL-2 production has yet to be elucidated (Brundage et al., 2003). Many intracellular signaling events inhibited by DCPA exposure have one or more calcium $\left(\mathrm{Ca}^{2+}\right)$ dependent steps. It was determined that DCPA exposure suppresses the normal elevated and sustained intracellular $\mathrm{Ca}^{2+}\left(\left[\mathrm{Ca}^{2+}\right]_{i}\right)$ that follows internal store depletion in the human leukemic $T$ cell line, Jurkat, and primary BALB/c mice $T$ cells (Lewis et al., 2008). This inhibition of $\mathrm{Ca}^{2+}$ influx is consistent with inhibition of the $\mathrm{Ca}^{2+}$ release-activated $\mathrm{Ca}^{2+}$ (CRAC) channel. Recent findings suggest that DCPA inhibits CRAC channels by reducing the aggregation of the $\mathrm{Ca}^{2+}$ sensor, stromal interaction molecule 1 (STIM1) (Lewis et al, unpublished data). These data suggest that DCPA is a novel inhibitor of STIM-1 aggregation (Lewis et al, unpublished data).

Although the immunotoxic effects of DCPA have been extensively studied, the way in which DCPA modulates intracellular functions leading to these effects is less understood. In order to understand the mechanism of DCPA's intracellular toxicity, it is necessary to determine whether the molecule actually transports into the cell. The following study was conducted with the intent to resolve this issue. 


\section{REFERENCES}

Ambrose, A. M., Larson, P. S., Borzelleca, J. F., and Hennigar, G. R., Jr. (1972). Toxicologic studies on 3',4'-dichloropropionanilide. Toxicology and applied pharmacology 23, 650-659.

Barnett, J. B., and Gandy, J. (1989). Effect of acute propanil exposure on the immune response of C57BI/6 mice. Fundam Appl Toxicol 12, 757-764.

Barnett, J. B., Gandy, J., Wilbourn, D., and Theus, S. A. (1992). Comparison of the immunotoxicity of propanil and its metabolite, 3,4-dichloroaniline, in C57BI/6 mice. Fundam Appl Toxicol 18, 628-631.

Blyler, G., Landreth, K. S., Lillis, T., Schafer, R., Theus, S. A., Gandy, J., and Barnett, J. B. (1994). Selective myelotoxicity of propanil. Fundam Appl Toxicol 22, 505-510.

Brundage, K. M., Barnett, J. B., and Mahaney, J. E. (2003). The amide class herbicide 3,4-dichloropropionanilide (DCPA) alters the mobility of hydrocarbon chains in Tlymphocyte but not macrophage membranes. Journal of toxicology and environmental health 66, 2253-2265.

Brundage, K. M., Schafer, R., and Barnett, J. B. (2004). Altered AP-1 (activating protein1) activity and c-jun activation in T cells exposed to the amide class herbicide 3,4-dichloropropionanilide (DCPA). Toxicol Sci 79, 98-105.

Cuff, C. F., Zhao, W., Nukui, T., Schafer, R., and Barnett, J. B. (1996). 3,4Dichloropropionanilide-induced atrophy of the thymus: mechanisms of toxicity and recovery. Fundam Appl Toxicol 33, 83-90. 
Dahchour, A., Bitton, G., Coste, C. M., and Bastide, J. (1986). Degradation of the herbicide propanil in distilled water. Bulletin of environmental contamination and toxicology 36, 556-562.

de la Rosa, P., Barnett, J. B., and Schafer, R. (2005). Characterization of thymic atrophy and the mechanism of thymocyte depletion after in vivo exposure to a mixture of herbicides. Journal of toxicology and environmental health 68, 81-98.

Frost, L. L., Neeley, Y. X., Schafer, R., Gibson, L. F., and Barnett, J. B. (2001). Propanil inhibits tumor necrosis factor-alpha production by reducing nuclear levels of the transcription factor nuclear factor-kappab in the macrophage cell line ic-21. Toxicology and applied pharmacology 172, 186-193.

Izmerov, N. F. (Ed.) (1984). Propanide-scientific reviews of Soviet literature on toxicity and hazard of chemicals, Moscow, Center of International Projects.

Lewis, T. L., Brundage, K. M., Brundage, R. A., and Barnett, J. B. (2008). 3,4Dichloropropionanilide (DCPA) inhibits T-cell activation by altering the intracellular calcium concentration following store depletion. Toxicol Sci 103, 97107.

Malerba, I., Castoldi, A. F., Parent-Massin, D., and Gribaldo, L. (2002). In vitro myelotoxicity of propanil and 3,4-dichloroaniline on murine and human CFUE/BFU-E progenitors. Toxicol Sci 69, 433-438.

Matsunaka, S. (1968). Propanil hydrolysis: inhibition in rice plants by insecticides. Science (New York, N.Y 160, 1360-1361. 
McMillan, D. C., Freeman, J. P., and Hinson, J. A. (1990). Metabolism of the arylamide herbicide propanil. I. Microsomal metabolism and in vitro methemoglobinemia. Toxicology and applied pharmacology 103, 90-101.

McMillan, D. C., Shaddock, J. G., Heflich, R. H., Casciano, D. A., and Hinson, J. A. (1988). Evaluation of propanil and its N-oxidized derivatives for genotoxicity in the Salmonella typhimurium reversion, Chinese hamster ovary/hypoxanthine guanine phosphoribosyl transferase, and rat hepatocyte/DNA repair assays. Fundam Appl Toxicol 11, 429-439.

Morse, D. L., Baker, E. L., Jr., Kimbrough, R. D., and Wisseman, C. L., 3rd (1979). Propanil-chloracne and methomyl toxicity in workers of a pesticide manufacturing plant. Clinical toxicology 15, 13-21.

Pruett, S. B., Fan, R., Zheng, Q., Myers, L. P., and Hebert, P. (2000). Modeling and predicting selected immunological effects of a chemical stressor (3,4dichloropropionanilide) using the area under the corticosterone concentration versus time curve. Toxicol Sci 58, 77-87.

Salazar, K. D., de la Rosa, P., Barnett, J. B., and Schafer, R. (2005). The polysaccharide antibody response after Streptococcus pneumoniae vaccination is differentially enhanced or suppressed by 3,4-dichloropropionanilide and 2,4dichlorophenoxyacetic acid. Toxicol Sci 87, 123-133.

Santillo, M., Rippa, C., Morte, R. D., Villani, G. R. D., Santangelo, F., Staiano, N., and Mondola, P. (1995). Enhancement of tissue lipoperoxidation in propanil-treated rats. Toxicology Letters $\mathbf{7 8 ,}$ 215-218. 
Singleton, S. D., and Murphy, S. D. (1973). Propanil (3,4-dichloropropionanilide)induced methemoglobin formation in mice in relation to acylamidase activity. Toxicology and applied pharmacology 25, 20-29.

Still, C. C., and Kuzirian, O. (1967). Enzyme detoxication of 3',4'-dichloropropionanilide in rice and barnyard grass, a factor in herbicide selectivity. Nature 216, 799-800.

Ustyugova, I. V., Frost, L. L., Van Dyke, K., Brundage, K. M., Schafer, R., and Barnett, J. B. (2007). 3,4-dichloropropionaniline suppresses normal macrophage function. Toxicol Sci 97, 364-374.

Watson, V. A., Barnett, J. B., and Schafer, R. (2000). In vivo cytokine production and resistance to infection after acute exposure to 3,4-dichloropropionaniline. Journal of toxicology and environmental health 60, 391-406.

Wauchope, R. D., Buttler, T. M., Hornsby, A. G., Augustijn-Beckers, P. W., and Burt, J. P. (1992). The SCS/ARS/CES pesticide properties database for environmental decision-making. Reviews of environmental contamination and toxicology 123, 1155.

Williams, C. H., Jacobsen, K.H. (1966). An acylamidase in mammalian liver hydrolyzing the herbicide 3,4-dichloropropionanilide. Toxicology and applied pharmacology $\mathbf{9}$, 459-500.

Xie, Y. C., Schafer, R., and Barnett, J. B. (1997). The immunomodulatory effects of the herbicide propanil on murine macrophage interleukin-6 and tumor necrosis factor-alpha production. Toxicology and applied pharmacology 145, 184-191 . 
Zhao, W., Schafer, R., and Barnett, J. B. (1998). Cytokine production by C57BL/6 mouse spleen cells is selectively reduced by exposure to propanil. Journal of toxicology and environmental health 55, 107-120.

Zhao, W., Schafer, R., and Barnett, J. B. (1999). Propanil affects transcriptional and posttranscriptional regulation of IL-2 expression in activated EL-4 cells. Toxicology and applied pharmacology 154, 153-159.

Zhao, W., Schafer, R., Cuff, C. F., Gandy, J., and Barnett, J. B. (1995). Changes in primary and secondary lymphoid organ T-cell subpopulations resulting from acute in vivo exposure to propanil. J Toxicol Environ Health 46, 171-181. 
Subcellular localization of the amide class herbicide 3,4-dichloropropionanilide (DCPA) in T cells and hepatocytes

Miranda L. Hanson ${ }^{1}$, Cody J. Peer ${ }^{2}$, Rodney Brundage ${ }^{1}$, Patrick Callery ${ }^{2}$, Kathleen Brundage $^{1}$, Rosana Schafer ${ }^{1}$, Sergei Eremin ${ }^{3}$, and John B. Barnett ${ }^{1}$; ${ }^{1}$ Department of Microbiology, Immunology, and Cell Biology, ${ }^{2}$ Department of Basic Pharmaceutical Sciences, School of Pharmacy, West Virginia University, Morgantown, WV; ${ }^{3}$ Department of Chemistry, M. V. Lomonosov Moscow State University, Moscow, Russian Federation

Running title: Subcellular localization of DCPA

Correspondence to:

John B. Barnett, Ph.D.

Department of Microbiology, Immunology and Cell Biology

PO Box 9177

West Virginia University

Morgantown, WV. 26506-9177

(T). 304-293-4029; (F) 304-293-7823

jbarnett@hsc.wvu.edu 


\section{ABSTRACT}

3,4-Dichloropropionanilide (DCPA), or propanil, a post-emergent herbicide used on rice and wheat crops in the United States, is immunotoxic in vivo and in vitro. Although it has been documented that DCPA exerts differential effects on specific immune cell types and is toxic to the liver, the subcellular localization from which DCPA modulates immune cells and hepatocytes has not been identified. In this study, Jurkat T cells were exposed to $100 \mu \mathrm{M}$ DCPA for 1.5 hours after stimulation with antiCD3/CD28. Following incubation, the cytosol, membrane/organelle, and nuclear/cytoskeletal fractions of the cells were isolated. In addition, hepatocytes from C57BI/6 mice were exposed to $100 \square \mathrm{M}$ DCPA for 1.5 hours. Following incubation, the cytosol, light mitochondrial, and peroxisomal fractions of the cells were isolated. DCPA, when present, was removed from each cell fraction by liquid-liquid extraction. The extraction product was then analyzed for the presence of DCPA using liquid chromatography tandem mass spectrometry (LC-MS/MS). The cellular uptake of DCPA was monitored by detection of the molecular ion and product ion of DCPA. The analyses demonstrate that DCPA, a lipophilic compound, localizes primarily in the cytosol of T cells and hepatocytes. Low levels of DCPA were detected in the light mitochondrial fraction in the hepatocytes, while DCPA was absent in the membrane/organelle and nuclear/cytoskeletal fractions in T cells, and the peroxisome fraction in hepatocytes. These results indicate that DCPA is able to cross the plasma membrane and is accessible to intracellular immunomodulatory effectors. 


\section{INTRODUCTION}

Propanil (3,4-dichloropropionalide, DCPA) is an herbicide used extensively on rice and wheat crops in the United States. DCPA is in the acetanilide chemical family, and is a dichlorinated aromatic compound of low molecular weight. The major metabolite of DCPA is 3,4-dichloroaniline (DCA), which is mediated through an acylamidase-catalyzed hydrolysis of the parent compound (Singleton and Murphy, 1973; McMillan et al., 1990). Individuals involved in agriculture, in particular, are at risk for high-level exposure to DCPA. DCPA can be absorbed through the respiratory tract, the gastrointestinal tract, and the intact skin (Richards et al., 2001). In experimental animals, the half life of DCPA is rapid without respect to route of entry. Following a single intraperitoneal dose of DCPA in rats, the complete elimination from the body is within 48 to 72 hours (Izmerov, 1984). The pharmacokinetic profile of DCPA in humans is not available in the literature.

There are well-known immunotoxic effects on various compartments of the immune system following in vitro DCPA exposure, including T-helper lymphocytes (Cuff et al., 1996), B lymphocytes (de la Rosa et al., 2003), and macrophages (Frost et al., 2001). DCPA exposure decreases contact hypersensitivity responses, reduces proliferative responses to T-and B-cell mitogens, and impedes mixed lymphocyte reactions (Barnett and Gandy, 1989). Exposure to DCPA has also been found to induce splenomegaly and thymic atrophy in a dose-dependent manner in mice at 7 days postexposure (Barnett and Gandy, 1989). In addition to immunotoxicity, reports have demonstrated that DCPA is hepatotoxic to humans (De Silva and Bodinayake, 1997) 
and rodents (Santillo et al., 1995). Following absorption by mammals, DCPA is quickly hydrolyzed, primarily to 3,4-DCA by the liver enzyme acylamidase (Williams, 1966). DCA is then metabolized to 6-hydroxy-3,4-dicloroaniline and N-hydroxy-3,4dicloroaniline. Oxidation of DCPA occurs, most often, on the propionyl group of and at the 6-position on the phenyl ring (McMillan et al., 1990).

Although it has been documented that DCPA exerts differential effects on specific immune cell types and is hepatotoxic, to date, the subcellular localization from which DCPA modulates immune cells and hepatocytes has not been examined. The high lipophilicity of DCPA has led to the suggestion of a higher affinity of DCPA for membranes (Corsini et al., 2007). The aim of this study is to determine the localization of DCPA in T cells and hepatocytes following in vitro exposure. A combination of differential detergent fractionation (DDF) and centrifugation was used to thoroughly separate the cellular compartments. The product from a liquid-liquid extraction was analyzed using liquid chromatography-tandem mass spectrometry (LC-MS/MS). Our results demonstrate that DCPA, a lipophilic compound (Finizio, 1997), localizes primarily in the cytosol of both $\mathrm{T}$ cells and hepatocytes. This study improves our understanding of the cellular location in which DCPA exerts its toxic effects. 


\section{MATERIALS AND METHODS}

\section{$T$ cell treatment with DCPA}

Experiments were performed using the human $\mathrm{T}$ cell leukemia cell line, Jurkat clone E6-1, obtained from the ATCC (American Tissue Culture Collection, Manassas, VA). Jurkat cells were maintained in complete Roswell Park Memorial Institute (RPMI) media (Mediatech Inc., Herndon, VA) supplemented with 10\% heat inactivated fetal bovine serum (v/v) (FBS) (Hyclone Inc. Logan, UT), 100 units/ml penicillin (BioWhittaker), $100 \mu \mathrm{g} / \mathrm{ml}$ streptomycin (Bio Whittaker), $20 \mathrm{mM}$ glutamine (BioWhittaker) and $50 \mu \mathrm{M}$ 2-mercaptoethanol (Sigma, St. Louis, MO). The cultures were kept at $37^{\circ} \mathrm{C}$ in $5 \% \mathrm{CO}_{2}$. Cells in suspension were grown to obtain approximately $5 \times 10^{7}$ cells. A 10 $\mathrm{ml}$ volume of cells was stimulated with anti-CD3 $(10 \mu \mathrm{g} / \mathrm{ml})$ and anti-CD28 $(2 \mu \mathrm{g} / \mathrm{ml})(B D$ PharMingen, San Diego, CA) and at the same time exposed to $100 \mu \mathrm{M}$ DCPA or ethanol (vehicle control) for 1 hour $(\mathrm{h})$ at $37^{\circ} \mathrm{C}, 5 \% \mathrm{CO}_{2}$. The cells were harvested and centrifuged at $1200 \mathrm{rpm}$ for 8 minutes $(\min )$ at $4^{\circ} \mathrm{C}$.

Protein Extraction by Differential Detergent Fractionation (DDF) and Centrifugation of $T$ cells

DDF relies on detergents to sequentially extract proteins from eukaryotic cells. The cytosolic fraction was extracted by resuspending cells in $1 \mathrm{ml}$ of $0.01 \%$ digitonin solution and incubated on ice for $30 \mathrm{~min}$. The suspension was centrifuged at $14,000 \times \mathrm{g}$ for 2 min at $4^{\circ} \mathrm{C}$. Digitonin interacts with cholesterol to form pores in the cell membrane 
and extract soluble proteins from the cytosol. The membrane/organelle fraction was extracted by resuspending the pellet from the digitonin extraction step in $0.6 \mathrm{ml} 2 \%$ Triton-X 100 solution and incubated on ice for $1 \mathrm{~h}$. The suspension was centrifuged at $14,000 \times g$ for $10 \mathrm{~min}$ at $4^{\circ} \mathrm{C}$. Triton $\mathrm{X}-100$ solubilizes membrane and organelle proteins. The nuclear/cytoskeletal fraction was extracted by dissolving the pellet from the TX-100 extraction step in $1 \mathrm{ml} 4 \%$ CHAPS solution for $1-2 \mathrm{~h}$ at room temperature (RT) The suspension was centrifuged for $10 \mathrm{~min}$ at $14,000 \times \mathrm{g}$ at RT to remove insoluble material. CHAPS results in the permeabilization of the nuclear envelope. The pellet was washed with Dulbecco's phosphate buffered saline (DPBS) after each fraction removal to limit cross-contamination.

\section{Western blot}

Protein quantitation was determined using the 2D Quant Kit (Amersham Biosciences). A $30 \mu \mathrm{g}$ aliquot of each fraction sample was boiled for $5 \mathrm{~min}$ to denature the proteins and electrophoresed through a $12 \%$ Tris polyacrylamide gel with a $4 \%$ stacking gel at $15 \mathrm{mAmps}$ for $18 \mathrm{~h}$. Proteins were transferred onto Hybond-P membranes (Amersham Pharmacia, Piscataway, NJ) at $200 \mathrm{~V}, 0.5 \mathrm{~mA}$ for $2 \mathrm{~h}$. Blots were washed in TBS for 5 min at RT, blocked for $1 \mathrm{~h}$ in TBS $+0.1 \%$ Tween 20 (TBS/T) plus $5 \%$ dry milk at RT and then washed three times in TBS/T. Blots were incubated overnight at $4^{\circ} \mathrm{C}$ with primary antibodies specific for GAPDH, Oct-1, and Vdac/Porin (Santa Cruz Biotechnology, CA) in TBS/T plus 5\% BSA. The next day, blots were washed three times in TBS/T, incubated for $1 \mathrm{~h}$ at room temperature with anti-Biotin (Cell Signaling Technology, Inc., Danvers, MA) and a rabbit anti-goat IgG-HRP (Sigma- 
Aldrich). Finally, the blots were washed three times in TBS/T and developed using Phototope-HRP detection kit for western blots (Cell Signaling Technology, Inc) and bands were visualized on X-Ray film (BioMax MR, Eastman Kodak Company).

Mouse hepatocyte isolation

Female C57Bl/6 mice at 8-10 weeks of age were obtained from Hilltop Lab Animals, Inc (Scottsdale, PA). Normal mouse hepatocytes were isolated using the method described by Muller et al. (Muller et al., 1972). All animal methods were carried out utilizing an ACUC approved protocol. Briefly, mice were anesthetized utilizing IP injection of Pentabarbitol (100 mg/kg). The liver was exposed and perfused with Krebs Ringer with glucose $(3.6 \mathrm{mg} / \mathrm{ml})$ and $0.1 \mathrm{mM}$ EGTA to remove the blood, while maintaining temperature with a heating lamp. Beldzyme 3 (Roche) was then perfused in slowly $\left(50 \mathrm{ml}\right.$ of $0.02 \mathrm{mg} / \mathrm{ml}$ in Krebs Ringer plus glucose and $\mathrm{CaCl}_{2}(1.37 \mathrm{mM})$. The liver was gently massaged following perfusion to assist in distribution of the enzyme solution. The liver was then carefully removed and minced in chilled perfusion buffer. Cells were dispersed with a large bore pipette and passed through a $70 \mu \mathrm{m}$ filter to remove debris. Cells were washed 3 times by centrifugation $\left(50 \times g, 2 \mathrm{~min}, 4^{\circ} \mathrm{C}\right)$ with cold culture media (DMEM supplemented with 10\% FBS and 100 units/ml penicillin, 100 $\mu \mathrm{g} / \mathrm{ml}$ streptomycin, $20 \mathrm{mM}$ glutamine and $50 \mu \mathrm{M}$ 2-mercaptoethanol). Cells were cultured overnight on collagen coated dishes $\left(37^{\circ} \mathrm{C}, 5 \% \mathrm{CO}_{2}\right)$ prior to exposure to DCPA. 


\section{Peroxisome purification}

Overnight cultures of isolated primary hepatocytes were incubated with $10 \rrbracket \mathrm{M}$ DCPA or ethanol for $1.5 \mathrm{~h}$ at $37^{\circ} \mathrm{C}, 5 \% \mathrm{CO}_{2}$ prior to preparation of peroxisomes. Cells were scraped from the dishes and pelleted $\left(300 \times \mathrm{g}, 10 \mathrm{~min}, 4^{\circ} \mathrm{C}\right)$. The resulting cell pellets were resuspended in $3 \mathrm{ml}$ of ice cold homogenization buffer $(\mathrm{HM}$; $9 \%$ sucrose, 1mM EDTA, 10mM Tris, 5mM MOPS, 0.1\% ethanol, $\mathrm{pH} 7.2$ ). The resuspended cells were homogenized on ice using 50 strokes of a $\mathrm{P} / \mathrm{J}$ homogenizer fitted with a Teflon pestle and attached to a variable speed hand drill. The homogenate was centrifuged $\left(500 \times g, 5 \mathrm{~min}, 4^{\circ} \mathrm{C}\right)$ and the supernatant was saved. The remaining cell pellet was rehomogenized and centrifuged. The resulting supernatant fractions were combined (crude homogenate fractions). The crude homogenates were centrifuged in corex tubes $\left(6000 \times \mathrm{g}, 10 \mathrm{~min}, 4^{\circ} \mathrm{C}\right)$. The pellets were resuspended in $3 \mathrm{ml}$ of ice cold HM (Pellet $\# 1$ ). The resulting supernatants (Supernatant \#1) were centrifuged in corex tubes $\left(20,000 \times g, 15 \mathrm{~min}, 4^{\circ} \mathrm{C}\right)$. The resulting supernatant was reserved (Supernatant \#2Cytosol Fraction) and the pellet was resuspended in $3 \mathrm{ml}$ of ice cold HM buffer (Light Mitochondrial Fraction). The resuspended pellet was then centrifuged over a cushion of $30 \%$ Optiprep (Sigma) using a Ti50.2 rotor $\left(40,000 \times g, 3.25 \mathrm{~h}, 4^{\circ} \mathrm{C}\right)$ The pellet was then resuspended in $600 \mu \mathrm{l}$ of ice cold HM buffer (crude peroxisome fraction)

\section{Mass spectrometric analysis of cell fractions}

Volumes of all fractions were adjusted using PBS to achieve a protein concentration of $0.5 \mu \mathrm{g} / \mu \mathrm{l}$. DCPA was extracted from cell fractions using a liquid-liquid extraction procedure as follows: $25 \mu \mathrm{l}$ of each cell fraction was diluted to $500 \mu \mathrm{l}$ with 
deionized water. Then, $50 \mu \mathrm{l}$ of the internal standard acetaminophen was added at a final concentration of $1.1 \mu \mathrm{g} / \mathrm{ml}$. To the vortexed sample, $2 \mathrm{ml}$ of ethyl acetate was added and shaken vigorously. This served to partition the DCPA and acetaminophen into the organic phase. The samples were centrifuged at $3000 \mathrm{rpm}$ for $5 \mathrm{~min}$ at RT to ensure separation of layers before keeping the ethyl acetate extract. The organic portions were dried under a stream of nitrogen and reconstituted with $100 \mu \mathrm{l}$ of deionized water. A 5-point standard curve of a DCPA concentration range of 5-500 $\mathrm{ng} / \mathrm{ml}$ was used to estimate the quantity of DCPA in cell fractions.

LC-MS/MS was used to determine DCPA localization in cells. High performance liquid chromatography (HPLC) separation was achieved using a reversed-phase $\mathrm{C}_{8}(50$ $\mathrm{mm} \times 4.6 \mathrm{~mm}$ ) column with a flow rate of $200 \mu \mathrm{l} / \mathrm{min}$ and a gradient as follows: $80 \%$ mobile phase $\mathrm{A}(0.05 \%$ formic acid, aq) from 0-1.5 min; increased from $20-60 \%$ mobile phase B (0.05\% Formic acid in acetonitrile) from 1.5-3.5 min; 60\% B held from 3.5-7 min; column re-equilibrated from $60-20 \%$ B from 7-9 min. Tandem mass spectrometry operated in the positive ion mode with sheath gas (nitrogen) flow rate: 80 arbitrary (arb.) units (with 20 arb. units auxiliary gas flow rate), spray voltage $5.2 \mathrm{kV}$, capillary voltage 9 $\mathrm{V}$, and heated capillary temperature 300C. Acetaminophen eluted at approximately 2 min. From 0-4 min, MS/MS was performed on $\mathrm{m} / \mathrm{z} 152$ (acetaminophen) and the selected ion monitored (SRM) range was set for $\mathrm{m} / \mathrm{z} 110$ (fragment of acetaminophen). From 4-10 min, MS/MS was performed on $\mathrm{m} / \mathrm{z} 218 \pm 4$ amu (to encompass all ionized forms of DCPA of $m / z 216,218$, and 220). A SRM was set up with a range of $m / z 162 \pm$ 4 amu (to encompass all DCPA MS/MS fragments of $\mathrm{m} / \mathrm{z} 160,162$, and 164 , respectively). 


\section{Results and Discussion}

Analysis of fractionated T cells following stimulation and treatment with $100 \mu \mathrm{M}$ DCPA for $1.5 \mathrm{~h}$ demonstrated that DCPA localizes in the cytosol (Figure $1 \mathrm{~A}$ ) at a concentration of $26.26 \pm 2.02 \mathrm{ng} / \mathrm{ml}$ (Table 1). DCPA was not detected in the membrane/organelle fraction (Figure 1B) or in the nuclear/cytoskeletal fraction (Figure 1C). Therefore, DCPA, a lipophilic molecule, passes through the plasma membrane and resides in the cytosol of T cells following $1.5 \mathrm{~h}$ of exposure.

Analysis of fractionated hepatocytes following treatment with DCPA for $1.5 \mathrm{~h}$ demonstrated that the molecule localizes mostly in the cytosol (Figure 2A) at a concentration of $120.24 \pm 5.78 \mathrm{ng} / \mathrm{ml}$ (Table 1). DCPA was also detected in the light mitochondrial fraction (Figure 2B), but the level was minimal relative to the level detected in the cytosol (Table 1). There was no DCPA detected in the peroxisomal fraction of hepatocytes (Figure 2C). Therefore, DCPA localizes predominately in the cytosol of hepatocytes following $1.5 \mathrm{~h}$ of exposure.

The greater DCPA concentration observed in the hepatocyte cytosol $(120.24 \pm 5.78 \mathrm{ng} / \mathrm{ml})$ compared to that in the T cell cytosol $(26.26 \pm 2.02 \mathrm{ng} / \mathrm{ml})$ is likely attributed to differences in cell size and cell composition. Hepatocytes are among the largest of cells, with an average diameter of $18-22 \mu \mathrm{m}$. In addition, they display an eosinophilic cytosplasm which contains numerous mitochondria. The high density of mitochondria present in hepatocytes may contribute to identification of DCPA in those organelles in hepatocytes and not T cells. T cells have an average diameter of 7-12 $\mu \mathrm{m}$ with the nucleus being the major constituent of the cell, thus there is little eosinophilic 
cytoplasm. The finding that DCPA is only detected in the cytosol of T cells coupled with the size of this constituent, suggests that DCPA's mechanism of action has specificity.

We hypothesized that DCPA exerts its effects on immune cells and hepatocytes by interfering with cell activation and cell signaling processes at the cell membrane, due to DCPA being a highly hydrophilic, lipophilic compound. Our finding that DCPA is not in the membrane does not eliminate the possibility that DCPA is affecting membrane proteins or channels as it migrates into the cytosol. An earlier finding in our lab demonstrated that DCPA exposure does not disrupt the motional properties of lipid hydrocarbon chains in the bilayer, but does alter distribution of lipids in distinct motional environments in the membrane (Brundage et al., 2003). The present study provides an explanation for the limited effect observed in hydrocarbon chain mobility. The finding that DCPA is able to move through the membrane of T cells and hepatocytes and localize in the cytosol will aid in the understanding of DCPA's mechanism of toxicity to cellular functions. 
Figure 1
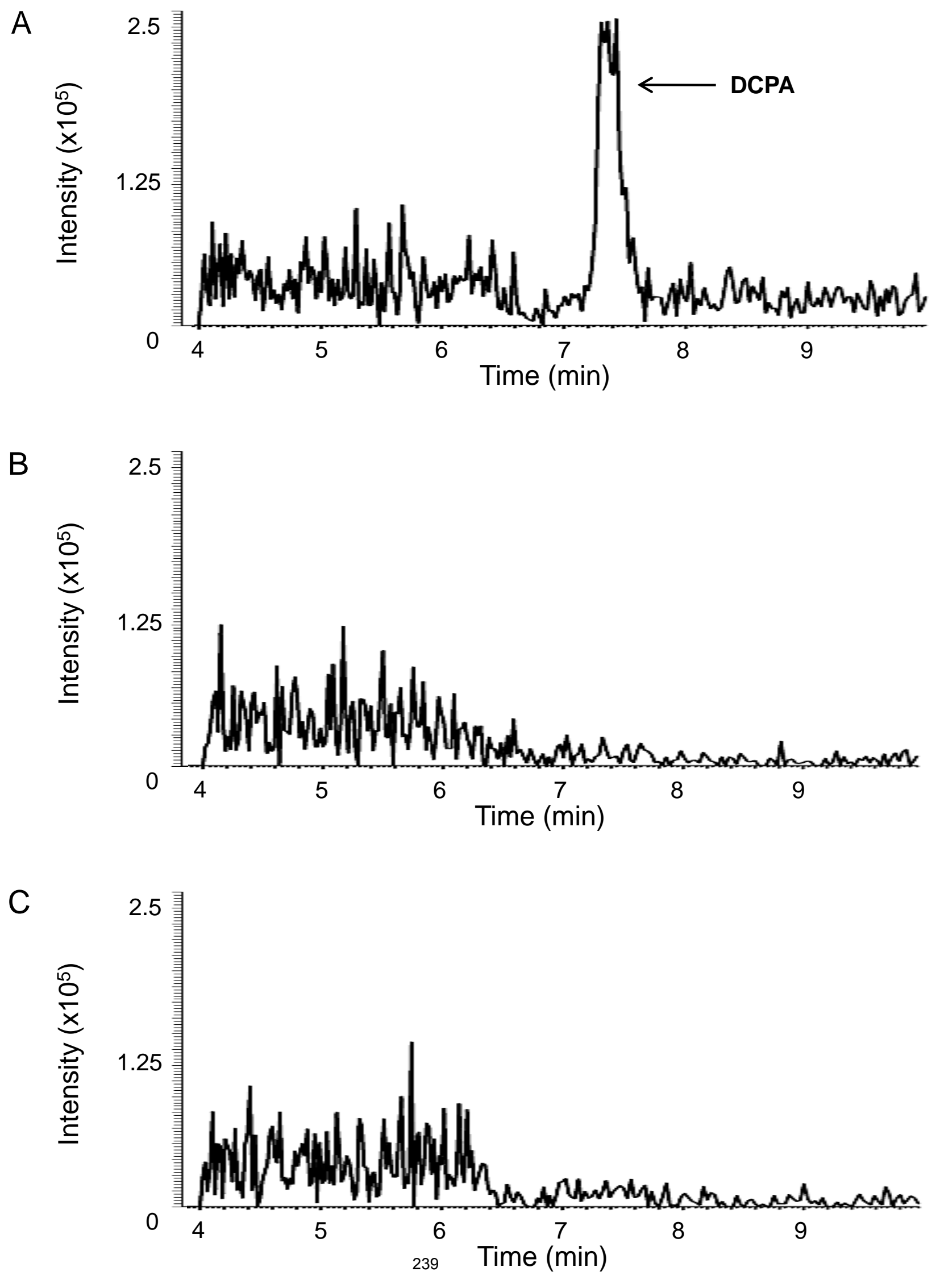
Figure 1. Chromatograms of DCPA localization in T cells. Jurkat $T$ cells were stimulated with anti-CD3/CD28 and exposed to $100 \mu \mathrm{M}$ DCPA for 1.5 hours. Cells were fractionated using DDF and centrifugation. LC-MS/MS was used to determine DCPA location in cell fractions. Acetaminophen was used as an internal standard. Protein concentration of each fraction was $0.5 \mu \mathrm{g} / \mu \mathrm{l}$. (A) Cytosol fraction, (B) Membrane/Organelle fraction, (C) Nuclear/Cytoskeleton fraction. Representative of 3 separate experiments. 
Figure 2

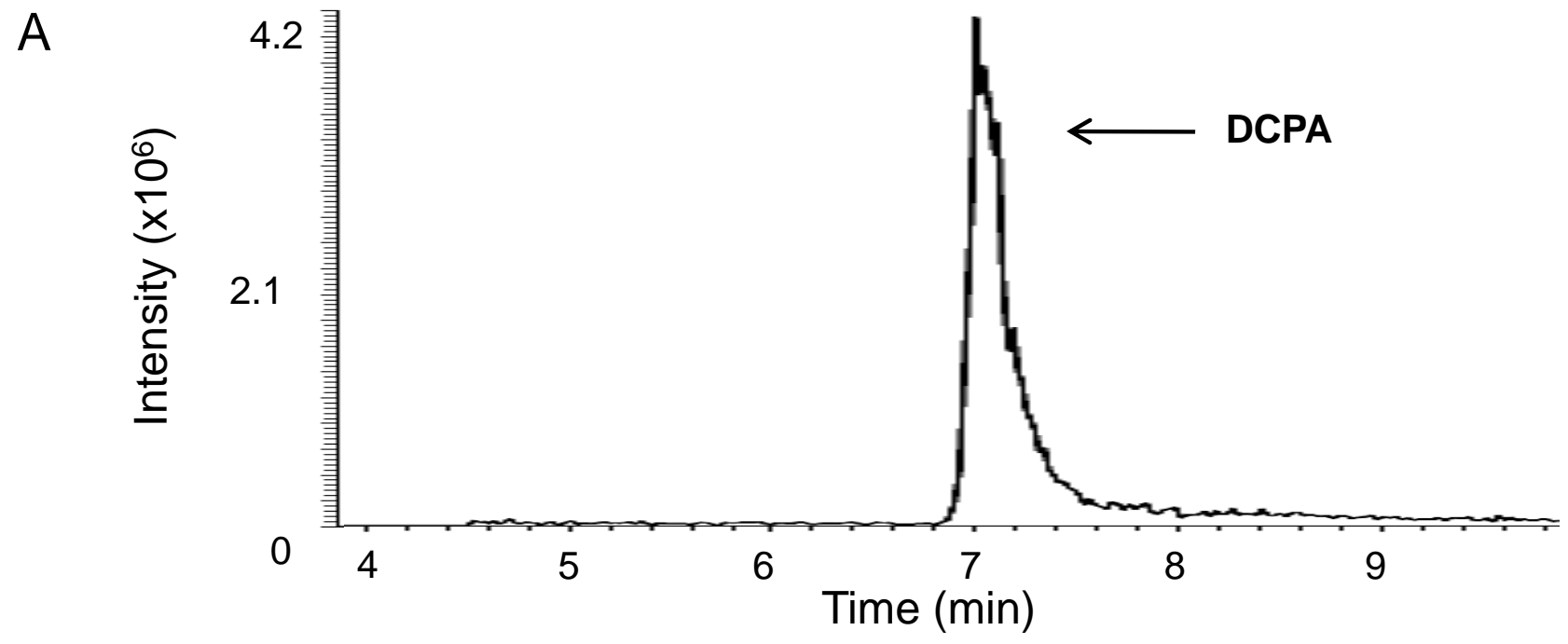

B

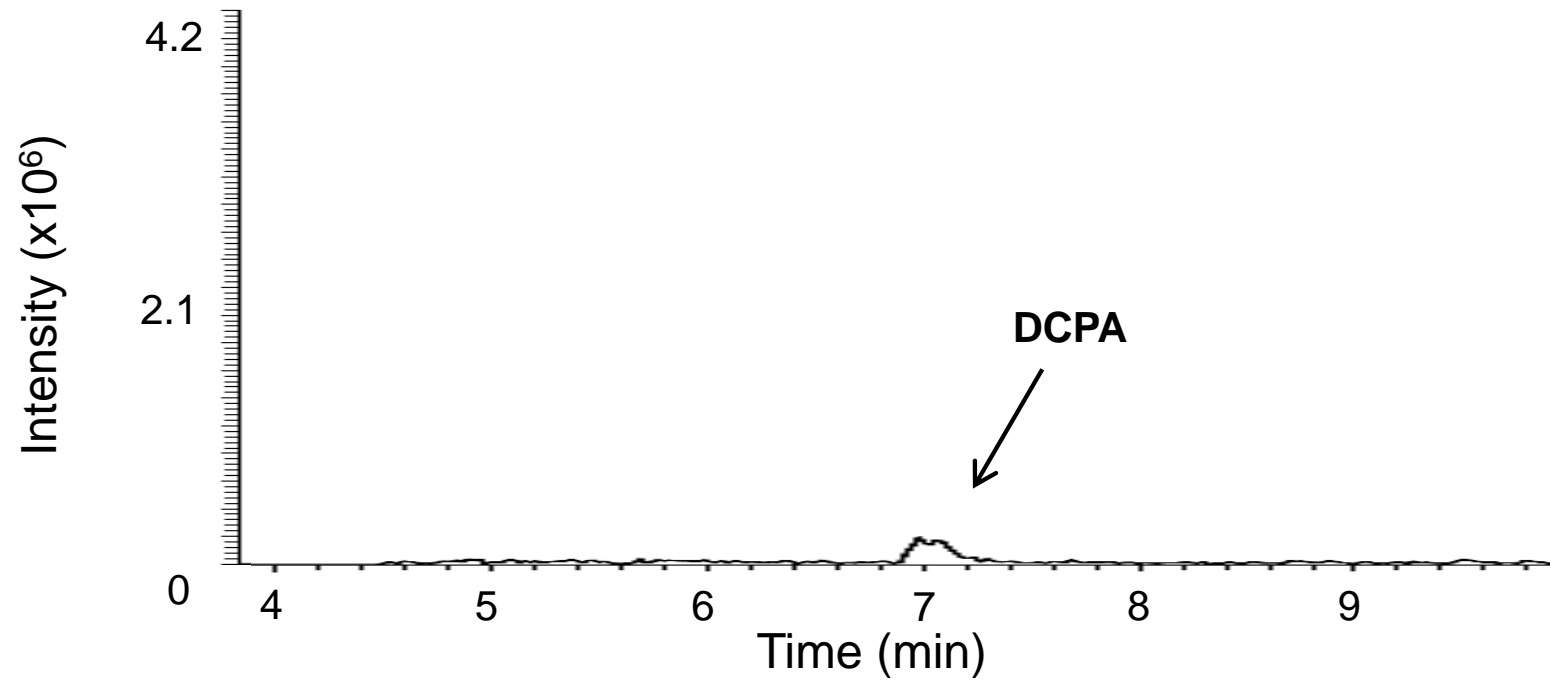

C

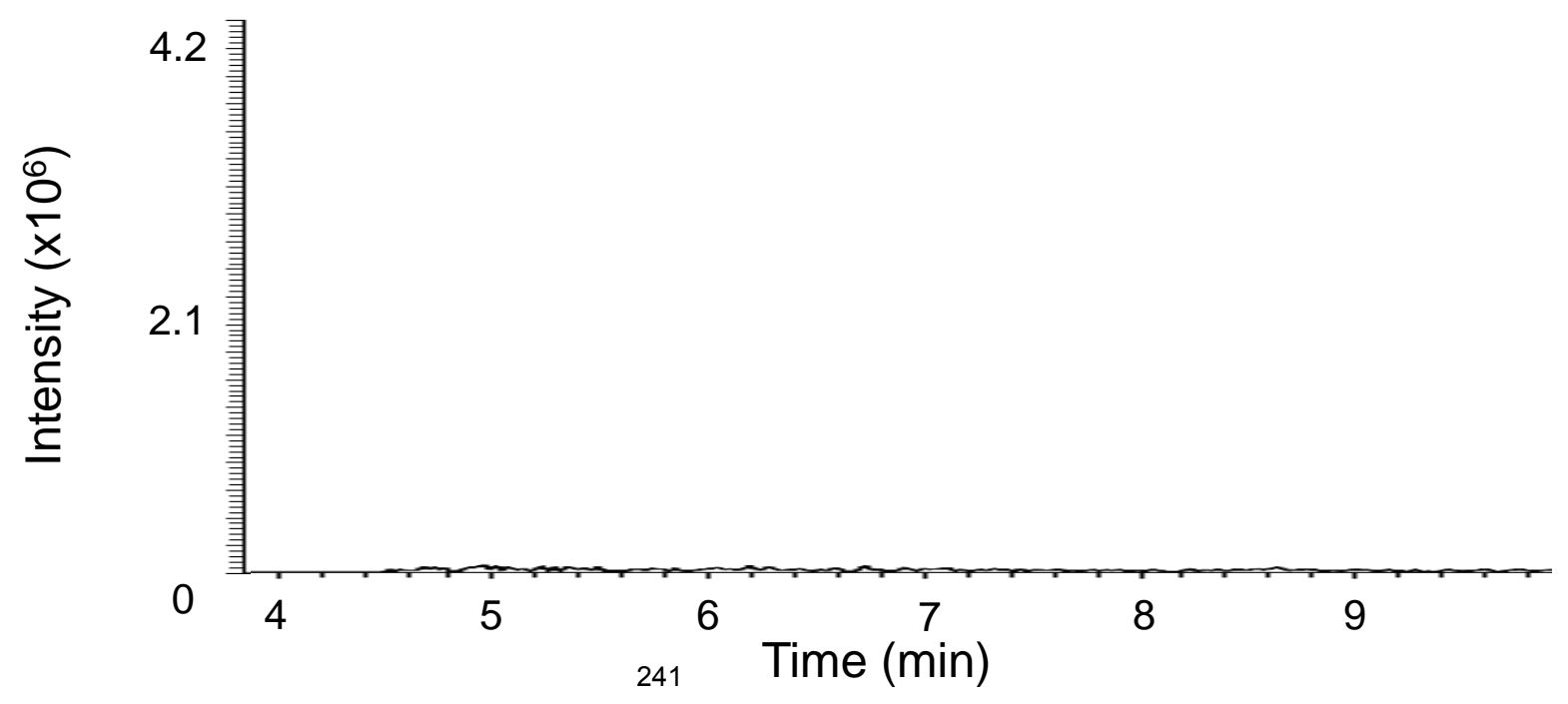


Figure 2. Chromatograms of DCPA localization in hepatocytes. Primary mouse hepatocytes were exposed to $100 \mu \mathrm{M}$ DCPA for 1.5 hours. Cells were fractionated using homogenization and centrifugation. LC-MS/MS was used to determine DCPA location in cell fractions. Acetaminophen was used as an internal standard. Protein concentration of each fraction was $0.5 \mu \mathrm{g} / \mu \mathrm{l}$. (A) Cytosol fraction, (B) Light Mitochondrial fraction, (C) Peroxisome fraction. Representative of 3 separate experiments. 
Table 1. DCPA concentration in $\mathrm{T}$ cell and hepatocyte fractions.

\begin{tabular}{|l|l|l|l|}
\hline T cells & $\begin{array}{l}\text { DCPA concentration } \\
(\mathbf{n g} / \mathbf{m l})\end{array}$ & Hepatocytes & $\begin{array}{l}\text { DCPA concentration } \\
(\mathbf{n g} / \mathbf{m l})\end{array}$ \\
\hline Cytosol & $26.26 \pm 2.02$ & Cytosol & $120.24 \pm 5.78$ \\
\hline Membrane/organelle & 0 & Light mitochondrial & $25.30 \pm 3.14$ \\
\hline Nuclear/cytoskeletal & 0 & Peroxisomal & 0 \\
\hline
\end{tabular}

Each value is mean \pm SEM, $n=3$ 


\section{REFERENCES}

Barnett, J. B., and Gandy, J. (1989). Effect of acute propanil exposure on the immune response of C57Bl/6 mice. Fundam Appl Toxicol 12, 757-764.

Brundage, K. M., Barnett, J. B., and Mahaney, J. E. (2003). The amide class herbicide 3,4dichloropropionanilide (DCPA) alters the mobility of hydrocarbon chains in Tlymphocyte but not macrophage membranes. J Toxicol Environ Health A 66, 2253-2265.

Corsini, E., Codeca, I., Mangiaratti, S., Birindelli, S., Minoia, C., Turci, R., Viviani, B., Facchi, A., Vitelli, N., Lucchi, L., Galli, C. L., Marinovich, M., and Colosio, C. (2007). Immunomodulatory effects of the herbicide propanil on cytokine production in humans: In vivo and in vitro exposure. Toxicology and applied pharmacology 222, 202-210.

Cuff, C. F., Zhao, W., Nukui, T., Schafer, R., and Barnett, J. B. (1996). 3,4Dichloropropionanilide-induced atrophy of the thymus: mechanisms of toxicity and recovery. Fundam Appl Toxicol 33, 83-90.

de la Rosa, P., Barnett, J., and Schafer, R. (2003). Loss of pre-B and IgM(+) B cells in the bone marrow after exposure to a mixture of herbicides. Journal of toxicology and environmental health 66, 2299-2313.

De Silva, W. A., and Bodinayake, C. K. (1997). Propanil poisoning. The Ceylon medical journal 42, 81-84.

Finizio, A., Vighi, M., and Sandroni, D. (1997). Determination of n-octanol/water partition coefficient (Kow) of pesticide critical review and comparison of methods. Chemosphere 34, 131-161.

Frost, L. L., Neeley, Y. X., Schafer, R., Gibson, L. F., and Barnett, J. B. (2001). Propanil inhibits tumor necrosis factor-alpha production by reducing nuclear levels of the transcription 
factor nuclear factor-kappab in the macrophage cell line ic-21. Toxicology and applied pharmacology 172, 186-193.

Izmerov, N. F. (Ed.) (1984). Propanide-scientific reviews of Soviet literature on toxicity and hazard of chemicals, Moscow, Center of International Projects.

McMillan, D. C., Freeman, J. P., and Hinson, J. A. (1990). Metabolism of the arylamide herbicide propanil. I. Microsomal metabolism and in vitro methemoglobinemia. Toxicology and applied pharmacology 103, 90-101.

Muller, M., Schreiber, M., Kartenbeck, J., and Schreiber, G. (1972). Preparation of single-cell suspensions from normal liver, regenerating liver, and Morris hepatomas 9121 and 5123tc. Cancer research 32, 2568-2576.

Richards, S. M., McClure, G. Y., Lavy, T. L., Mattice, J. D., Keller, R. J., and Gandy, J. (2001). Propanil (3,4-dichloropropionanilide) particulate concentrations within and near the residences of families living adjacent to aerially sprayed rice fields. Archives of environmental contamination and toxicology 41, 112-116.

Santillo, M., Rippa, C., Morte, R. D., Villani, G. R. D., Santangelo, F., Staiano, N., and Mondola, P. (1995). Enhancement of tissue lipoperoxidation in propanil-treated rats. Toxicology Letters 78, 215-218.

Singleton, S. D., and Murphy, S. D. (1973). Propanil (3,4-dichloropropionanilide)-induced methemoglobin formation in mice in relation to acylamidase activity. Toxicology and applied pharmacology 25, 20-29.

Williams, C. H., Jacobsen, K.H. (1966). An acylamidase in mammalian liver hydrolyzing the herbicide 3,4-dichloropropionanilide. Toxicology and applied pharmacology 9, 459-500. 


\section{GENERAL DISCUSSION II}

The aim of the study described in the Appendix of this dissertation was to determine the subcellular localization of the herbicide DCPA. Due to the immunotoxic effects of DCPA on T cells (Barnett et al., 1992; Zhao et al., 1995; Cuff et al., 1996; Zhao et al., 1998; Zhao et al., 1999; Brundage et al., 2004; Lewis et al., 2008), the localization of DCPA in Jurkat T cells was determined. Hepatocytes were also analyzed in the study due to the liver being the major site for metabolism of DCPA and because of reports demonstrating that DCPA is hepatotoxic to humans (De Silva and Bodinayake, 1997) and rodents (Santillo et al., 1995). We hypothesized that due to DCPA's lipophilic and hydrophobic nature, it would localize in the cell membrane. Analysis of the cytosol, membrane/organelle, and nuclear fractions of $\mathrm{T}$ cells demonstrated that DCPA does not reside in the membrane, but rather accumulates in the cytosol. Similarly, analysis of the cytosol, light mitochondrial, and peroxisomal fractions of hepatocytes demonstrated that DCPA accumulates mostly in the cytosol, while minimal levels were detected in the light mitochondrial fraction. The results suggest that cell size and composition affects DCPA accumulation and, to some degree, its localization. Knowing the subcellular localization of

DCPA in T cells and hepatocytes will aid in the understanding of DCPA's mechanism of toxicity to cellular functions. 


\section{REFERENCES}

Barnett, J. B., Gandy, J., Wilbourn, D., and Theus, S. A. (1992). Comparison of the immunotoxicity of propanil and its metabolite, 3,4-dichloroaniline, in C57BI/6 mice. Fundam Appl Toxicol 18, 628-631.

Brundage, K. M., Schafer, R., and Barnett, J. B. (2004). Altered AP-1 (activating protein1) activity and c-jun activation in T cells exposed to the amide class herbicide 3,4-dichloropropionanilide (DCPA). Toxicol Sci 79, 98-105.

Cuff, C. F., Zhao, W., Nukui, T., Schafer, R., and Barnett, J. B. (1996). 3,4Dichloropropionanilide-induced atrophy of the thymus: mechanisms of toxicity and recovery. Fundam Appl Toxicol 33, 83-90.

De Silva, W. A., and Bodinayake, C. K. (1997). Propanil poisoning. The Ceylon medical journal 42, 81-84.

Lewis, T. L., Brundage, K. M., Brundage, R. A., and Barnett, J. B. (2008). 3,4Dichloropropionanilide (DCPA) inhibits T-cell activation by altering the intracellular calcium concentration following store depletion. Toxicol Sci 103, 97107.

Santillo, M., Rippa, C., Morte, R. D., Villani, G. R. D., Santangelo, F., Staiano, N., and Mondola, P. (1995). Enhancement of tissue lipoperoxidation in propanil-treated rats. Toxicology Letters $\mathbf{7 8}, 215-218$.

Zhao, W., Schafer, R., and Barnett, J. B. (1998). Cytokine production by C57BL/6 mouse spleen cells is selectively reduced by exposure to propanil. Journal of toxicology and environmental health 55, 107-120. 
Zhao, W., Schafer, R., and Barnett, J. B. (1999). Propanil affects transcriptional and posttranscriptional regulation of IL-2 expression in activated EL-4 cells. Toxicology and applied pharmacology 154, 153-159.

Zhao, W., Schafer, R., Cuff, C. F., Gandy, J., and Barnett, J. B. (1995). Changes in primary and secondary lymphoid organ T-cell subpopulations resulting from acute in vivo exposure to propanil. $J$ Toxicol Environ Health 46, 171-181. 
Email: miranda.hanson@nih.gov

Personal Info

Date of Birth: 12/17/81

Place of Birth: Wheeling, WV

\section{Education}

1996-2000: Mount de Chantal Academy, Wheeling, WV

2001-2005: Wheeling Jesuit University, B.S. in Biology

2005-2009: West Virginia University, School of Medicine, Immunology and Microbial Pathogenesis, PhD

\section{Employment History}

2003-2004: Organic Chemistry Lab, Wheeling Jesuit University, Teaching Assistant 2003-2005: Academic Resource Center, Wheeling Jesuit University, Writing Tutor 2004-2005: Academic Resource Center, Wheeling Jesuit University, Biology Tutor June-August 2004: Mary Babb Randolph Cancer Center, West Virginia University, Intern 2004-2005: Molecular Biology, Wheeling Jesuit University, Lab technician 2005-Present: Graduate Research Assistant, West Virginia University August-December 2007, August-December 2008: Medical Microbiology Lab, Teaching Assistant Sept 1, 2009-Present: National Cancer Institute, Frederick, MD, Post doc

\section{$\underline{\text { Awards }}$}

May 2005: Thacker Award for Performance in Biology, Wheeling Jesuit University May 2005: Haig Award for Scientific Research, Wheeling Jesuit University April 2008: Keynote Speaker, Research and Scholarship Day, Wheeling Jesuit University

\section{Presentations}

2004-2005: AFAP-110 as a potential binding partner of the $p 85 \alpha$ subunit of phosphatidylinositol kinase, WVINBRE Symposium, West Virginia University; Research Day at the Capitol, Charleston, WV; Research and Scholarship Symposium, Wheeling Jesuit University

December 2007: The effect of prenatal cadmium exposure on thymocyte development, Department of Microbiology, Immunology, and Cell Biology, West Virginia University

March 2008: Subcellular localization of the amide class herbicide 3,4-dichloropropionanilide (DCPA) in T cells, Society of Toxicology Conference, Seattle, Washington

October 2008: Immunotoxic effect of prenatal cadmium exposure on murine offspring, West Virginia COBRE/INBRE Conference, sponsored by NIH's National Center for Research Resources

March 2009: Immunotoxic effect of prenatal cadmium exposure on murine offspring, Society of Toxicology Conference, Baltimore, Maryland 


\section{$\underline{\text { Publications }}$}

Hanson, M.L., C. J. Peer, R.A. Brundage, P. Callery, K.M. Brundage, R. Schafer, S. Eremin, and J.B. Barnett. 2009. Subcellular localization of the amide class herbicide 3,4-dichloropropionanilide (DCPA) in T cells. Journal of toxicology and environmental health. In press

Hanson, M.L., K.M. Brundage, R. Schafer, J.C. Tou, and J. B. Barnett. 2009. Prenatal cadmium exposure dysregulates sonic hedgehog and Wnt/beta-catenin signaling in the thymus resulting in altered thymocyte development. Toxicology and applied pharmacology. In press

Hanson, M.L., K.M. Brundage, R. Schafer, R.A. Brundage, J. Tou and J. B. Barnett. 2009. Prenatal cadmium exposure alters postnatal immune cell development and function. In preparation

\section{Professional Memberships}

2007-Present: American Association of Immunologists (AAI)

2008-Present: Society of Toxicology (SOT)

2008-Present: American Medical Writers Association (AMWA)

\section{$\underline{\text { References }}$}

John Barnett, $\mathrm{PhD}$, advisor

jbarnett@hsc.wvu.edu

304-293-2649

Kathleen Brundage, PhD

kbrundage@hsc.wvu.edu

304-293-3551

Rosana Schafer, PhD

rschafer@hsc.wvu.edu

304-293-3104

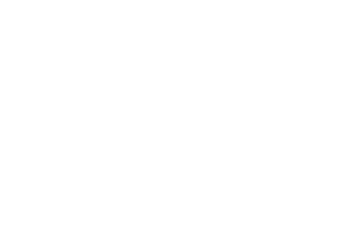

